\title{
Critical features of antigen-specific and allospecific recognition by cytotoxic T lymphocytes
}

\author{
Marc A. Frankenberry \\ West Virginia University
}

Follow this and additional works at: https://researchrepository.wvu.edu/etd

\section{Recommended Citation}

Frankenberry, Marc A., "Critical features of antigen-specific and allospecific recognition by cytotoxic T lymphocytes" (2004). Graduate Theses, Dissertations, and Problem Reports. 2099.

https://researchrepository.wvu.edu/etd/2099

This Dissertation is protected by copyright and/or related rights. It has been brought to you by the The Research Repository @ WVU with permission from the rights-holder(s). You are free to use this Dissertation in any way that is permitted by the copyright and related rights legislation that applies to your use. For other uses you must obtain permission from the rights-holder(s) directly, unless additional rights are indicated by a Creative Commons license in the record and/ or on the work itself. This Dissertation has been accepted for inclusion in WVU Graduate Theses, Dissertations, and Problem Reports collection by an authorized administrator of The Research Repository @ WVU.

For more information, please contact researchrepository@mail.wvu.edu. 
Critical Features of Antigen-Specific and Allospecific Recognition by Cytotoxic T Lymphocytes

\author{
Marc A. Frankenberry \\ Dissertation submitted to the \\ School of Medicine \\ at West Virginia University \\ in partial fulfillment of the requirements \\ for the degree of \\ Doctor of Philosophy \\ In \\ Microbiology, Immunology and Cell Biology \\ James M. Sheil, Ph.D., Committee Chair \\ Christopher F. Cuff, Ph.D. \\ Fred Minnear, Ph.D. \\ Rosana Schafer, Ph.D \\ William F. Tarry, M.D.
}

Department of Microbiology, Immunology, and Cell Biology

Morgantown, West Virginia
2004

Keywords: CTL, Antigen Presentation, MHC, T cell receptors, Alloreactive, Transplantation, T Lymphocytes 


\begin{abstract}
Critical Features of Antigen-Specific and Allospecific Recognition by Cytotoxic T Lymphocytes
\end{abstract}

Marc A. Frankenberry

In general, $\mathrm{CD} 8^{+} \mathrm{T}$ lymphocytes respond to a single class I MHC/peptide complex, a phenomenon known as "MHC self-restriction". We previously reported that $\mathrm{CD} 8^{+}$CTLs from C57BL/6 mice were restricted to both $\mathrm{H}-2 \mathrm{~K}^{\mathrm{b}}$ and $\mathrm{H}-2 \mathrm{D}^{\mathrm{b}}$ when responding to the horse cyt $c$-derived peptide, p41-49. In Part I of this dissertation, we examine structural features of $\mathrm{H}-2 \mathrm{~K}^{\mathrm{b}} / \mathrm{cyt} c$ and $\mathrm{H}-2 \mathrm{D}^{\mathrm{b}} / \mathrm{cyt} c$ complexes responsible for dual recognition. B6.H-4.1c, a representative cloned CTL, was induced by similar concentrations of native peptide added to either $\mathrm{H}-2 \mathrm{~K}^{\mathrm{b}}-$ or $\mathrm{H}-2 \mathrm{D}^{\mathrm{b}}$-expressing targets. Furthermore, the dissociation rates for both $\mathrm{H}-2 \mathrm{~K}^{\mathrm{b}} / \mathrm{cyt} c$ and $\mathrm{H}-2 \mathrm{D}^{\mathrm{b}} / \mathrm{cyt} c$ were comparable, but the optimal concentration of native peptide significantly increased for both $\mathrm{H}-2 \mathrm{~K}^{\mathrm{b}} / \mathrm{cyt} c$ and $\mathrm{H}-2 \mathrm{D}^{\mathrm{b}} / \mathrm{cyt} c$ in peptide competition assays. Based on computergenerated models, we proposed that the Pro ${ }^{44}-\mathrm{Gly}^{45}$ sequence was critical for B6.H-4.1c recognition and therefore constructed single Ala substitution analogues of cyt $c$, designated $\mathrm{p} 41-49 / 44 \mathrm{~A}$ and $\mathrm{p} 41-49 / 45 \mathrm{~A}$. Although $\mathrm{p} 41-49 / 44 \mathrm{~A}$ binds as well to $\mathrm{H}-2 \mathrm{~K}^{\mathrm{b}}$ and $\mathrm{H}-2 \mathrm{D}^{\mathrm{b}}$ as the native peptide, B6.H-4.1c recognition was abrogated. The $\mathrm{H}-2 \mathrm{~K} / \mathrm{p} 41$ 49/45A and $\mathrm{H}-2 \mathrm{D}^{\mathrm{b}} / \mathrm{p} 41-49 / 45 \mathrm{~A}$ complexes were lysed, but required significantly higher peptide concentrations than the native peptide. Molecular models for cyt $c, \mathrm{p} 41-49 / 44 \mathrm{~A}$ and p41-49/45A demonstrated that disrupting the $\mathrm{Pro}^{44}-\mathrm{Gly}^{45}$ sequence altered peptide configuration and inhibited B6.H-4.1c recognition. Nonspecific immunosuppressive agents are critical in clinical transplantation success, but cause generalized $\mathrm{T}$ cell inhibition and leave patients susceptible to elevated rates of infection and malignancy. In part II of this dissertation, we propose that removing allospecific CTLs that selectively expand in vitro will abrogate the alloreactive response. We show that five $\mathrm{CD} 8^{+}$ $\mathrm{V}_{\beta}$ families in bm19 anti-C57BL/6 cultures proliferate, but cytolytic analysis implicates only $\mathrm{V}_{\beta} 9^{+}$and $\mathrm{V}_{\beta} 12^{+} \mathrm{CTLs}$ as responders against $\mathrm{H}-2 \mathrm{~K}^{\mathrm{b}}$-expressing targets. Removal of both $\mathrm{V}_{\beta} 9 / 12^{+}$alloreactive CTLs did not affect the response to $\mathrm{K}^{\mathrm{b}}$-restricted antigens, nor to unrelated $\mathrm{H}-2^{\mathrm{d}}$ alloantigens. Depletion of both $\mathrm{V}_{\beta} 9 / 12^{+}$families significantly prolonged B6 allograft survival in bm19 mice. In addition, bm19 mice mounted a cellmediated response against $L$. monocytogenes despite removing $\mathrm{V}_{\beta} 9 / 12^{+}$CTLs. These studies demonstrate the synergistic effect of two $V_{\beta}$ families on alloreactivity and confirm that depletion of allograft-specific $\mathrm{V}_{\beta}{ }^{+}$CTLs prolong graft survival without disrupting host immune responsiveness. 


\section{ACKNOWLEDGMENTS}

I wish to express my appreciation and gratitude to my advisor, Dr. James M. Sheil, who has allowed me the opportunity to conduct research in his laboratory. I am grateful for the support and guidance you have provided me throughout the years and am indebted to you for the scientific training gained while in your laboratory.

To all the members of my committee, Dr. Christopher Cuff, Dr. Fred Minnear, Dr. William Tarry, Dr. Rosana Schafer, I thank you for the valuable discussions and excellent advise that you have given me concerning my project. I would also like to thank Dr. Robert Craig and the $\mathrm{MD} / \mathrm{PhD}$ oversight committee for their patience and guidance throughout my training.

Finally, I would like to thank my wife, Krista, my family and friends for their encouragement throughout my educational years. Without their dedicated and continuous support, this dissertation could not be a reality.

This dissertation is dedicated to my sister, Kristen Leah Frankenberry, who passed away in February of 2003. Her strength and persistence in overcoming adversity are a true inspiration and have helped to guide my pursuit of educational excellence. She will be missed, but never forgotten. 


\section{TABLE OF CONTENTS}

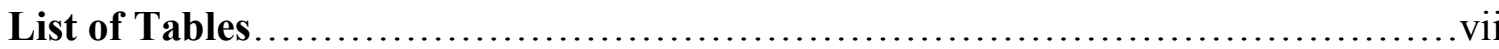

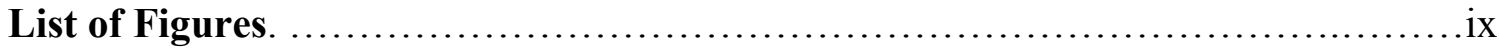

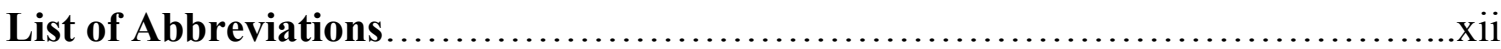

Chapter 1. Introduction and Review of Literature..............................

Overview of dissertation.........................................13

Figures and Figure Legends..................................... 15

References......................................................21

Chapter 2. A Cloned $\mathrm{CD}^{+}$Cytotoxic $\mathrm{T}$ Cell Displays both $\mathrm{K}^{\mathrm{b}}$ - and $\mathrm{D}^{\mathrm{b}}$-Restricted Recognition of the Horse Cytochrome $c$ Peptide, p41-49..............32

Abstract............................................................

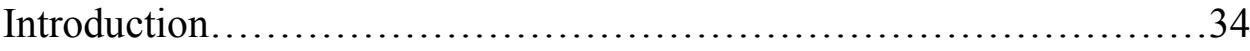

Materials and Methods.................................................. 38

Results......................................................44

Discussion....................................................51

Tables..............................................................

Figures and Figure Legends.....................................62

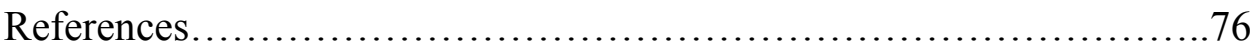

Chapter 3. Dual H-2K $\mathrm{K}^{\mathrm{b}}$ - and $\mathrm{H}-2 \mathrm{D}^{\mathrm{b}}$-Restricted Clonal CTL Recognition of a Horse Cytochrome $c$ Peptide is Dependent on a Critical Pro-Gly Sequence.......86

Abstract......................................................... 87

Introduction....................................................... 88 
Materials and Methods

Results......................................................... 98

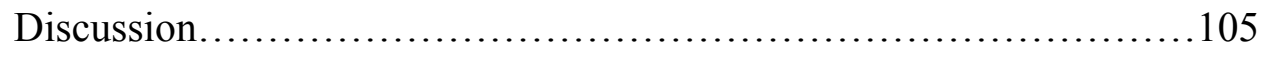

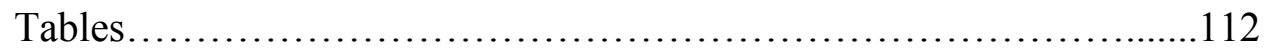

Figures and Figure Legends....................................... 115

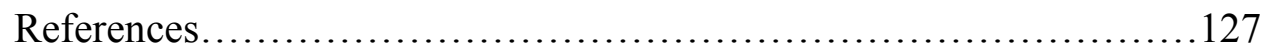

Chapter 4. Depletion of $\mathrm{V}_{\beta} 9^{+}$and $\mathrm{V}_{\beta} 12^{+}$CTLs in vitro abrogates the bm19 antiC57BL/6 alloreactive response without impairing antigen specific CTL reactivity ....................................................... 135

Abstract........................................................... 136

Introduction.................................................... 137

Materials and Methods............................................ 140

Results.......................................................... 146

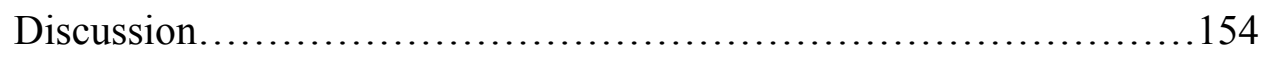

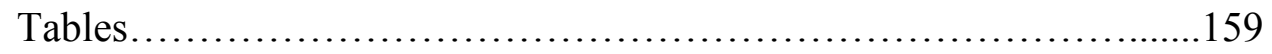

Figures and Figure Legends........................................ 161

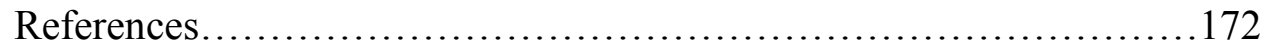

Chapter 5. Depletion of $\mathrm{V}_{\beta} 9^{+}$and $\mathrm{V}_{\beta} 12^{+} \mathrm{T}$ cells in bm19 mutant mice enhances the survival of C57BL/6 skin allografts without disrupting antigen-specific cell-mediated immunity............................................ 183

Abstract.......................................................... 184

Introduction.................................................... 185

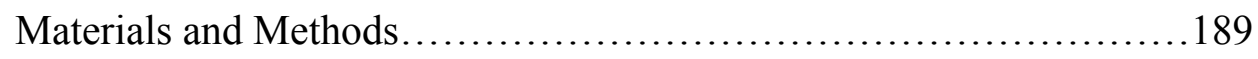


Results..................................................192

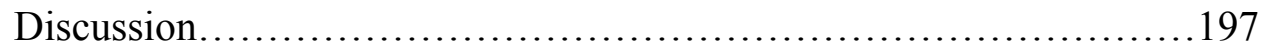

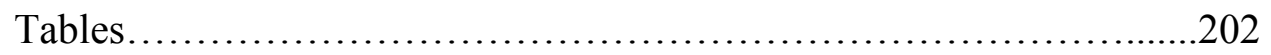

Figures and Figure Legends......................................203

References...............................................207

Chapter 6 General Discussion.........................................215

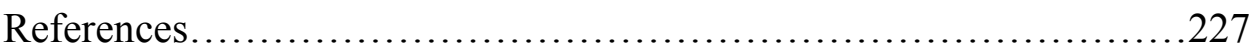

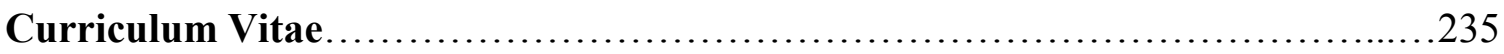




\section{LIST OF TABLES}

\section{CHAPTER 2}

The $\mathrm{K}^{\mathrm{b}}$-restricted peptide-binding motif for horse cyt $c$ p41-49 and MI B chain p7-15 residues............................................................. 58

The $\mathrm{D}^{\mathrm{b}}$-restricted peptide-binding motif for horse cyt $c$ p41-49 and MI B chain p7-15 residues

The competitor peptide, MI p7-15, significantly increases the concentration of horse cyt $c$ p41-49 required for Clone B6.H-4.1c recognition...........................60

Hydrogen bonds formed between $\mathrm{H}-2 \mathrm{~K}^{\mathrm{b}}$ or $\mathrm{H}-2 \mathrm{D}^{\mathrm{b}}$ and horse cyt $c \mathrm{p} 41-49 \ldots \ldots \ldots \ldots . .61$

\section{CHAPTER 3}

The $\mathrm{K}^{\mathrm{b}}$-restricted peptide-binding motif for native horse cyt $c \mathrm{p} 41-49$, peptide analogue p41-49/44A, peptide analogue p41-49/45A and MI B chain p7-15.............. 112

The $\mathrm{D}^{\mathrm{b}}$-restricted peptide-binding motif for native horse cyt $c$ p41-49, analogue p41-



Peptide competition assays reveal that significantly higher concentrations of native cyt $c$ and $\mathrm{p} 41-49 / 45 \mathrm{~A}$ analogue are required for Clone B6.H-4.1c recognition. .114

\section{CHAPTER 4}

Percent $\mathrm{CD}^{+} \mathrm{TCR} \mathrm{V}_{\beta}{ }^{+}$cells and lytic unit values for $3^{\circ}$ bm19 anti-B6 CTLs..........159

Percent $\mathrm{CD}^{+} \mathrm{TCR} \mathrm{V}_{\beta}{ }^{+}$cells and lytic unit values for $3^{\circ} \mathrm{bm} 19$ anti-B6 CTLs........... 160 


\section{CHAPTER 5}

Selective in vivo depletion of $\mathrm{TCR} \mathrm{V}_{\beta} 9^{+}, \mathrm{V}_{\beta} 12^{+}$and $\mathrm{V}_{\beta} 9 / 12^{+}$lymphocytes............202 


\section{LIST OF FIGURES}

\section{CHAPTER 1}

Comparative genetic maps of the human (HLA) and mouse $(\mathrm{H}-2)$ gene complexes.....15

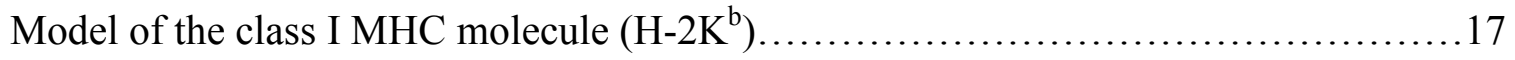

Class I MHC peptide processing and presentation................................19

\section{CHAPTER 2}

Optimum peptide concentrations are comparable for $\mathrm{H}-2 \mathrm{~K}^{\mathrm{b}}-$ and $\mathrm{H}-2 \mathrm{D}^{\mathrm{b}}$-restricted recognition of horse cyt $c$ p41-49 by Clone B6.H-4.1c.........................62

MI B chain p7-15 inhibits the response of Clone B6.H-4.1c to both $\mathrm{H}-2 \mathrm{~K}^{\mathrm{b}} / \mathrm{cyt} c \mathrm{p} 41-49$

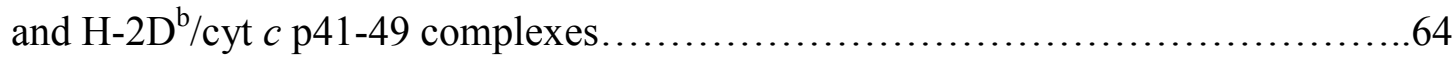

Horse cyt $c$ p41-49 and MI B chain p7-15 stabilizes the class I MHC molecules, H-2K $\mathrm{K}^{\mathrm{b}}$

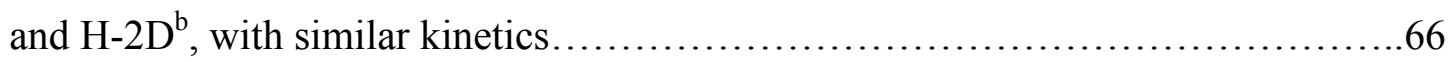

Horse cyt $c$ p41-49 (G-Q-A-P-G-F-T-Y-T) exhibits a constricted peptide configuration when complexed with $\mathrm{H}-2 \mathrm{~K}^{\mathrm{b}}$ and $\mathrm{H}-2 \mathrm{D}^{\mathrm{b}} \ldots$ .68

Pro $^{44}$ at peptide position $\mathrm{p} 4$ exhibited similar solvent accessibility and orientation when

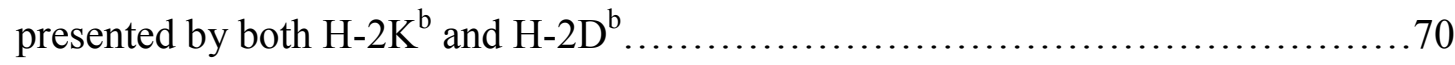

$\mathrm{Gln}^{42}$ at peptide position $\mathrm{p} 2$ anchors the amino terminus of horse cyt $c$ p41-49 in the B



Complex hydrogen bond networks are formed in the $\mathrm{F}$ pocket of $\mathrm{H}-2 \mathrm{~K}^{\mathrm{b}}$ to facilitate

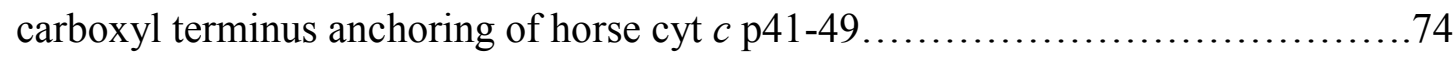




\section{CHAPTER 3}

Clone B6.H-4.1c recognizes the horse cyt $c$ analogue, p41-49/45A, but not analogue p41$49 / 44 \mathrm{~A}$

Native horse cyt $c$ p41-49 and the analogues, p41-49/44A and p41-49/45A, stabilizes $\mathrm{H}-2 \mathrm{~K}^{\mathrm{b}}$ and $\mathrm{H}-2 \mathrm{D}^{\mathrm{b}}$ molecules.

Significantly higher analogue p41-49/45A peptide concentrations are required for optimal target cell lysis by Clone B6.H-4.1c

Clone B6.H-4.1c responsiveness to horse cyt $c$ p41-49 is inhibited by the competitor peptides, MI B chain $\mathrm{p} 7-15$ and analogue $\mathrm{p} 41-49 / 44 \mathrm{~A}$......

Clone B6.H-4.1c responsiveness to analogue p41-49/45A is inhibited by the competitor

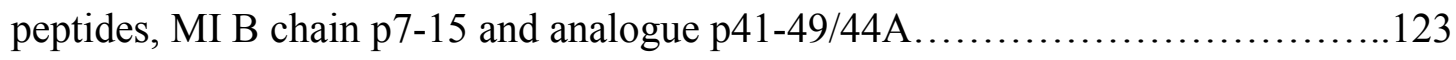

Essential TCR contacts with horse cyt $c$ p41-49 are disrupted by the single amino substitution (Pro ${ }^{44} \rightarrow$ Ala), thus abrogating Clone B6.H-4.1c recognition.

\section{CHAPTER 4}

Short- and long-term bm19 anti-B6 MLCs exhibit strong alloreactivity for $\mathrm{H}_{-} \mathrm{K}^{\mathrm{b}}$ bearing target cells.

In vitro expansion of bm19 anti-B6 CTL effectors occurs among five $\mathrm{V}_{\beta}$ families.....163

Depletion of $\mathrm{V}_{\beta} 8, \mathrm{~V}_{\beta} 14$ or $\mathrm{V}_{\beta} 17$ families from naïve bm19 splenic $\mathrm{T}$ cells yields fully alloreactive $3^{\circ} \mathrm{bm} 19$ anti-B6 CTL effectors

TCR $V_{\beta} 9$ and $V_{\beta} 12$ family depletion of naïve bm19 spleen cells abrogates the alloreactive response of $3^{\circ} \mathrm{bm} 19$ anti-B6 CTLs 
Antigen-specific and unrelated allospecific proliferation and function remain intact following the selective removal of TCR $\mathrm{V}_{\beta} 9 / 12^{+} \mathrm{T}$ cells..........................169

\section{CHAPTER 5}

Depletion of $\mathrm{V}_{\beta} 9^{+}, \mathrm{V}_{\beta} 12^{+}$and $\mathrm{V}_{\beta} 9 / 12^{+} \mathrm{T}$ cells in vivo significantly enhances the survival of B6 skin allografts transplanted onto bm19 mice..............................203

The selective removal of TCR $\mathrm{V}_{\beta} 9 / 12^{+} \mathrm{T}$ cells in vivo does not affect the cell-mediated

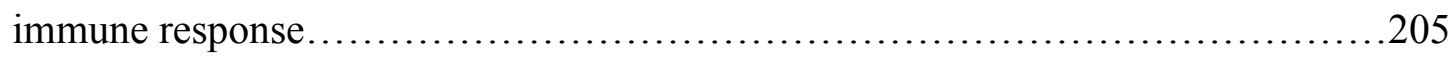




\section{LIST OF ABBREVIATIONS}

$\alpha-M M$

B6

BHI

bm19

BMT

Campath-1H

CD25

CDR

cyt $c$

DC

gB

GVHD

H

HSV-I

HTLV-1

LU

MI

OKT3

SEV-9

SP2/0

VSV-8 $\alpha$-methyl mannoside

C57BL/6

brain-heart infusion

B6.H-2 $2^{\text {bm19 }}$

bone marrow transplantation

Alemtuzumab

cluster of differentiation 25

complementarity-determining region

cytochrome $c$

dendritic cell

glycoprotein B

graft-versus-host disease

minor histocompatibility

herpes simplex virus-I

human T cell lymphotrophic virus-1

lytic unit

mouse insulin I B chain

muromonab-CD3

Sendai virus nucleoprotein peptide p324-332

SP2/0 AG.14

vesicular stomatitis virus-nucleoprotein peptide p52-59 


\section{CHAPTER 1}

\section{INTRODUCTION AND REVIEW OF LITERATURE}




\section{BACKGROUND AND SIGNIFICANCE}

\section{INTRODUCTION}

The cell-mediated immune response relies heavily on the ability of cytotoxic $\mathrm{T}$ lymphocytes (CTL) to recognize and eliminate antigen-presenting cells (APC) bearing foreign antigens. CTLs can respond to antigenic peptides presented by "self" class I major histocompatibility complex (MHC) molecules, denoted antigen-specific recognition, and to genetically disparate class I MHC/peptide complexes, denoted allospecific recognition. Antigen-specific recognition requires internal processing of foreign proteins, usually into 8-10 amino acid (AA) sequences, that are subsequently bound to the class I MHC molecule and presented on the cell surface (i.e., intracellular pathogens). Allospecific recognition traditionally refers to the CTL response against target cells that present foreign, or disparate, class I MHC molecules on their surface (i.e., transplanted tissues). In general, CTLs express the cluster of differentiation (CD) coreceptor, $\mathrm{CD} 8$, and interact, via the $\mathrm{T}$ cell receptor (TCR), with class I MHC/peptide complexes. Understanding the interactions of both antigen- and allospecific CTLs with the APC is essential to the future development of peptide-based vaccines and/or immunomodulatory monoclonal antibody $(\mathrm{mAb})$ therapies.

The following sections will provide a brief review of the current knowledge pertaining to the class I MHC molecule, antigen processing and presentation, and the interactions of the $\mathrm{MHC} /$ peptide/TCR trimolecular complex, as well as the history of transplant research and the direct and indirect pathways of allograft rejection. 


\section{The Class I MHC}

The mouse MHC molecule is encoded by the H-2 MHC gene complex and is located on the short arm of chromosome 17, while the human leukocyte antigen (HLA) molecule is encoded by the HLA gene complex and is located on the short arm of chromosome 6. Although the mouse H-2 complex was discovered first, the human HLA sequence was the first to be determined, in part due to the progress of the Human Genome Project $(1,2)$. In humans, the class I HLA genes (distal to the centromere) and class II genes (proximal to the centromere) are separated by the class III region (Figure 1). The mouse class I H-2 genes are arranged within $\mathrm{K}$ (proximal to the centromere) and D-L (distal to the centromere) regions and separated by class II and III genes (Figure 1).

For the purpose of this dissertation, we will focus on the murine class I H-2 genes. The class I H-2 region is further subdivided into five gene regions [H2-K, -D, -Q, -T, and -M] and encode the class Ia molecules, H-2K, H-2D and H-2L, and the nonclassical class Ib molecules, Qa-1, Qa-2, Qb-1, Q10, TL, M3 and CD1d $(3,4)$. There are approximately 30 functional murine class I genes, but this number does vary among mouse haplotypes (5). The H-2 Ia molecules are highly polymorphic, expressed ubiquitously and present antigenic peptides to $\mathrm{CD}^{+} \mathrm{CTLs}$, while $\mathrm{Ib}$ molecules are moderately polymorphic, expressed in various different tissue types and present antigens to both TCR $\alpha \beta$ - and $\gamma \delta$ bearing effector cells (4).

Class I MHC molecules (Figure 2) are expressed on the cell surface of virtually all nucleated cells and are composed of a $45 \mathrm{kD}$ heavy chain and a $12 \mathrm{kD}$ noncovalently associated light chain, denoted $\beta_{2}$-microglobulin $\left(\beta_{2} \mathrm{~m}\right)(6)$. The heavy chain is a glycosylated transmembrane protein with both intracellular and extracellular components. 
The extracellular portion consists of three domains $(\alpha 1, \alpha 2$, and $\alpha 3)$ that contain approximately 90 AA each. The amino terminal domains ( $\alpha 1$ and $\alpha 2)$ form the peptidebinding groove, consisting of eight strands of antiparallel $\beta$-pleated sheets that support two $\alpha$ helices aligned in an antiparallel orientation. The membrane proximal domain ( $\alpha 3)$ forms an "immunoglobulin-like" molecule, with folded regions similar to the Fc portion of immunoglobulin (Ig) molecules, which support the $\alpha 1$ and $\alpha 2$ domains (7). The extracellular components are anchored to the cell surface by a 23 AA hydrophobic transmembrane region (8). The intracellular portion is composed of $37 \mathrm{AA}$, most of which are hydrophilic. The $\beta_{2} \mathrm{~m}$ molecule is encoded by the $B 2 \mathrm{~m}$ gene, located on chromosome 2, and contains approximately 99AA (9). This $12 \mathrm{kD}$ light chain is an "immunoglobulin-like" non-glycosylated protein that associates noncovalently with the class I MHC heavy chain, assisting the $\alpha 3$ domain in supporting the peptide-binding groove (10-12). The formation of a stable class I MHC $/ \beta_{2} \mathrm{~m}$ complex is required for peptide binding in the lumen of the endoplasmic reticulum (ER).

\section{Class I MHC Antigen Processing and Presentation}

The primary source of antigenic peptides that bind to the class I MHC molecule are derived from newly synthesized proteins in the cytosol (13-15). Unfolded proteins and polypeptides within the cytosol are modified, by covalently linking the cofactor ubiquitin, before they can be degraded by the protease, proteasome (16) (Figure 3). The proteasome is a multifactorial protease that contains both catalytic subunits and proteolytic activities that can be activated by interferon- $\gamma$ (IFN- $\gamma$ ) and PA28 (17). Proteasomes degrade proteins to oligopeptides, ranging from 4 to 20 AA residues, and 
are responsible for generating the $\mathrm{C}$-terminus of antigenic peptides. The $\mathrm{N}$-terminus is subsequently modified and, in some cases, extended by a second set of proteases, termed endopeptidases and aminopeptidases (18).

The bulk of oligopeptides generated by the proteasome are further degraded into AAs by the endopeptidases and aminopeptidases, but a fraction of these peptides are translocated into the lumen of the ER by the transported associated with antigen processing (TAP) (13). TAP is composed of two subunits, TAP1 and TAP2, encoded within the class II MHC region. TAP is a member of the ATP-binding cassette (ABC) family of transporters and requires ATP for its transport activity. Peptides, ranging from 8 to 13 residues, bind to TAP, inducing a conformational change in the TAP/peptide complex. This conformational change induces ATP hydrolysis, pore opening and the release of the peptide into the lumen of the ER (14).

Several studies involving TAP-deficient cells have demonstrated that TAP is the major supplier of peptides to the ER lumen (19-21). TAP-deficient cells fail to assemble class I MHC/peptide complexes in the ER and therefore have severe defects in the surface expression of MHC molecules $(22,23)$.

Newly synthesized class I MHC heavy chains ( $\alpha 1, \alpha 2$ and $\alpha 3)$ in the ER lumen bind to the $88 \mathrm{kD}$ membrane-bound chaperone protein, calnexin. Calnexin induces a partially folded configuration in the $\mathrm{MHC}$ molecule that allows noncovalent binding of the $\beta_{2} \mathrm{~m}$ molecule. After $\beta_{2} \mathrm{~m}$ association, calnexin is replaced with a second chaperone, denoted calreticulin, and the $\mathrm{MHC} / \beta_{2} \mathrm{~m} /$ calreticulin complex moves to and associates with TAP, tapasin and the ER-resident protein, ERp57 (24,25). This large protein complex is called the class I MHC peptide-loading complex. 
The N-terminus of tapasin interacts with the $\alpha 2$ and $\alpha 3$ domains of the class I heavy chains, while the C-terminus of tapasin binds to TAP $(24,26,27)$. Tapasin is encoded in the class II MHC region and is involved in MHC peptide loading. Like TAPdeficient cells, tapasin-deficient cells express few cell surface class I molecules and exhibit defective antigen presentation $(25,28,29)$. Cresswell and coworkers (30) have demonstrated that the addition of soluble tapasin proteins to tapasin-deficient cells increases the stability of the TAP, enhances peptide transport capacity and restores stable $\mathrm{MHC} /$ peptide surface expression.

The ER-resident protein, ERp57, is covalently linked to tapasin by a disulfide bond and facilitates the complete oxidation of the class I heavy chains. Mutations in the tapasin molecule that prevent ERp57/tapasin interactions not only abrogate MHC oxidation, but also inhibit peptide loading (31). Thus, the formation of the complete class I MHC peptide-loading complex is required to maintain efficient peptide loading.

Class I MHC $/ \beta_{2} \mathrm{~m}$ complexes are released from the class I MHC peptide-loading complex after peptide translocation into the ER by TAP. The incorporation of peptide into the peptide-binding groove induces the release of the MHC/peptide complex from the class I MHC peptide-loading complex, but the MHC/peptide complex re-associates with calnexin and persists in the ER for a period of time before emerging on the cell surface (32). 


\section{The $\alpha \beta$ TCR Structure and TCR/MHC/Peptide Interactions}

Immunoprecipitation of the TCR from T cell clones revealed an 85,000 to 90,000 molecular weight (MW) disulfide-bonded heterodimer structure that consists of two 45,0000 to 50,000 MW glycosylated subunits, termed $\alpha$ and $\beta$ (33). The $\alpha$ polypeptide gene segment contains a leader $(\mathrm{L})$, variable $(\mathrm{V})$, joining $(\mathrm{J})$ and constant $(\mathrm{C})$ region, while the $\beta$ heterodimer contains all of $\alpha$ polypeptide regions plus an additional diversity (D) region distal to the $\mathrm{V}$ region and proximal to the $\mathrm{J}$ region. Thus, the $\alpha$ chain forms by a single in-frame rearrangement (V-J) and the $\beta$ chain requires two successive rearrangements (V-D-J) before joining the $\mathrm{C}$ region $(34,35)$. The $\alpha \beta$ TCR consists of an $\mathrm{N}$-terminal $\mathrm{V}$ region (distal to the cell surface) and a $\mathrm{C}$-terminal $\mathrm{C}$ region (membrane bound). Homologous to Ig complementary-determining regions (CDR), the $\alpha \beta$ TCR displays three CDR regions that protrude from the distal ends of both the $V_{\beta}$ and $V_{\alpha}$ domains that contact the MHC/peptide complex (36-39). CDR1 and CDR2 are encoded within the $\mathrm{V}$ region and CDR3 results from $\mathrm{V}-\mathrm{J}$ rearrangements in the $\alpha$ chain and the $\mathrm{V}$ D-J rearrangements in the $\beta$ chain (40).

Initial attempts, by this lab in collaboration with Nathenson, to determine the interactions between the TCR and MHC/peptide complex analyzed a large panel of alloreactive CTLs for their reactivity on a diverse group of $\mathrm{H}-2 \mathrm{~K}^{\mathrm{b}}$ mutant cell lines (41). These studies revealed that the TCR was aligned over the distal surface of the $\mathrm{H}-2 \mathrm{~K}^{\mathrm{b}} /$ peptide complex, parallel to the $\beta$-pleated sheet of the $\alpha 1$ and $\alpha 2$ domains. Similarly, Janeway and others reported that the TCR $\mathrm{V}_{\alpha}$ domain made contact with the 
peptide $\mathrm{N}$-terminus while the $\mathrm{V}_{\beta}$ domain made contact with the $\mathrm{C}$-terminus on the class II MHC/peptide complex (42).

By determining the $\mathrm{x}$-ray crystal structure of the $2 \mathrm{C} T \mathrm{TCR} / \mathrm{H}-2 \mathrm{~K}^{\mathrm{b}} / \mathrm{dEV} 8$ trimolecular complex, Garcia and coworkers initially described the TCR/MHC/peptide interaction between the $\mathrm{T}$ cell clone, $2 \mathrm{C}$, and the $\mathrm{H}-2 \mathrm{~K}^{\mathrm{b}} / \mathrm{dEV} 8$ complex (37). This group demonstrated that the $2 \mathrm{C} \mathrm{V}_{\alpha} \mathrm{CDR} 1$ and CDR2 domains are positioned over the N-terminus of the dEV8 peptide, while the $\mathrm{V}_{\beta} \mathrm{CDR} 1$ and CDR2 domains are positioned over the C-terminus of dEV8. Interestingly, the $\mathrm{V}_{\alpha}$ and $\mathrm{V}_{\beta} \mathrm{CDR} 3$ domain associates with the central portion of the peptide, directly between the $\alpha$ helices of $H-2 K^{b}$ (37). Several other investigators have since described similar results for human (36) and unrelated murine TCR/MHC/peptide crystal structures $(38,39)$. Thus, the major peptide residues that interact with the diverse CDR3 domain can be predicted, with some degree of confidence, to lie within the central peptide region. This observation is important since it may prove particular useful in the development of peptide-based vaccines or in antigenic mimicry.

\section{A Brief History of Transplant Research}

The earliest tissue transplantation recorded, believed to be performed as early as 700 B.C., was by a Hindu surgeon who used a flap of skin from the patient's forehead to cover and repair the patient's amputated nose (Woodruff, 1960). By the late 1800s skin grafting became an accepted practice, but the transplantation of internal organs was not successful until vascular anastomosis techniques were developed in the 1900s. Carrel reported the first allotransplantation (in 1908) of both kidneys in a series of nine cats, in 
which urine output was maintained for up to 25 days but ultimately resulted in the death of all nine cats (Carrel, 1908 p98). The first human renal transplantation was reported by a Russian surgeon in 1936, but its success was hindered by mismatched blood types and resulted in minimal renal function before the patient's death (Woodruff, 1960). Almost two decades later, in 1952, the first successful renal transplant was performed between identical twins (43). Currently, transplanted organs include the: cornea, kidney, liver, heart, lung, pancreatic islet cells and hematopoietic cells.

After extensively studying tumor engraftment in inbred mice strains, Clarence Little determined that transplantation immunology is governed by the "five laws of transplantation" (Little, 1924; p75).

1. Transplants within inbred strains will succeed.

2. Transplants between inbred strains will fail.

3. Transplants from a member of an inbred parental strain to an $F_{1}$ offspring will succeed but those in the reverse direction will fail.

4. Transplants from $F_{2}$ and all subsequent generations to $F_{1}$ animals will succeed.

5. Transplants from inbred parental strains to the $F_{2}$ generation will usually, but not always, fail.

Although these "laws" appear confusing, the basic principle is that the graft recipient will reject any transplanted tissue that expresses a tissue antigen (now known to be the MHC) that is not expressed by the recipient.

Currently, the prevention of transplantation rejection requires that the recipient receive exogenous combinations of immunosuppressive agents, such as cyclosporine, tacrolimus, sirolimus, rapamycin, mycophenolate, azathioprine and steroids. These nonspecific immunosuppressive agents can be used to inhibit lymphocyte gene transcription (i.e., cyclosporine), cytokine signaling (i.e., rapamycin), or nucleotide synthesis (i.e., mycophenolate). More specifically, cyclosporine binds to and blocks the 
phosphatase activity of calcineurin, the intracellular signaling protein essential for IL-2 transcription (44). In a separate manner, tacrolimus, a macrolide, binds to the intracellular FK506-binding protein and the tacrolimus/FK506 complex in turn inactivates calcineurin. Sirolimus is a macrocyclic triene antibiotic that is structurally similar to FK506 and thus, by binding to calcineurin, interrupts IL-2 synthesis (45). Rapamycin also associates with FK506, but does not affect calcineurin, instead it blocks $\mathrm{T}$ cell proliferation by inhibiting the signaling transduction of IL-2 (45). The active metabolite of mycophenolate mofetil, mycophenolic acid, inhibits purine synthesis, but this immunosuppressive agent is sparingly used since it has been shown to cause significant leukopenia (46). Likewise, azathioprine, an analogue of 6-mercaptopurine, is a purine synthesis inhibitor and thus blocks cellular division. $\mathrm{T}$ cell proliferation and cytokine gene transcription are disrupted by the use of corticosteroids (46).

Several experimental immunosuppressive agents are considered potential adjuncts to traditional exogenous therapies. Brinkmann and coworkers have demonstrated that the administration of FTY720 reduces the total number of circulating lymphocytes, increases lymphocyte homing to lymphoid tissues (lymph nodes and Peyer's patches) and prevents the entry of lymphocytes into the tissue graft $(47,48)$. Other experimental drugs of interest include 15-deoxysperqualin, which prevents $\mathrm{T}$ and $\mathrm{B}$ cells differentiation into effector cells, and leflunomide, which prevents lymphocyte proliferation by inhibiting pyrimidine synthesis and tyrosine kinase activation.

The use of antibodies $(\mathrm{Ab})$ specific for recipient $\mathrm{T}$ cells, the IL-2 receptor (IL$2 \mathrm{R}$ ), and a variety of transplant rejection markers have recently been implicated as a potential adjunct to traditional immunosuppressive agents. The immunomodulating 
agent, OKT3 is a mouse-derived $\mathrm{mAb}$ directed against the human form of the CD3 region and has been used successfully to reverse acute rejection episodes when added to traditional immunosuppressive agents (49). Campath-1H is a humanized mAb directed against the CD52 antigen, a marker present on $>95 \%$ of circulating lymphocytes, and causes the reduction of the total number of circulating T cells, B cells, NK cells and monocytes. Several immunomodulator agents are directed against the IL-2R $\alpha$ chain (CD25), and have been shown to reduce allograft refection in renal transplant recipients by $49 \%$ six months after transplantation $(50,51)$.

The transplantation of organs is now a relatively common occurrence in the United States, with approximately 10,000 kidney transplants performed each year. Patient survival 1 year after renal transplantation is better than $90 \%$ and kidney function at 1 year exceeds $85 \%$ (52). Unfortunately, the conditional half-life of renal transplants (the number of years at which half of transplanted kidneys are rejected compared to those functioning at one year) remains at less than 10 years. The 1 year survival of hepatic transplantation is approximately $75 \%$, probably due to the finding that this organ is resistant to Ab-mediated rejection $(53,54)$. Heart and lung transplantations are relatively new arrivals to clinical transplantation, but have been highly successful, with 1 year survival rates that exceed $80 \%$. These patients, however, exhibit organ specific complications, with cardiac patients developing atherosclerotic disease and lung patients developing bronchiolitis obliterans, as manifestations of chronic rejection. Pancreas and islet cell transplantations have demonstrated a success rate of approximately $80 \%$ when patients receive sirolimus, tacrolimus and anti-IL-2R (55). The current success rates are dependent on the lifelong use of immunosuppressive agents and increase the risk of 
infection and cancer development. Therefore, to prevent these complications and increase patient quality of life it is important that other, more specific, immunosuppressive agents are researched and developed in the future.

\section{Direct versus Indirect Allorecognition}

The immunological response of the recipient immune system to donor MHC molecules is the primary hindrance to the success of allo-transplantation $(56,57)$. The recognition of allogeneic $\mathrm{MHC}$ molecules on the transplanted graft elicits a strong alloreactive reaction, resulting in the destruction of donor cells and hence graft rejection. Class I allorecognition is traditionally considered to be the recognition of foreign MHC/peptide complexes presented on the cell surface of donor cells by $\mathrm{CD} 8^{+} \mathrm{CTLs}$ of the recipient's immune system (direct allorecognition). An alternative mechanism was, however, suggested in 1982 by Lechler and Batchelor in which the donor transplant MHC molecules were processed and presented as peptides by recipient APCs (indirect allorecognition) (58). Since then, several investigators have furthered this proposal in human, mouse and rat models (59-64). Thus, allorecognition can occur via two pathways, the direct and the indirect allorecognition pathways. The alloreactive CTLs that utilize the direct pathway are characterized by a high precursor frequency $(>90 \%)$ and a diverse TCR specificity, while CTLs that utilize the indirect pathway recognize processed forms of donor antigens associated with recipient MHC molecules and can be

defined by a limited $V_{\beta}$ gene usage and CTLs that are directed against a single peptide determinant presented by the donor MHC $(59,65,66)$. Interestingly, it has been suggested that although the use of nonspecific immunosuppressive agents is capable of inhibiting 
the acute rejection phase of direct recognition, these agents are not able to prevent chronic rejection by indirect allorecognition $(67,68)$. These observations suggest that acute allograft rejection is the result of direct allorecognition and that chronic rejection is the consequence of indirect allorecognition.

\section{Dissertation Overview}

This dissertation examines two related areas of immunology: i) antigen-specific recognition of a single peptide, horse cytochrome $c$ (cyt $c$ ) p41-49, in the context of two separate class I MHC molecules, $\mathrm{H}-2 \mathrm{~K}^{\mathrm{b}}$ and $\mathrm{H}-2 \mathrm{D}^{\mathrm{b}}$, and ii) allospecific recognition of the parental strain, C57BL/6, class I MHC/peptide complex by the $\mathrm{H}-2 \mathrm{~K}^{\mathrm{bm} 19}$ mutant mouse. In Chapter 2, we propose that the dual recognition of $\mathrm{H}-2 \mathrm{~K}^{\mathrm{b}} / \mathrm{cyt} c \mathrm{p} 41-49$ and $\mathrm{H}-$ $2 \mathrm{D}^{\mathrm{b}} /$ cyt $c$ p41-49 complexes by a group of CTLs, represented by Clone B6.H-4.1c requires comparable MHC/peptide comformations. Clone B6.H-4.1c was induced by in vitro priming with a tryptic digest of denatured cyt $c$ and has previously been shown to respond to both $\mathrm{H}-2 \mathrm{~K}^{\mathrm{b}} / \mathrm{cyt} c \mathrm{p} 41-49$ and $\mathrm{H}-2 \mathrm{D}^{\mathrm{b}} / \mathrm{cyt} c \mathrm{p} 41-49$ complexes (69). This chapter defines the minimal cyt $c$ p41-49 peptide concentration required for recognition by Clone B6.H-4.1c and demonstrates that cyt $c$ p41-49 binds to and stabilizes both $\mathrm{H}-2 \mathrm{~K}^{\mathrm{b}}$ and $\mathrm{H}-2 \mathrm{D}^{\mathrm{b}}$ molecules. Furthermore, peptide competition experiments show that Clone B6.H-4.1c dual-restricted recognition of $\mathrm{H}-2 \mathrm{~K}^{\mathrm{b}} / \mathrm{cyt} c$ p41-49 and $\mathrm{H}-2 \mathrm{D}^{\mathrm{b}} / \mathrm{cyt} c$ p41-49 complexes are comparable. This chapter also includes computer-generated molecular models to evaluate potential peptide residues involved in interacting with the TCR of Clone B6.H-4.1c. In Chapter 3, we propose that the $\mathrm{Pro}^{44}-\mathrm{Gly}^{45}$ induced type II $\beta$ bend is the critical peptide sequence involved in Clone B6.H-4.1c recognition of 
$\mathrm{H}-2 \mathrm{~K}^{\mathrm{b}} / \mathrm{cyt} c \mathrm{p} 41-49$ and $\mathrm{H}-2 \mathrm{D}^{\mathrm{b}} / \mathrm{cyt} c \mathrm{p} 41-49$ complexes. This chapter utilizes horse cyt $c$ analogues, constructed by single Ala substitutions at peptide positions p4 $\left(\mathrm{Pro}^{44} \rightarrow \mathrm{Ala}\right)$ and $\mathrm{p} 5\left(\mathrm{Gly}^{45} \rightarrow \mathrm{Ala}\right)$, designated $\mathrm{p} 41-49 / 44 \mathrm{~A}$ and $\mathrm{p} 41-49 / 45 \mathrm{~A}$, to evaluate $\mathrm{H}-2 \mathrm{~K}^{\mathrm{b}}$ and $\mathrm{H}-2 \mathrm{D}^{\mathrm{b}}$ stabilization and cytolytic activity of Clone B6.H-4.1c. This chapter also uses computer-generated models of the native cyt c p41-49, and analogues p41-49/44A and p41-49/45A to demonstrate alterations in the Pro $^{44}-\mathrm{Gly}^{45}$ type II $\beta$ bend influence the distribution of peptide R-group surface availability, that disrupt interactions with the TCR of Clone B6.H-4.1c.

In addition to identifying crucial components of the antigen-specific response of Clone B6.H-4.1c, this dissertation also addresses the critical features of allospecific recognition for closely related $\mathrm{H}-2 \mathrm{~K}^{\mathrm{b}}$ mutant strains. In Chapter 4 , we propose that alloreactive CTLs from the B6.H-2 ${ }^{\text {bm19 }}$ (bm19) (70) will undergo selective expansion following in vitro stimulation with irradiated C57BL/6 (B6) splenocytes (71), and that the removal of these bm19 anti-B6 splenocytes will abrogate the alloreactive response. This chapter demonstrates that bm19 anti-B6 mixed lymphocyte cultures (MLC) preferentially express TCR $\mathrm{V}_{\beta}{ }^{+}$families and that the depletion of specific bm19 $\mathrm{V}_{\beta}{ }^{+}$CTLs abrogates $\mathrm{H}-2 \mathrm{~K}^{\mathrm{b}}$-expressing target cell cytolysis. In addition, Chapter 4 shows that the depletion of $\mathrm{H}-2 \mathrm{~K}^{\mathrm{b}}$-specific CTLs does not inhibit unrelated allospecific or antigen-specific recognition. In Chapter 5, we propose that the in vivo depletion of $\mathrm{H}-2 \mathrm{~K}^{\mathrm{b}}$-specific CTLs (described in Chapter 4) will inhibit bm19 rejection of B6 skin allografts. This chapter characterizes the prolonged survival of $B 6$ skin allografts when TCR $V_{\beta} T$ cells are selectively removed from bm19 mice. The ability of $b m 19 \mathrm{~V}_{\beta}{ }^{-}$mice to mount a T-cell mediated response is also evaluated in this chapter. 


\section{FIGURES AND FIGURE LEGENDS}

Fig. 1 Comparative genetic maps of the human (HLA) and mouse (H-2) gene complexes.

The human HLA complex (chromosome 6) is shown on the top, with the mouse H-2 complex (chromosome 17) below. MHC-I, MHC-II and MHC-III regions are represented below the short arm of the chromosome. This map is not complete nor drawn to scale and is derived from multiple sources (72-75). 


\section{Human}

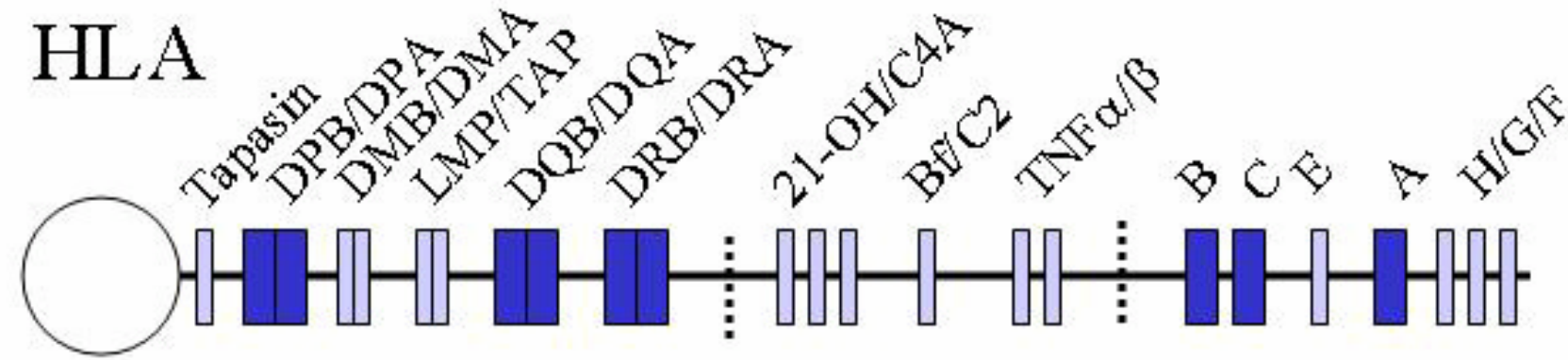

MHC-II Region

$(1000 \mathrm{~kb})$
MHC-III Region MHC-I Region

$(1000 \mathrm{~kb})$

$(2000 \mathrm{~kb})$

\section{Mouse}

$\mathrm{H}-2$

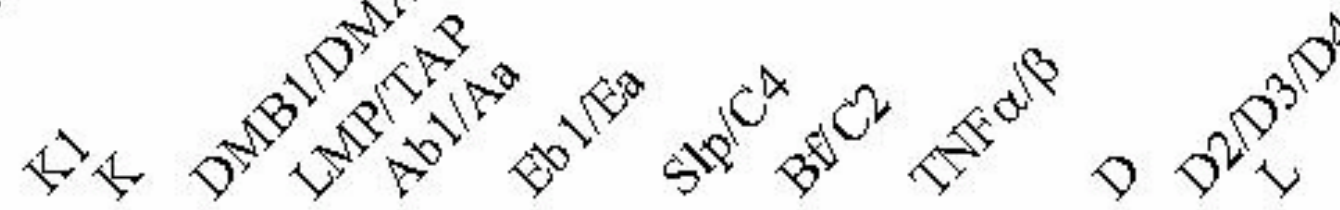

OH:H

MHC-I Region MHC-II Region MHC-III Region MHC-I Region
$(18.4 \mathrm{cM})$
$(18.7 \mathrm{cM})$
(19.1 cM)
$(20.1 \mathrm{cM})$ 


\section{Fig. 2 Model of the class I MHC molecule $\left(\mathbf{H}-2 K^{b}\right)$.}

Side-view of the $\mathrm{H}-2 \mathrm{~K}^{\mathrm{b}}$ class I MHC molecule, demonstrating the three extracellular domains of the $\alpha$ heavy chain (purple) and the $\beta_{2}$ m (red). The peptide binding groove, located on the distal surface of the molecule, is shown at the top of the figure. 


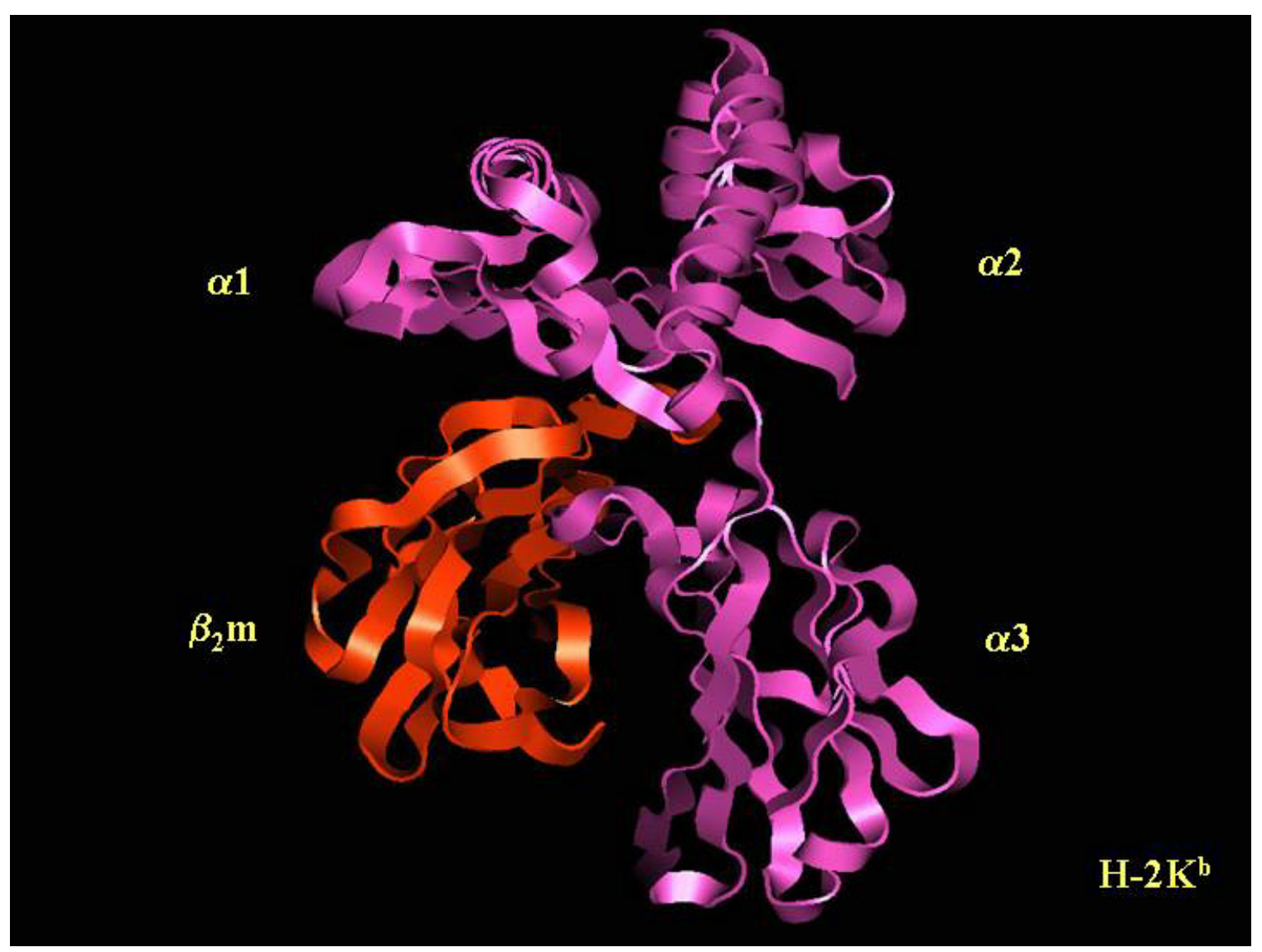




\section{Fig. 3 Class I MHC peptide processing and presentation.}

Newly synthesized proteins are degraded into 4 to 20 AA peptides by the proteasome and further modified by aminopeptidases in the cytosol. These peptides are subsequently bound by TAP and transported into the lumen of the ER. Immediately after synthesis, class I MHC heavy chains bind with the chaperone, calnexin, in the ER lumen. The binding of $\beta_{2} \mathrm{~m}$ to the $\mathrm{MHC}$ heavy chain facilitates the release of calnexin and the association of the $\mathrm{MHC} / \beta_{2} \mathrm{~m}$ with calreticulin. The class I heterodimer joins the class I peptide-loading complex - TAP, tapasin and Erp57 - and binds an 8-10 AA peptide. After peptide incorporation, the $\mathrm{MHC} / \beta_{2} \mathrm{~m} /$ peptide complex re-associates with calnexin prior to being transported to the Golgi apparatus and finally arrives on the cell surface.

\section{Legend}

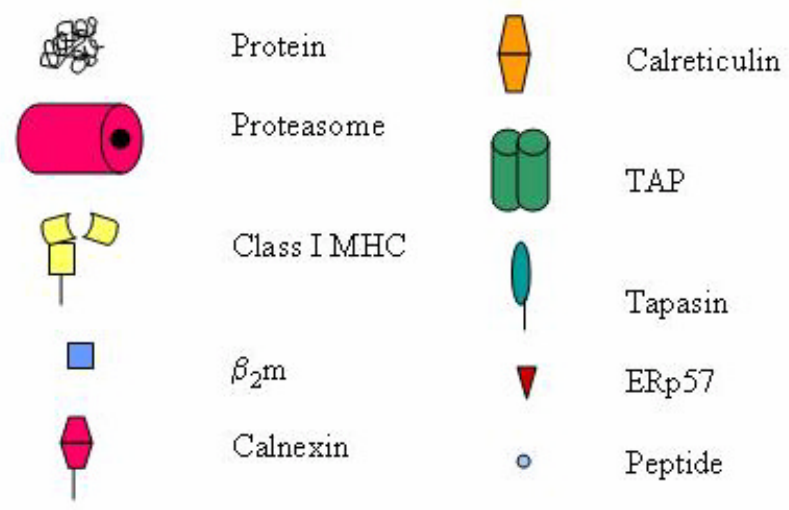




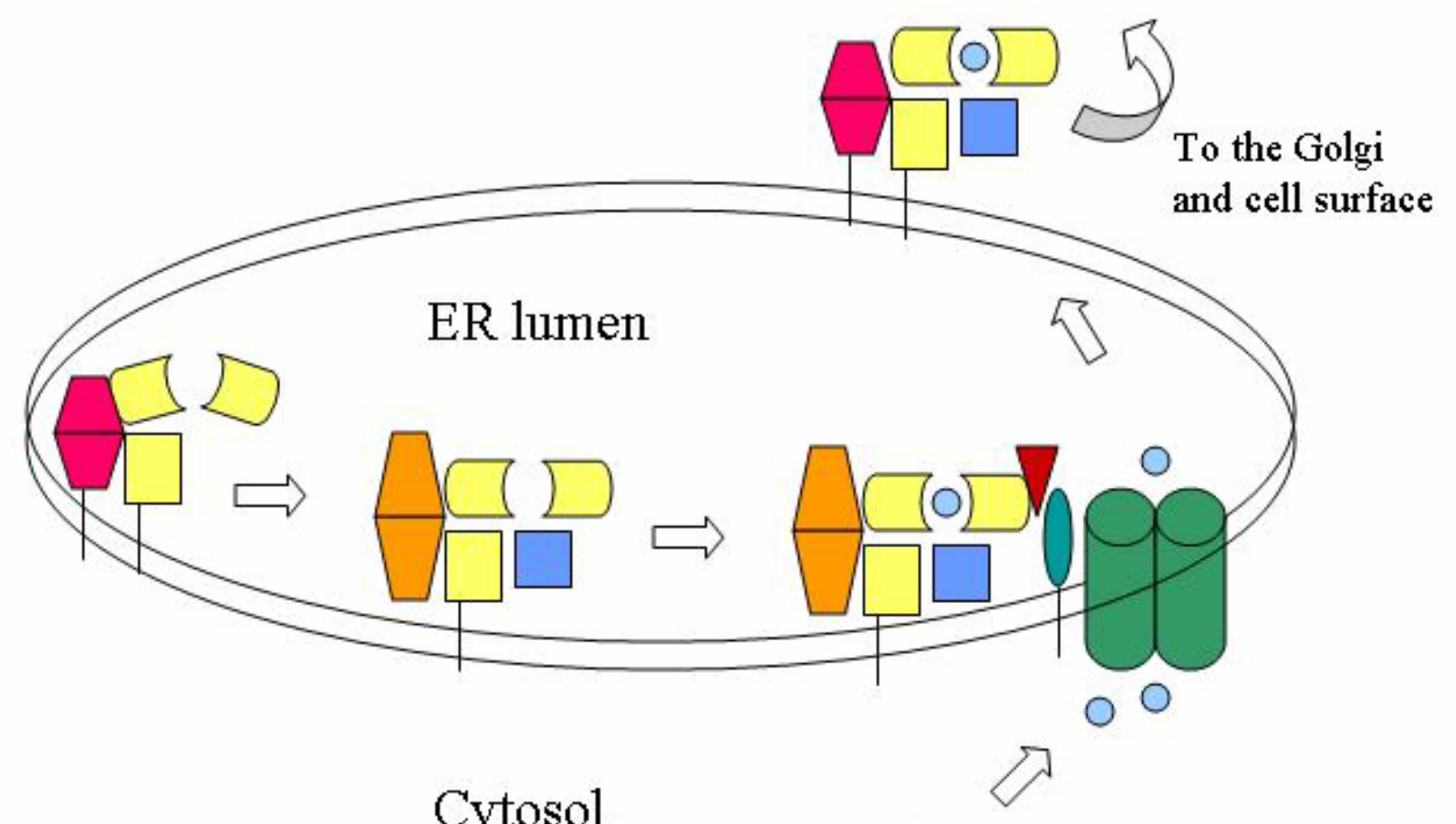

Cytosol

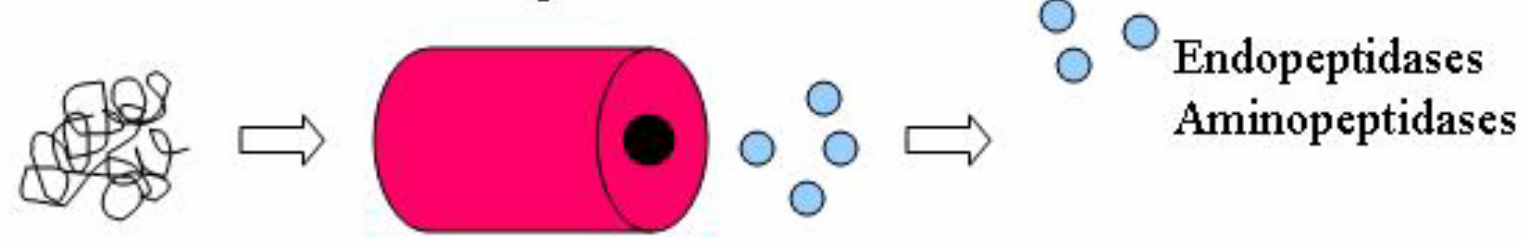




\section{REFERENCES}

1. 1999. Complete sequence and gene map of a human major histocompatibility complex. The MHC sequencing consortium. Nature 401:921-923.

2. SNELL, G. D. and G. F. HIGGINS. 1951. Alleles at the histocompatibility-2 locus in the mouse as determined by tumor transplantation. Genetics 36:306-310.

3. Hughes, A. L., M. Yeager, A. E. Ten Elshof, and M. J. Chorney. 1999. A new taxonomy of mammalian MHC class I molecules. Immunol.Today 20:22-26.

4. Stroynowski, I. and K. F. Lindahl. 1994. Antigen presentation by non-classical class I molecules. Curr.Opin.Immunol. 6:38-44.

5. Kumanovics, A., A. Madan, S. Qin, L. Rowen, L. Hood, and L. K. Fischer. 2002. QUOD ERAT FACIENDUM: sequence analysis of the H2-D and H2-Q regions of 129/SvJ mice. Immunogenetics 54:479-489.

6. Jones, E. Y. 1997. MHC class I and class II structures. Curr.Opin.Immunol. 9:75-79.

7. Tragardh, L., L. Rask, K. Wiman, J. Fohlman, and P. A. Peterson. 1980. Complete amino acid sequence of pooled papain-solubilized HLA-A, -B, and -C antigens: relatedness to immunoglobulins and internal homologies. Proc.Natl.Acad.Sci.U.S.A 77:1129-1133.

8. Springer, T. A. and J. L. Strominger. 1976. Detergent-soluble HLA antigens contain a hydrophilic region at the $\mathrm{COOH}$-terminus and a penultimate hydrophobic region. Proc.Natl.Acad.Sci.U.S.A 73:2481-2485. 
9. Robinson, P. J., L. Lundin, K. Sege, L. Graf, H. Wigzell, and P. A. Peterson. 1981. Location of the mouse $\beta_{2}$-microglobulin gene $B 2 m$ determined by linkage analysis. Immunogenetics 14:449-452.

10. Coligan, J. E., T. J. Kindt, H. Uehara, J. Martinko, and S. G. Nathenson. 1981. Primary structure of a murine transplantation antigen. Nature 291:35-39.

11. Cresswell, P., T. Springer, J. L. Strominger, M. J. Turner, H. M. Grey, and R. T. Kubo. 1974. Immunological identity of the small subunit of HLA antigens and $\beta_{2}$-microglobulin and its turnover on the cell membrane. Proc.Natl.Acad.Sci.U.S.A $71: 2123-2127$.

12. Grey, H. M., R. T. Kubo, S. M. Colon, M. D. Poulik, P. Cresswell, T. Springer, M. Turner, and J. L. Strominger. 1973. The small subunit of HLA antigens is $\beta_{2}$-microglobulin. J.Exp.Med. 138:1608-1612.

13. Pamer, E. and P. Cresswell. 1998. Mechanisms of MHC class I--restricted antigen processing. Annu.Rev.Immunol. 16:323-358.

14. Reits, E. A., J. C. Vos, M. Gromme, and J. Neefjes. 2000. The major substrates for TAP in vivo are derived from newly synthesized proteins. Nature 404:774-778.

15. Schubert, U., L. C. Anton, J. Gibbs, C. C. Norbury, J. W. Yewdell, and J. R. Bennink. 2000. Rapid degradation of a large fraction of newly synthesized proteins by proteasomes. Nature 404:770-774. 
16. Rock, K. L., C. Gramm, L. Rothstein, K. Clark, R. Stein, L. Dick, D. Hwang, and A. L. Goldberg. 1994. Inhibitors of the proteasome block the degradation of most cell proteins and the generation of peptides presented on MHC class I molecules. Cell 78:761-771.

17. Rock, K. L. and A. L. Goldberg. 1999. Degradation of cell proteins and the generation of MHC class I-presented peptides. Annu.Rev.Immunol. 17:739-779.

18. Cascio, P., C. Hilton, A. F. Kisselev, K. L. Rock, and A. L. Goldberg. 2001. 26S proteasomes and immunoproteasomes produce mainly N-extended versions of an antigenic peptide. EMBO J. 20:2357-2366.

19. de la, S. H., D. Hanau, D. Fricker, A. Urlacher, A. Kelly, J. Salamero, S. H. Powis, L. Donato, H. Bausinger, and M. Laforet. 1994. Homozygous human TAP peptide transporter mutation in HLA class I deficiency. Science 265:237-241.

20. Townsend, A., C. Ohlen, J. Bastin, H. G. Ljunggren, L. Foster, and K. Karre. 1989. Association of class I major histocompatibility heavy and light chains induced by viral peptides. Nature 340:443-448.

21. Van Kaer, L., P. G. Ashton-Rickardt, H. L. Ploegh, and S. Tonegawa. 1992. TAP1 mutant mice are deficient in antigen presentation, surface class I molecules, and $\mathrm{CD}^{-} 8^{+}$T cells. Cell 71:1205-1214.

22. Bodmer, H. C., J. M. Bastin, B. A. Askonas, and A. R. Townsend. 1989. Influenzaspecific cytotoxic T-cell recognition is inhibited by peptides unrelated in both sequence and MHC restriction. Immunology 66:163-169. 
23. Schumacher, T. N., M. T. Heemels, J. J. Neefjes, W. M. Kast, C. J. Melief, and H. L. Ploegh. 1990. Direct binding of peptide to empty MHC class I molecules on intact cells and in vitro. Cell 62:563-567.

24. Cresswell, P. 2000. Intracellular surveillance: controlling the assembly of MHC class I-peptide complexes. Traffic. 1:301-305.

25. Grandea, A. G., III and L. Van Kaer. 2001. Tapasin: an ER chaperone that controls MHC class I assembly with peptide. Trends Immunol. 22:194-199.

26. Ortmann, B., M. J. Androlewicz, and P. Cresswell. 1994. MHC class I/ $\beta_{2^{-}}$ microglobulin complexes associate with TAP transporters before peptide binding. Nature 368:864-867.

27. Suh, W. K., M. F. Cohen-Doyle, K. Fruh, K. Wang, P. A. Peterson, and D. B. Williams. 1994. Interaction of MHC class I molecules with the transporter associated with antigen processing. Science 264:1322-1326.

28. Garbi, N., P. Tan, A. D. Diehl, B. J. Chambers, H. G. Ljunggren, F. Momburg, and G. J. Hammerling. 2000. Impaired immune responses and altered peptide repertoire in tapasin-deficient mice. Nat.Immunol. 1:234-238.

29. Grandea, A. G., III, T. N. Golovina, S. E. Hamilton, V. Sriram, T. Spies, R. R. Brutkiewicz, J. T. Harty, L. C. Eisenlohr, and L. Van Kaer. 2000. Impaired assembly yet normal trafficking of MHC class I molecules in Tapasin mutant mice. Immunity. 13:213-222. 
30. Lehner, P. J., M. J. Surman, and P. Cresswell. 1998. Soluble tapasin restores MHC class I expression and function in the tapasin-negative cell line 220. Immunity. $8: 221-231$.

31. Dick, T. P., N. Bangia, D. R. Peaper, and P. Cresswell. 2002. Disulfide bond isomerization and the assembly of MHC class I-peptide complexes. Immunity. $16: 87-98$

32. Suh, W. K., E. K. Mitchell, Y. Yang, P. A. Peterson, G. L. Waneck, and D. B. Williams. 1996. MHC class I molecules form ternary complexes with calnexin and TAP and undergo peptide-regulated interaction with TAP via their extracellular domains. J.Exp.Med. 184:337-348.

33. Samelson, L. E., R. N. Germain, and R. H. Schwartz. 1983. Monoclonal antibodies against the antigen receptor on a cloned T-cell hybrid. Proc.Natl.Acad.Sci.U.S.A 80:6972-6976.

34. Kronenberg, M., G. Siu, L. E. Hood, and N. Shastri. 1986. The molecular genetics of the T-cell antigen receptor and T-cell antigen recognition. Annu.Rev.Immunol. 4:529-591.

35. Tonegawa, S. 1983. Somatic generation of antibody diversity. Nature 302:575-581.

36. Garboczi, D. N., P. Ghosh, U. Utz, Q. R. Fan, W. E. Biddison, and D. C. Wiley. 1996. Structure of the complex between human T-cell receptor, viral peptide and HLA-A2. Nature 384:134-141. 
37. Garcia, K. C., M. Degano, R. L. Stanfield, A. Brunmark, M. R. Jackson, P. A. Peterson, L. Teyton, and I. A. Wilson. 1996. An $\alpha \beta$ T cell receptor structure at 2.5 A and its orientation in the TCR-MHC complex. Science 274:209-219.

38. Housset, D., G. Mazza, C. Gregoire, C. Piras, B. Malissen, and J. C. FontecillaCamps. 1997. The three-dimensional structure of a T-cell antigen receptor $V_{\alpha} V_{\beta}$ heterodimer reveals a novel arrangement of the $\mathrm{V}_{\beta}$ domain. EMBO J. 16:42054216.

39. Reiser, J. B., C. Darnault, A. Guimezanes, C. Gregoire, T. Mosser, A. M. SchmittVerhulst, J. C. Fontecilla-Camps, B. Malissen, D. Housset, and G. Mazza. 2000. Crystal structure of a $\mathrm{T}$ cell receptor bound to an allogeneic MHC molecule. Nat.Immunol. 1:291-297.

40. Patten, P., T. Yokota, J. Rothbard, Y. Chien, K. Arai, and M. M. Davis. 1984. Structure, expression and divergence of T-cell receptor $\beta$-chain variable regions. Nature 312:40-46.

41. Sun, R., S. E. Shepherd, S. S. Geier, C. T. Thomson, J. M. Sheil, and S. G. Nathenson. 1995. Evidence that the antigen receptors of cytotoxic T lymphocytes interact with a common recognition pattern on the $\mathrm{H}-2 \mathrm{~K}^{\mathrm{b}}$ molecule. Immunity. 3:573-582.

42. Sant'Angelo, D. B., G. Waterbury, P. Preston-Hurlburt, S. T. Yoon, R. Medzhitov, S. C. Hong, and C. A. Janeway, Jr. 1996. The specificity and orientation of a TCR to its peptide-MHC class II ligands. Immunity. 4:367-376. 
43. Groth, C. G. 1972. Landmarks in clinical renal transplantation. Surg. Gynecol.Obstet. $134: 327-328$.

44. Kahan, B. D. 1989. Cyclosporine. N.Engl.J.Med. 321:1725-1738.

45. Abraham, R. T. and G. J. Wiederrecht. 1996. Immunopharmacology of rapamycin. Annu.Rev.Immunol. 14:483-510.

46. Suthanthiran, M., R. E. Morris, and T. B. Strom. 1996. Immunosuppressants: cellular and molecular mechanisms of action. Am.J.Kidney Dis. 28:159-172.

47. Brinkmann, V., D. D. Pinschewer, L. Feng, and S. Chen. 2001. FTY720: altered lymphocyte traffic results in allograft protection. Transplantation 72:764-769.

48. Yanagawa, Y., K. Sugahara, H. Kataoka, T. Kawaguchi, Y. Masubuchi, and K. Chiba. 1998. FTY720, a novel immunosuppressant, induces sequestration of circulating mature lymphocytes by acceleration of lymphocyte homing in rats. II. FTY720 prolongs skin allograft survival by decreasing $\mathrm{T}$ cell infiltration into grafts but not cytokine production in vivo. J.Immunol. 160:5493-5499.

49. Hariharan, S., C. P. Johnson, B. A. Bresnahan, S. E. Taranto, M. J. McIntosh, and D. Stablein. 2000. Improved graft survival after renal transplantation in the United States, 1988 to 1996. N.Engl.J.Med. 342:605-612.

50. Adu, D., P. Cockwell, N. J. Ives, J. Shaw, and K. Wheatley. 2003. Interleukin-2 receptor monoclonal antibodies in renal transplantation: meta-analysis of randomised trials. $B M J 326: 789$. 
51. Lietz, K., R. John, A. Beniaminovitz, E. M. Burke, N. Suciu-Foca, D. M. Mancini, N. M. Edwards, and S. Itescu. 2003. Interleukin-2 receptor blockade in cardiac transplantation: influence of HLA-DR locus incompatibility on treatment efficacy. Transplantation 75:781-787.

52. U.S. Depatment of Health and Human Resources. 2003 Annual Report: The U.S. Organ Procurement and Transplantation Network and The Scientific Registry of Transplant Recipients. 2003.

53. 1983. Liver grafting. Transplantation 35:109-111.

54. Gordon, R. D., J. J. Fung, B. Markus, I. Fox, S. Iwatsuki, C. O. Esquivel, A. Tzakis, S. Todo, and T. E. Starzl. 1986. The antibody crossmatch in liver transplantation. Surgery 100:705-715.

55. Ryan, E. A., J. R. Lakey, R. V. Rajotte, G. S. Korbutt, T. Kin, S. Imes, A. Rabinovitch, J. F. Elliott, D. Bigam, N. M. Kneteman, G. L. Warnock, I. Larsen, and A. M. Shapiro. 2001. Clinical outcomes and insulin secretion after islet transplantation with the Edmonton protocol. Diabetes 50:710-719.

56. Dausset, J. 1981. The major histocompatibility complex in man. Science 213:14691474.

57. Snell, G. D. 1981. Studies in histocompatibility. Science 213:172-178.

58. Lechler, R. I. and J. R. Batchelor. 1982. Restoration of immunogenicity to passenger cell-depleted kidney allografts by the addition of donor strain dendritic cells. J.Exp.Med. 155:31-41. 
59. Auchincloss, H., Jr., R. Lee, S. Shea, J. S. Markowitz, M. J. Grusby, and L. H. Glimcher. 1993. The role of "indirect" recognition in initiating rejection of skin grafts from major histocompatibility complex class II-deficient mice. Proc.Natl.Acad.Sci.U.S.A 90:3373-3377.

60. Benichou, G., P. A. Takizawa, C. A. Olson, M. McMillan, and E. E. Sercarz. 1992. Donor major histocompatibility complex (MHC) peptides are presented by recipient MHC molecules during graft rejection. J.Exp.Med. 175:305-308.

61. Fangmann, J., R. Dalchau, G. J. Sawyer, C. A. Priestley, and J. W. Fabre. 1992. T cell recognition of donor major histocompatibility complex class I peptides during allograft rejection. Eur.J.Immunol. 22:1525-1530.

62. Liu, Z., N. S. Braunstein, and N. Suciu-Foca. 1992. T cell recognition of allopeptides in context of syngeneic MHC. J.Immunol. 148:35-40.

63. Shoskes, D. A. and K. J. Wood. 1994. Indirect presentation of MHC antigens in transplantation. Immunol.Today 15:32-38.

64. Valujskikh, A., D. Matesic, A. Gilliam, D. Anthony, T. M. Haqqi, and P. S. Heeger. 1998. T cells reactive to a single immunodominant self-restricted allopeptide induce skin graft rejection in mice. J.Clin.Invest 101:1398-1407.

65. Benichou, G., A. Valujskikh, and P. S. Heeger. 1999. Contributions of direct and indirect $\mathrm{T}$ cell alloreactivity during allograft rejection in mice. J.Immunol. 162:352358. 
66. Liu, Z., Y. K. Sun, Y. P. Xi, B. Hong, P. E. Harris, E. F. Reed, and N. Suciu-Foca. 1993. Limited usage of $T$ cell receptor $V_{\beta}$ genes by allopeptide-specific $T$ cells. J.Immunol. 150:3180-3186.

67. Ciubotariu, R., Z. Liu, A. I. Colovai, E. Ho, S. Itescu, S. Ravalli, M. A. Hardy, R. Cortesini, E. A. Rose, and N. Suciu-Foca. 1998. Persistent allopeptide reactivity and epitope spreading in chronic rejection of organ allografts. J.Clin.Invest 101:398-405.

68. Vella, J. P., M. Spadafora-Ferreira, B. Murphy, S. I. Alexander, W. Harmon, C. B. Carpenter, and M. H. Sayegh. 1997. Indirect allorecognition of major histocompatibility complex allopeptides in human renal transplant recipients with chronic graft dysfunction. Transplantation 64:795-800.

69. Sheil, J. M., T. D. Schell, S. E. Shepherd, G. F. Klimo, J. M. Kioschos, and Y. Paterson. 1994. Presentation of a horse cytochrome $c$ peptide by multiple H-2 ${ }^{\mathrm{b}}$ class I major histocompatibility complex (MHC) molecules to $\mathrm{C} 57 \mathrm{BL} / 6-$ and bm1derived cytotoxic T lymphocytes: presence of a single MHC anchor residue may confer efficient peptide-specific CTL recognition. Eur.J Immunol. 24:2141-2149.

70. Melvold, R. W., H. I. Kohn, and G. R. Dunn. 1982. History and genealogy of the $\mathrm{H}-2 \mathrm{~K}^{\mathrm{b}}$ mutants from the C57BL/6Kh colony. Immunogenetics 15:177-185.

71. Lewis, J., M. Foo, S. S. Geier, P. A. Kumar, S. G. Nathenson, and J. A. Bluestone. 1988. Cytotoxic T lymphocyte recognition of novel allodeterminants expressed on in vitro selected $\mathrm{H}-2 \mathrm{~K}^{\mathrm{b}}$ mutants. J Immunol. 141:728-735. 
72. Gregory, S. G., M. Sekhon, J. Schein, S. Zhao, K. Osoegawa, C. E. Scott, R. S. Evans, P. W. Burridge, T. V. Cox, C. A. Fox, R. D. Hutton, I. R. Mullenger, K. J. Phillips, J. Smith, J. Stalker, G. J. Threadgold, E. Birney, K. Wylie, A. Chinwalla, J. Wallis, L. Hillier, J. Carter, T. Gaige, S. Jaeger, C. Kremitzki, D. Layman, J. Maas, R. McGrane, K. Mead, R. Walker, S. Jones, M. Smith, J. Asano, I. Bosdet, S. Chan, S. Chittaranjan, R. Chiu, C. Fjell, D. Fuhrmann, N. Girn, C. Gray, R. Guin, L. Hsiao, M. Krzywinski, R. Kutsche, S. S. Lee, C. Mathewson, C. McLeavy, S. Messervier, S. Ness, P. Pandoh, A. L. Prabhu, P. Saeedi, D. Smailus, L. Spence, J. Stott, S. Taylor, W. Terpstra, M. Tsai, J. Vardy, N. Wye, G. Yang, S. Shatsman, B. Ayodeji, K. Geer, G. Tsegaye, A. Shvartsbeyn, E. Gebregeorgis, M. Krol, D. Russell, L. Overton, J. A. Malek, M. Holmes, M. Heaney, J. Shetty, T. Feldblyum, W. C. Nierman, J. J. Catanese, T. Hubbard, R. H. Waterston, J. Rogers, P. J. de Jong, C. M. Fraser, M. Marra, J. D. McPherson, and D. R. Bentley. 2002. A physical map of the mouse genome. Nature 418:743-750.

73. Gruen, J. R. and S. M. Weissman. 1997. Evolving views of the major histocompatibility complex. Blood 90:4252-4265.

74. Gunther, E. and L. Walter. 2000. Comparative genomic aspects of rat, mouse and human MHC class I gene regions. Cytogenet.Cell Genet. 91:107-112.

75. Newell, W. R., J. Trowsdale, and S. Beck. 1996. MHCDB: database of the human MHC (release 2). Immunogenetics 45:6-8. 


\title{
CHAPTER 2
}

\begin{abstract}
A Cloned CD8 ${ }^{+}$Cytotoxic T Cell Displays both $\mathrm{H}-2 \mathrm{~K}^{\mathrm{b}}$ - and $\mathrm{H}-2 \mathrm{D}^{\mathrm{b}}-$ Restricted Recognition of the Horse Cytochrome $c$ Peptide, p41-49
\end{abstract}

Marc A. Frankenberry ${ }^{1}$, Todd D. Schell ${ }^{2}$ and James M. Sheil ${ }^{1}$

Departments of Microbiology, Immunology \& Cell Biology, West Virginia University School of Medicine, Morgantown, WV $26506^{1}$ and Microbiology and Immunology, The Pennsylvania State University College of Medicine, Hershey, PA $17033^{2}$ 


\begin{abstract}
Antigen recognition by $\mathrm{CD}^{+} \mathrm{CTLs}$ occurs in response to a small peptide tightly bound to a single "self" class I MHC molecule. We reported previously, however, that $\mathrm{CD}^{+}$CTLs from $\mathrm{C} 57 \mathrm{BL} / 6$ mice are restricted to both $\mathrm{H}-2 \mathrm{~K}^{\mathrm{b}}$ and $\mathrm{H}-2 \mathrm{D}^{\mathrm{b}}$ class I molecules in their response to the horse cyt $c$-derived peptide, p41-49. In this study, we examine the structural features of $\mathrm{H}-2 \mathrm{~K}^{\mathrm{b}} / \mathrm{cyt} c \mathrm{p} 41-49$ and $\mathrm{H}-2 \mathrm{D}^{\mathrm{b}} / \mathrm{cyt} c \mathrm{p} 41-49$ complexes responsible for this dual recognition. A representative cloned CTL, designated Clone B6.H-4.1c, is induced by similar concentrations of peptide added to either $\mathrm{H}-2 \mathrm{~K}^{\mathrm{b}}$ - or $\mathrm{H}-2 \mathrm{D}^{\mathrm{b}}$-expressing targets, demonstrating comparable recognition of both $\mathrm{MHC} /$ peptide complexes. To determine the stability of $\mathrm{H}-2 \mathrm{~K}^{\mathrm{b}} / \mathrm{cyt} c \mathrm{p} 41-49$ and $\mathrm{H}-2 \mathrm{D}^{\mathrm{b}} / \mathrm{cyt} c \mathrm{p} 41-49$ complexes, we conducted peptide competition and RMA-S stabilization experiments. Displacement of horse cyt $c$ p41-49 with a competitor peptide MI B chain p7-15, also shown to bind to $\mathrm{H}-2 \mathrm{~K}^{\mathrm{b}}$ and $\mathrm{H}-2 \mathrm{D}^{\mathrm{b}}$, significantly increases the optimal concentration of the horse cyt $c$ p 41-49 required for lysis of either $H-2 K^{b}-$ or $H-2 D^{b}$-expressing targets by Clone B6.H-4.1c. The dissociation rates for both $\mathrm{H}-2 \mathrm{~K} / \mathrm{cyt} c \mathrm{p} 41-49$ and $\mathrm{H}-2 \mathrm{D}^{\mathrm{b}} / \mathrm{cyt} c$ p41-49 complexes are also comparable, reaching a steady state at 60 minutes in both cases. Computer-generated models of both complexes indicate that the bound peptide configurations display a prominent upward bulge with similar surface accessibility, due to the presence of Pro ${ }^{44}-\mathrm{Gly}^{45}$. Thus, the $\mathrm{Pro}^{44}-\mathrm{Gly}^{45}$ dipeptide sequence may be critical in the dual restricted response of $\mathrm{CD}^{+} \mathrm{CTLs}$ to this peptide.
\end{abstract}




\section{INTRODUCTION}

One of the basic tenets of immunology that governs our understanding of antigen recognition by $\mathrm{CD}^{+}$cytotoxic $\mathrm{T}$ lymphocytes (CTL) is "self MHC restriction". A self major histocompatibility complex (MHC)-restricted $\mathrm{CD} 8^{+} \mathrm{CTL}$ responds to a short peptide of $8-10$ amino acid residues, presented in the context of a single self class I MHC molecule (1-5). In recent years, however, several studies in both human and murine systems (6-14) have demonstrated that a single peptide can be presented efficiently to CTLs by multiple class I MHC molecules. Johnson and coworkers (8) showed that the nonamer peptide, p584-592, from the human immunodeficiency virus-1 (HIV-1) envelope glycoprotein (gp41), binds to and stabilizes two human class I MHC molecules, HLA-B14 and HLA-B8. Both complexes are efficiently recognized by distinct CTL clones derived from different HIV-1 seropositive individuals (8). Also, Ploegh and coworkers (6) showed that the Sendai virus nucleoprotein-derived peptide (SEV), SEV-9, binds to $\mathrm{H}-2 \mathrm{~K}^{\mathrm{b}}$ and $\mathrm{H}-2 \mathrm{D}^{\mathrm{b}}$ murine class I MHC molecules and is recognized efficiently by both $\mathrm{H}-2 \mathrm{~K}^{\mathrm{b}}$ - and $\mathrm{H}-2 \mathrm{D}^{\mathrm{b}}$-restricted CTLs. Similarly, we have observed that the mouse insulin I B chain p7-15 peptide (MI B chain p7-15) can bind to both $\mathrm{H}-2 \mathrm{~K}^{\mathrm{b}}$ and $\mathrm{H}-2 \mathrm{D}^{\mathrm{b}}$ and can elicit either $\mathrm{H}-2 \mathrm{~K}^{\mathrm{b}}$ - or $\mathrm{H}-2 \mathrm{D}^{\mathrm{b}}$-restricted CTLs, respectively (12).

To better understand the basis for CTL induction by peptide antigens derived from relatively simple proteins, we established a model system in our laboratory to examine the induction of CTLs specific for cytochrome $c$ (cyt $c$ )-derived peptide antigens. We previously reported that a CTL response, induced by in vitro priming with a tryptic digest of denatured horse cyt $c(15)$, is specific for the horse cytochrome $c$ - 
derived nonamer peptide $\mathrm{p} 41-49$ and is restricted to both $\mathrm{H}-2 \mathrm{~K}^{\mathrm{b}}$ and $\mathrm{H}-2 \mathrm{D}^{\mathrm{b}}$. Clone B6.H-4.1 $\mathrm{c}$ is representative of the CTL population and its response is dual-restricted to both $\mathrm{H}-2 \mathrm{~K}^{\mathrm{b}}$ and $\mathrm{H}-2 \mathrm{D}^{\mathrm{b}}$.

We considered that the appearance of such dual class $\mathrm{I} H-2^{\mathrm{b}}$-restricted CTLs might result from the in vitro priming approach used in their induction. To address this possibility, we induced horse cyt $c$-specific CTLs by in vivo priming with either the horse cyt $c$ tryptic digest or the cyt $c$ p41-49 peptide alone. In both instances we obtained CTLs with the identical peptide specificity and dual restriction characteristics as originally reported for the in vitro-derived CTLs (unpublished observations). Similarly, Pease and coworkers (16) found that an $H-2 L^{d}$-allospecific CTL, Clone $2 \mathrm{C}$, recognizes the self peptide, $\mathrm{dEV}-8$, presented by both the self class I molecule $\mathrm{H}-2 \mathrm{~K}^{\mathrm{b}}$ and its closely related mutant, $\mathrm{H}-2 \mathrm{~K}^{\mathrm{bm} 3}$ (16-19). Furthermore, this cloned CTL line also responds to a peptide derived from 2-oxoglutarate dehydrogenase, designated $\mathrm{p} 2 \mathrm{Ca}$, in the context of both $\mathrm{H}-2 \mathrm{~K}^{\mathrm{b}}$ and $\mathrm{H}-2 \mathrm{~L}^{\mathrm{d}}(16)$.

To determine how a $\mathrm{T}$ cell receptor (TCR) interacts with the distal surface of the MHC/peptide complex, we (in collaboration with Nathenson and coworkers) analyzed a large number of alloreactive CTLs for their reactivity on a diverse panel of $\mathrm{H}-2 \mathrm{~K}^{\mathrm{b}}$ mutant cell lines (20). The results of this study revealed that the TCR is aligned over the distal surface of the peptide $/ \mathrm{K}^{\mathrm{b}}$ complex, parallel to the $\beta$-pleated sheets of the $\alpha 1$ and $\alpha 2$ domains. Janeway and coworkers (21) also reported that the TCR specific for a class II MHC/peptide complex is oriented in a similar manner, with its variable $\alpha\left(\mathrm{V}_{\alpha}\right)$ domain aligned over the amino terminus of the bound peptide and the TCR $V_{\beta}$ domain aligned over its carboxyl terminus. 
Further insight into the structural relationships that underlie the interactions among the MHC class I molecule, the bound peptide and the TCR in this trimolecular complex has been revealed by resolution of the three-dimensional x-ray crystallographic structures for the trimolecular complex (22-26). These x-ray crystal structures confirmed that the TCR $V_{\alpha}$ domain is aligned with the peptide amino terminus and the TCR $V_{\beta}$ domain with the peptide carboxyl terminus (23-25).

Three distinct TCR complementarity-determining regions (CDR), designated CDR1, CDR2, and CDR3, are formed by the interaction of the TCR $V_{\alpha}$ and $V_{\beta}$ domains. These TCR hypervariable regions make direct contact with MHC and peptide residues at the distal surface of the MHC/peptide complex. Bjorkman and coworkers $(22,26)$ showed that the relatively invariant CDR1 and CDR2 regions contact the conserved residues on the class I MHC $\alpha$ helices, and the highly diverse sequences of the CDR3 region interact directly with the bound peptide. This interaction of the CDR3 region with bound peptide was verified both by direct TCR mutagenesis studies (27-30) and by direct binding of MHC/peptide tetramers to TCRs expressed on transfected cell lines (31).

In this study we employ RMA-S stabilization assays $(32,33)$ and peptide competition experiments $(34,35)$ to show that the horse cyt $c$ p41-49 peptide binds efficiently to both $\mathrm{H}-2 \mathrm{~K}^{\mathrm{b}}$ and $\mathrm{H}-2 \mathrm{D}^{\mathrm{b}}$ class I MHC molecules. We also demonstrate that both $\mathrm{H}-2 \mathrm{~K}^{\mathrm{b}}$ and $\mathrm{H}-2 \mathrm{D}^{\mathrm{b}}$-restricted responses of CTL Clone B6.H-4.1c to cyt $c$ p41-49 require similar peptide concentrations. This indicates that the peptide-specific response in the context of $\mathrm{H}-2 \mathrm{~K}^{\mathrm{b}}$ is equivalent to the $\mathrm{H}-2 \mathrm{D}^{\mathrm{b}}$-restricted response.

To understand the structural basis for this anomalous CTL response, we utilized the coordinates obtained from previously published x-ray crystallography studies for 
$\mathrm{H}-2 \mathrm{~K}^{\mathrm{b}}(36,37)$ and $\mathrm{H}-2 \mathrm{D}^{\mathrm{b}}(38)$ to generate $\mathrm{H}-2 \mathrm{~K}^{\mathrm{b}} / \mathrm{cyt} c \mathrm{p} 41-49$ and $\mathrm{H}-2 \mathrm{D}^{\mathrm{b}} / \mathrm{cyt} c \mathrm{p} 41-49$ complexes. These computer-generated molecular models were used to address the following questions: (i) How does the horse cyt $c$-derived peptide p41-49 bind efficiently to both $\mathrm{H}-2 \mathrm{~K}^{\mathrm{b}}$ and $\mathrm{H}-2 \mathrm{D}^{\mathrm{b}}$ class I MHC molecules? and (ii) How does Clone B6.H-4.1c respond efficiently to the two complexes, $\mathrm{H}-2 \mathrm{~K}^{\mathrm{b}} / \mathrm{cyt} c \mathrm{p} 41-49$ and $\mathrm{H}-2 \mathrm{D}^{\mathrm{b}} / \mathrm{cyt} c \mathrm{p} 41-49$ ? 


\section{MATERIALS AND METHODS}

\section{Animals}

Female C57BL/6 (B6) mice used in this study were obtained from this laboratory's breeding colony at West Virginia University Health Sciences Center Vivarium. The B6 colony was established in 1987 and has been maintained since then at the West Virginia University Health Sciences Center Vivarium. All mice used in this study were between 8 and 12 weeks of age.

\section{Target cell lines}

Transfected cell lines were derived from the thymidine kinase-negative L cell $\left(\mathrm{H}-2^{\mathrm{k}}\right)$ fibroblast line designated $\mathrm{LMTK}^{-}$and grown as adherent cultures in RPMI-1640 media supplemented with 10\% FCS, $100 \mathrm{mM}$ HEPES, $100 \mathrm{U} / \mathrm{ml}$ penicillin, $100 \mu \mathrm{g} / \mathrm{ml}$ streptomycin and $2 \mathrm{mM}$ L-glutamine (RP-10), as previously described (15). All transfected cell lines, which include $\mathrm{L}+\mathrm{K}^{\mathrm{b}}$ and $\mathrm{L}+\mathrm{D}^{\mathrm{b}}$ (as well as the $\mathrm{LMTK}^{-}$cell line), were kindly provided by Drs. S. G. Nathenson and R. Zeff. Appropriate H-2 ${ }^{b}$ class I cell surface expression was verified by flow cytometry in our laboratory (data not shown).

\section{Synthesis of peptides}

Drs. J. W. Yewdell and J. R. Bennink, generously provided the peptides, horse cyt $c$ p41-49 [G-Q-A-P-G-F-T-Y-T] and MI B chain p7-15 [C-G-P-H-L-V-E-A-L]. Peptides were synthesized by fMoc chemistry using an automated peptide synthesizer (9050 MilliGen PepSynthesizer), as previously described (39). Amino acid composition and purity was determined by HPLC tracing (Waters 600E) and the Pico Tag Amino Acid 
Analysis System (Waters). Lyophilized peptides were solubilized in sterile 1X PBS at appropriate stock concentrations. For the purpose of peptide competition assays, we have utilized horse cyt $c$ p41-49 as the target peptide, and MI B chain p7-15 as the competitor peptide.

\section{RMA-S stabilization assays}

Peptide-induced stabilization of RMA-S cells has been described previously $(32,33)$. Briefly, the B6-derived, transporter associated with antigen processing (TAP)-deficient, murine cell line RMA-S $(40,41)$ was grown initially in RP-10 media in a humidified incubator at $37^{\circ} \mathrm{C}$ with $7 \% \mathrm{CO}_{2}$. RMA-S cells $\left(2.5 \times 10^{6}\right)$ were transferred to $30^{\circ} \mathrm{C}$ in $7 \%$ $\mathrm{CO}_{2}$ for $18-20 \mathrm{~h}$ to induce stable cell surface expression $\mathrm{H}-2 \mathrm{~K}^{\mathrm{b}}$ and $\mathrm{H}-2 \mathrm{D}^{\mathrm{b}}$ class $\mathrm{I}$ molecules. Cells were then washed twice with $1 \mathrm{X}$ PBS, containing $2 \%$ FCS and $0.01 \%$ sodium azide (PBS-2\%), and incubated with $10 \mu \mathrm{M}$ peptide (horse cyt $c$ p41-49 or MI B chain p7-15) for one hour. Peptide-pulsed RMA-S cells were washed twice with PBS$2 \%$ to remove excess peptide, resuspended in RP-10 media, and incubated in a humidified incubator at $37^{\circ} \mathrm{C}, 7 \% \mathrm{CO}_{2}$. RMA-S cells $\left(5 \times 10^{5}\right)$ were incubated with PEconjugated anti-H-2 $\mathrm{K}^{\mathrm{b}}$ or anti-H-2 $\mathrm{D}^{\mathrm{b}}$ monoclonal antibodies (mAbs) and analyzed by flow cytometry at $0,30,60,120$ and $180 \mathrm{~min}$.

\section{Antibodies and flow cytometry}

Phycoerythin (PE)-conjugated anti-H-2K $\mathrm{K}^{\mathrm{b}}$ (42) and anti-H-2 $\mathrm{D}^{\mathrm{b}}$ (43) mAbs were purchased from Caltag Laboratories ${ }^{\circledR}$ (Burlingame, CA). Peptide-pulsed RMA-S cells (5 $\left.\mathrm{X} 10^{5}\right)$ were incubated for $45 \mathrm{~min}$ on ice with $20 \mu \mathrm{l}$ of $\mathrm{mAb}(1: 20)$ and washed twice with 
PBS-2\%. RMA-S cells $\left(\begin{array}{lll}1 & \mathrm{X} & 10^{5}\end{array}\right)$ were analyzed for fluorescence intensity using a FACScan ${ }^{\circledR}$ flow cytometer (Becton Dickinson, Mountain View, CA). The mean channel fluorescence (MCF) indicates the mean channel number of fluorescence, detected from 10,000 gated cells. The fluorescence index was calculated, as previously determined (35), using the following formula:

(MCF in the presence of peptide) - (MCF in the absence of peptide)

(MCF in the absence of peptide)

\section{CTL Clone B6.H-4.1c}

The CTL Clone B6.H-4.1c was maintained in long-term culture as previously described (15). Briefly, $4 \times 10^{5}$ Clone B6.H-4.1c cells were incubated in a 24-well flat-bottom plate with $5 \times 10^{6}$ irradiated (2000 rads) B6 spleen cells plus $2 \mu \mathrm{M}$ horse cyt $c$ p41-49 suspended in RP-10 media. Clone B6.H-4.1c CTLs were analyzed for lytic reactivity on day five and subsequently restimulated on day 7 of culture.

\section{${ }^{51}$ Cr-release assay}

The lytic activity of Clone B6.H-4.1c was determined by a standard in vitro $4-\mathrm{h}{ }^{51} \mathrm{Cr}$ release assay (44). Briefly, 1 X $10^{6}$ target cells were incubated in $50 \mu 1 \mathrm{RP}-10$ media plus $100 \mu \mathrm{Ci}$ sodium chromate $51\left({ }^{51} \mathrm{Cr}\right.$; New England Nuclear, Boston, MA) per 1 X $10^{6}$ cells for 60 min at $37^{\circ} \mathrm{C} 7 \% \mathrm{CO}_{2}$. After ${ }^{51} \mathrm{Cr}$ labeling, target cells were washed with $1 \mathrm{X}$ HBSS and resuspended in $10 \mathrm{ml} \mathrm{RP}-10$. Following an additional 30 min incubation in a $37^{\circ} \mathrm{C}$ water bath, target cells were washed in $1 \mathrm{X}$ HBSS and resuspended in RP-10 media at a final concentration of $2 \times 10^{5}$ cells $/ \mathrm{ml}$. Target cells were added (50 $\mu 1 /$ well) to 96 - 
well round-bottom microtiter plates. Exogenous peptides to be tested were added in a volume of $50 \mu \mathrm{l} /$ well at a final concentration of $2 \mu \mathrm{M}$ and incubated for $20 \mathrm{~min}$ at $37^{\circ} \mathrm{C}$, $7 \% \mathrm{CO}_{2}$. Clone B6.H-4.1c effector cells were added in a volume of $100 \mu \mathrm{l} /$ well with the following effector-to-target ratios: 30:1, 10:1, 3:1 and 1:1. Assay plates were incubated 4 h at $37^{\circ} \mathrm{C}, 7 \% \mathrm{CO}_{2}$ then centrifuged for $7 \mathrm{~min}$ at $1200 \mathrm{rpm}$. Supernatants $(100 \mu \mathrm{l})$ were collected from each well and transferred to 6 X $50 \mathrm{~mm}$ tubes for determination of total ${ }^{51} \mathrm{Cr}$ counts on an LKB Clinigamma Model 1272 counter (LKB Instruments, Finland). The "percent specific lysis" was determined as follows:

$$
\% \text { Specific Lysis }=\frac{\text { experimental cpm - spontaneous cpm }}{\text { maximum - spontaneous cpm }} \times 100
$$

In all experiments, the spontaneous release values of targets in the absence of CTL effectors was routinely $<10 \%$ of maximum lysis, as determined by addition of Triton X100 detergent to target cells.

\section{Minimum peptide concentration determination}

Final volume peptide concentrations ranging from $2 \mathrm{pM}$ to $2 \mu \mathrm{M}$ of horse cyt $c$ p41-49 were added to ${ }^{51} \mathrm{Cr}$-labeled target cells and incubated for $20 \mathrm{~min}$ at $37^{\circ} \mathrm{C}, 7 \% \mathrm{CO}_{2}$. Clone B6.H-4.1c effector CTLs were added in $100 \mu \mathrm{l} /$ well at a constant effector-to-target (E:T) ratio of 3:1. Assay plates were incubated for $4-\mathrm{h}$ at $37^{\circ} \mathrm{C}, 7 \% \mathrm{CO}_{2}$ and centrifuged for 7 min at $1200 \mathrm{rpm} ; 100 \mu \mathrm{l}$ supernatant was collected from each well and added to $6 \mathrm{x} 50$ $\mathrm{mm}$ tubes for counting. Minimum peptide concentrations were determined as the peptide concentration required to yield $30 \%$ lysis at a $3: 1 \mathrm{E}: \mathrm{T}$ ratio. 


\section{Peptide competition inhibition assays}

Peptide competition inhibition assays were conducted as described previously $(34,35)$. Briefly, a constant $10 \mu \mathrm{M}$ concentration of competitor peptide (MI B chain p7-15) was added to the same wells containing target peptide (horse cyt $c$ p41-49), with concentrations ranging from $2 \mathrm{pM}$ to $2 \mu \mathrm{M}$. Both target and competitor peptides were added to ${ }^{51} \mathrm{Cr}$-labeled target cells and incubated for 20 min at $37^{\circ} \mathrm{C}, 7 \% \mathrm{CO}_{2}$. Clone B6.H-4.1c effector CTLs were added at a constant E:T ratio of 3:1. Assay plates were incubated for 4-h at $37^{\circ} \mathrm{C}, 7 \% \mathrm{CO}_{2}$ centrifuged for $7 \mathrm{~min}$ at $1200 \mathrm{rpm}$. A volume of 100 $\mu 1$ supernatant was collected from each well and added to $6 \times 50 \mathrm{~mm}$ tubes for counting. The percent inhibition was determined by a students' $t$-test analysis of the difference in target peptide concentration required to yield $30 \%$ lysis at an E:T ratio of $3: 1$ in the presence and absence of competitor peptide.

\section{Molecular modeling}

Computer modeling was used to examine the similarities and differences in the binding of horse cyt $c$ p41-49 to both class I molecules and to better understand how the Clone B6.H-4.1c TCR might interact with the surface of both complexes. Horse cyt $c$ p41-49 was introduced into the antigen-binding cleft of both $\mathrm{H}-2 \mathrm{~K}^{\mathrm{b}}$ and $\mathrm{H}-2 \mathrm{D}^{\mathrm{b}}$ molecular structures using a Silicon Graphics UNIX-based computer with QUANTA/CHARMm software designed by Molecular Simulations, Inc. The coordinates for x-ray crystal structures, H-2K $\mathrm{K}^{\mathrm{b}}$ complexed with the SEV-9 p324-332 peptide [F-A-P-G-N-Y-P-A-L] $(36,37)$ and $\mathrm{H}-2 \mathrm{D}^{\mathrm{b}}$ complexed with the influenza A p366-374 peptide 
[A-S-N-E-N-M-E-T-M] (38), were obtained from the Brookhaven Protein Data Bank (PDB) (1vab and 1hoc, respectively). QUANTA/CHARMm software was used to introduce the horse cyt $c$ p $41-49$ sequence into the $H-2 K^{b}$ and $H-2 D^{b}$ x-ray crystal structures by replacing single amino acid residues. Each amino acid replacement was followed by 50 cycles of regularization at the steepest descent (45) and 200 cycles of the adopted basis set Newton-Raphson (ABNR) method (46). The peptide sequence was regularized after each amino acid residue replacement to reduce unfavorable bonds and angles. To find the minimum energy configuration, the completed $\mathrm{MHC} /$ peptide complex was then subjected to 100 cycles of CHARMm energy minimization, using the ABNR method.

\section{Statistical analysis}

All statistics in this study were performed by a paired, one-tailed Student's $t$-test. Statistical significance, where indicated, is established at the value of $\mathrm{p}<0.05$. 


\section{RESULTS}

We previously reported that B6-derived, horse cyt $c$-specific CTL effectors (represented in this study by CTL Clone B6.H-4.1c) can be induced by in vitro priming with syngeneic spleen cells coated with a tryptic digest of horse cyt $c$ (15). These CTLs are dual-restricted in their recognition of horse cyt $c$ p41-49, in that they are activated by and respond to this peptide in the context of both $\mathrm{H}-2 \mathrm{~K}^{\mathrm{b}}$ and $\mathrm{H}-2 \mathrm{D}^{\mathrm{b}}$ class I molecules. In the present study we describe the structural characteristics that provide the basis for this unique reactivity. More specifically, we address the following questions: (i) How does horse cyt $c$ p41-49 [G-Q-A-P-G-F-T-Y-T] bind efficiently to the peptide-binding clefts of both $\mathrm{H}-2 \mathrm{~K}^{\mathrm{b}}$ and $\mathrm{H}-2 \mathrm{D}^{\mathrm{b}}$ class I molecules? and (ii) How does CTL Clone B6.H-4.1c respond efficiently to both $\mathrm{H}-2 \mathrm{~K}$ /cyt $c$ p 41-49 and $\mathrm{H}-2 \mathrm{D}^{\mathrm{b}} /$ cyt $c \mathrm{p} 41-49$ complexes?

Horse cyt c p41-49, as the target peptide for Clone B6.H-4.1c, contain a single dominant anchor residue for binding to $H-2 K^{b}$ and a strong anchor residue for binding to $H-2 D^{b}$

To identify the important peptide anchor residues for horse cyt $c$ p41-49 binding in the clefts of $H-2 K^{b}$ and $H-2 D^{b}$, we examined the peptide sequence for the appropriate consensus peptide-binding motifs as described previously by Rammensee and coworkers (47). In addition, we evaluated the MI B chain p7-15 peptide sequence [C-G-P-H-L-V-E-A-L], which also binds to both $H-2 K^{b}$ and $H-2 D^{b}$, (12) for the presence of anchor residues based on these peptide motifs for $\mathrm{H}-2 \mathrm{~K}^{\mathrm{b}}$ and $\mathrm{H}-2 \mathrm{D}^{\mathrm{b}}$ binding (47). We previously determined that MI B chain p7-15 is the target antigen for $\mathrm{H}-2 \mathrm{~K}^{\mathrm{b}}$-restricted, in vitro-derived CTLs, represented by Clone B6.MI-10.5.4 (12). We later isolated a second CTL clone from in vivo-primed B6 mice, designated Clone B6.MI-9c2, which responded 
to MI B chain p7-15 in the context of $\mathrm{H}-2 \mathrm{D}^{\mathrm{b}}$ (data not shown). Thus, clearly the MI B chain p7-15 peptide can bind efficiently to both $\mathrm{H}-2 \mathrm{~K}^{\mathrm{b}}$ and $\mathrm{H}-2 \mathrm{D}^{\mathrm{b}}$ class $\mathrm{I} \mathrm{MHC}$ molecules. On this basis, we used MI B chain p7-15 as a competitor peptide in competitive inhibition studies to compare the responsiveness of Clone B6.H-4.1c to the $\mathrm{H}-2 \mathrm{~K}^{\mathrm{b}} / \mathrm{cyt} c \mathrm{p} 41-49$ and $\mathrm{H}-2 \mathrm{D}^{\mathrm{b}} / \mathrm{cyt} c \mathrm{p} 41-49$ complexes.

To identify potential anchor residues, we searched both peptide sequences for dominant, strong, or weak anchor residues generally implicated in anchoring peptides to the $\mathrm{H}-2 \mathrm{~K}^{\mathrm{b}}$ and $\mathrm{H}-2 \mathrm{D}^{\mathrm{b}}$ clefts (47). Table I and Table II indicate those amino acids from horse cyt $c$ p41-49 and MI B chain p7-15 that correspond to the peptide-binding motifs (47). These residues are highlighted in bold type for both $H-2 K^{b}$ (Table I) and $H-2 D^{b}$ (Table II) binding. As indicated in Table I, horse cyt $c$ p41-49 contains the dominant anchor, $\mathrm{Phe}^{46}$, at peptide position $\mathrm{p} 6$ of the $\mathrm{H}-2 \mathrm{~K}^{\mathrm{b}}$-binding motif as well as two weak anchor residues, $\mathrm{Pro}^{44}$ and $\mathrm{Thr}^{47}$, at peptide positions $\mathrm{p} 4$ and $\mathrm{p} 7$, respectively. In addition, MI B chain p7-15 contains the $\mathrm{H}-2 \mathrm{~K}^{\mathrm{b}}$-binding motif dominant anchor Leu ${ }^{15}$ at peptide position $\mathrm{p} 9$, and a single weak anchor residue $\mathrm{Glu}^{13}$ at peptide position $\mathrm{p} 7$ (Table I).

The H-2 $\mathrm{D}^{\mathrm{b}}$-binding motif, shown in Table II, reveals that both peptides display a single strong anchor residue as well as three weak anchor residues for binding to $H-2 \mathrm{D}^{\mathrm{b}}$. The horse cyt $c$ p41-49 peptide contains the strong anchor residue, $\mathrm{Phe}^{46}$, at peptide position $\mathrm{p} 6$ and three weak anchor residues, $\mathrm{Gln}^{42}$, $\mathrm{Thr}^{47}$ and $\mathrm{Tyr}^{48}$, at peptide positions $\mathrm{p} 2, \mathrm{p} 7$ and $\mathrm{p} 8$, respectively. The peptide, MI B chain $\mathrm{p} 7-15$, has a strong anchor residue, Pro $^{9}$, at peptide position $\mathrm{p} 3$ plus three weak anchor residues, $\mathrm{Val}^{12}, \mathrm{Glu}^{13}$ and $\mathrm{Leu}^{15}$, at peptide positions $\mathrm{p} 6, \mathrm{p} 7$, and $\mathrm{p} 9$, respectively. Thus both peptides contain a single 
dominant anchor residue for binding to $\mathrm{H}-2 \mathrm{~K}^{\mathrm{b}}$ and a single strong anchor residue for binding to $H-2 D^{b}$. These findings suggest that the peptide-binding affinity for horse cyt $c$ p41-49 and MI B chain p7-15 is similar for the $H-2 K^{b}$ and $H-2 D^{b}$ class I molecules. Thus, MI B chain p7-15 could function as a competitor peptide for binding to both $\mathrm{H}-2 \mathrm{~K}^{\mathrm{b}}$ and $\mathrm{H}-2 \mathrm{D}^{\mathrm{b}}$.

Optimum peptide concentrations are comparable for $H-2 K^{b}$ - and $H-2 D^{b}$-restricted recognition of horse cyt c p41-49 by Clone B6.H-4.1c

An important question concerns whether Clone B6.H-4.1c responds similarly to horse cyt $c$ p $41-49$ in the context of $H-2 K^{b}$ and $H-2 D^{b}$. To address this question, we determined the optimum concentrations of horse cyt $c$ p41-49 peptide needed to lyse ${ }^{51} \mathrm{Cr}$-labeled $\mathrm{L}+\mathrm{K}^{\mathrm{b}}$ and $\mathrm{L}+\mathrm{D}^{\mathrm{b}}$ target cells pulsed with concentrations of horse cyt $c$ p41-49 ranging from $2 \mathrm{pM}$ to $2 \mu \mathrm{M}$ by Clone B6.H-4.1c. The results in Figure 1 and Table III, using Clone B6.H-4.1c at a constant effector-to-target (E:T) ratio of 3:1, show that the optimum horse cyt $c$ p $41-49$ concentration that yields $30 \%$ lysis is $\sim 4 \mathrm{nM}$ for $\mathrm{H}-2 \mathrm{~K}^{\mathrm{b}}$ and $\sim 2 \mathrm{nM}$ for $\mathrm{H}-2 \mathrm{D}^{\mathrm{b}}$. Thus Clone B6.H-4.1c recognizes and lyses both $\mathrm{K}^{\mathrm{b}}$ - and $\mathrm{D}^{\mathrm{b}}$-expressing peptide-pulsed targets with similar efficiency.

MI B chain p7-15 inhibits the response of Clone B6.H-4.1c to both $H-2 K^{b} / c y t$ c p41-49 and $H-2 D^{b} /$ cyt c p $41-49$ complexes

As noted previously, MI B chain p7-15 and horse cyt $c$ p41-49 are similar in their expression of dominant and strong anchor residues for both $\mathrm{H}-2 \mathrm{~K}^{\mathrm{b}}$ and $\mathrm{H}-2 \mathrm{D}^{\mathrm{b}}$ peptidebinding motifs. On this basis we used MI B chain p7-15 in peptide competition 
experiments to compare the relative binding affinities of horse cyt $c$ p41-49 for $\mathrm{H}-2 \mathrm{~K}^{\mathrm{b}}$ and $\mathrm{H}-2 \mathrm{D}^{\mathrm{b}}$ class I molecules. As shown in Figure 2 and Table III, for both $\mathrm{H}-2 \mathrm{~K}^{\mathrm{b}}$ and $\mathrm{H}-2 \mathrm{D}^{\mathrm{b}}$ class I molecules, the addition of the MI B chain $\mathrm{p} 7-15$ competitor peptide results in a significant increase in the concentration of horse cyt $c$ p41-49 target peptide required to yield 30\% lysis by Clone B6.H-4.1c. The addition of $10 \mu \mathrm{M}$ MI B chain $\mathrm{p} 7-15$ causes a $>30$-fold increase and a $>100$-fold increase, respectively, in the concentration of horse cyt $c$ p41-49 required for $30 \%$ lysis of $\mathrm{L}+\mathrm{K}^{\mathrm{b}}$ and $\mathrm{L}+\mathrm{D}^{\mathrm{b}}$ targets by Clone B6.H-4.1c (Table III). Thus MI B chain p7-15 likely binds more efficiently to $H-2 D^{b}$ than to $H-2 K^{b}$.

To confirm this conclusion, we performed RMA-S stabilization experiments, in which horse cyt $c$ p41-49 and MI B chain p7-15 were added separately to RMA-S cells, to determine the levels of $\mathrm{H}-2 \mathrm{~K}^{\mathrm{b}}$ or $\mathrm{H}-2 \mathrm{D}^{\mathrm{b}}$ expression induced by each peptide. We show, in Figure 3, that horse cyt $c$ p41-49 binds efficiently to both class I H-2 ${ }^{\mathrm{b}}$ molecules. Horse cyt $c$ p41-49 and MI B chain p7-15 presented in the context of $\mathrm{H}-2 \mathrm{~K}^{\mathrm{b}}$ reach a steady state at $60 \mathrm{~min}$, demonstrating that the stability of these MHC/peptide complexes are similar. The peptide, MI B chain $\mathrm{p} 7-15$, however, appears to stabilize $\mathrm{H}-2 \mathrm{D}^{\mathrm{b}}$ more readily than horse cyt $c$ p $41-49$ since $H-2 D^{b} / M I ~ p 7-15$ complexes reach a steady state at $120 \mathrm{~min}$ and $\mathrm{H}-2 \mathrm{D}^{\mathrm{b}} / \mathrm{cyt} c \mathrm{p} 41-49$ complexes reach a steady state at $60 \mathrm{~min}$. The lag time of approximately $60 \mathrm{~min}$ in $\mathrm{H}-2 \mathrm{D}^{\mathrm{b}} / \mathrm{MI}$ p7-15 dissociation may account for the $>100$-fold increase in horse cyt $c$ p41-49 required for efficient Clone B6.H-4.1c recognition of $\mathrm{H}-2 \mathrm{D}^{\mathrm{b}} / \mathrm{cyt} c$ p41-49 complexes as demonstrated by peptide competition analysis.

The differences seen between the peptide competition assays, which measure MHC/peptide/TCR interactions, and RMA-S studies, which measure MHC expression, may be explained by the nature of the experiments themselves. On the one hand, peptide 
competition experiments incorporate a degree of sensitivity based on possible differences in both peptide binding to the class I MHC cleft as well as Clone B6.H-4.1c TCR interaction with the distal surface of $\mathrm{H}-2 \mathrm{~K}^{\mathrm{b}} / \mathrm{cyt} c$ p $41-49$ and $\mathrm{H}-2 \mathrm{D}^{\mathrm{b}} / \mathrm{cyt} c$ p41-49 complexes. The RMA-S stabilization studies, however, are based solely on differences in the binding of horse cyt $c$ p41-49 and MI B chain p7-15 in the clefts of $\mathrm{H}-2 \mathrm{~K}^{\mathrm{b}}$ and $\mathrm{H}-2 \mathrm{D}^{\mathrm{b}}$, which alter the stability of the MHC/peptide complexes. In either case, both peptides clearly bind very efficiently to both $\mathrm{H}-2 \mathrm{~K}^{\mathrm{b}}$ and $\mathrm{H}-2 \mathrm{D}^{\mathrm{b}}$ class I molecules and with similar kinetics.

Molecular models predict the interaction of the Clone B6.H-4.1c TCR with $\mathrm{H}-2 \mathrm{~K}^{b} / \mathrm{cyt}$ c p41-49 and $H-2 D^{b} /$ cyt c p $41-49$ complexes

To determine the putative preferred binding configurations for horse cyt $c$ p41-49 in the $\mathrm{H}-2 \mathrm{~K}^{\mathrm{b}}$ and $\mathrm{H}-2 \mathrm{D}^{\mathrm{b}}$ peptide-binding clefts, we developed computer-generated molecular models of the horse cyt $c$ p41-49 peptide bound in the clefts of both class I MHC molecules. These models were generated by a single-step amino acid substitution approach using the x-ray crystal structure coordinates for H-2K $\mathrm{K}^{\mathrm{b}}+\mathrm{SEV}-9(36,37)$ and $\mathrm{H}-2 \mathrm{D}^{\mathrm{b}}+$ influenza A nucleoprotein p366-374 (38) deposited in the Brookhaven Protein Data Bank.

As shown in Figures 4A and 5A, the association of horse cyt $c$ p41-49 with $\mathrm{H}-2 \mathrm{~K}^{\mathrm{b}}$ yields a compact peptide configuration with a clearly distinguishable protruding central region. The amino terminus of horse cyt $c$ p41-49 is anchored in the deep B pocket of the $\mathrm{H}-2 \mathrm{~K}^{\mathrm{b}}$ cleft through interactions with $\mathrm{Gln}^{42}$ at peptide position $\mathrm{p} 2$ (Figure 6 and Table IV). As shown in Figure 6, $\mathrm{Gln}^{42}$ of horse cyt $c$ p41-49 (depicted in blue) forms a single 
hydrogen bond with $\mathrm{Glu}^{63}$ and two bonds with $\mathrm{Asn}^{70}$ located in the B pocket of $\mathrm{H}-2 \mathrm{~K}^{\mathrm{b}}$ (depicted in pink). Although multiple water molecules (depicted in green) are also present in the B pocket, they provide no hydrogen bonding with peptide residues from horse cyt $c$ p41-49.

Conversely, horse cyt $c$ p $41-49$ residues, $\mathrm{Tyr}^{48}$ and $\mathrm{Thr}^{49}$ at peptide positions $\mathrm{p} 8$ and $\mathrm{p} 9$, anchor the carboxyl terminus in the $\mathrm{F}$ pocket of the $\mathrm{H}-2 \mathrm{~K}^{\mathrm{b}}$ antigen-binding cleft by forming complex hydrogen bond networks with water molecules and $\mathrm{H}-2 \mathrm{~K}^{\mathrm{b}}$ residues. As shown in Figure 7 and Table IV, $\mathrm{Tyr}^{48}$ of horse cyt $c$ p41-49 (blue) interacts with $\mathrm{Asp}^{77}$ and Lys ${ }^{146}$ residues, and $\mathrm{Thr}^{49}$ of horse cyt $c$ p41-49 form a single hydrogen bond with the side chain of $\mathrm{Tyr}^{84}$ located in the $\mathrm{F}$ pocket of $\mathrm{H}-2 \mathrm{~K}^{\mathrm{b}}$ (pink). Two hydrogen bonds are also formed between $\mathrm{Thr}^{47}$ and $\mathrm{Tyr}^{48}$ of horse cyt $c \mathrm{p} 41-49$ and may be critical for maintaining the conformation of the $\mathrm{H}-2 \mathrm{~K} / \mathrm{b} / \mathrm{c} c \mathrm{p} 41-49$ complex. Unlike the B pocket, multiple hydrogen bonds are formed between water molecules (green) found in the F pocket and residues $\mathrm{Thr}^{47}$ and $\mathrm{Tyr}^{48}$ of horse cyt $c \mathrm{p} 41-49$. Thus, $\mathrm{Gln}^{42}, \mathrm{Tyr}^{48}$ and $\mathrm{Thr}^{49}$ serve as critical anchor residues for efficient binding of horse cyt $c \mathrm{p} 41-49$ to the cleft of $\mathrm{H}-2 \mathrm{~K}^{\mathrm{b}}$.

The association of horse cyt $c$ p 41-49 with $\mathrm{H}-2 \mathrm{D}^{\mathrm{b}}$ (Figures 4B and 5B) also reveals a bulge at the peptide center. The carboxyl terminus is anchored to the $\mathrm{H}-2 \mathrm{D}^{\mathrm{b}}$ cleft largely through residues $\mathrm{Tyr}^{48}$ and $\mathrm{Thr}^{49}$ (Table IV). The presence of $\mathrm{Tyr}^{48}$ at peptide position $\mathrm{p} 8$ results in the formation of hydrogen bonds with $\mathrm{Gln}^{72}, \mathrm{Val}^{76}$, $\mathrm{Lys}^{146}$ and $\operatorname{Trp}^{147}$ of the $\mathrm{H}-2 \mathrm{D}^{\mathrm{b}}$ cleft. The peptide residue $\mathrm{Thr}^{49}$ forms an additional bond to Lys $^{146}$, as well to $\mathrm{Tyr}^{84}$ and $\mathrm{Thr}^{143}$ residues located in the F pocket of $\mathrm{H}-2 \mathrm{D}^{\mathrm{b}}$ (Table IV). The $H-2 D^{b}$ peptide-binding cleft contains a prominent hydrophobic ridge, consisting of 
$\operatorname{Trp}^{73}, \operatorname{Trp}^{147}, \mathrm{Ala}^{152}$ and $\operatorname{Tyr}^{156}$, that forms between the $\alpha_{1}$ and $\alpha_{2}$ helices and upon which the central region of horse cyt $c$ p41-49 rests (38). As indicated in Table IV, important interactions occur between residues of the $\mathrm{H}-2 \mathrm{D}^{\mathrm{b}}$ hydrophobic ridge and with the carboxyl terminus of horse cyt $c$ p41-49, particularly with residues $\mathrm{Phe}^{46}, \mathrm{Thr}^{47}$ and $\mathrm{Tyr}^{48}$ at peptide positions $\mathrm{p} 6, \mathrm{p} 7$ and $\mathrm{p} 8$. It is likely that these interactions compensate for the absence of strong amino-terminus contacts in facilitating binding of this peptide to $\mathrm{H}-2 \mathrm{D}^{\mathrm{b}}$.

To identify the TCR contact residues important for CTL recognition and response, we analyzed the solvent-accessibility of each computer-generated molecular model using a $1.4 \AA$ surface probe (Figure 5) (32). The side-chain atoms of $\mathrm{Pro}^{44}$ and $\mathrm{Phe}^{46}$ at peptide positions $\mathrm{p} 4$ and $\mathrm{p} 6$, respectively, project outward from the $\mathrm{H}-2 \mathrm{~K}^{\mathrm{b}}$ peptide-binding cleft. They constitute the majority of surface-accessible contacts available for Clone B6.H-4.1c TCR engagement when horse cyt $c$ p41-49 is bound to $\mathrm{H}-2 \mathrm{~K}^{\mathrm{b}}$ (Figure $5 \mathrm{~A}$ and $\mathrm{C}$ ). Likewise, the side chain atoms of $\mathrm{Pro}^{44}, \mathrm{Phe}^{46}$ and $\mathrm{Tyr}^{48}$ at peptide positions p4, p6 and p8 represent the major contact residues available for Clone B6.H-4.1c TCR engagement when horse cyt $c$ p41-49 is bound to $\mathrm{H}^{-2} \mathrm{D}^{\mathrm{b}}$ (Figure $5 \mathrm{~B}$ and D). Thus surfaceaccessibility models suggest that the TCR of Clone B6.H-4.1c utilizes conserved peptide residues for $\mathrm{MHC} /$ peptide complex recognition. 


\section{DISSCUSSION}

The purpose of this study is two-fold: (i) to define the structural relationship between two class I MHC/peptide complexes recognized by dual MHC-restricted CTLs, and (ii) to identify how the Clone B6.H-4.1c TCR interacts functionally with both MHC/peptide complexes. We first examined the single nonamer peptide, horse cyt $c$ p41-49 [G-Q-A-P-G-F-T-Y-T], with respect to how it binds and stabilizes cell-surface expression of $\mathrm{H}-2 \mathrm{~K}^{\mathrm{b}}$ and $\mathrm{H}-2 \mathrm{D}^{\mathrm{b}}$ class I molecules. We then derived computer-generated molecular models to predict the structural relationship between the two MHC/peptide complexes, $\mathrm{H}-2 \mathrm{~K}^{\mathrm{b}} / \mathrm{cyt} c \mathrm{p} 41-49$ and $\mathrm{H}-2 \mathrm{D}^{\mathrm{b}} / \mathrm{cyt} c \mathrm{p} 41-49$. With these molecular models we determined the common surface-accessible areas of both MHC/peptide complexes available for interaction with the TCR of Clone B6.H-4.1c.

To investigate the binding characteristics of horse cyt $c$ p $41-49$ to both $\mathrm{H}-2 \mathrm{~K}^{\mathrm{b}}$ and $H-2 D^{b}$ clefts, we first compared its sequence to the consensus peptide-binding motifs (47) for $\mathrm{H}-2 \mathrm{~K}^{\mathrm{b}}$ (Table I) and $\mathrm{H}-2 \mathrm{D}^{\mathrm{b}}$ (Table II). We showed previously (15) that the nonamer peptide, horse cyt $c$ p $41-49$, is the optimal peptide recognized by $H-2 K^{\mathrm{b}}$ - and $H-2 \mathrm{D}^{\mathrm{b}}$ restricted CTLs. Although this peptide contains a dominant anchor residue plus two weak anchor residues for binding to $\mathrm{H}-2 \mathrm{~K}^{\mathrm{b}}$, and a single strong anchor residue plus three

weak anchor residues for binding to $\mathrm{H}-2 \mathrm{D}^{\mathrm{b}}$, it lacks the complete peptide-binding motif for either $\mathrm{H}-2 \mathrm{~K}^{\mathrm{b}}$ or $\mathrm{H}-2 \mathrm{D}^{\mathrm{b}}$. It is possible that this lack of a complete peptide-binding motif for $\mathrm{H}-2 \mathrm{~K}^{\mathrm{b}}$ or $\mathrm{H}-2 \mathrm{D}^{\mathrm{b}}$ is important for conferring a greater flexibility to the overall binding configurations necessary for the Clone B6.H-4.1c TCR to interact more efficiently with both $\mathrm{MHC} /$ peptide complexes. 
By determining the minimal peptide concentration required for lysis by Clone B6.H-4.1c, we compared its responsiveness to $\mathrm{H}-2 \mathrm{~K}^{\mathrm{b}} / \mathrm{cyt} c \mathrm{p} 41-49$ and $\mathrm{H}-2 \mathrm{D}^{\mathrm{b}} / \mathrm{cyt} c$ p41-49 complexes. The minimal peptide concentrations, defined as the amount of horse cyt $c$ p 41-49 peptide required to yield $30 \%$ lysis of $\mathrm{H}-2 \mathrm{~K}^{\mathrm{b}}$ - or $\mathrm{H}-2 \mathrm{D}^{\mathrm{b}}$-bearing target cells by Clone B6.H-4.1c at an effector-to-target ratio of 3:1, are comparable - approximately $4 \mathrm{nM}$ for $\mathrm{H}-2 \mathrm{~K}^{\mathrm{b}}$ and approximately $2 \mathrm{nM}$ for $\mathrm{H}-2 \mathrm{D}^{\mathrm{b}}$ (Figure 1 and Table III).

These minimal peptide requirements for both $\mathrm{H}-2 \mathrm{~K}^{\mathrm{b}}$ - and $\mathrm{H}-2 \mathrm{D}^{\mathrm{b}}$-restricted recognition by Clone B6.H-4.1c are substantially less than that reported for other CTL clones. Saito and Paterson (39) previously reported that the lytic response for the VSV-8-specific, H-2K ${ }^{\mathrm{b}}$-restricted CTL Clone 33 (48), requires approximately $10 \mathrm{nM}$ of the VSV-8 target peptide, p52-59, to achieve a similar level of lysis. Pease and coworkers (16) showed that the optimal response of the $\mathrm{H}-2 \mathrm{~K}^{\mathrm{b}}$-restricted CTL Clone $2 \mathrm{C}$ requires approximately $100 \mathrm{nM}$ of its target peptide, $\mathrm{dEV}-8$, at an effector-to-target ratio of 2:1. Thus the response of Clone B6.H-4.1c to both $\mathrm{H}-2 \mathrm{~K}^{\mathrm{b}} / \mathrm{cyt} c \mathrm{p} 41-49$ and $\mathrm{H}-2 \mathrm{D}^{\mathrm{b}} / \mathrm{cyt}$ $c$ p41-49 complexes is exquisitely more sensitive to both target MHC/peptide complexes than the response of other CTL clones.

Although the response of Clone B6.H-4.1c to the two MHC/peptide complexes is similar, it is important to determine if differences exist in the stability of peptide binding. This question was addressed by peptide competition experiments (Figure 2 and Table III) with the competitor peptide MI B chain p7-15, which also binds efficiently to both $\mathrm{H}-2 \mathrm{~K}^{\mathrm{b}}$ and $\mathrm{H}-2 \mathrm{D}^{\mathrm{b}}$ (Figure 3). The binding motif for MI B chain $\mathrm{p} 7-15$, which conforms closely to that for horse cyt $c \mathrm{p} 41-49$, raises the possibility that MI B chain $\mathrm{p} 7-15$ binds to both class I MHC molecules with an affinity similar to that for horse cyt $c$ p41-49. 
The peptide competition experiments, summarized in Table III, demonstrated that significantly higher concentrations of horse cyt $c$ p $41-49$ are required to yield $30 \%$ lysis of $\mathrm{H}-2 \mathrm{~K}^{\mathrm{b}}$ - and $\mathrm{H}-2 \mathrm{D}^{\mathrm{b}}$-bearing targets in the presence of $10 \mu \mathrm{M}$ insulin peptide, MI B chain $\mathrm{p} 7-15$. The addition of MI B chain $\mathrm{p} 7-15$ as a competitor peptide results in a $>30$ fold and $>100$-fold increase in the target peptide concentration required for efficient lysis of $\mathrm{L}+\mathrm{K}^{\mathrm{b}}$ and $\mathrm{L}+\mathrm{D}^{\mathrm{b}}$ cells, respectively (Table III).

To address possible differences in the stability of MHC/peptide complexes when horse cyt $c$ p41-49 and MI B chain p7-15 are presented in the context of $\mathrm{H}-2^{\mathrm{b}}$ class I molecules, we performed RMA-S peptide binding studies. As shown in Figure 3, both horse cyt $c$ p41-49 and MI B chain p7-15 dissociate from $\mathrm{H}-2 \mathrm{~K}^{\mathrm{b}}$ and reach a steady state at 60 min when incubated at $37^{\circ} \mathrm{C}$, demonstrating that the stability of $\mathrm{H}-2 \mathrm{~K} /$ cyt $c$ p $41-49$ and $\mathrm{H}-2 \mathrm{~K}^{\mathrm{b}} / \mathrm{MI} \mathrm{p} 7-15$ complexes are comparable. The target peptide, horse cyt $c$ p41-49, also dissociates from $\mathrm{H}-2 \mathrm{D}^{\mathrm{b}}$ and reaches a steady state within 60 min at $37^{\circ} \mathrm{C}$, however, $\mathrm{H}-2 \mathrm{D}^{\mathrm{b}} / \mathrm{MI}$ p7-15 complexes remain stable for up to $120 \mathrm{~min}$. Thus, we conclude that the $>30$-fold and $>100$-fold increase in horse cyt $c$ p41-49 concentrations noted by peptide competition analysis is due to the slower rate of MI B chain p7-15 dissociation from $H-2 D^{b}$.

An alternative consideration is that the Clone B6.H-4.1c TCR might have a higher avidity for $\mathrm{H}-2 \mathrm{~K}^{\mathrm{b}} /$ cyt $c$ p $41-49$ than $\mathrm{H}-2 \mathrm{D}^{\mathrm{b}} /$ cyt $c$ p $41-49$ complexes, thus requiring fewer stable $\mathrm{H}-2 \mathrm{~K}^{\mathrm{b}} / \mathrm{cyt} c \mathrm{p} 41-49$ complexes for recognition. As shown in Figure 1, however, Clone B6.H-4.1c requires comparable concentrations of horse cyt $c$ p41-49 when presented in the context of $\mathrm{H}-2 \mathrm{~K}^{\mathrm{b}}$ and $\mathrm{H}-2 \mathrm{D}^{\mathrm{b}}$ for optimal lysis, $\sim 4 \mathrm{nM}$ and $\sim 2 \mathrm{nM}$, 
respectively. Thus, our findings suggest that the Clone B6.H-4.1c TCR has an avidity that is similar for both $\mathrm{H}-2 \mathrm{~K}^{\mathrm{b}} / \mathrm{cyt} c \mathrm{p} 41-49$ and $\mathrm{H}-2 \mathrm{D}^{\mathrm{b}} / \mathrm{cyt} c \mathrm{p} 41-49$ complexes.

Molecular models generated by interactive graphics programs provide threedimensional structural support for studies involving peptide binding (49-52), MHC/peptide complex stability $(51,53)$ and TCR recognition $(10,49,52)$. QUANTA and CHARMm modeling software packages, described by Nell and coworkers (54) to determine the structure and conformation of mouse insulin monoclonal antibody, designated 125 , were used to generate $\mathrm{H}-2 \mathrm{~K}^{\mathrm{b}} / \mathrm{cyt} c \mathrm{p} 41-49$ and $\mathrm{H}-2 \mathrm{D}^{\mathrm{b}} / \mathrm{cyt} c \mathrm{p} 41-49$ complex molecular models described in this study. X-ray crystal structure-derived coordinates were obtained from the Brookhaven Protein Data Bank (PBD 1vab and 1hoc) and used to generate molecular models that assisted in the evaluation of the peptide configuration of horse cyt $c$ p 41-49 presented in the context $\mathrm{H}-2 \mathrm{~K}^{\mathrm{b}}$ and $\mathrm{H}-2 \mathrm{D}^{\mathrm{b}}$ molecules.

Computer-generated molecular models for horse cyt $c$ p $41-49$ bound to the $\mathrm{H}-2 \mathrm{~K}^{\mathrm{b}}$ peptide binding cleft depict a constricted peptide configuration with a clearly distinguishable central bulge (Figures 4 and 5). It is important to note that although Phe ${ }^{46}$ is predicted to serve as a dominant anchor residue for $\mathrm{H}-2 \mathrm{~K}^{\mathrm{b}}(55)$, this residue is solvent exposed and does not lie buried within the cleft as anticipated (Figures 4 and 5). Instead, $\mathrm{Phe}^{46}$ extends distally from the antigen-binding cleft (Figures $4 \mathrm{C}$ and $5 \mathrm{C}$ ) and thus fails to interact with the class I MHC molecule directly. Similar findings have been reported for the SEV-9 peptide when bound to $\mathrm{H}-2 \mathrm{~K}^{\mathrm{b}}$, indicating that although $\mathrm{H}-2 \mathrm{~K}^{\mathrm{b}}$ molecules traditionally bind octamer peptides, nonamers bind efficiently within the $\mathrm{H}-2 \mathrm{~K}^{\mathrm{b}}$ antigenbinding cleft $(6,36)$. An important feature common to both horse cyt $c$ p41-49 and SEV-9 peptides is the presence of an Ala-Pro-Gly sequence. This combination of AAs, 
particularly Pro-Gly, confer an upward protruding type II $\beta$ bend configuration in the central core of the bound peptide. We propose that this structural feature largely accounts for the efficient binding of horse cyt $c$ p $41-49$ within the $H-2 K^{b}$ cleft $(6,15,36)$ and its recognition by CTL Clone B6.H-4.1c in an $\mathrm{H}-2 \mathrm{~K}^{\mathrm{b}}$-restricted manner.

It appears that the stable association of horse cyt $c$ p $41-49$ to $\mathrm{H}-2 \mathrm{~K}^{\mathrm{b}}$, as with SEV-9, requires a clearly distinguishable peptide segment containing the internal Ala-Pro-Gly sequence. The combination of Pro-Gly forms a type II $\beta$ bend configuration in the secondary structure of the bound peptide that may be necessary for its accommodation within the $\mathrm{H}-2 \mathrm{~K}^{\mathrm{b}}$ antigen-binding cleft. This model has been predicted previously by our lab (15) and others $(6,36)$ and is further supported by the molecular model for the $\mathrm{H}-2 \mathrm{~K}^{\mathrm{b}} / \mathrm{cyt} c$ p41-49 complex presented in this paper (Figures 4 and 5). Likewise, the accommodation of nonamers within the $\mathrm{H}-2 \mathrm{~K}^{\mathrm{b}}$ cleft, although traditionally associated with octamers, has been previously reported based on x-ray crystal structure (23) and biochemical analysis (6).

Several observations in this paper demonstrate that the nonamer, horse cyt $c$ p41-49, is efficiently accommodated within the $\mathrm{H}-2 \mathrm{~K}^{\mathrm{b}}$ binding cleft. First, RMA-S stabilization analysis clearly demonstrates that this peptide binds $\mathrm{H}-2 \mathrm{~K}^{\mathrm{b}}$ with an association and dissociation rate comparable to the self peptide, MI B chain p7-15. Secondly, our molecular models indicate that the formation of hydrogen bond networking between specific $\mathrm{H}-2 \mathrm{~K}^{\mathrm{b}}$ and horse cyt $c$ residues within both the B pocket (Figure 6) and the F pocket (Figure 7). Of particular interest is the presence of water molecules within the $\mathrm{F}$ pocket of $\mathrm{H}-2 \mathrm{~K}^{\mathrm{b}}$ that may provide critical hydrogen bond networking to peptide residues $\mathrm{Thr}^{47}$ and $\mathrm{Tyr}^{48}$ necessary for supporting the central core of horse cyt $c \mathrm{p} 41-49$ 
when bound to $\mathrm{H}-2 \mathrm{~K}^{\mathrm{b}}$ (Figure 7 and Table IV). Smith and coworkers (56), made similar observations for peptides bound to HLA-B53 found that water molecules located beneath peptides within the antigen-binding cleft act to increase the diversity of peptide sequences and aid in peptide stabilization.

Computer-generated molecular models for horse cyt $c$ p41-49 bound to H-2D (Figs. 4B and 5B) reveal the presence of a crucial central peptide bulge due to the insertion of an $\mathrm{Ala}^{43}-\mathrm{Pro}^{44}-\mathrm{Gly}^{45}$ sequence at peptide positions $\mathrm{p} 3, \mathrm{p} 4$, and $\mathrm{p} 5$. The carboxyl terminal residues, $\mathrm{Tyr}^{48}$ and $\mathrm{Thr}^{49}$ at peptide positions $\mathrm{p} 8$ and $\mathrm{p} 9$ (Table IV), serve to anchor the peptide into the cleft. The $\mathrm{H}-2 \mathrm{D}^{\mathrm{b}}$ peptide binding motif (47) strong anchor residue, $\mathrm{Phe}^{46}$, and residues $\mathrm{Thr}^{47}$ and $\mathrm{Tyr}^{48}$ at peptide position $\mathrm{p} 6, \mathrm{p} 7$ and $\mathrm{p} 8$ are directly involved in MHC-peptide stability through intimate contact with the hydrophobic ridge of $\mathrm{H}-2 \mathrm{D}^{\mathrm{b}}$ (Table IV). These interactions facilitate binding of horse cyt $c$ p41-49 to $\mathrm{H}-2 \mathrm{D}^{\mathrm{b}}$ in the absence of strong amino-termini contacts and may explain the rapid rate of dissociation of this peptide from the H-2D $\mathrm{D}^{\mathrm{b}}$ molecule (Figure 3). The type II $\beta$ bend configuration created by Pro $^{44}-\mathrm{Gly}^{45}$ is likely required for binding of horse cyt $c$ p41-49 to $\mathrm{H}-2 \mathrm{D}^{\mathrm{b}}$, thus allowing peptide residues to circumvent steric hindrance forces imposed by the hydrophobic ridge of $\mathrm{H}-2 \mathrm{D}^{\mathrm{b}}$ during $\mathrm{MHC} /$ peptide complex formation and stabilization.

We also determined potential Clone B6.H-4.1c TCR contacts required for recognition of horse cyt $c$ p $41-49$ presented by $\mathrm{H}-2 \mathrm{~K}^{\mathrm{b}}$ and $\mathrm{H}-2 \mathrm{D}^{\mathrm{b}}$ by analyzing solventaccessible peptide residues using a $1.4 \AA$ surface probe (55). $\mathrm{Pro}^{44}$ and $\mathrm{Phe}^{46}$ contribute the majority of $\mathrm{H}-2 \mathrm{~K}^{\mathrm{b}} / \mathrm{cyt} c \mathrm{p} 41-49$ surface-accessible residues available for TCR engagement (Figures 5A and 5C). Likewise, the solvent exposed R groups of Pro ${ }^{44}$, 
$\mathrm{Phe}^{46}$ and to a lesser degree $\mathrm{Tyr}^{48}$ at peptide positions $\mathrm{p} 4, \mathrm{p} 6$ and $\mathrm{p} 8$ constitute the regions of horse cyt $c$ p41-49 available for TCR engagement when bound to H-2 $\mathrm{D}^{\mathrm{b}}$ (Figures 5B and 5D). Collectively, these findings suggest that the Clone B6.H-4.1c TCR interacts with the centrally located solvent-accessible regions of horse cyt $c$ p41-49 - specifically the Pro ${ }^{44}$ and/or Phe ${ }^{46}$ residues - when complexed to $\mathrm{H}-2 \mathrm{~K}^{\mathrm{b}}$ and $\mathrm{H}-2 \mathrm{D}^{\mathrm{b}}$ class I MHC molecules. Of particular interest is the profound similarity between the orientation and extent of surface-accessibility of the Pro ${ }^{44}$ residue at position $\mathrm{p} 4$ when horse cyt $c$ p41-49 is bound to either $\mathrm{H}-2^{\mathrm{b}}$ class I molecules.

We propose that the functional interaction of Clone B6.H-4.1c TCR with both $\mathrm{H}-2 \mathrm{~K} / \mathrm{cyt} c \mathrm{p} 41-49$ and $\mathrm{H}-2 \mathrm{D}^{\mathrm{b}} / \mathrm{cyt} c \mathrm{p} 41-49$ complexes requires an intimate contact with the $\mathrm{Pro}^{44}$ residue at peptide position $\mathrm{p} 4$. In addition, we propose that the $\mathrm{Gly}^{45}$ residue at peptide position $\mathrm{p} 5$ is critical for maintaining the type II $\beta$ bend configuration. An Ala substitution at this position leads to diminished peptide binding, $\mathrm{MHC} /$ peptide stabilization and recognition by Clone B6.H-4.1c. To address these possibilities, we have synthesized peptide analogues of horse cyt $c$ p41-49 containing Ala substitutions at $\mathrm{Pro}^{44}$ or $\mathrm{Gly}^{45}$. In the accompanying manuscript, we compared the response of Clone B6.H-4.1c to native horse cyt $c$ p41-49, versus the horse cyt $c$ p41-49 analogues, designated $\mathrm{p} 41-49 / 44 \mathrm{~A}$ and $\mathrm{p} 41-49 / 45 \mathrm{~A}$, in association with $\mathrm{H}-2 \mathrm{~K}^{\mathrm{b}}$ and $\mathrm{H}-2 \mathrm{D}^{\mathrm{b}}$. 
Table I

The $\mathrm{K}^{\mathrm{b}}$-restricted peptide-binding motif for horse cyt $c$ p41-49 and MI B chain p7-15 residues ${ }^{\mathrm{a}}$

\begin{tabular}{|c|c|c|c|c|c|c|c|c|c|}
\hline & 1 & 2 & 3 & 4 & 5 & 6 & 7 & 8 & 9 \\
\hline Dominant anchor residues & & & & & & $\begin{array}{l}\mathbf{F} \\
\mathrm{Y}\end{array}$ & & & $\mathbf{L}$ \\
\hline Strong anchor residues & & & & $\mathrm{Y}$ & & & & & $\mathrm{M}$ \\
\hline Weak anchor residues & & $\begin{array}{c}\mathrm{R} \\
\mathrm{I} \\
\mathrm{L} \\
\mathrm{S} \\
\mathrm{A} \\
\end{array}$ & $\mathrm{N}$ & $\mathbf{P}$ & $\begin{array}{l}\mathrm{R} \\
\mathrm{D} \\
\mathrm{E} \\
\mathrm{K} \\
\mathrm{T} \\
\end{array}$ & & $\begin{array}{c}\mathbf{T} \\
\mathrm{I} \\
\mathbf{E} \\
\mathrm{S}\end{array}$ & $\begin{array}{l}\mathrm{N} \\
\mathrm{Q} \\
\mathrm{K}\end{array}$ & $\begin{array}{l}\mathrm{I} \\
\mathrm{V}\end{array}$ \\
\hline Horse cyt $c$ p41-49 & G & Q & A & $\mathbf{P}$ & G & $\mathbf{F}$ & $\mathbf{T}$ & $\mathrm{Y}$ & $\mathrm{T}$ \\
\hline MI B chain p7-15 & $\mathrm{C}$ & G & $\mathrm{P}$ & $\mathrm{H}$ & $\mathrm{L}$ & $\mathrm{V}$ & $\mathbf{E}$ & A & $\mathbf{L}$ \\
\hline
\end{tabular}

${ }^{a}$ Anchor residues that correspond to predicted peptide-binding motifs are shown in bold type. 
Table II

The $D^{b}$-restricted peptide-binding motif for horse cyt $c$ p41-49 and MI B chain p7-15 residues ${ }^{\mathrm{a}}$

\begin{tabular}{|c|c|c|c|c|c|c|c|c|c|}
\hline & 1 & 2 & 3 & 4 & 5 & 6 & 7 & 8 & 9 \\
\hline Dominant anchor residues & & & & & $\mathrm{N}$ & & & & M \\
\hline \multirow[t]{4}{*}{ Strong anchor residues } & & M & I & $\mathrm{K}$ & & $\mathrm{L}$ & & & \\
\hline & & & $\mathrm{L}$ & $\mathrm{E}$ & & $\mathbf{F}$ & & & \\
\hline & & & $\mathbf{P}$ & Q & & & & & \\
\hline & & & V & $\mathrm{V}$ & & & & & \\
\hline \multirow[t]{12}{*}{ Weak anchor residues } & A & $\mathrm{A}$ & $\mathrm{G}$ & $\mathrm{D}$ & & A & $\mathrm{D}$ & $\mathrm{F}$ & $\mathbf{L}$ \\
\hline & $\mathrm{N}$ & $\mathbf{Q}$ & & $\mathrm{T}$ & & Y & $\mathbf{E}$ & $\mathrm{H}$ & \\
\hline & I & $\mathrm{D}$ & & & & $\mathrm{T}$ & Q & $\mathrm{K}$ & \\
\hline & $\mathrm{F}$ & & & & & $\mathbf{V}$ & $\mathrm{V}$ & $\mathrm{S}$ & \\
\hline & $\mathrm{P}$ & & & & & M & $\mathbf{T}$ & $\mathbf{Y}$ & \\
\hline & $\mathrm{S}$ & & & & & $\mathrm{E}$ & $\mathrm{Y}$ & & \\
\hline & $\mathrm{T}$ & & & & & Q & & & \\
\hline & $\mathrm{V}$ & & & & & $\mathrm{H}$ & & & \\
\hline & & & & & & $\mathrm{I}$ & & & \\
\hline & & & & & & $\mathrm{K}$ & & & \\
\hline & & & & & & $\mathrm{P}$ & & & \\
\hline & & & & & & $\mathrm{S}$ & & & \\
\hline Horse cyt $c$ p41-49 & G & $\mathbf{Q}$ & A & $\mathrm{P}$ & G & $\mathbf{F}$ & $\mathbf{T}$ & $\mathbf{Y}$ & $\mathrm{T}$ \\
\hline MI B chain p7-15 & $\mathrm{C}$ & $\mathrm{G}$ & $\mathbf{P}$ & $\mathrm{H}$ & $\mathrm{L}$ & $\mathbf{V}$ & $\mathbf{E}$ & A & $\mathbf{L}$ \\
\hline
\end{tabular}

${ }^{\text {a }}$ Anchor residues that correspond to predicted peptide-binding motifs are shown in bold type. 


\section{Table III}

The competitor peptide, MI B chain p7-15, significantly increases the concentration of horse cyt $c$ p41-49 required for Clone B6.H-4.1c recognition.

\begin{tabular}{cccccc}
\hline \hline $\begin{array}{c}\text { Class I } \\
\text { MHC }\end{array}$ & $\begin{array}{c}\text { Target } \\
\text { peptide }\end{array}$ & $\begin{array}{c}\text { Target peptide } \\
\text { concentration }\end{array}$ & $\begin{array}{c}\text { Competitor } \\
\text { peptide }\end{array}$ & $\begin{array}{c}\text { Target peptide } \\
\text { concentration in the } \\
\text { presence of } \\
\text { competitor peptide }\end{array}$ & $\begin{array}{c}\text { Statistical } \\
\text { significance } \\
\text { (p value })^{2}\end{array}$ \\
\hline \hline $\mathrm{H}^{2}-2 \mathrm{~K}^{\mathrm{b}}$ & $\begin{array}{c}\text { Horse cyt } c \\
\mathrm{p} 41-49\end{array}$ & $\sim 4 \mathrm{nM}^{3}$ & $\begin{array}{c}\text { MI B chain } \\
\text { p7-15 }\end{array}$ & $\sim 150 \mathrm{nM}^{3}$ & 0.031 \\
& & & & & \\
$\mathrm{H}^{2}-2 \mathrm{D}^{\mathrm{b}}$ & $\begin{array}{c}\text { Horse cyt } c \\
\mathrm{p} 41-49\end{array}$ & $\sim 2 \mathrm{nM}$ & $\begin{array}{c}\text { M B chain } \\
\text { p7-15 }\end{array}$ & $\sim 230 \mathrm{nM}$ & 0.016 \\
\hline
\end{tabular}

${ }^{1}$ Target peptide concentrations determined as the minimal peptide concentration required to yield 30\% lysis by Clone B6.H-4.1c.

${ }^{2}$ Statistical significance determined by Student's $t$-test comparison of target peptide concentrations in the presence and absence of competitor peptide.

${ }^{3}$ Minimal peptide concentrations are given as the mean of five separate experiments for target peptide concentrations and three separate experiments for peptide competition assays, with an effector-to-target ratio of $3: 1$. 
Table IV

Hydrogen bonds formed between $H-2 K^{b}$ or $H-2 D^{b}$ and horse cyt $c$ p41-49

\begin{tabular}{|c|c|c|c|c|}
\hline $\begin{array}{c}\text { Horse cyt } c \\
\text { p41-49 }\end{array}$ & $\mathrm{H}-2 \mathrm{~K}^{\mathrm{b}}$ & Pocket & $H-2 D^{b}$ & Pocket \\
\hline Gly $^{41}$ & $\mathrm{Tyr}^{7}$ & A & $\operatorname{Tyr}^{171}$ & A \\
\hline $\mathrm{Gln}^{42}$ & $\begin{array}{l}\mathrm{Glu}^{63} \\
\mathrm{Asn}^{70} \\
\mathrm{Asn}^{70}\end{array}$ & $\begin{array}{l}A+B \\
B+C \\
B+C\end{array}$ & $\begin{array}{l}\text { Lys }^{66} \\
\text { P3 Ala }\end{array}$ & B \\
\hline $\mathrm{Ala}^{43}$ & - & - & $\begin{array}{c}\mathrm{HOH} \\
\text { P2 Gln }\end{array}$ & - \\
\hline Pro $^{44}$ & $\begin{array}{l}\operatorname{Arg}^{155} \\
\text { Arg }^{155}\end{array}$ & $\begin{array}{l}D+E \\
D+E\end{array}$ & - & - \\
\hline Gly $^{45}$ & $\begin{array}{l}\mathrm{HOH} \\
\mathrm{HOH} \\
\mathrm{HOH} \\
\mathrm{HOH} \\
\mathrm{HOH}\end{array}$ & - & $\mathrm{G} \ln { }^{70}$ & $\mathrm{~B}+\mathrm{C}$ \\
\hline $\mathrm{Phe}^{46}$ & $\mathrm{HOH}$ & - & $\operatorname{Tyr}^{156}$ & Ridge \\
\hline $\mathrm{Thr}^{47}$ & $\begin{array}{l}\mathrm{HOH} \\
\mathrm{HOH} \\
\mathrm{HOH} \\
\text { P8 Tyr } \\
\text { P8 Tyr }\end{array}$ & - & $\operatorname{Trp}^{73}$ & Ridge \\
\hline Tyr $^{48}$ & $\begin{array}{l}\text { Asp }^{77} \\
\text { Lys }^{146} \\
\text { HOH } \\
\text { HOH } \\
\text { P7 Thr } \\
\text { P7 Thr }\end{array}$ & $\begin{array}{l}\mathrm{F} \\
\mathrm{F}\end{array}$ & $\begin{array}{c}\text { Gln }^{72} \\
\text { Val }^{76} \\
\text { Lys }^{146} \\
\operatorname{Trp}^{147}\end{array}$ & $\begin{array}{c}E+F \\
F \\
F \\
\text { Ridge }\end{array}$ \\
\hline $\mathrm{Thr}^{49}$ & $\begin{array}{c}\text { Tyr }^{84} \\
\text { Thr }^{143} \\
\text { P9 Thr }\end{array}$ & $\begin{array}{l}F \\
F\end{array}$ & $\begin{array}{c}\text { Tyr }^{84} \\
\text { Thr }^{143} \\
\text { Lys }^{146}\end{array}$ & $\begin{array}{l}\mathrm{F} \\
\mathrm{F} \\
\mathrm{F}\end{array}$ \\
\hline
\end{tabular}




\section{FIGURES AND FIGURE LEGENDS}

Fig. 1 Optimum peptide concentrations ${ }^{1}$ are comparable for $H-2 K^{b}$ - and $H-2 D^{b}$ restricted recognition of horse cyt c p41-49 by Clone B6.H-4.1c.

$\mathrm{L}+\mathrm{K}^{\mathrm{b}}(\bullet), \mathrm{L}+\mathrm{D}^{\mathrm{b}}(\boldsymbol{\Delta})$ and $\mathrm{LMTK}^{-}(\boldsymbol{\nabla}){ }^{51} \mathrm{Cr}$-labeled target cells were incubated for 20 min in the presence of varying concentrations $(2 \mathrm{pM}$ to $2 \mu \mathrm{M})$ of target peptide, horse cyt c p41-49. After target peptide incubation, the CTL Clone B6.H-4.1c was added at an effector-to-target ratio of 3:1 for $4 \mathrm{~h}$. Supernatants $(100 \mu \mathrm{l})$ were collected and cytolytic activity was represented as the "percent specific lysis". Spontaneous release of targets in the absence of CTL effectors was $<10 \%$ of maximum lysis by detergent in all experiments. A single representative of five separate experiments is shown.

${ }^{1}$ Minimal peptide concentrations were determined as the peptide concentration required to yield 30\% lysis by Clone B6.H-4.1c. 


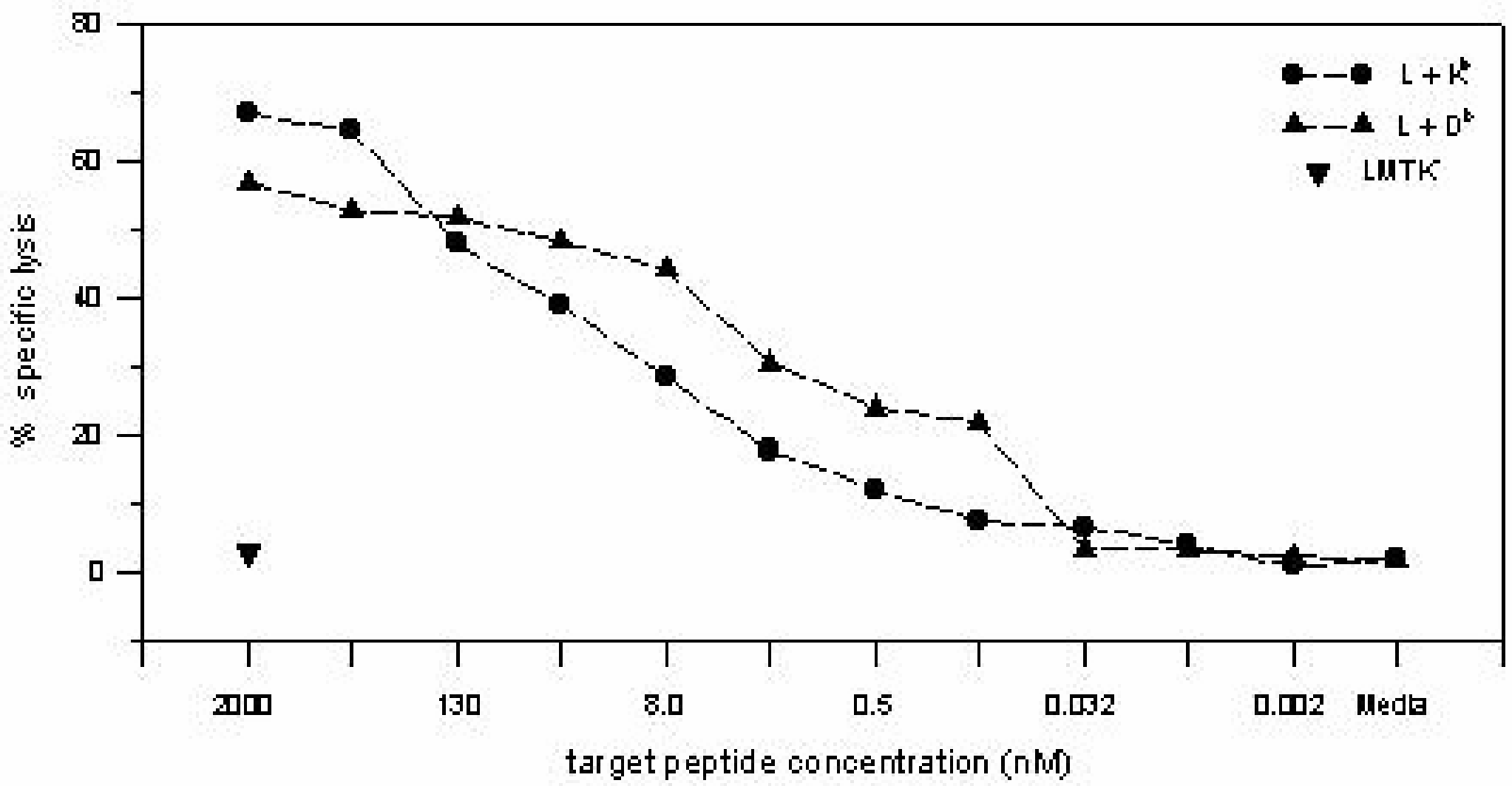


Fig. 2 MI B chain p7-15 inhibits the response of Clone B6.H-4.1c to both $H-2 K^{b} / c y t$ c p41-49 and $H-2 D^{b} /$ cyt c p41-49 complexes.

$\mathrm{L}+\mathrm{K}^{\mathrm{b}}(\bullet)$ and $\mathrm{L}+\mathrm{D}^{\mathrm{b}}(\boldsymbol{\Delta}){ }^{51} \mathrm{Cr}$-labeled target cells were incubated for $20 \mathrm{~min}$ in the presence of varying concentrations $(2 \mathrm{pM}$ to $2 \mu \mathrm{M})$ of target peptide, horse cyt $c$ p41-49, plus the competitor peptide, MI B chain p7-15, at a constant concentration of $10 \mu \mathrm{M}$. Additionally, ${ }^{51} \mathrm{Cr}$-labeled $\mathrm{L}+\mathrm{K}^{\mathrm{b}}$ target cells were incubated with $50 \mathrm{nM}$ of horse cyt $c$ p41-49 (O) or media ( $\square$ ) alone, and acted as positive and negative controls for these experiments. After peptide incubation, Clone B6.H-4.1c was added at an effector-totarget ratio of $3: 1$ for $4 \mathrm{~h}$. Supernatants $(100 \mu \mathrm{l})$ were collected and cytolytic activity was represented as the "percent specific lysis". Spontaneous release of targets in the absence of CTL effectors was $<10 \%$ of maximum lysis by detergent in all experiments. A single representative of three separate experiments is shown. 


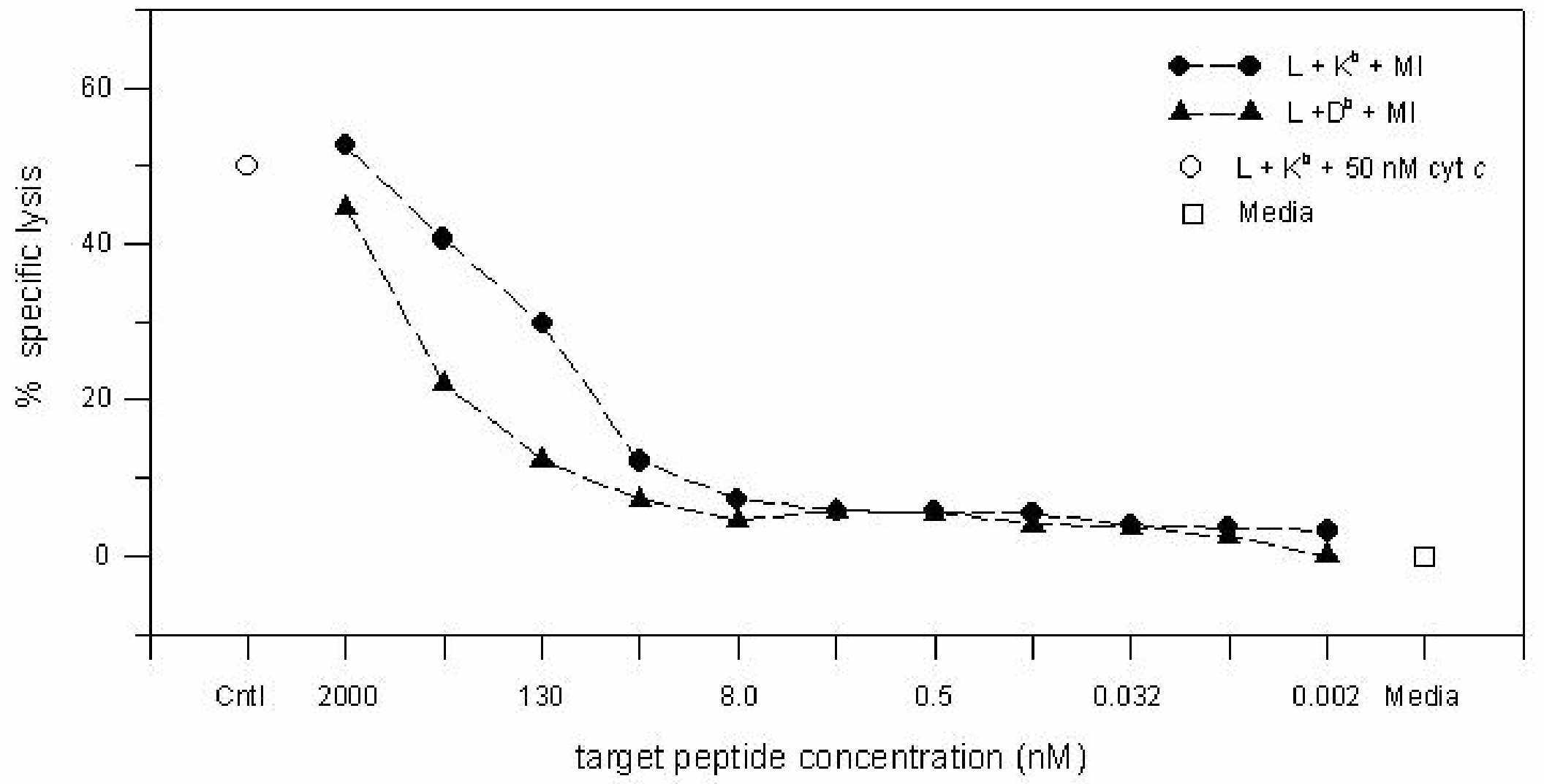


Fig. 3 Horse cyt $c$ p41-49 and MI B chain p7-15 stabilizes the class I MHC molecules, $\mathrm{H}-2 \mathrm{~K}^{\mathrm{b}}$ and $\mathrm{H}-2 \mathrm{D}^{\mathrm{b}}$, with similar kinetics.

$2.5 \times 10^{6}$ RMA-S cells were pulsed with $10 \mu \mathrm{M}$ concentrations of horse cyt $c$ p41-49 (closed), MI B chain p7-15 (open) or media $(\nabla)$ for $1 \mathrm{~h}$ at $30^{\circ} \mathrm{C}, 5 \% \mathrm{CO}_{2}$. Cells were then washed to remove excess unbound peptide and incubated for $0,30,60,120$ and 180 $\min$ at $37^{\circ} \mathrm{C}, 7 \% \mathrm{CO}_{2}$. At each time point, $5 \times 10^{5}$ cells were removed and stained for the presence of stable surface $\mathrm{H}-2 \mathrm{~K}^{\mathrm{b}}(\mathrm{O})$ and $\mathrm{H}-2 \mathrm{D}^{\mathrm{b}}(\Delta)$ molecules. Mean channel fluorescence was determined by flow cytometric analysis and was represented as the fluorescence index as described in Materials and Methods. A single representative of three separate experiments is shown. 


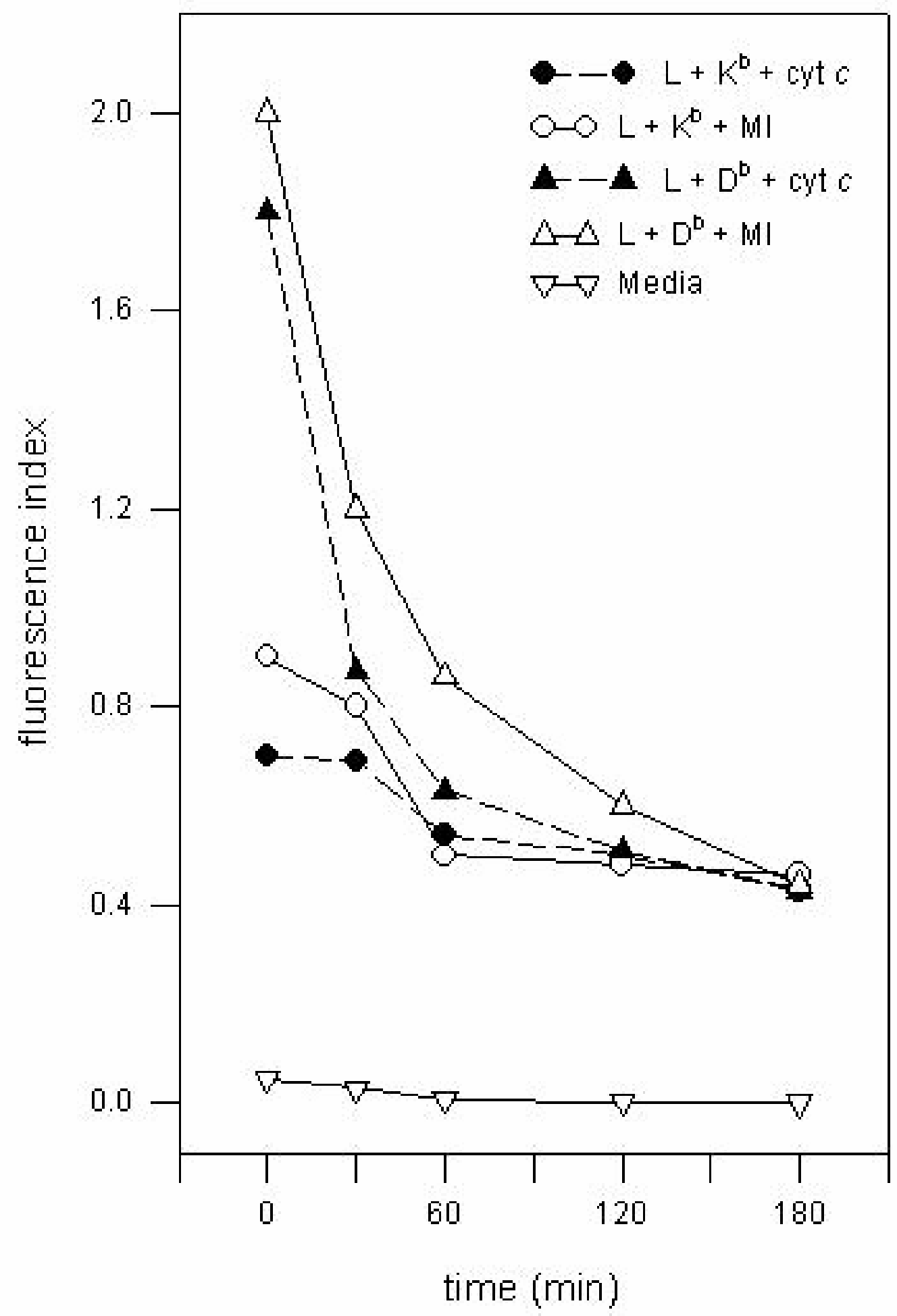


Fig. 4 Horse cyt $c$ p41-49 [G-Q-A-P-G-F-T-Y-T] exhibits a constricted peptide configuration when complexed with $H-2 K^{b}$ and $H-2 D^{b}$.

Horse cyt $c$ p41-49 was introduced into the antigen binding site of $\mathrm{H}-2 \mathrm{~K}^{\mathrm{b}}$ (A and $\mathrm{C}$ ) and $\mathrm{H}-2 \mathrm{D}^{\mathrm{b}}$ (B and D) by single step substitution using $\mathrm{x}$-ray crystal structure coordinates determined for $\mathrm{H}-2 \mathrm{~K}^{\mathrm{b}}$ complexed with SEV-9 (PDB 1vab) and H-2D ${ }^{\mathrm{b}}$ complexed with influenza A p366-374 (PDB 1hoc). Each model is represented as a side view (A and B) and as viewed from above the peptide binding groove (C and D). The class I MHC molecule is represented as a carbon-backbone and bound peptide is denoted by Van der Waals shells. 


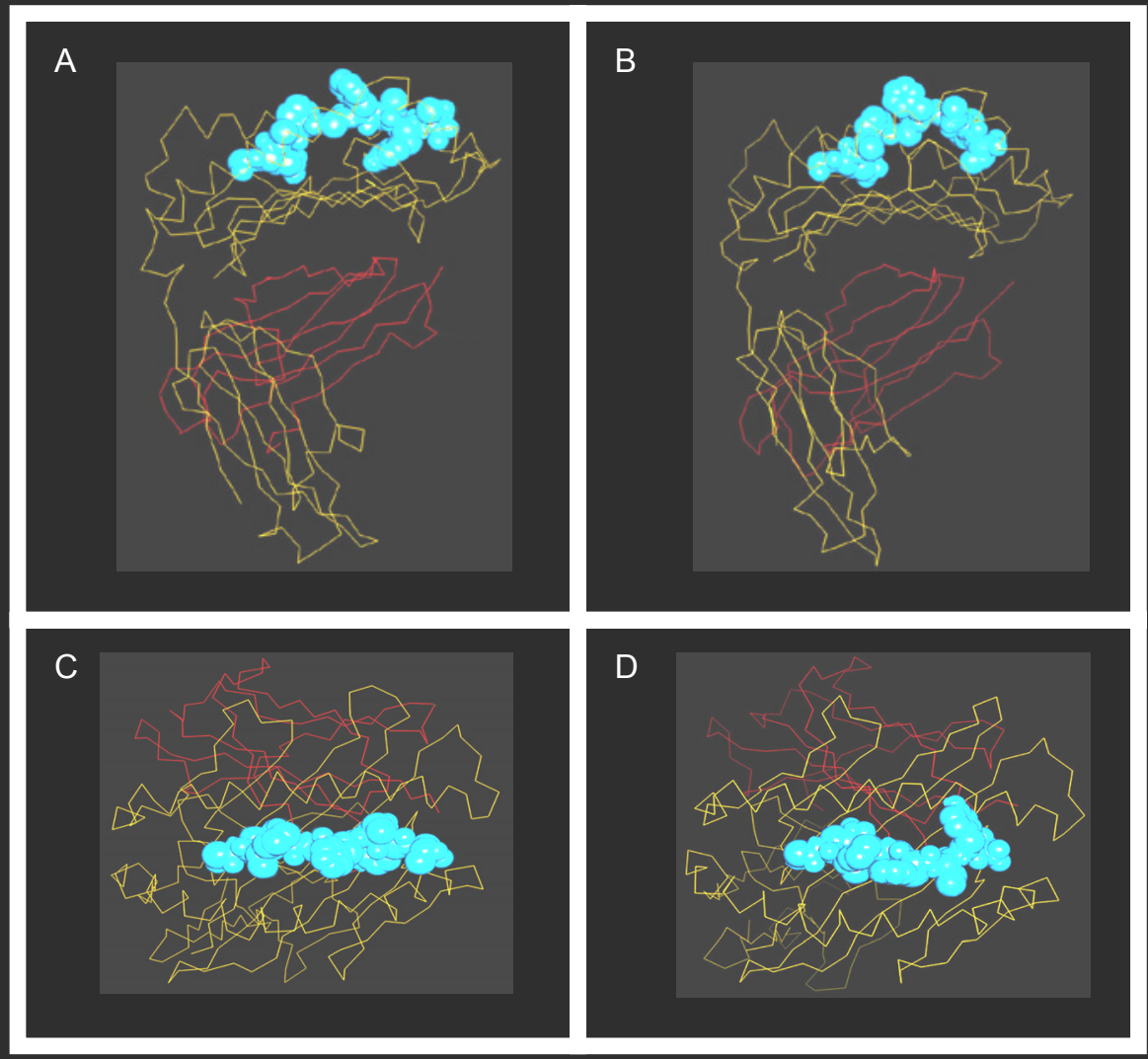


Fig. 5 Pro $^{44}$ at peptide position p4 exhibits similar solvent accessibility and orientation when presented by both $H-2 K^{b}$ and $H-2 D^{b}$.

Solvent accessibility of horse cyt $c$ p41-49 complexed with $\mathrm{H}-2 \mathrm{~K}^{\mathrm{b}}$ (A and C) and H-2D

(B and D) was determined for each molecular model using a $1.4 \AA$ surface probe. Each model is represented as a side view (A and B) and as viewed from above the peptidebinding groove (C and D). Horse cyt $c$ p41-49 residues are individually colored and depicted as Van der Waals shells. Likewise, solvent accessibility for each residue is depicted as surface probe shadowing of the same color. 

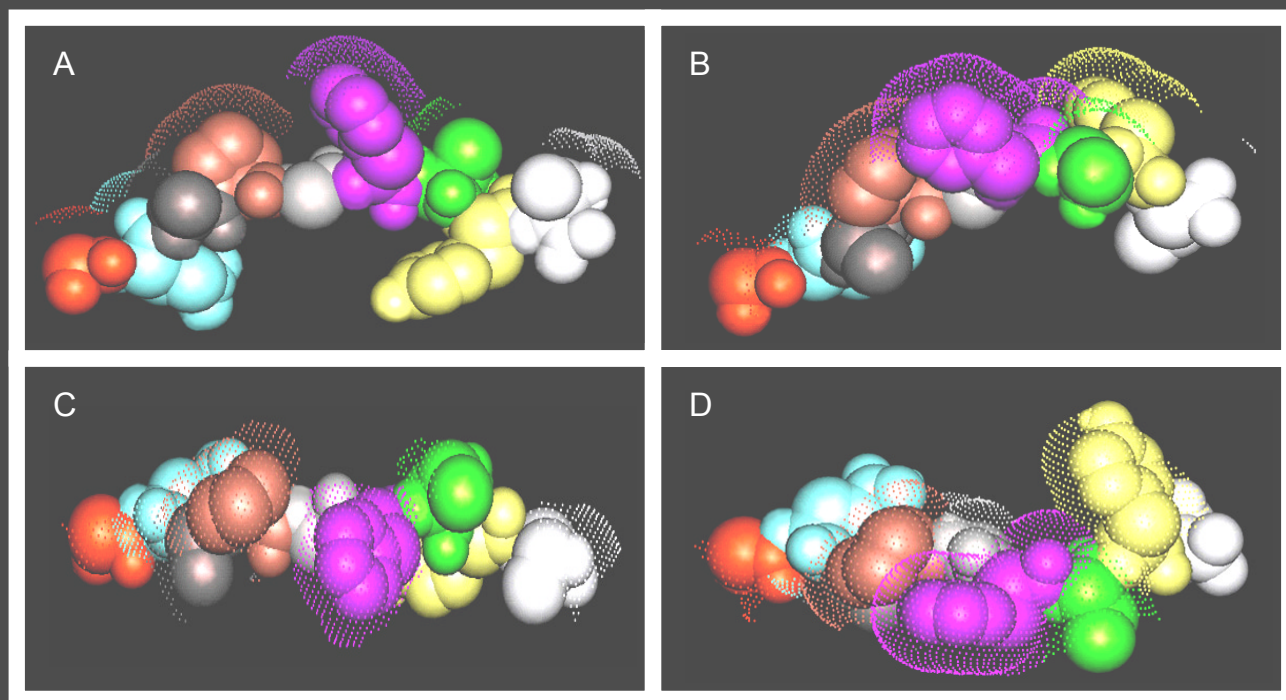
Fig. $6 \mathrm{Gln}^{42}$ at peptide position $\mathrm{p} 2$ anchors the amino terminus of horse cyt $c$ p41-49 in the $B$ pocket of $H-2 K^{b}$.

Hydrogen bond interactions formed between the amino terminus of horse cyt $c$ p41-49 and the $\mathrm{B}$ pocket of $\mathrm{H}-2 \mathrm{~K}^{\mathrm{b}}$ were evaluated for potential peptide anchor residues. Amino terminus residues of horse cyt $c \mathrm{p} 41-49, \mathrm{Gly}^{41}, \mathrm{Gln}^{42}$ and $\mathrm{Ala}^{43}$, are represented in blue, and $\mathrm{H}-2 \mathrm{~K}^{\mathrm{b}}$ residues in the $\mathrm{B}$ pocket are designated in pink. The presence of $\mathrm{G} \mathrm{ln}^{42}$ provides amino terminus anchoring of horse cyt $c$ p $41-49$ to $\mathrm{H}-2 \mathrm{~K}^{\mathrm{b}}$ by forming three hydrogen bonds with $\mathrm{H}-2 \mathrm{~K}^{\mathrm{b}}$ B pocket residues - one with the side chain of $\mathrm{Glu}^{63}$ and two with $\mathrm{Asn}^{70}$. Although water molecules, depicted in green, are present in the B pocket of $\mathrm{H}-2 \mathrm{~K}^{\mathrm{b}}$, they form no hydrogen bonds with peptide residues. 


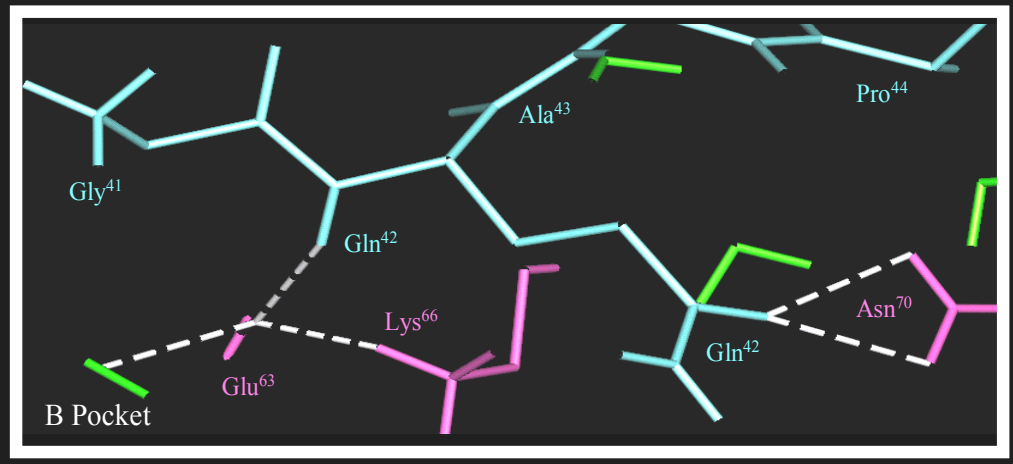


Fig. 7 Complex hydrogen bond networks are formed in the $F$ pocket of $H-2 K^{b}$ to facilitate carboxyl terminus anchoring of horse cyt $c$ p41-49.

Hydrogen bond networking in the F pocket of $\mathrm{H}-2 \mathrm{~K}^{\mathrm{b}}$ was examined to determine peptide anchor residues contributed by the carboxyl terminus of horse cyt $c$ p41-49. Carboxyl terminus residues of horse cyt $c$ p41-49 are represented in blue, F pocket residues of $\mathrm{H}-2 \mathrm{~K}^{\mathrm{b}}$ are depicted in pink, and water molecules in the $\mathrm{F}$ pocket are shown in green. The presence of $\mathrm{Tyr}^{48}$ contributes interactions with Lys ${ }^{146}$ and $\mathrm{Asp}^{77}$ residues in the F pocket of $\mathrm{H}-2 \mathrm{~K}^{\mathrm{b}}$, and also forms two peptide-peptide bonds with $\mathrm{Thr}^{47}$ at peptide position 7 . In addition, $\mathrm{Thr}^{47}$ forms hydrogen bonds with water molecules found in the $\mathrm{F}$ pocket. The peptide residue $\mathrm{Thr}^{49}$ contributes to the carboxyl terminus stabilization of horse cyt $c$ $\mathrm{p} 41-49$ by interacting with the $\mathrm{F}$ pocket residue, $\mathrm{Thr}^{143}$. 


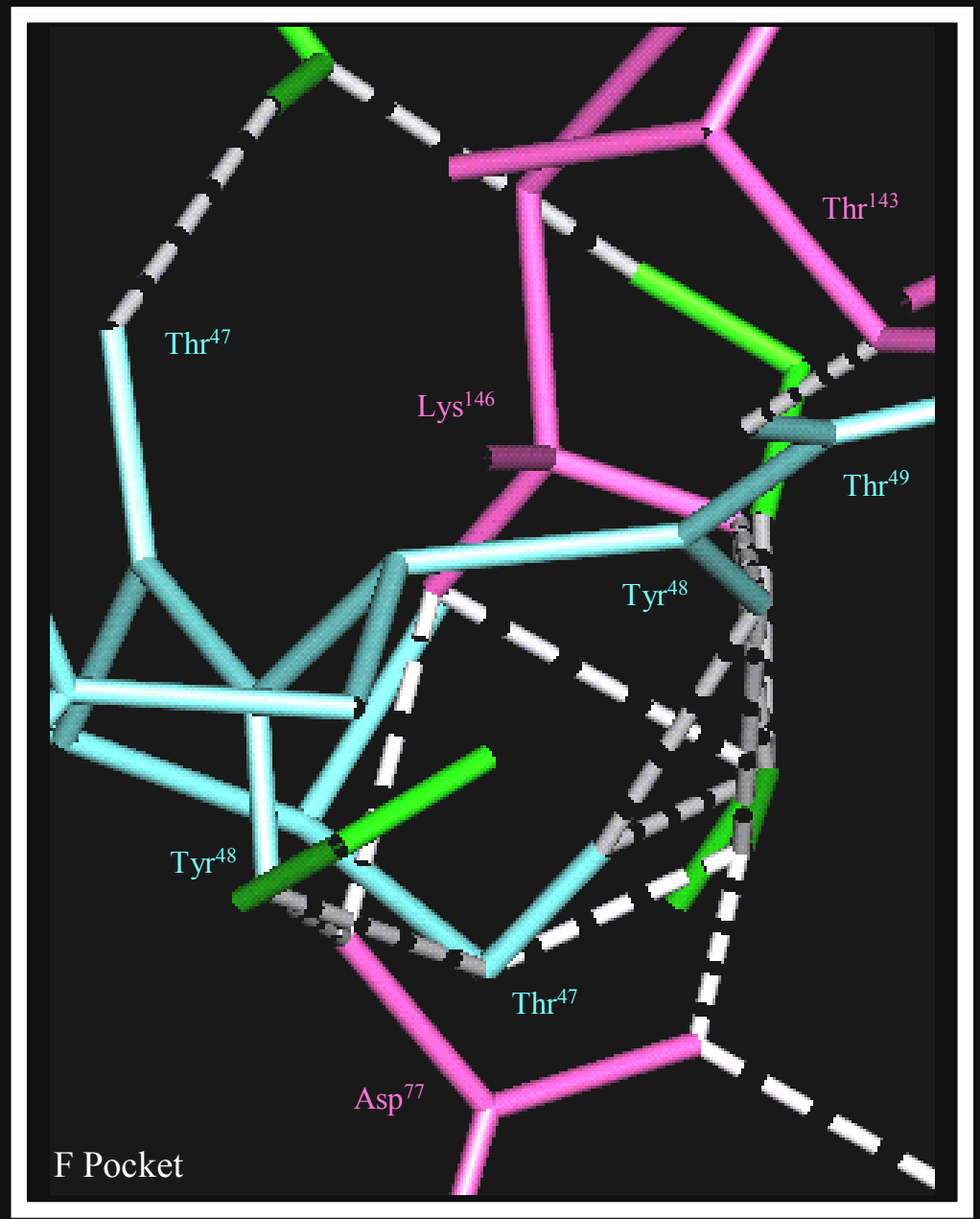




\section{REFERENCES}

1. Bevan, M. J. 1975. The major histocompatibility complex determines susceptibility to cytotoxic $\mathrm{T}$ cells directed against minor histocompatibility antigens. J Exp.Med. $142: 1349-1364$.

2. Bevan, M. J. 1977. Killer cells reactive to altered-self antigens can also be alloreactive. Proc.Natl.Acad.Sci.U.S.A 74:2094-2098.

3. Doherty, P. C. and R. M. Zinernagel. 1975. Capacity of sensitized thymus-derived lymphocytes to induce fatal lymphocytic choriomeningitis is restricted by the H-2 gene complex. J Immunol. 114:30-33.

4. Doherty, P. C. and R. M. Zinkernagel. 1975. Enhanced immunological surveillance in mice heterozygous at the H-2 gene complex. Nature 256:50-52.

5. Zinkernagel, R. M. and P. C. Doherty. 1997. The discovery of MHC restriction. Immunol.Today 18:14-17.

6. Deres, K., T. N. Schumacher, K. H. Wiesmuller, S. Stevanovic, G. Greiner, G. Jung, and H. L. Ploegh. 1992. Preferred size of peptides that bind to $H-2 K^{b}$ is sequence dependent. Eur.J Immunol. 22:1603-1608.

7. Fleischhauer, K., S. Tanzarella, H. J. Wallny, C. Bordignon, and C. Traversari. 1996. Multiple HLA-A alleles can present an immunodominant peptide of the human melanoma antigen Melan-A/MART-1 to a peptide-specific HLA-A*0201 ${ }^{+}$cytotoxic T cell line. J Immunol. 157:787-797. 
8. Johnson, R. P., A. Trocha, T. M. Buchanan, and B. D. Walker. 1992. Identification of overlapping HLA class I-restricted cytotoxic T cell epitopes in a conserved region of the human immunodeficiency virus type 1 envelope glycoprotein: definition of minimum epitopes and analysis of the effects of sequence variation. $J$ Exp.Med. 175:961-971.

9. Oldstone, M. B., A. Tishon, R. Geckeler, H. Lewicki, and J. L. Whitton. 1992. A common antiviral cytotoxic T-lymphocyte epitope for diverse major histocompatibility complex haplotypes: implications for vaccination. Proc.Natl.Acad.Sci.U.S.A 89:2752-2755.

10. Paradela, A., M. Garcia-Peydro, J. Vazquez, D. Rognan, and J. A. Lopez de Castro. 1998. The same natural ligand is involved in allorecognition of multiple HLA-B27 subtypes by a single $\mathrm{T}$ cell clone: role of peptide and the MHC molecule in alloreactivity. J Immunol. 161:5481-5490.

11. Rivoltini, L., D. J. Loftus, K. Barracchini, F. Arienti, A. Mazzocchi, W. E. Biddison, M. L. Salgaller, E. Appella, G. Parmiani, and F. M. Marincola. 1996. Binding and presentation of peptides derived from melanoma antigens MART-1 and glycoprotein100 by HLA-A2 subtypes. Implications for peptide-based immunotherapy. $J$ Immunol. 156:3882-3891.

12. Sheil, J. M., S. E. Shepherd, G. F. Klimo, and Y. Paterson. 1992. Identification of an autologous insulin $\mathrm{B}$ chain peptide as a target antigen for $\mathrm{H}-2 \mathrm{~K}^{\mathrm{b}}$-restricted cytotoxic T lymphocytes. J Exp.Med. 175:545-552. 
13. Shirai, M., M. S. Vacchio, R. J. Hodes, and J. A. Berzofsky. 1993. Preferential V $\beta$ usage by cytotoxic T cells cross-reactive between two epitopes of HIV-1 gp160 and degenerate in class I MHC restriction. J Immunol. 151:2283-2295.

14. Threlkeld, S. C., P. A. Wentworth, S. A. Kalams, B. M. Wilkes, D. J. Ruhl, E. Keogh, J. Sidney, S. Southwood, B. D. Walker, and A. Sette. 1997. Degenerate and promiscuous recognition by CTL of peptides presented by the MHC class I A3-like superfamily: implications for vaccine development. J Immunol. 159:1648-1657.

15. Sheil, J. M., T. D. Schell, S. E. Shepherd, G. F. Klimo, J. M. Kioschos, and Y. Paterson. 1994. Presentation of a horse cytochrome $\mathrm{c}$ peptide by multiple $\mathrm{H}-2^{\mathrm{b}}$ class I major histocompatibility complex (MHC) molecules to C57BL/6- and bm1-derived cytotoxic T lymphocytes: presence of a single MHC anchor residue may confer efficient peptide-specific CTL recognition. Eur.J Immunol. 24:2141-2149.

16. Tallquist, M. D., A. J. Weaver, and L. R. Pease. 1998. Degenerate recognition of alloantigenic peptides on a positive-selecting class I molecule. J Immunol. 160:802809.

17. Kranz, D. M., D. H. Sherman, M. V. Sitkovsky, M. S. Pasternack, and H. N. Eisen. 1984. Immunoprecipitation of cell surface structures of cloned cytotoxic $\mathrm{T}$ lymphocytes by clone-specific antisera. Proc.Natl.Acad.Sci.U.S.A 81:573-577.

18. Tallquist, M. D., T. J. Yun, and L. R. Pease. 1996. A single T cell receptor recognizes structurally distinct $\mathrm{MHC} /$ peptide complexes with high specificity. $J$ Exp.Med. 184:1017-1026. 
19. Walker, J. E., J. M. Arizmendi, A. Dupuis, I. M. Fearnley, M. Finel, S. M. Medd, S. J. Pilkington, M. J. Runswick, and J. M. Skehel. 1992. Sequences of 20 subunits of NADH:ubiquinone oxidoreductase from bovine heart mitochondria. Application of a novel strategy for sequencing proteins using the polymerase chain reaction. $J$ Mol.Biol. 226:1051-1072.

20. Sun, R., S. E. Shepherd, S. S. Geier, C. T. Thomson, J. M. Sheil, and S. G. Nathenson. 1995. Evidence that the antigen receptors of cytotoxic T lymphocytes interact with a common recognition pattern on the $\mathrm{H}-2 \mathrm{~K}^{\mathrm{b}}$ molecule. Immunity. 3:573582.

21. Sant'Angelo, D. B., G. Waterbury, P. Preston-Hurlburt, S. T. Yoon, R. Medzhitov, S. C. Hong, and C. A. Janeway, Jr. 1996. The specificity and orientation of a TCR to its peptide-MHC class II ligands. Immunity. 4:367-376.

22. Davis, M. M. and P. J. Bjorkman. 1988. T-cell antigen receptor genes and T-cell recognition. Nature 334:395-402.

23. Ding, Y. H., K. J. Smith, D. N. Garboczi, U. Utz, W. E. Biddison, and D. C. Wiley. 1998. Two human $\mathrm{T}$ cell receptors bind in a similar diagonal mode to the HLA-A2/Tax peptide complex using different TCR amino acids. Immunity. 8:403411.

24. Garboczi, D. N., P. Ghosh, U. Utz, Q. R. Fan, W. E. Biddison, and D. C. Wiley. 1996. Structure of the complex between human T-cell receptor, viral peptide and HLA-A2. Nature 384:134-141. 
25. Garcia, K. C., M. Degano, L. R. Pease, M. Huang, P. A. Peterson, L. Teyton, and I. A. Wilson. 1998. Structural basis of plasticity in T cell receptor recognition of a self peptide-MHC antigen. Science 279:1166-1172.

26. Jorgensen, J. L., U. Esser, G. B. Fazekas de St, P. A. Reay, and M. M. Davis. 1992. Mapping T-cell receptor-peptide contacts by variant peptide immunization of singlechain transgenics. Nature 355:224-230.

27. Brawley, J. V. and P. Concannon. 1999. Systematic mutagenesis of TCR complementarity-determining region 3 residues: a single conservative substitution dramatically improves response to both multiple HLA-DR alleles and peptide variants. J Immunol. 163:4946-4952.

28. Engel, I. and S. M. Hedrick. 1988. Site-directed mutations in the VDJ junctional region of a $\mathrm{T}$ cell receptor $\beta$ chain cause changes in antigenic peptide recognition. Cell 54:473-484.

29. Manning, T. C., C. J. Schlueter, T. C. Brodnicki, E. A. Parke, J. A. Speir, K. C. Garcia, L. Teyton, I. A. Wilson, and D. M. Kranz. 1998. Alanine scanning mutagenesis of an $\alpha \beta \mathrm{T}$ cell receptor: mapping the energy of antigen recognition. Immunity. 8:413-425.

30. Wedderburn, L. R., S. J. Searle, A. R. Rees, J. R. Lamb, and M. J. Owen. 1995. Mapping $\mathrm{T}$ cell recognition: the identification of a $\mathrm{T}$ cell receptor residue critical to the specific interaction with an influenza hemagglutinin peptide. Eur.J Immunol. 25:1654-1662. 
31. Bowness, P., R. L. Allen, D. N. Barclay, E. Y. Jones, and A. J. McMichael. 1998. Importance of a conserved TCR J $\alpha$-encoded tyrosine for T cell recognition of an HLA B27/peptide complex. Eur.J Immunol. 28:2704-2713.

32. Deng, Y., J. W. Yewdell, L. C. Eisenlohr, and J. R. Bennink. 1997. MHC affinity, peptide liberation, $\mathrm{T}$ cell repertoire, and immunodominance all contribute to the paucity of MHC class I-restricted peptides recognized by antiviral CTL. J Immunol. $158: 1507-1515$.

33. Schumacher, T. N., M. T. Heemels, J. J. Neefjes, W. M. Kast, C. J. Melief, and H. L. Ploegh. 1990. Direct binding of peptide to empty MHC class I molecules on intact cells and in vitro. Cell 62:563-567.

34. Bodmer, H. C., J. M. Bastin, B. A. Askonas, and A. R. Townsend. 1989. Influenzaspecific cytotoxic T-cell recognition is inhibited by peptides unrelated in both sequence and MHC restriction. Immunology 66:163-169.

35. Feltkamp, M. C., M. P. Vierboom, R. E. Toes, F. Ossendorp, J. ter Schegget, C. J. Melief, and W. M. Kast. 1995. Competition inhibition of cytotoxic T-lymphocyte (CTL) lysis, a more sensitive method to identify candidate CTL epitopes than induction of antibody-detected MHC class I stabilization. Immunol.Lett. 47:1-8.

36. Fremont, D. H., M. Matsumura, E. A. Stura, P. A. Peterson, and I. A. Wilson. 1992. Crystal structures of two viral peptides in complex with murine MHC class I H-2 $\mathrm{K}^{\mathrm{b}}$. Science 257:919-927. 
37. Stura, E. A., M. Matsumura, D. H. Fremont, Y. Saito, P. A. Peterson, and I. A. Wilson. 1992. Crystallization of murine major histocompatibility complex class I H-2K ${ }^{\mathrm{b}}$ with single peptides. J Mol.Biol. 228:975-982.

38. Young, A. C., W. Zhang, J. C. Sacchettini, and S. G. Nathenson. 1994. The threedimensional structure of $\mathrm{H}-2 \mathrm{D}^{\mathrm{b}}$ at 2.4 A resolution: implications for antigendeterminant selection. Cell 76:39-50.

39. Saito, N. G. and Y. Paterson. 1997. Contribution of peptide backbone atoms to binding of an antigenic peptide to class I major histocompatibility complex molecule. Mol.Immunol. 34:1133-1145.

40. Ljunggren, H. G., N. J. Stam, C. Ohlen, J. J. Neefjes, P. Hoglund, M. T. Heemels, J. Bastin, T. N. Schumacher, A. Townsend, K. Karre, and . 1990. Empty MHC class I molecules come out in the cold. Nature 346:476-480.

41. Townsend, A., C. Ohlen, J. Bastin, H. G. Ljunggren, L. Foster, and K. Karre. 1989. Association of class I major histocompatibility heavy and light chains induced by viral peptides. Nature 340:443-448.

42. Hammerling, G. J., E. Rusch, N. Tada, S. Kimura, and U. Hammerling. 1982. Localization of allodeterminants on $\mathrm{H}-2 \mathrm{~K}^{\mathrm{b}}$ antigens determined with monoclonal antibodies and H-2 mutant mice. Proc.Natl.Acad.Sci.U.S.A 79:4737-4741.

43. Hasenkrug, K. J., J. M. Cory, and J. H. Stimpfling. 1987. Monoclonal antibodies defining mouse tissue antigens encoded by the H-2 region. Immunogenetics 25:136139. 
44. Shepherd, S. E., R. Sun, S. G. Nathenson, and J. M. Sheil. 1992. Selective reactivity of CD8-independent $\mathrm{T}$ lymphocytes to a cytotoxic $\mathrm{T}$ lymphocyte-selected $\mathrm{H}-2 \mathrm{~K}^{\mathrm{b}}$ mutant altered at position 222 in the $\alpha 3$ domain. Eur.J Immunol. 22:647-653.

45. Levitt, M. and S. Lifson. 1969. Refinement of protein conformations using a macromolecular energy minimization procedure. J Mol.Biol. 46:269-279.

46. Brooks, B. R., R. E. Bruccoleri, B. D. Olafson, D. J. States, S. Swaminathan, and M. Karplus. 1983. CHARMM: A program for macromolecular energy, minimization and dynamic calculations. J.Comput.Chem. 4:187.

47. Falk, K., O. Rotzschke, S. Stevanovic, G. Jung, and H. G. Rammensee. 1991. Allelespecific motifs revealed by sequencing of self-peptides eluted from MHC molecules. Nature 351:290-296.

48. Sheil, J. M., M. J. Bevan, and L. Lefrancois. 1987. Characterization of dual-reactive $\mathrm{H}-2 \mathrm{~K}^{\mathrm{b}}$-restricted anti-vesicular stomatitus virus and alloreactive cytotoxic $\mathrm{T}$ cells. $J$ Immunol. 138:3654-3660.

49. Doherty, D. G., J. E. Penzotti, D. M. Koelle, W. W. Kwok, T. P. Lybrand, S. Masewicz, and G. T. Nepom. 1998. Structural basis of specificity and degeneracy of $\mathrm{T}$ cell recognition: pluriallelic restriction of $\mathrm{T}$ cell responses to a peptide antigen involves both specific and promiscuous interactions between the $\mathrm{T}$ cell receptor, peptide, and HLA-DR. J Immunol. 161:3527-3535.

50. Horig, H., A. C. Young, N. J. Papadopoulos, T. P. DiLorenzo, and S. G. Nathenson. 1999. Binding of longer peptides to the $\mathrm{H}-2 \mathrm{~K}^{\mathrm{b}}$ heterodimer is restricted to peptides 
extended at their $\mathrm{C}$ terminus: refinement of the inherent MHC class I peptide binding criteria. J Immunol. 163:4434-4441.

51. Mata, M., P. J. Travers, Q. Liu, F. R. Frankel, and Y. Paterson. 1998. The MHC class I-restricted immune response to HIV-gag in BALB/c mice selects a single epitope that does not have a predictable MHC-binding motif and binds to $\mathrm{K}^{\mathrm{d}}$ through interactions between a glutamine at P3 and pocket D. J Immunol. 161:2985-2993.

52. Saito, N. G., H. C. Chang, and Y. Paterson. 1999. Recognition of an MHC class Irestricted antigenic peptide can be modulated by para-substitution of its buried tyrosine residues in a TCR-specific manner. J Immunol. 162:5998-6008.

53. Lee, C., M. N. Liang, K. M. Tate, J. D. Rabinowitz, C. Beeson, P. P. Jones, and H. M. McConnell. 1998. Evidence that the autoimmune antigen myelin basic protein (MBP) Ac1-9 binds towards one end of the major histocompatibility complex (MHC) cleft. J Exp.Med. 187:1505-1516.

54. Nell, L. J., J. A. McCammon, and S. Subramaniam. 1992. Anti-insulin antibody structure and conformation. I. Molecular modeling and mechanics of an insulin antibody. Biopolymers 32:11-21.

55. Ding, Y. H., B. M. Baker, D. N. Garboczi, W. E. Biddison, and D. C. Wiley. 1999. Four A6-TCR/peptide/HLA-A2 structures that generate very different $\mathrm{T}$ cell signals are nearly identical. Immunity. 11:45-56.

56. Smith, K. J., S. W. Reid, K. Harlos, A. J. McMichael, D. I. Stuart, J. I. Bell, and E. Y. Jones. 1996. Bound water structure and polymorphic amino acids act together to 
allow the binding of different peptides to MHC class I HLA-B53. Immunity. 4:215228. 


\section{CHAPTER 3}

Dual H-2K $\mathrm{K}^{\mathrm{b}}$ - and H-2D ${ }^{\mathrm{b}}$-Restricted Clonal CTL Recognition of a Horse Cytochrome $c$ Peptide is Dependent on a Critical Pro-Gly Sequence

Marc A. Frankenberry ${ }^{1}$, Todd D. Schell ${ }^{2}$, and James M. Sheil ${ }^{1}$

Department of Microbiology, Immunology \& Cell Biology, West Virginia University

School of Medicine, Morgantown, WV $26506^{1}$ and Microbiology and Immunology, The Pennsylvania State University College of Medicine, Hershey, PA 17033 


\begin{abstract}
In general, a self MHC-restricted $\mathrm{CD}^{+} \mathrm{T}$ lymphocyte responds to a single class I MHC/peptide complex. Studies from several laboratories, however, have demonstrated that some cloned cytotoxic T cells can respond to multiple class I MHC/peptide complex types. We previously showed that CTL Clone B6.H-4.1c is specific for the horse cyt cderived nonamer, cyt $c$ p41-49, presented by either $\mathrm{H}-2 \mathrm{~K}^{\mathrm{b}}$ or $\mathrm{H}-2 \mathrm{D}^{\mathrm{b}}$ class I MHC molecules. We proposed that the Pro $^{44}-\mathrm{Gly}^{45}$ dipeptide sequence serves as a critical contact region for the TCR of Clone B6.H-4.1c. To address this question, we constructed single Ala substitution analogues of the horse cyt $c$ peptide, $\mathrm{p} 41-49$, at peptide positions p4 and p5, designated p41-49/44A and p41-49/45A, respectively. In this paper, we show that the optimal dual $\mathrm{K}^{\mathrm{b}}$ - and $\mathrm{D}^{\mathrm{b}}$-restricted response of Clone B6.H-4.1c is critically dependent on the presence of both Pro $^{44}$ and $\mathrm{Gly}^{45}$ in the core region of this peptide. Although the p41-49/44A analogue binds as well to both $\mathrm{H}-2 \mathrm{~K}^{\mathrm{b}}$ and $\mathrm{H}-2 \mathrm{D}^{\mathrm{b}}$ as the native p41-49 peptide, recognition of both $\mathrm{K}^{\mathrm{b}} / \mathrm{p} 41-49 / 44 \mathrm{~A}$ and $\mathrm{D}^{\mathrm{b}} / \mathrm{p} 41-49 / 44 \mathrm{~A}$ complexes by CTL Clone B6.H-4.1c is ablated. The p41-49/45A analogue, when presented by either $\mathrm{H}-2 \mathrm{~K}^{\mathrm{b}}$ or $\mathrm{H}-2 \mathrm{D}^{\mathrm{b}}$, can only elicit cytolysis by Clone B6.H-4.1c at significantly higher peptide concentrations than the native peptide. Computer-generated molecular models for horse cyt $c$ p41-49, and analogues p41-49/44A and p41-49/45A, binding to $\mathrm{H}-2 \mathrm{~K}^{\mathrm{b}}$ and $\mathrm{H}-2 \mathrm{D}^{\mathrm{b}}$, demonstrate that disruption of the type II $\beta$ bend formed by Pro ${ }^{44}-\mathrm{Gly}^{45}$ alters the configuration of peptide residues essential for engaging the TCR.
\end{abstract}




\section{INTRODUCTION}

$\mathrm{CD}^{+}$cytotoxic $\mathrm{T}$ lymphocytes $(\mathrm{CTL})$ respond to short antigenic peptides presented in the context of a single self class I major histocompatibility complex (MHC) molecule (1-5). A number of studies demonstrate, however, that certain CTLs do not strictly adhere to this dogma of "self MHC-restriction" (6-12). We previously reported that CTL Clone B6.H-4.1c is specific for the horse cytochrome $c$ (cyt c)-derived nonamer, p41-49, presented in the context of $\mathrm{H}-2 \mathrm{~K}^{\mathrm{b}}$ and $\mathrm{H}-2 \mathrm{D}^{\mathrm{b}}$, as well as the mutant $\mathrm{H}-$ $2 \mathrm{~K}^{\mathrm{bm} 1}$, class I MHC molecules (9 and Frankenberry et al, manuscript submitted). Likewise, Pease and coworkers (11) showed that CTL Clone 2C is specific for the self peptide, $\mathrm{dEV}-8$, in association with $\mathrm{H}-2 \mathrm{~K}^{\mathrm{b}}$ and its closely related mutant, $\mathrm{H}-2 \mathrm{~K}^{\mathrm{bm} 3}$. In addition, Clone $2 \mathrm{C}$ also responds to a second peptide, designated $\mathrm{p} 2 \mathrm{Ca}$, in the context of either $\mathrm{H}-2 \mathrm{~K}^{\mathrm{b}}$ or $\mathrm{H}-2 \mathrm{~L}^{\mathrm{d}}(10)$.

Our understanding of the nature of degenerate $\mathrm{T}$ cell recognition involves several components. First, the MHC/peptide/T cell receptor (TCR) trimolecular complex interaction during thymic selection is somewhat promiscuous $(13,14)$. Developing $\mathrm{T}$ cells undergo positive selection in the thymus based on how well they interact with self MHC/peptide complexes (15-17). Certain evidence supports the suggestion that thymic selection plays an important role in the induction of inherently degenerate $\mathrm{T}$ cell responses. Kappler and Marrack (18) observed that a single peptide can select a wide range of $\mathrm{T}$ cells expressing various TCRs. Thymic selection plays an important role in the development of inherently degenerate $\mathrm{T}$ cell responses, given that a single TCR is 
confronted with a diverse pool of peptides during the positive and negative selection process (19).

A second important feature of degenerate $\mathrm{T}$ cell recognition is the plasticity of the secondary structure of the TCR during its engagement with MHC/peptide complexes. Plasticity, in this report, refers to changes in orientation of the complementaritydetermining regions (CDR) of the TCR engaged with a $\mathrm{MHC} /$ peptide complex, as described previously (20). We and Nathenson's group (21) initially characterized the orientation of the TCR to the class I MHC/peptide distal surface by analyzing the cytolytic response of alloreactive CTLs to a panel of $\mathrm{H}-2 \mathrm{~K}^{\mathrm{b}}$ mutant cell lines. This study demonstrated that the TCR is oriented diagonally across the distal surface of the class I MHC/peptide complex. Similarly, Janeway and coworkers (22) also observed that T cells responding to class II MHC/peptide complexes interact in a diagonal orientation, with the TCR variable $\alpha\left(\mathrm{V}_{\alpha}\right)$ domain aligned over the peptide amino terminus and the TCR $V_{\beta}$ domain aligned over the carboxyl terminus of the peptide. Several other studies describing the three-dimensional $\mathrm{x}$-ray crystallographic structure for MHC/peptide/TCR trimolecular complexes confirm this diagonal orientation of the TCR with respect to the MHC/peptide complex (20,23-25).

The third component of degenerate $\mathrm{T}$ cell recognition indicates that TCR engagement with $\mathrm{MHC} /$ peptide complexes requires contact with specific peptide residues. The $\mathrm{x}$-ray crystal structure analysis of the $\mathrm{H}-2 \mathrm{~K}^{\mathrm{b}} / \mathrm{dEV}-8 / 2 \mathrm{C}$ (25) and HLA-A2/Tax ${ }_{11-19} / \mathrm{A} 6$ (24) trimolecular complexes revealed that the TCR is aligned directly over the central peptide core region of class I MHC-bound peptides. Joyce and coworkers (26) demonstrated that a $\mathrm{H}-2 \mathrm{~K}^{\mathrm{b}}$-restricted, minor histocompatibility $(\mathrm{H}) \mathrm{H}-4^{\mathrm{b}}$ - 
specific CTL clone recognizes only peptides within combinatorial libraries that contain an invariant, solvent-accessible isoleucine residue at peptide position p6. They also found that the $\mathrm{H}-2 \mathrm{~K}^{\mathrm{b}}$-restricted, herpes simplex virus (HSV)-I glycoprotein B (gB)specific CTL clone, Clone 2D5, recognizes only those peptides that contain glutamic acid at peptide position $\mathrm{p} 4\left(\mathrm{Glu}^{4}\right)$. These observations suggest that few TCR-accessible peptide contact residues are necessary for antigen-specific recognition by the TCR of $\mathrm{CD} 8^{+}$CTL clones.

We recently demonstrated (9) that in the horse cyt $c$ p41-49 peptide, residues Pro $^{44}$ and $\mathrm{Gly}^{45}$ form a type II $\beta$ bend that contributes to formation of both $\mathrm{H}-2 \mathrm{~K}^{\mathrm{b}} / \mathrm{cyt} c$ p41-49 and $\mathrm{H}-2 \mathrm{D}^{\mathrm{b}} / \mathrm{cyt} c \mathrm{p} 41-49$ complexes and to their recognition by the $\mathrm{CD} 8^{+} \mathrm{CTL}$ Clone B6.H-4.1c. Ploegh and coworkers $(27,28)$ showed that the Sendai virus nucleoprotein p324-332 (SEV-9) also binds efficiently to and stabilizes both $\mathrm{H}-2 \mathrm{~K}^{\mathrm{b}}$ and $\mathrm{H}-2 \mathrm{D}^{\mathrm{b}}$ molecules; the primary sequence of this peptide is [F-A-P-G-N-Y-P-A-L]. This nonamer stabilizes $\mathrm{H}-2 \mathrm{~K}^{\mathrm{b}}$ molecules at concentrations comparable to that of other $\mathrm{H}-2 \mathrm{~K}^{\mathrm{b}}$ restricted octamer peptides, including the endogenously processed vesicular stomatitis virus nucleoprotein peptide p52-59 (VSV-8) [R-G-Y-V-Y-Q-G-L] and the ovalbumin (OVA)-derived peptide, $\mathrm{OVA}_{257-264}$ [S-I-I-N-F-E-K-L] (27). The authors propose that the presence of Pro and Gly residues in tandem induces certain conformational constraints that allow binding of the nonamer peptide to $\mathrm{H}-2 \mathrm{~K}^{\mathrm{b}}$ (27). Thus, it is likely that the Pro-Gly dipeptide combination introduces a type II $\beta$ bend into the peptide secondary structure that facilitates its binding to MHC class I molecules by allowing the peptide backbone to protrude out of from the antigen-binding cleft. We propose that the dual $\mathrm{H}-2 \mathrm{~K}^{\mathrm{b}}$ - and $\mathrm{H}-2 \mathrm{D}^{\mathrm{b}}$-restricted recognition of horse cyt $c$ p41-49 by Clone B6.H-4.1c is 
critically dependent on the prominent Pro $^{44}$-Gly ${ }^{45}$-induced type II $\beta$ bend found in the horse cyt $c$ p41-49 peptide. To address this possibility, we use horse cyt $c$ p41-49 peptide analogues consisting of a single alanine (Ala) substitution, P44A or G45A, at peptide positions $\mathrm{p} 4$ or $\mathrm{p} 5$, respectively. 


\section{MATERIALS AND METHODS}

\section{Animals}

Female C57BL/6 (B6) mice used in this study were obtained from this laboratory's breeding colony at West Virginia University Health Sciences Center Vivarium. The B6 colony was established in 1987 and has been maintained since then at the West Virginia University Health Sciences Center Vivarium. All mice used in this study were between 8 and 12 weeks of age.

\section{Target cell lines}

Transfected cell lines were derived from a thymidine kinase-negative $\mathrm{L}$ cell $\left(\mathrm{H}-2^{\mathrm{k}}\right)$ fibroblast line (designated $\mathrm{LMTK}^{-}$) and grown as adherent cultures in RPMI-1640 media supplemented with 10\% FCS, $100 \mathrm{mM}$ HEPES, $100 \mathrm{U} / \mathrm{ml}$ penicillin, $100 \mu \mathrm{g} / \mathrm{ml}$ streptomycin and $2 \mathrm{mM}$ L-glutamine (RP-10), as previously described (9). These transfected cell lines, which include $\mathrm{L}+\mathrm{K}^{\mathrm{b}}$ and $\mathrm{L}+\mathrm{D}^{\mathrm{b}}$, were kindly provided by Drs. $\mathrm{S}$. G. Nathenson and R. Zeff. Appropriate H-2 ${ }^{b}$ class I expression was verified by flow cytometry in our laboratory (data not shown).

\section{Synthesis of peptides}

The peptides, horse cyt $c$ p41-49 [G-Q-A-P-G-F-T-Y-T], analogue p41-49/44A [G-Q-AA-G-F-T-Y-T], analogue p41-49/45A [G-Q-A-P-A-F-T-Y-T] and mouse insulin I B chain (MI) p7-15 [C-G-S-H-V-E-A-L], were generously provided by Drs. J. W. Yewdell, J. R. Bennink and T. Schell. Peptides were synthesized by fMoc chemistry using an 
automated peptide synthesizer (9050 MilliGen PepSynthesizer), as previously described (29). Amino acid composition and purity was determined by HPLC tracing (Waters 600E) and the Pico Tag Amino Acid Analysis System (Waters). Lyophilized peptides were solubilized in sterile 1X PBS at appropriate stock concentrations. For the purpose of peptide competition studies, we used horse cyt $c$ p41-49 and its analogue p41-49/45A as target peptides; the analogue $\mathrm{p} 41-49 / 44 \mathrm{~A}$ and $\mathrm{MI} \mathrm{B}$ chain $\mathrm{p} 7-15$ were used as competitor peptides.

\section{RMA-S stabilization assays}

The method for peptide-induced stabilization of RMA-S cells has been described previously (30,31). Briefly, the B6-derived, transporter associated with antigen processing (TAP)-deficient, murine cell line RMA-S $(32,33)$ was grown initially in RP10 media in a humidified incubator at $37^{\circ} \mathrm{C}$ with $7 \% \mathrm{CO}_{2}$. RMA-S cells $\left(2.5 \times 10^{6}\right)$ were transferred to $30^{\circ} \mathrm{C}$ in $5 \% \mathrm{CO}_{2}$ for $18-20 \mathrm{~h}$ to induce stable $\mathrm{H}-2 \mathrm{~K}^{\mathrm{b}}$ and $\mathrm{H}-2 \mathrm{D}^{\mathrm{b}}$ expression. RMA-S cells were then washed twice with 1X PBS containing 2\% FCS and $0.01 \%$ sodium azide (PBS-2\%) and incubated with $10 \mu \mathrm{M}$ of horse cyt $c$ p41-49, analogue p4149/44A, analogue p41-49/45A or MI B chain p7-15 for one hour. Peptide-pulsed RMA-S cells were then washed twice with PBS- $2 \%$ to remove excess unbound peptide, resuspended in RP-10 media, and incubated in a humidified incubator at $37^{\circ} \mathrm{C}, 7 \% \mathrm{CO}_{2}$. RMA-S cells $\left(5 \times 10^{5}\right)$ were incubated with PE-conjugated anti-H-2 $\mathrm{K}^{\mathrm{b}}$ or anti-H-2D monoclonal antibodies (mAbs) and analyzed by flow cytometry at $0,30,60,120$ and 180 $\min$. 


\section{Antibodies and flow cytometry}

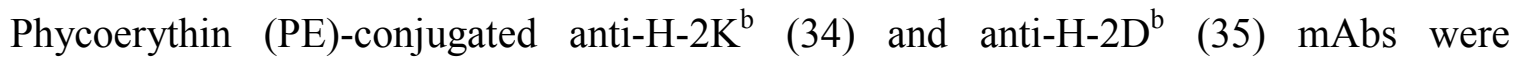
purchased from Caltag Laboratories ${ }^{\circledR}$ (Burlingame, CA). Peptide-pulsed RMA-S cells (5 $\left.\mathrm{X} 10^{5}\right)$ were incubated for 45 minutes on ice with $20 \mu \mathrm{l}$ of appropriate mAb (1:20) and washed twice with PBS-2\%. RMA-S cells $\left(1 \times 10^{5}\right)$ were analyzed for fluorescence intensity using a FACScan ${ }^{\circledR}$ flow cytometer (Becton Dickinson, Mountain View, CA). The mean channel fluorescence (MCF) indicates the mean channel number of fluorescence, detected from 10,000 gated cells. The fluorescence index was calculated as previously determined (36), using the following formula:

(MCF in the presence of peptide) - (MCF in the absence of peptide)

(MCF in the absence of peptide)

\section{CTL Clone B6.H-4.1c}

Maintenance of the CTL clone, Clone B6.H-4.1c, has been previously described (9). Briefly, 4 X $10^{5}$ Clone B6.H-4.1c CTLs were incubated in a 24-well flat-bottom plate with $5 \times 10^{6}$ irradiated (2000 rads) B6 spleen cells plus $2 \mu \mathrm{M}$ horse cyt $c$ p41-49 suspended in RP-10 media. Clone B6.H-4.1c CTLs were analyzed for lytic reactivity after four days and subsequently re-stimulated on the seventh day. 


\section{${ }^{51}$ Cr-release assay}

The lytic activity of Clone B6.H-4.1c was assayed in vitro using a standard $4-\mathrm{h}{ }^{51} \mathrm{Cr}$ release assay (21). Briefly, 1 X $10^{6}$ LMTK-, $\mathrm{L}+\mathrm{K}^{\mathrm{b}}$ and $\mathrm{L}+\mathrm{D}^{\mathrm{b}}$ target cells were incubated in a $50 \mu \mathrm{l}$ volume of RP-10 media plus $100 \mu \mathrm{Ci}$ sodium chromate $51\left({ }^{51} \mathrm{Cr}\right.$; New England Nuclear, Boston, MA) per 1 X $10^{6}$ cells for 60 min at $37^{\circ} \mathrm{C}, 7 \% \mathrm{CO}_{2}$, washed in 1X HBSS and resuspended in $10 \mathrm{ml}$ RP-10. Following an additional $30 \mathrm{~min}$ incubation in a $37^{\circ} \mathrm{C}$ water bath, target cells were washed in $1 \mathrm{X}$ HBSS and resuspended in RP-10 media at a final concentration of 2 X $10^{5}$ cells $/ \mathrm{ml}$. Target cells were added in a volume of $50 \mu \mathrm{l} /$ well to 96 -well round-bottom microtiter plates. Exogenous peptides to be tested were added at a volume of $50 \mu \mathrm{l} /$ well with a final concentration of $2 \mu \mathrm{M}$ and incubated for $20 \mathrm{~min}$ at $37^{\circ} \mathrm{C}, 7 \% \mathrm{CO}_{2}$. Effector CTLs, Clone B6.H-4.1c, were added at a volume of $100 \mu \mathrm{l} /$ well with the following effector-to-target ratios: $30: 1,10: 1,3: 1$ and 1:1. Cells were incubated for $4 \mathrm{~h}$ at $37^{\circ} \mathrm{C}, 7 \% \mathrm{CO}_{2}$, then the assay plates were centrifuged for $7 \mathrm{~min}$ at $1200 \mathrm{rpm}$. Supernatants $(100 \mu \mathrm{l})$ were collected from each well and transferred to 6 X $50 \mathrm{~mm}$ tubes for determination of total ${ }^{51} \mathrm{Cr}$ counts on an LKB Clinigamma Model 1272 counter (LKB Instruments, Finland). The "percent specific lysis" was determined as follows:

$\frac{\text { experimental cpm - spontaneous cpm }}{\text { maximum cpm - spontaneous cpm }} \times 100$

Spontaneous release values in the absence of CTL effectors was $<10 \%$ of maximum lysis by detergent in all experiments. 


\section{Minimal peptide concentration determination}

Final volume peptide concentrations ranging from $2 \mathrm{pM}$ to $2 \mu \mathrm{M}$ for the native horse cyt c p41-49, analogue p41-49/44A or analogue p41-49/45A were added to ${ }^{51} \mathrm{Cr}$-labeled target cells and incubated for $20 \mathrm{~min}$ at $37^{\circ} \mathrm{C}, 7 \% \mathrm{CO}_{2}$. Clone B6.H-4.1c effector CTLs were added at a volume of $100 \mu \mathrm{l} /$ well with a constant effector-to-target ratio of 3:1. Cells were incubated for $4-\mathrm{h}$ at $37^{\circ} \mathrm{C}, 7 \% \mathrm{CO}_{2}$ and the assay plates were centrifuged for 7 min at $1200 \mathrm{rpm}$ and $100 \mu \mathrm{l}$ of supernatant was collected from each well. Minimal peptide concentrations were determined as the peptide concentration required to yield $30 \%$ lysis at an effector-to-target ratio of 3:1.

\section{Peptide competition inhibition assays}

Competition inhibition assays have been described previously (36). Briefly, a constant competitor peptide concentration was added to the target peptide concentrations ranging from $2 \mathrm{pM}$ to $2 \mu \mathrm{M}$. The target peptides (horse cyt $c \mathrm{p} 41-49$ or analogue $\mathrm{p} 41-49 / 45 \mathrm{~A}$ ) and competitor peptides (analogue p41-49/44A or MI B chain $\mathrm{p} 7-15$ ) were added to ${ }^{51} \mathrm{Cr}$ labeled target cells and incubated for $20 \mathrm{~min}$ at $37^{\circ} \mathrm{C}, 7 \% \mathrm{CO}_{2}$. Effector CTLs, Clone B6.H-4.1c, were added at a volume of $50 \mu \mathrm{l} /$ well with a constant effector-to-target ratio of 3:1. Cells were incubated for $4 \mathrm{~h}$ at $37^{\circ} \mathrm{C}, 7 \% \mathrm{CO}_{2}$, and the assay plates were centrifuged for $7 \mathrm{~min}$ at $1200 \mathrm{rpm}$ and $100 \mu \mathrm{l}$ of supernatant was collected from each well. The degree of competitor peptide inhibition was determined by a Student's $t$-test comparison of the target peptide concentration required to yield $30 \%$ lysis at an effectorto-target ratio of 3:1 in the presence and absence of competitor peptide. 


\section{Computer modeling}

To investigate horse cyt $c$ 41-49, analogue p41-49/44A and analogue p41-49/45A binding to class I MHC molecules and T cell recognition, these peptides were introduced into the peptide-binding cleft of $\mathrm{H}-2 \mathrm{~K}^{\mathrm{b}}$ and $\mathrm{H}-2 \mathrm{D}^{\mathrm{b}}$ molecules. Molecular models were generated using a Silicon Graphics UNIX-based computer with QUANTA/CHARMm software designed by Molecular Simulations, Inc. X-ray crystal structure coordinates for the H$2 \mathrm{~K}^{\mathrm{b}}$ complexed with the Sendai virus nucleoprotein (SEV-9) p324-332 [F-A-P-G-N-Y-PA-L] $(37,38)$ and $H-2 D^{b}$ complexed with the influenza A p366-374 [A-S-N-E-N-M-E-TM] (39) were obtained from the Brookhaven Protein Data Bank (PBD 1vab and 1hoc). QUANTA/CHARMm software was utilized to introduce horse cyt $c$ p41-49, analogue $\mathrm{p} 41-49 / 44 \mathrm{~A}$ and analogue $\mathrm{p} 41-49 / 45 \mathrm{~A}$ into the parental $\mathrm{H}-2 \mathrm{~K}^{\mathrm{b}}$ and $\mathrm{H}-2 \mathrm{D}^{\mathrm{b}} \mathrm{x}$-ray crystal structure by replacing a single amino acid residue, followed by 50 cycles of regularization at the steepest descent and 200 cycles of the adopted basis set NewtonRaphson (ABNR) method. The peptide sequences were regularized after each single amino acid residue replacement to reduce unfavorable bonds and angles. To minimize the energy configuration, the completed $\mathrm{MHC}$ /peptide complexes were subjected to 100 cycles of CHARMm minimization using the ABNR method.

\section{Statistical analysis}

All statistics in this study were performed by a paired, one-tailed Student's $t$-test. Statistical significance, were indicated, was determined as $\mathrm{p}<0.05$. 


\section{RESULTS}

Clone B6.H-4.1c recognizes the horse cyt c p41-49 analogue p41-49/45A, but not analogue p41-49/44A, when presented by $H-2 K^{b}$ and $H-2 D^{b}$ molecules

The purpose of this report is to investigate the role of the type II $\beta$ bend contributed by the dipeptide sequence, Pro ${ }^{44}-\mathrm{Gly}^{45}$, in Clone B6.H-4.1c recognition of $\mathrm{H}-2 \mathrm{~K}^{\mathrm{b}} / \mathrm{cyt} \mathrm{c}$ p $41-49$ and $\mathrm{H}-2 \mathrm{D}^{\mathrm{b}} / \mathrm{cyt} \mathrm{c}$ p $41-49$ complexes. To accomplish this aim, we constructed two horse cyt c p41-49 peptide analogues each containing a single Ala substitution, $\mathrm{P} 44 \mathrm{~A}$ or $\mathrm{G} 45 \mathrm{~A}$, at peptide positions $\mathrm{p} 4$ and $\mathrm{p} 5$, respectively. We used these analogues, designated $\mathrm{p} 41-49 / 44 \mathrm{~A}$ and $\mathrm{p} 41-49 / 45 \mathrm{~A}$, to evaluate the responsiveness of Clone B6.H-4.1c to MHC/peptide complexes following disruption of the type II $\beta$ bend. $\mathrm{L}+\mathrm{K}^{\mathrm{b}}, \mathrm{L}+\mathrm{D}^{\mathrm{b}}$ and $\mathrm{LMTK}^{-}$target cells were labeled with ${ }^{51} \mathrm{Cr}$ and pre-incubated with 2 $\mu \mathrm{M}$ concentrations of horse cyt c p41-49, analogue $\mathrm{p} 41-49 / 44 \mathrm{~A}$ or the analogue p41-49/45A prior to the addition of Clone B6.H-4.1c effector cells. As shown in Figure 1, Clone B6.H-4.1c recognizes analogue p41-49/45A but not analogue p41-49/44A on both $\mathrm{H}-2 \mathrm{~K}^{\mathrm{b}}$ or $\mathrm{H}-2 \mathrm{D}^{\mathrm{b}}$. Likewise, Clone B6.H-4.1c does not lyse peptide free target cells or the $\mathrm{H}-2^{\mathrm{k}}$-bearing target cell line, LMTK: Clone B6.H-4.1c recognition of analogue p41-49/45A is comparable to both $\mathrm{H}-2 \mathrm{~K}^{\mathrm{b}} / \mathrm{cyt}$ c p41-49 and $\mathrm{H}-2 \mathrm{D}^{\mathrm{b}} / \mathrm{cyt}$ c p41-49 suggesting that the single amino acid substitution (G45A) at peptide position $\mathrm{p} 5$ does not affect responsiveness at $2 \mu \mathrm{M}$ concentrations. The single amino acid substitution (P44A) at peptide position $\mathrm{p} 4$ does, however, disrupt Clone B6.H-4.1c recognition. One possible explanation for this lack of responsiveness by Clone B6.H-4.1c is that the horse cyt c 
analogue, p41-49/44A, may either fail to associate with, or rapidly dissociation from, $\mathrm{H}-2 \mathrm{~K}^{\mathrm{b}}$ and $\mathrm{H}-2 \mathrm{D}^{\mathrm{b}}$ class I MHC molecules.

Native horse cyt c p41-49 and the analogues, p41-49/44A and p41-49/45A, stabilize expression of class I MHC molecules, $H-2 K^{b}$ and $H-2 D^{b}$

To determine the residues important for antigen binding to $H-2 K^{b}$ and $H-2 D^{b}$ class I molecules, we applied the published peptide-binding motifs to the horse cyt $c$ p41-49 analogues, p41-49/44A and p41-49/45A (40). As shown in Table I, H-2K binding for both horse cyt $c$ p41-49 analogues is predicted to involve a single dominant anchor, $\mathrm{Phe}^{46}$, and a weak anchor residue, $\mathrm{Thr}^{47}$, at peptide positions 6 and 7 , respectively. Although the weak anchor Pro $^{44}$ at peptide position p4 is present in analogue p41-49/45A, this residue has been replaced with an Ala in analogue p41-49/44A, and thus its absence may adversely affect $\mathrm{H}-2 \mathrm{~K}^{\mathrm{b}}$ binding and presentation. Those residues that contribute to the binding of both peptide analogues to $H-2 \mathrm{D}^{\mathrm{b}}$ (Table II) are identical to those in the native peptide; they are the single strong anchor residue, $\mathrm{Phe}^{46}$, and the three weak anchor residues, $\mathrm{Glu}^{42}, \mathrm{Thr}^{47}$ and $\mathrm{Tyr}^{48}$. Thus, binding of the peptide analogues, p41-49/44A and $\mathrm{p} 41-49 / 45 \mathrm{~A}$, to $\mathrm{H}-2 \mathrm{D}^{\mathrm{b}}$ is likely to be comparable to that of native horse cyt $c$ p $41-49$.

We also determined which MI B chain p7-15 peptide residues contribute to its binding to $\mathrm{H}-2 \mathrm{~K}^{\mathrm{b}}$ and $\mathrm{H}-2 \mathrm{D}^{\mathrm{b}}$ class I molecules (Table I and II). As previously described (Frankenberry et al, manuscript submitted), MI B chain p7-15 also binds to both $\mathrm{H}-2 \mathrm{~K}^{\mathrm{b}}$ and $\mathrm{H}-2 \mathrm{D}^{\mathrm{b}}$ class I MHC molecules and is recognized by the $\mathrm{H}-2 \mathrm{~K}^{\mathrm{b}}$ - and $\mathrm{H}-2 \mathrm{D}^{\mathrm{b}}$-specific CTL clones, Clone B6.MI-9c2 and Clone B6.MI-10.5.2, respectively (8). The native MI 
B chain p7-15 peptide contains a single dominant anchor and a single weak anchor residue for $\mathrm{H}-2 \mathrm{~K}^{\mathrm{b}}$ binding, as well as a single strong anchor and three weak anchor residues for binding to $\mathrm{H}-2 \mathrm{D}^{\mathrm{b}}$. Thus, both horse cyt $c$ analogue, p41-49/44A, and MI B chain p7-15 appear to be capable of binding efficiently to either $\mathrm{H}-2^{\mathrm{b}}$ class I molecule.

To determine whether the peptide analogue p41-49/44A form stable MHC/peptide complexes with $\mathrm{H}-2 \mathrm{~K}^{\mathrm{b}}$ and $\mathrm{H}-2 \mathrm{D}^{\mathrm{b}}$, RMA-S stabilization assays were performed utilizing native horse cyt $c \mathrm{p} 41-49$, analogue $\mathrm{p} 41-49 / 44 \mathrm{~A}$ and analogue $\mathrm{p} 41-49 / 45 \mathrm{~A}$. As shown in Figure 2, analogue p41-49/44A stabilize $H-2 K^{b}$ and $H-2 D^{b}$ molecules in a manner comparable to that of native horse cyt $c$ p41-49. Analogue p41-49/45A exhibits the highest binding efficiency for $\mathrm{H}-2 \mathrm{~K}^{\mathrm{b}}$ and maintains stable $\mathrm{H}-2 \mathrm{~K}^{\mathrm{b}}$ expression for up to $3 \mathrm{~h}$ when incubated at $37^{\circ} \mathrm{C}$. Analogue $\mathrm{p} 41-49 / 45 \mathrm{~A}$ disassociates rapidly, however, from $\mathrm{H}-2 \mathrm{D}^{\mathrm{b}}$ molecules and after 2 hours few stable MHC/peptide complexes are expressed at the cell surface. These findings demonstrate that native horse cyt $c$ p41-49, analogue $\mathrm{p} 41-49 / 44 \mathrm{~A}$ and analogue $\mathrm{p} 41-49 / 45 \mathrm{~A}$ bind to and stabilize both $\mathrm{H}-2 \mathrm{~K}^{\mathrm{b}}$ and $\mathrm{H}-2 \mathrm{D}^{\mathrm{b}}$ molecules and that each peptide is presented to Clone B6.H-4.1c effector CTLs. Thus, the lack of responsiveness by Clone B6.H-4.1c for analogue p41-49/44A is not due to deficient MHC/peptide complex formation.

Significantly higher analogue p41-49/45A peptide concentrations are required for optimal target cell lysis by Clone B6.H-4.1c

To quantitate the lytic response of Clone B6.H-4.1c for $\mathrm{H}-2 \mathrm{~K}^{\mathrm{b}}$ and $\mathrm{H}-2 \mathrm{D}^{\mathrm{b}}$ molecules associated with either native horse cyt c p41-49 or the analogue p41-49/45A, minimal peptide concentration studies were performed. Target cells expressing $\mathrm{H}-2 \mathrm{~K}^{\mathrm{b}}$ 
and $\mathrm{H}-2 \mathrm{D}^{\mathrm{b}}$ molecules were labeled with ${ }^{51} \mathrm{Cr}$ and pre-incubated with $2 \mathrm{pM}$ to $2 \mu \mathrm{M}$ concentrations of the target peptide native horse cyt c p41-49, analogue p41-49/44A or analogue p41-49/45A. Clone B6.H-4.1c effector cells, at an effector-to-target ratio of 3:1, were added for $4 \mathrm{~h}$ to determine peptide-specific lytic activity. As described previously (Frankenberry et al, manuscript submitted), optimal lytic function was determined by the minimal peptide concentration, defined as the amount of peptide required to yield $30 \%$ target cell lysis by Clone B6.H-4.1c CTL effectors. As demonstrated in Figures 1 and 3, the p41-49/44A analogue fails to induce a cytolytic response from Clone B6.H-4.1c when presented by either $\mathrm{H}-2 \mathrm{~K}^{\mathrm{b}}$ or $\mathrm{H}-2 \mathrm{D}^{\mathrm{b}}$ molecules. Clone B6.H-4.1c recognition of p41-49/45A requires significantly higher peptide concentrations than native horse cyt $\mathrm{c}$ p41-49 for both $\mathrm{H}-2 \mathrm{~K}^{\mathrm{b}}$ and $\mathrm{H}-2 \mathrm{D}^{\mathrm{b}}$ molecules (Figure 3 and Table III). A minimal peptide concentration of $\sim 4 \mathrm{nM}$ and $\sim 2 \mathrm{nM}$ is required for Clone B6.H-4.1c recognition of native horse cyt c p41-49 presented by $\mathrm{H}-2 \mathrm{~K}^{\mathrm{b}}$ and $\mathrm{H}-2 \mathrm{D}^{\mathrm{b}}$, respectively. Recognition of the $\mathrm{p} 41-49 / 45 \mathrm{~A}$ peptide analogue bound to $\mathrm{H}-2 \mathrm{~K}^{\mathrm{b}}$ and $\mathrm{H}-2 \mathrm{D}^{\mathrm{b}}$ requires a minimal peptide concentration of $\sim 125 \mathrm{nM}$ and $\sim 80 \mathrm{nM}$, respectively, suggesting it binds with a lower affinity than $\mathrm{p} 41-49 / 44 \mathrm{~A}$ to both $\mathrm{K}^{\mathrm{b}}$ and $\mathrm{D}^{\mathrm{b}}$.

Recognition of native horse cyt c p41-49 and analogue p41-49/44A is inhibited by the competitor peptides, MI B chain p7-15 and p41-49/45A

To determine the lytic capacity of the Clone B6.H-4.1c response to the $\mathrm{H}-2 \mathrm{~K}^{\mathrm{b}}$ and $\mathrm{H}-2 \mathrm{D}^{\mathrm{b}}$ molecules associated with native horse cyt c p41-49 or p41-49/45A, peptide competition experiments were performed with MI B chain p7-15 and the horse cyt c analogue p41-49/44A as competitor peptides. As shown in Figure 4, target cells were co- 
incubated with native horse cyt c p41-49, ranging from $2 \mathrm{pM}$ to $2 \mu \mathrm{M}$, plus $10 \mu \mathrm{M}$ of either MI B chain p7-15 or p41-49/44A for 20 min. Clone B6.H-4.1c effectors were then added at an effector-to-target ratio of 3:1 and lytic activity was determined after $4 \mathrm{~h}$. As shown in Figure 4 and Table III, the addition of $10 \mu \mathrm{M}$ MI B chain p7-15 results in a $>30$-fold and $>100$-fold increase in the concentration of native horse cyt c p41-49 peptide required for optimal lysis of $\mathrm{H}-2 \mathrm{~K}^{\mathrm{b}}$ - and $\mathrm{H}-2 \mathrm{D}^{\mathrm{b}}$-bearing target cells, respectively. Furthermore, the addition of $10 \mu \mathrm{M}$ p41-49/44A as a competitor significantly increases the concentration of native horse cyt c p41-49 peptide required for $\mathrm{H}-2 \mathrm{~K}^{\mathrm{b}}$ - and $\mathrm{H}-2 \mathrm{D}^{\mathrm{b}}$ restricted lysis by approximately 6 -fold and 12 -fold, respectively. Thus, the introduction of either competitor peptide significantly increases the concentration of native horse cyt $\mathrm{c}$ p41-49 required for optimal target cell lysis.

To ascertain the lytic capacity of Clone B6.H-4.1c for the analogue p41-49/45A, target cells were co-incubated with $2 \mathrm{pM}$ to $2 \mu \mathrm{M}$ concentrations of $\mathrm{p} 41-49 / 45 \mathrm{~A}$ and a $100 \mathrm{nM}$ concentration of either MI B chain $\mathrm{p} 7-15$ or p41-49/44A for 20 minutes. Again, positive and negative internal controls were included for each experiment and consisted of target cells pre-incubated with $50 \mathrm{nM}$ of analogue p41-49/45A or media in the absence of competitor peptides. As shown in Figure 5 and Table III, approximately 7-fold and 15-fold higher concentrations of analogue p41-49/45A are required for optimal target lysis when $\mathrm{H}-2 \mathrm{~K}^{\mathrm{b}}$ - and $\mathrm{H}-2 \mathrm{D}^{\mathrm{b}}$-bearing target cells were co-incubated with $100 \mathrm{nM}$ MI B chain $\mathrm{p} 7-15$. The addition of $100 \mathrm{nM}$ p41-49/44A analogue results in a significant $(\sim 3-$ fold) increase in the concentration of analogue p41-49/45A required for optimal lysis of $\mathrm{H}-2 \mathrm{D}^{\mathrm{b}}$-bearing target cells (Figure 5 and Table III). This competitor peptide, p41-49/44A, does not significantly increase the concentration of analogue p41-49/45A 
required for $\mathrm{H}-2 \mathrm{~K}^{\mathrm{b}}$-restricted lysis. This may be due to enhanced stabilization of $\mathrm{H}-2 \mathrm{~K}^{\mathrm{b}} / \mathrm{p} 41-49 / 45 \mathrm{~A}$ complexes when compared to analogue p41-49/44A (Figure 2).

Essential TCR contacts with horse cyt c p41-49 are disrupted by the single amino acid substitution $\left(\right.$ Pro $^{44} \rightarrow$ Ala), thus ablating Clone B6.H-4.1c cytolysis

To determine whether critical TCR-peptide contacts are disrupted following single amino acid substitution, (P44A) and (G45A), computer-generated molecular models of $\mathrm{H}-2 \mathrm{~K}^{\mathrm{b}}$ and $\mathrm{H}-2 \mathrm{D}^{\mathrm{b}}$ associated with native $\mathrm{p} 41-49$, $\mathrm{p} 41-49 / 44 \mathrm{~A}$ or $\mathrm{p} 41-49 / 45 \mathrm{~A}$ were constructed. Each peptide was introduced into the antigen-binding cleft of the x-ray crystal structure for H-2K ${ }^{b}$ complexed with the SEV-9 [F-A-P-G-N-Y-P-A-L] $(37,38)$ or H-2D ${ }^{b}$ complexed with influenza A p366-374 [A-S-N-E-N-M-E-T-M] (39). As depicted in Figure 6, peptide overlays show that the carbon backbone configuration for horse cyt $c$ p41-49 and the analogue peptides bound to $\mathrm{H}-2 \mathrm{~K}^{\mathrm{b}}$ (Figure 6A and $\mathrm{C}$ ) are comparable with the exception of the carboxyl terminus. A distal carbon backbone shift is seen for the carboxyl terminal anchor residue, $\mathrm{Thr}^{49}$, for both $\mathrm{p} 41-49 / 44 \mathrm{~A}$ and $\mathrm{p} 41-49 / 45 \mathrm{~A}$. Concomitantly, the side chain of $\mathrm{Thr}^{49}$ was rotated in the D pocket for both analogue $\mathrm{p} 41$ 49/44A and analogue p41-49/45A. Individual residue side chain orientations were also affected by the Ala substitutions at $\mathrm{p} 4$ or p5. As these peptide overlays clearly showed, residues $\mathrm{Glu}^{42}, \mathrm{Phe}^{46}, \mathrm{Thr}^{47}$ and $\mathrm{Tyr}^{48}$ in both the $\mathrm{p} 41-49 / 44 \mathrm{~A}$ and $\mathrm{p} 41-49 / 45 \mathrm{~A}$ analogue underwent conformational changes affecting R-group orientation. The most striking residue side chain modification influencing available TCR-peptide contact, with the exception of the P44A substitution, involves $\mathrm{Phe}^{46}$ found at peptide position p6. The aromatic ring of $\mathrm{Phe}^{46}$ is rotated approximately $60^{\circ}$ for both $\mathrm{p} 41-49 / 44 \mathrm{~A}$ and $\mathrm{p} 41-49 / 45 \mathrm{~A}$ 
compared to native horse cyt $c$ p41-49. As noted previously (Frankenberry et al, manuscript submitted), this residue constitutes the largest proportion of the surfaceaccessible area available for contact by the Clone B6.H-4.1c TCR when engaged with native horse cyt $c$ p $41-49$.

The carbon backbone configurations of horse cyt $c$ p41-49 and the analogue peptides bound to $\mathrm{H}-2 \mathrm{D}^{\mathrm{b}}$ are comparable, with the exception of a distal shift of $\mathrm{Ala}^{43}$ in both $\mathrm{p} 41-49 / 44 \mathrm{~A}$ and $\mathrm{p} 41-49 / 45 \mathrm{~A}$ (Figure 6B and D). The shift in the carbon backbone primarily affects the orientation of the imino ring of $\mathrm{Pro}^{44}$ found in $\mathrm{p} 41-49 / 45 \mathrm{~A}$, and contributes to modest residue side chain modifications at $\mathrm{Phe}^{46}, \mathrm{Thr}^{47}$ and $\mathrm{Tyr}^{48}$ in both peptide analogues. Unlike the dramatic rotation of the aromatic ring of $\mathrm{Phe}^{46}$ for both cyt $c$ p 41-49 analogues when bound to $\mathrm{H}-2 \mathrm{~K}^{\mathrm{b}}$, there was a minor, but clearly distinguishable, change in the orientation of this aromatic ring when these peptides are bound to $H-2 D^{b}$. Computer-generated molecular models (Figure 6B and D) indicated that the distal shift of the imino ring of $\mathrm{Pro}^{44}$ at peptide position $\mathrm{p} 4$ and the change in orientation of the aromatic ring of Phe ${ }^{46}$ resulted in decreased surface-accessibility of TCR-peptide contact residues. Thus, changes in peptide-specific sites of TCR engagement accounted for the differences in Clone B6.H-4.1c responsiveness for $\mathrm{H}-2 \mathrm{D}^{\mathrm{b}} / \mathrm{cyt} c \mathrm{p} 41-49$ and $\mathrm{H}-2 \mathrm{D}^{\mathrm{b}} / \mathrm{p} 41$ 49/45A complexes. 


\section{DISCUSSION}

In this paper we addressed the potential role of a type II $\beta$ bend, attributed to the presence of a $\mathrm{Pro}^{44}$ Gly $^{45}$ dipeptide, in determining the dual-reactive response of CTL Clone B6.H-4.1c to $\mathrm{H}-2 \mathrm{~K}^{\mathrm{b}} / \mathrm{cyt} \quad c \mathrm{p} 41-49$ and $\mathrm{H}-2 \mathrm{D}^{\mathrm{b}} / \mathrm{cyt} c \mathrm{p} 41-49$ complexes. We previously demonstrated that the $\mathrm{CD}^{+} \mathrm{CTL}$ Clone B6.H-4.1c was specific for the horse cyt $c$-derived peptide, cyt $c$ p41-49, presented in the context of $H-2 K^{b}, H-2 D^{b}$ as well as the mutant molecule, $\mathrm{H}-2 \mathrm{~K}^{\mathrm{bm} 1}(9)$. Recently, our observations revealed that the horse cyt $c$ p41-49 dipeptide sequence, Pro $^{44}-\mathrm{Gly}^{45}$, formed a type II $\beta$ bend that facilitated binding to both $\mathrm{H}-2 \mathrm{~K}^{\mathrm{b}}$ and $\mathrm{H}-2 \mathrm{D}^{\mathrm{b}}$ molecules. Ploegh and coworkers $(27,28)$ predicted that nonameric peptides have the capacity to bind to $\mathrm{H}-2 \mathrm{~K}^{\mathrm{b}}$ molecules if the peptide sequence contains Pro-Gly residues in tandem. They showed that the presence of a Pro-Gly dipeptide sequence causes a configurational restraint that facilitates binding of SEV-9 to $\mathrm{H}-2 \mathrm{~K}^{\mathrm{b}}$ at concentrations comparable to that for the known $\mathrm{H}-2 \mathrm{~K}^{\mathrm{b}}$-restricted octamers, VSV-8 and OVA $257-264(27)$.

The presence of a Pro-Gly dipeptide sequence is also important for the maintenance of the type II $\beta$ bend of peptides derived from HIV-1 envelope glycoprotein gp120 (41). In this study, the presence of secondary structure elements found in immunogenic peptides of 12,24 and 40 residues in length were analyzed by nuclear magnetic resonance (NMR). Although the majority of peptide residues lack a defined folded structure, the regions containing the conserved Pro-Gly sequence indicated a type II $\beta$ bend (41). Analysis of site-directed mutations in the hen lysozyme gene illustrated the importance of Pro-Gly sequences in maintaining the global structure and function of 
intact proteins (42). Disruption of the Pro-Gly induced $\beta$-sheet resulted in minor structural changes but contributed to a significant decrease in the activity of the lysozyme molecule (42). Likewise, site-directed mutagenesis of the yeast iso-1-cyt $c$ type II $\beta$ bend, contributed by the conserved $\mathrm{Pro}^{76}-\mathrm{Gly}^{77}$ sequence, resulted in a significant decrease in protein function (43).

We (9 and Frankenberry et al, manuscript submitted) recently proposed that the Pro $^{44}-\mathrm{Gly}^{45}$ sequence in horse cyt $c$ p $41-49$ forms a type II $\beta$ bend that not only facilitates binding to $\mathrm{H}-2 \mathrm{~K}^{\mathrm{b}}$ and $\mathrm{H}-2 \mathrm{D}^{\mathrm{b}}$, but also causes the peptide to protrude out of the antigenbinding cleft, thus providing essential contacts for the Clone B6.H-4.1c TCR. Computergenerated molecular models of these $\mathrm{MHC} /$ peptide complexes suggest that $\mathrm{Pro}^{44}$ and $\mathrm{Phe}^{46}$ at peptide positions $\mathrm{p} 4$ and $\mathrm{p} 6$ represented the major solvent-exposed residues available for TCR engagement when horse cyt $c$ p41-49 was presented in the context of $\mathrm{H}-2 \mathrm{~K}^{\mathrm{b}}$ and $\mathrm{H}-2 \mathrm{D}^{\mathrm{b}}$. Due to the close similarity in the orientation and extent of surfaceaccessibility, we hypothesized that the $\mathrm{H}-2 \mathrm{~K}^{\mathrm{b}}$ - and $\mathrm{H}-2 \mathrm{D}^{\mathrm{b}}$-restricted recognition of horse cyt $c$ p41-49 by Clone B6.H-4.1c is dependent upon the solvent-exposed imino group of Pro $^{44}$ at peptide position $\mathrm{p} 4$. We obtained horse cyt $c$ p41-49 analogues consisting of a single Ala substitution, (P44A) and (G45A), at peptide positions $\mathrm{p} 4$ and $\mathrm{p} 5$, respectively and evaluated the effect of disrupting the type II $\beta$ bend on $H-2 K^{b}$ - and $H-2 D^{b}$-binding and Clone B6.H-4.1c recognition.

We first determined the cytolytic response of Clone B6.H-4.1c to analogues $\mathrm{p} 41-49 / 44 \mathrm{~A}$ and $\mathrm{p} 41-49 / 45 \mathrm{~A}$, at a constant $2 \mu \mathrm{M}$ concentration, by performing standard 4-h ${ }^{51} \mathrm{Cr}$-release assays (Figure 1). Clone B6.H-4.1c CTL effectors recognize analogue p41-49/45A but not $\mathrm{p} 41-49 / 44 \mathrm{~A}$ when presented by $\mathrm{H}-2 \mathrm{~K}^{\mathrm{b}}$ - and $\mathrm{H}-2 \mathrm{D}^{\mathrm{b}}$-expressing target 
cells. This suggests that either analogue p41-49/44A fails to bind to and stabilize the class I H-2 ${ }^{\mathrm{b}}$ molecules, or that the P44A substitution induces MHC/peptide conformation changes that inhibit Clone B6.H-4.1c recognition.

Based on the peptide-binding motifs described by Rammensee and coworkers for $\mathrm{H}-2 \mathrm{~K}^{\mathrm{b}}(40)$, both horse cyt $c$ p41-49 analogues contain a single dominant anchor and a weak anchor for binding to $\mathrm{H}-2 \mathrm{~K}^{\mathrm{b}}$ (Table I). The $\mathrm{p} 41-49 / 45 \mathrm{~A}$ analogue also contains the weak anchor Pro ${ }^{44}$ at peptide position $\mathrm{p} 4$. Both $\mathrm{p} 41-49 / 44 \mathrm{~A}$ and $\mathrm{p} 41-49 / 45 \mathrm{~A}$ contain a single strong anchor and three weak anchor residues described for binding to $H-2 \mathrm{D}^{\mathrm{b}}(40)$ (Table II). The absence of the weak anchor, Pro ${ }^{44}$, in $\mathrm{p} 41-49 / 44 \mathrm{~A}$ may influence $\mathrm{H}-2 \mathrm{~K}^{\mathrm{b}}$, but not $\mathrm{H}-2 \mathrm{D}^{\mathrm{b}}$, binding and presentation. Alternatively the $\mathrm{P} 44 \mathrm{~A}$ substitution could disrupt the type II $\beta$ bend such that p41-49/44A no longer forms MHC-peptide interactions necessary for stable expression of these $\mathrm{H}-2^{\mathrm{b}}$ molecules.

We performed RMA-S stabilization assays to address the possibility that p41-49/44A fails to form stable MHC/peptide complexes directly. These results show (Figure 2) that both $\mathrm{p} 41-49 / 44 \mathrm{~A}$ and $\mathrm{p} 41-49 / 45 \mathrm{~A}$ are bound to and stabilize $\mathrm{H}-2 \mathrm{~K}^{\mathrm{b}}$ and H-2D ${ }^{b}$ molecules. Native horse cyt $c$ p41-49 and p41-49/44A exhibit similar rates of dissociation from both class I MHC molecules. These results also reveal efficient binding of $\mathrm{p} 41-49 / 45 \mathrm{~A}$ to $\mathrm{H}-2 \mathrm{~K}^{\mathrm{b}}$ and enhanced $\mathrm{MHC} /$ peptide complex stability. In additionally, we show that although analogue p41-49/45A is presented in the context of $\mathrm{H}-2 \mathrm{D}^{\mathrm{b}}$, it exhibits a rapid rate of dissociation.

To determine the cytolytic activity of Clone B6.H-4.1c for $\mathrm{H}-2 \mathrm{~K}^{\mathrm{b}}$ and $\mathrm{H}-2 \mathrm{D}^{\mathrm{b}}$ complexed with native horse cyt c p41-49 or p41-49/45A, peptide titration studies (Figure 3 and Table III) were performed. A minimal peptide concentration of $\sim 4 \mathrm{nM}$ and 
$\sim 2 \mathrm{nM}$ is required for Clone B6.H-4.1c recognition of native horse cyt $c \mathrm{p} 41-49$ presented by $\mathrm{H}-2 \mathrm{~K}^{\mathrm{b}}$ and $\mathrm{H}-2 \mathrm{D}^{\mathrm{b}}$, respectively. Conversely, the Clone B6.H-4.1c lytic response to p41-49/45A associated with $\mathrm{H}-2 \mathrm{~K}^{\mathrm{b}}$ and $\mathrm{H}-2 \mathrm{D}^{\mathrm{b}}$ requires significantly higher concentrations, $>30$-fold and $>30$-fold respectively. We also performed peptide competition studies, using $\mathrm{p} 41-49 / 44 \mathrm{~A}$ and MI B chain $\mathrm{p} 7-15$ as competitor peptides, to evaluate the efficiency of Clone B6.H-4.1c recognition for $\mathrm{H}-2 \mathrm{~K}^{\mathrm{b}}$ and $\mathrm{H}-2 \mathrm{D}^{\mathrm{b}}$ molecules associated with native horse cyt $c$ p41-49 or p41-49/45A. The introduction of either competitor peptide significantly increases the target peptide (native horse cyt $c$ p41-49 or p41-49/45A) concentration required for optimal target cell lysis (Figures 4 and 5; Table III). The non-horse cyt $c$ related peptide, MI B chain $\mathrm{p} 7-15$, acts as the best peptide competitor, requiring higher concentrations of both target peptides for Clone B6.H-4.1c recognition of $\mathrm{H}-2^{\mathrm{b}} /$ peptide complexes. It may well be that the $\mathrm{Gly}^{8}-\mathrm{Pro}^{9}$ sequence located within MI B chain p7-15 mimics, at least in part, the $\mathrm{H}-2 \mathrm{~K} / \mathrm{p} 41-49$ and $\mathrm{H}-2 \mathrm{D}^{\mathrm{b}} / \mathrm{p} 41-49$ complexes.

Clearly, these findings show that the Clone B6.H-4.1c TCR is able to distinguish minute changes in the MHC/peptide conformation caused by the G45A substitution, as well as the P44A substitution. These findings are in agreement with several reports which indicates that a single amino acid substitution in the target peptide primary sequence can cause alterations in MHC/peptide conformation, without affecting the number of complexes available to the TCR, and consequently interfere with $\mathrm{T}$ cell recognition (44-47).

Combinatorial peptide libraries were utilized by Joyce and coworkers (26) to show that two unique CTL clones require only one of four putative TCR contact residues 
for target cell recognition. We previously demonstrated that $\mathrm{Pro}^{44}$ and $\mathrm{Phe}^{46}$ at peptide positions $\mathrm{p} 4$ and $\mathrm{p} 6$ represent the major solvent-exposed residues available for TCR contact when horse cyt $c$ p41-49 is presented in the context of $\mathrm{H}-2 \mathrm{~K}^{\mathrm{b}}$ and $\mathrm{H}-2 \mathrm{D}^{\mathrm{b}}$ (Frankenberry et al, manuscript submitted). Peptide overlays (Figures 6A and 6C) of native horse cyt c p41-49 and both peptide analogues show a distal carbon backbone shift at $\mathrm{Thr}^{49}$ in the carboxyl terminus for $\mathrm{p} 41-49 / 44 \mathrm{~A}$ and $\mathrm{p} 41-49 / 45 \mathrm{~A}$. The aromatic ring of $\mathrm{Phe}^{46}$ is rotated approximately $60^{\circ}$ for both analogues bound to $\mathrm{H}-2 \mathrm{~K}^{\mathrm{b}}$, and a minor shift occurs in their carbon backbones at $\mathrm{Ala}^{43}$ when bound to $\mathrm{H}-2 \mathrm{D}^{\mathrm{b}}$ (Figure $6 \mathrm{~B}$ and $\mathrm{D}$ ). Unlike the observations for $\mathrm{p} 41-49 / 44 \mathrm{~A}$ and $\mathrm{p} 41-49 / 45 \mathrm{~A}$ bound to $\mathrm{H}-2 \mathrm{~K}^{\mathrm{b}}$, there is a small but distinguishable change in the orientation of the aromatic ring of $\mathrm{Phe}^{46}$ when they bind to $\mathrm{H}-2 \mathrm{D}^{\mathrm{b}}$. In addition the imino group of $\mathrm{Pro}^{44}$, absent in analogue p41-49/44A, remains relatively unaltered for analogue $\mathrm{p} 41-49 / 45 \mathrm{~A}$ bound to $\mathrm{H}-2 \mathrm{~K}^{\mathrm{b}}$ or $\mathrm{H}-2 \mathrm{D}^{\mathrm{b}}$. Thus, the lack of responsiveness of Clone B6.H-4.1c to both $\mathrm{H}-2 \mathrm{~K}^{\mathrm{b}} / \mathrm{p} 41-49 / 44 \mathrm{~A}$ and $\mathrm{H}-2 \mathrm{D}^{\mathrm{b}} / \mathrm{p} 41-49 / 44 \mathrm{~A}$ complexes is likely due to the loss of $\operatorname{Pro}^{44}$ at peptide position p4. Also the shift of the aromatic ring of $\mathrm{Phe}^{46}$ directly affects the cytolytic response of Clone B6.H-4.1c for $\mathrm{H}-2 \mathrm{~K}^{\mathrm{b}} / \mathrm{cyt} c \mathrm{p} 41-49$ and $\mathrm{H}-2 \mathrm{~K}^{\mathrm{b}} / \mathrm{p} 41-49 / 45 \mathrm{~A}$ complexes (Figures $3-5$ and Table III). Furthermore, the partial response of Clone B6.H-4.1c for p41-49/45A bound to $\mathrm{H}-2 \mathrm{~K}^{\mathrm{b}}$ appears to be largely due to a change in orientation of the aromatic ring of $\mathrm{Phe}^{46}$ at peptide position p6. Although computer-generated molecular models suggest that few alterations exist in the overall configuration of $\mathrm{p} 41-49 / 45 \mathrm{~A}$ bound to $\mathrm{H}-2 \mathrm{D}^{\mathrm{b}}$, the RMA-S stabilization experiments clearly show that this peptide dissociates rapidly from the $\mathrm{H}-2 \mathrm{D}^{\mathrm{b}}$ molecule. This rapid dissociation of $\mathrm{p} 41-49 / 45 \mathrm{~A}$ from $\mathrm{H}-2 \mathrm{D}^{\mathrm{b}}$ corresponds more 
closely to the decreased responsiveness of Clone B6.H-4.1c than overt changes in peptide configuration.

Several investigators have described CTL clones that respond to a single peptide presented in the context of more than one MHC molecule (6-12). Various explanations have been proposed to account for the observed degenerate $\mathrm{T}$ cell restriction demonstrated by these CTL clones. One consideration is that TCR interactions may be dependent on specific peptide configurations located in the central solvent-exposed portions of the MHC/peptide complex. Thus, degenerate $\mathrm{T}$ cell restriction may involve some cross-reactivity for common peptide configurations shared by multiple MHC/peptide complexes. This is reinforced by studies showing that a single MHC molecule can present up to $10^{4}$ different peptides on the cell surface and proteasomes and TAP transporters are highly selective for the peptides they convey into the ER (48-50).

The results described in this paper support for this model; in that a P44A substitution in horse cyt $c$ p $41-49$ abrogates recognition of both $\mathrm{H}-2 \mathrm{~K} / \mathrm{p} 41-49 / 44 \mathrm{~A}$ and H-2D $/ p 41-49 / 44 A$ complexes. Although removal of the centrally located, solventexposed Pro ${ }^{44}$ residue at peptide position 44 does not adversely affect binding to either $\mathrm{H}-2 \mathrm{~K}^{\mathrm{b}}$ or $\mathrm{H}-2 \mathrm{D}^{\mathrm{b}}$, it disrupts interactions with the TCR of Clone B6.H-4.1c that are essential for recognition. The G45A substitution also contributes directly to decreased recognition of Clone B6.H-4.1c for $\mathrm{H}-2 \mathrm{~K} / \mathrm{p} 41-49 / 45 \mathrm{~A}$ complexes by altering the orientation of available TCR contact residues, thus reducing Clone B6.H-4.1c TCR interactions despite the presence of the imino group contributed by $\operatorname{Pro}^{44}$. The G45A substitution may also indirectly contribute to the decreased CTL response to $\mathrm{H}-2 \mathrm{D}^{\mathrm{b}} / \mathrm{p} 41$ 49/45A complexes by inducing configurational constraints that promote the rapid 
dissociation of this peptide from $\mathrm{H}-2 \mathrm{D}^{\mathrm{b}}$. Overall, the findings in this paper suggest that the solvent-exposed $\mathrm{R}$ groups of both $\mathrm{Pro}^{44}$ and $\mathrm{Phe}^{46}$ are critically important for Clone B6.H-4.1c recognition of $\mathrm{H}-2 \mathrm{~K}^{\mathrm{b}} / \mathrm{cyt} c \mathrm{p} 41-49$ and $\mathrm{H}-2 \mathrm{D}^{\mathrm{b}} / \mathrm{cyt} c \mathrm{p} 41-49$ complexes. The presence of the imino group contributed by $\operatorname{Pro}^{44}$ is necessary for recognition by Clone B6.H-4.1c and the $\mathrm{Gly}^{45}$ residue is responsible for the proper orientation of the aromatic ring of $\mathrm{Phe}^{46}$ that is essential for full Clone B6.H-4.1c responsiveness. 


\section{Table I}

The $\mathrm{K}^{\mathrm{b}}$-restricted peptide-binding motif for native horse cyt $c$ p41-49, analogue p41-49/44A, analogue $p 41-49 / 45 A$ and $M I B$ chain $p 7-15^{a}$.

\begin{tabular}{lllllllll}
1 & 2 & 3 & 4 & 5 & 6 & 7 & 8 & 9 \\
\hline
\end{tabular}

Dominant anchor residues

$\begin{array}{ll}\mathbf{F} & \mathbf{L} \\ \mathrm{Y} & \end{array}$

Strong anchor residues

Y

Weak anchor residues

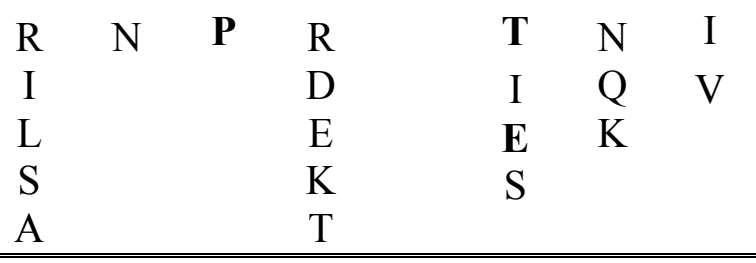

$\begin{array}{lllllllllll}\text { Native horse cyt } c \text { p41-49 } & \text { G } & \text { Q } & \text { A } & \text { P } & \text { G } & \text { F } & \text { T } & \text { Y } & \text { T }\end{array}$

Analogue p41-49/44A

$\begin{array}{llllllllll}\text { G } & \text { Q } & \text { A } & \text { A } & \text { G } & \text { F } & \text { T } & \text { Y } & \text { T }\end{array}$

Analogue p41-49/45A

$\begin{array}{lllllllll}\text { G } & \text { Q } & \text { A } & \text { P } & \text { A } & \text { F } & \text { T } & \text { Y } & \text { T }\end{array}$

MI B chain p7-15

$\begin{array}{llllllllll}\text { C } & \text { G } & \text { P } & \text { H } & \text { L } & \text { V } & \text { E } & \text { A } & \text { L }\end{array}$

${ }^{a}$ Anchor residues contributing to peptide binding and presentation are shown in bold type. 
Table II

The $D^{b}$-restricted peptide-binding motif for native horse cyt $c$ p41-49, analogue p41-49/44A, analogue $p 41-49 / 45 A$ and $M I B$ chain $p 7-15^{a}$.

\begin{tabular}{|c|c|c|c|c|c|c|c|c|c|}
\hline & 1 & 2 & 3 & 4 & 5 & 6 & 7 & 8 & 9 \\
\hline Dominant anchor residues & & & & & $\mathrm{N}$ & & & & M \\
\hline \multirow[t]{4}{*}{ Strong anchor residues } & & $\mathbf{M}$ & $\mathrm{I}$ & $\mathrm{K}$ & & $\mathrm{L}$ & & & \\
\hline & & & $\mathrm{L}$ & $\mathrm{E}$ & & $\mathbf{F}$ & & & \\
\hline & & & $\mathbf{P}$ & Q & & & & & \\
\hline & & & $\mathrm{V}$ & $\mathrm{V}$ & & & & & \\
\hline \multirow[t]{12}{*}{ Weak anchor residues } & $\mathrm{A}$ & A & $\mathrm{G}$ & $\mathrm{D}$ & & A & $\mathrm{D}$ & $\mathrm{F}$ & $\mathbf{L}$ \\
\hline & $\mathrm{N}$ & $\mathbf{Q}$ & & $\mathrm{T}$ & & $\mathrm{Y}$ & $\mathbf{E}$ & $\mathrm{H}$ & \\
\hline & $\mathrm{I}$ & $\mathrm{D}$ & & & & $\mathrm{T}$ & Q & $\mathrm{K}$ & \\
\hline & $\mathrm{F}$ & & & & & $\mathbf{V}$ & V & $\mathrm{S}$ & \\
\hline & $\mathrm{P}$ & & & & & M & $\mathbf{T}$ & $\mathbf{Y}$ & \\
\hline & $\mathrm{S}$ & & & & & $\mathrm{E}$ & $\mathrm{Y}$ & & \\
\hline & $\mathrm{T}$ & & & & & Q & & & \\
\hline & $\mathrm{V}$ & & & & & $\mathrm{H}$ & & & \\
\hline & & & & & & $\mathrm{I}$ & & & \\
\hline & & & & & & $\mathrm{K}$ & & & \\
\hline & & & & & & $\mathrm{P}$ & & & \\
\hline & & & & & & $\mathrm{S}$ & & & \\
\hline Native horse cyt $c$ p41-49 & G & $\mathbf{Q}$ & A & $\mathrm{P}$ & G & $\mathbf{F}$ & $\mathbf{T}$ & $\mathbf{Y}$ & $\mathrm{T}$ \\
\hline Analogue p41-49/44A & G & $\mathbf{Q}$ & A & A & G & $\mathbf{F}$ & $\mathbf{T}$ & $\mathbf{Y}$ & $\mathrm{T}$ \\
\hline Analogue p41-49/45A & G & $\mathbf{Q}$ & A & $\mathrm{P}$ & A & $\mathbf{F}$ & $\mathbf{T}$ & $\mathbf{Y}$ & $\mathrm{T}$ \\
\hline MI B chain p7-15 & $\mathrm{C}$ & $\mathrm{G}$ & $\mathbf{P}$ & $\mathrm{H}$ & $\mathrm{L}$ & $\mathbf{V}$ & $\mathbf{E}$ & $\mathrm{A}$ & $\mathbf{L}$ \\
\hline
\end{tabular}

${ }^{a}$ Anchor residues contributing to peptide binding and presentation are shown in bold type. 
Table III

Peptide competition assays reveal that significantly higher concentrations of native cyt $c$ p41-49 and the p41-49/45A analogue are required for Clone B6.H-4.1c recognition.

\begin{tabular}{|c|c|c|c|c|c|}
\hline Class I MHC & $\begin{array}{l}\text { Target } \\
\text { peptide }\end{array}$ & $\begin{array}{l}\text { Optimal target } \\
\text { peptide } \\
\text { concentration }\end{array}$ & $\begin{array}{l}\text { Competitor } \\
\text { peptide }\end{array}$ & $\begin{array}{l}\text { Optimal target } \\
\text { peptide } \\
\text { concentration } \\
\text { in the presence } \\
\text { of competitor } \\
\text { peptide }\end{array}$ & $\begin{array}{c}\text { Statistical } \\
\text { significance } \\
(\mathrm{p} \text { value })^{2}\end{array}$ \\
\hline $\mathrm{H}-2 \mathrm{~K}^{\mathrm{b}}$ & $\begin{array}{c}\text { Native cyt } c \\
\text { p41-49 }\end{array}$ & $\sim 4 \mathrm{nM}^{3}$ & $\begin{array}{c}\text { MI } \\
\text { p7-15 }\end{array}$ & $\sim 150 \mathrm{nM}^{3}$ & $\mathrm{p}<0.05$ \\
\hline $\mathrm{H}-2 \mathrm{~K}^{\mathrm{b}}$ & $\begin{array}{c}\text { Native cyt } c \\
\text { p41-49 }\end{array}$ & $\sim 4 \mathrm{nM}$ & $\begin{array}{c}\text { Analogue } \\
\text { p41-49/44A }\end{array}$ & $\sim 25 \mathrm{nM}$ & $\mathrm{p}<0.001$ \\
\hline $\mathrm{H}-2 \mathrm{D}^{\mathrm{b}}$ & $\begin{array}{c}\text { Native cyt } c \\
\text { p41-49 }\end{array}$ & $\sim 2 \mathrm{nM}$ & $\begin{array}{c}\text { MI } \\
\text { p7-15 }\end{array}$ & $\sim 230 \mathrm{nM}$ & $\mathrm{p}<0.05$ \\
\hline$H-2 D^{b}$ & $\begin{array}{c}\text { Native cyt } c \\
\mathrm{p} 41-49 \\
\end{array}$ & $\sim 2 \mathrm{nM}$ & $\begin{array}{c}\text { Analogue } \\
\text { p41-49/44A }\end{array}$ & $\sim 25 \mathrm{nM}$ & $\mathrm{p}<0.05$ \\
\hline $\mathrm{H}-2 \mathrm{~K}^{\mathrm{b}}$ & $\begin{array}{c}\text { Analogue } \\
\text { p41-49/45A }\end{array}$ & $\sim 125 \mathrm{nM}$ & $\begin{array}{c}\mathrm{MI} \\
\mathrm{p} 7-15\end{array}$ & $\sim 950 \mathrm{nM}$ & $\mathrm{p}<0.05$ \\
\hline $\mathrm{H}-2 \mathrm{~K}^{\mathrm{b}}$ & $\begin{array}{c}\text { Analogue } \\
\text { p41-49/45A }\end{array}$ & $\sim 125 \mathrm{nM}$ & $\begin{array}{c}\text { Analogue } \\
\text { p41-49/44A }\end{array}$ & $\sim 250 \mathrm{nM}$ & $\mathrm{p}=0.08$ \\
\hline $\mathrm{H}-2 \mathrm{D}^{\mathrm{b}}$ & $\begin{array}{c}\text { Analogue } \\
\text { p41-49/45A }\end{array}$ & $\sim 80 \mathrm{nM}$ & $\begin{array}{c}\text { MI } \\
\text { p7-15 }\end{array}$ & $\sim 1400 \mathrm{nM}$ & $\mathrm{p}<0.05$ \\
\hline$H-2 D^{b}$ & $\begin{array}{c}\text { Analogue } \\
\text { p41-49/45A }\end{array}$ & $\sim 80 \mathrm{nM}$ & $\begin{array}{c}\text { Analogue } \\
\text { p41-49/44A }\end{array}$ & $\sim 250 \mathrm{nM}$ & $\mathrm{p}<0.05$ \\
\hline
\end{tabular}

${ }^{1}$ Optimal peptide concentrations determined as the peptide concentration required to yield 30\% lysis by Clone B6H-4.1c.

2 Statistical significance determined by Student's $t$-test as described in the Materials and Methods.

${ }^{3}$ Peptide concentrations are given as the mean of five separate experiments for optimal peptide concentrations and three separate experiments for peptide competition assays, with an effector-to-target ratio of 3:1. 


\section{FIGURES AND FIGURE LEGENDS}

Fig. 1 Clone B6.H-4.1c recognizes the horse cyt $c$ analogue, p41-49/45A, but not analogue p41-49/44A.

$\mathrm{L}+\mathrm{K}^{\mathrm{b}}, \mathrm{L}+\mathrm{D}^{\mathrm{b}}$ and $\mathrm{LMTK}^{-51} \mathrm{Cr}$-labeled target cells were incubated for $20 \mathrm{~min}$ in the presence or absence $(\mathrm{O})$ of $2 \mu \mathrm{M}$ concentrations of target peptide, horse cyt $c$ p41-49 (•), analogue p41-49/44A ( $\boldsymbol{\square})$ or analogue p41-49/45A ( $\boldsymbol{\Delta})$. After peptide incubation, the CTL Clone B6.H-4.1c was added at an effector-to-target ratio of 30:1, 10:1, 3:1 and 1:1 and supernatants were collected $4 \mathrm{~h}$ later. Supernatants $(100 \mu \mathrm{l})$ were collected and cytolytic activity was represented by the "percent specific lysis". Spontaneous release of targets in the absence of CTL effectors was $<10 \%$ of maximum lysis by detergent in all experiments. A single representative of four separate experiments is shown. 


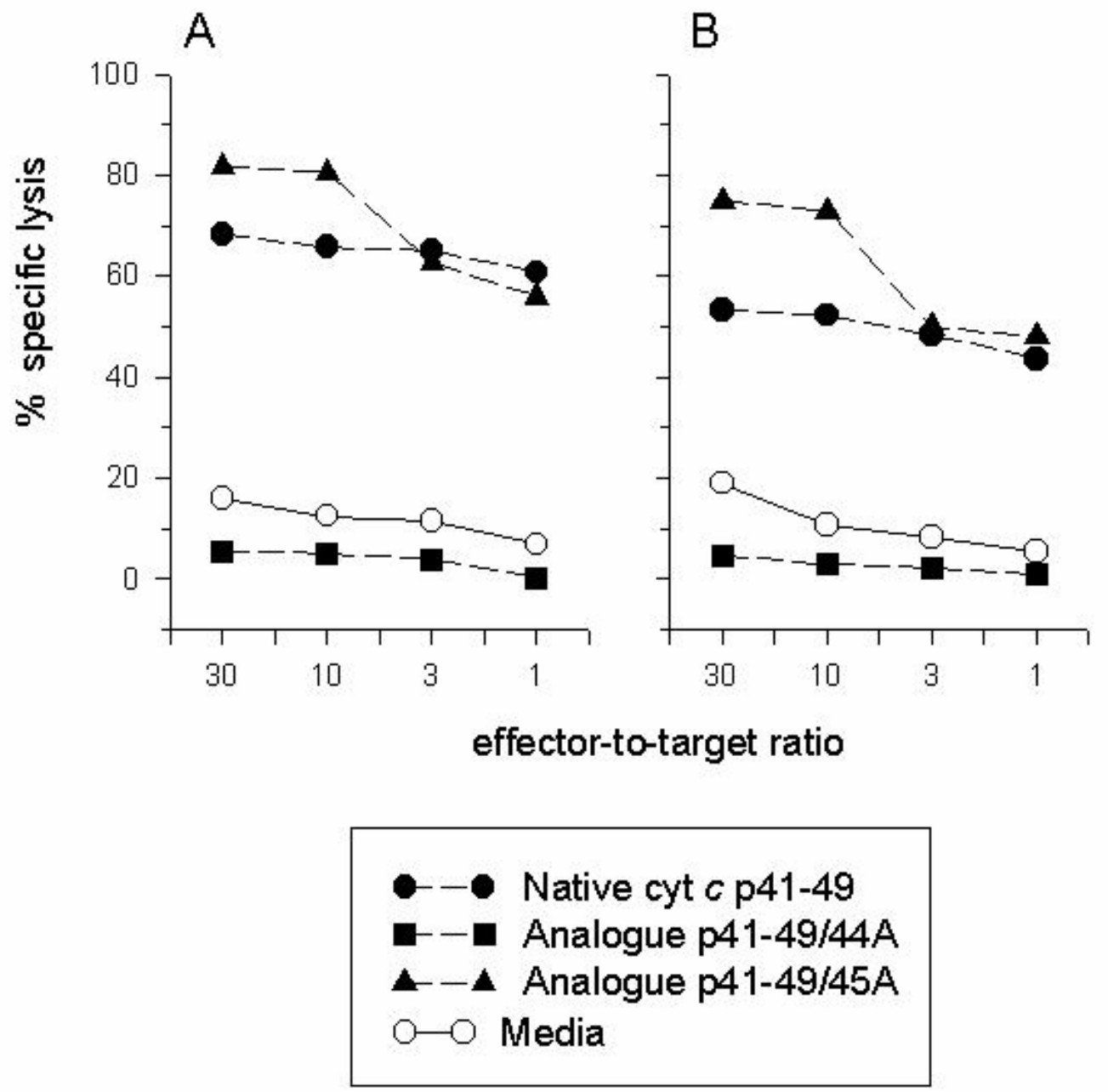


Fig. 2 Native horse cyt $c$ p41-49 and the analogues, p41-49/44A and p41-49/45A, stabilize $H-2 K^{b}$ and $H-2 D^{b}$ molecules.

$2.5 \times 10^{6}$ RMA-S cells were pulsed with $10 \mu \mathrm{M}$ concentrations of horse cyt $c$ p41-49

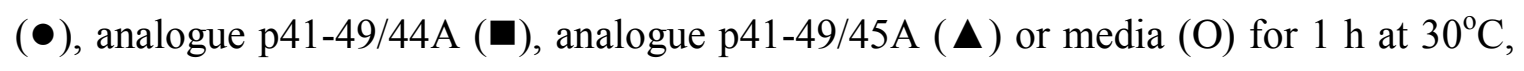
$5 \% \mathrm{CO}_{2}$. Cells were then washed to remove excess unbound peptide and incubated for 0 , $30,60,120$ and $180 \mathrm{~min}$ at $37^{\circ} \mathrm{C}, 7 \% \mathrm{CO}_{2}$. At each time point, $5 \times 10^{5}$ cells were removed and stained for the presence of stable surface $H-2 K^{b}(A)$ and $H-2 D^{b}(B)$ molecules. Mean channel fluorescence was determined by flow cytometric analysis and was represented as the fluorescence index as described in Materials and Methods. A single representative of three separate experiments is shown. 


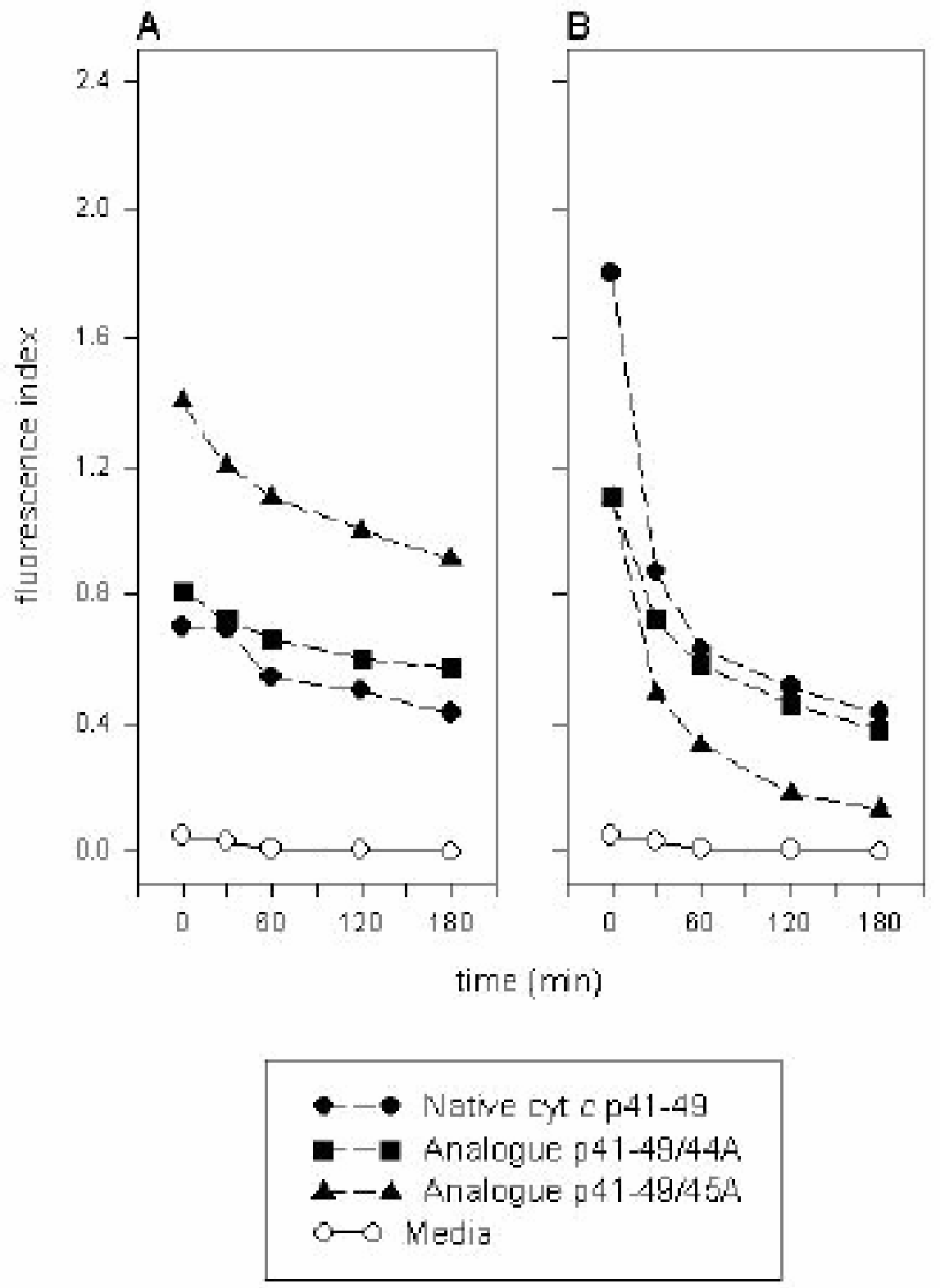


Fig. 3 Significantly higher analogue p41-49/45A peptide concentrations ${ }^{1}$ are required for optimal target cell lysis by Clone B6.H-4.1c.

$\mathrm{L}+\mathrm{K}^{\mathrm{b}}(\mathrm{A}), \mathrm{L}+\mathrm{D}^{\mathrm{b}}(\mathrm{B})$ and $\mathrm{LMTK}^{-}(\mathrm{O})$ cells were incubated for $20 \mathrm{~min}$ in the presence of varying concentrations $(2 \mathrm{pM}$ to $2 \mu \mathrm{M})$ of target peptide, horse cyt $c$ p41-49 (•), analogue p41-49/44A ( $\mathbf{\square})$ or analogue p41-49/45A ( $\mathbf{\Delta})$. After peptide incubation, Clone B6.H-4.1c was added at an effector-to-target ratio of $3: 1$ for $4 \mathrm{~h}$. Supernatants $(100 \mu \mathrm{l})$ were collected and cytolytic activity was represented by the "percent specific lysis". Spontaneous release of targets in the absence of CTL effectors was $<10 \%$ of maximum lysis by detergent in all experiments. A single representative of five separate experiments is shown.

${ }^{1}$ Minimal peptide concentrations were determined as the peptide concentration required to yield 30\% lysis by Clone B6.H-4.1c. 

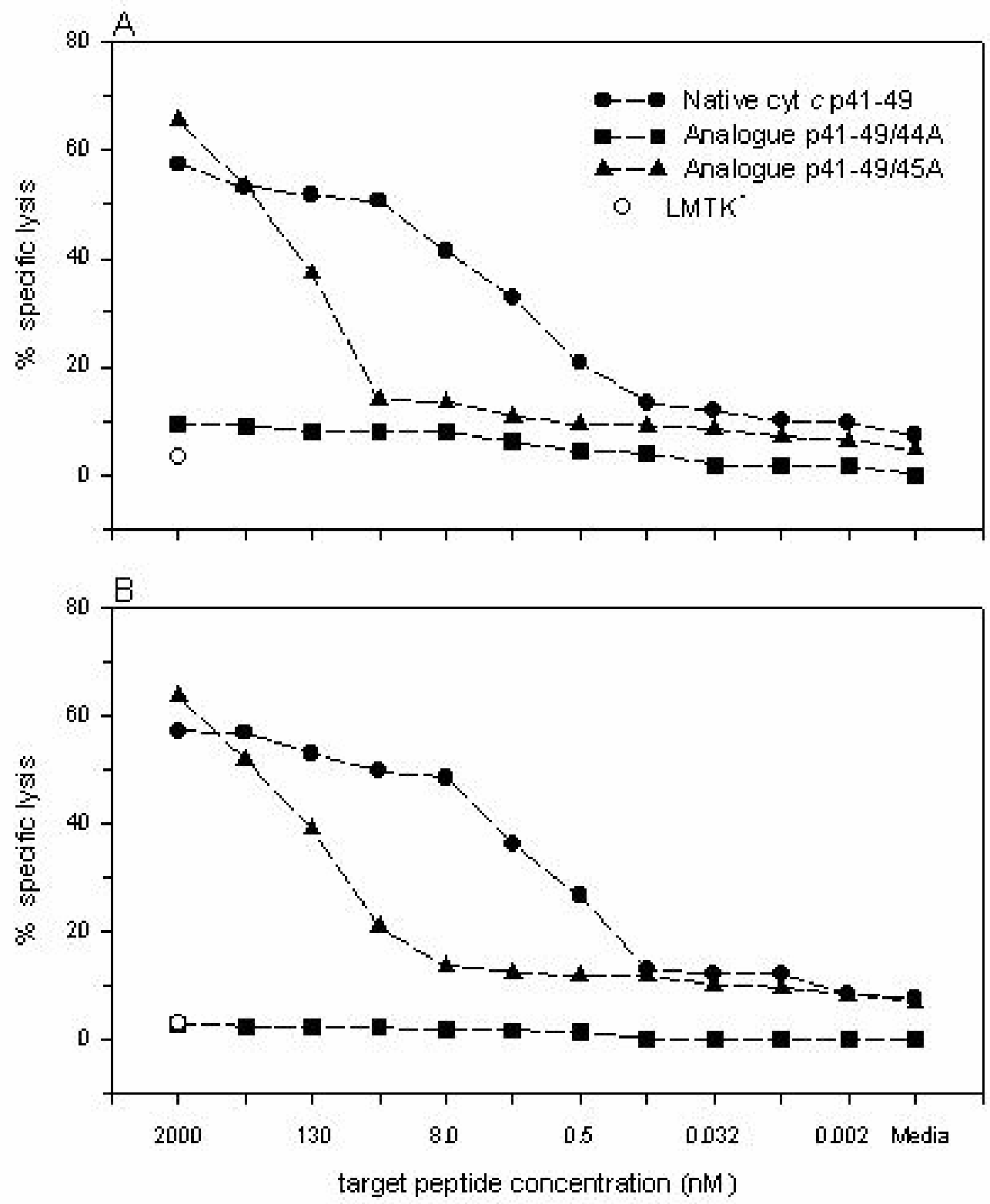
Fig. 4 Clone B6.H-4.1c responsiveness to horse cyt $c$ p41-49 is inhibited by the competitor peptides, MI B chain p7-15 and analogue p41-49/44A.

$\mathrm{L}+\mathrm{K}^{\mathrm{b}}(\mathrm{A})$ and $\mathrm{L}+\mathrm{D}^{\mathrm{b}}$ (B) cells were incubated for $20 \mathrm{~min}$ in the presence of varying concentrations ( $2 \mathrm{pM}$ to $2 \mu \mathrm{M})$ of target peptide, horse cyt $c$ p41-49, plus the competitor peptides, MI B chain p7-15 ( $\square$ ) and analogue p41-49/44A (ם), at a constant concentration of $10 \mu \mathrm{M}$. Additionally, ${ }^{51} \mathrm{Cr}$-labeled $\mathrm{L}+\mathrm{K}^{\mathrm{b}}$ and $\mathrm{L}+\mathrm{D}^{\mathrm{b}}$ target cells were incubated with $50 \mathrm{nM}$ of target peptide, horse cyt $c$ p41-49 (•), or media (O) alone as positive and negative controls for these experiments. After peptide incubation, Clone B6.H-4.1c was added at an effector-to-target ratio of 3:1 for 4 h. Supernatants $(100 \mu l)$ were collected and cytolytic activity was represented by the "percent specific lysis". Spontaneous release of targets in the absence of CTL effectors was $<10 \%$ of maximum lysis by detergent in all experiments. A single representative of three separate experiments is shown. 

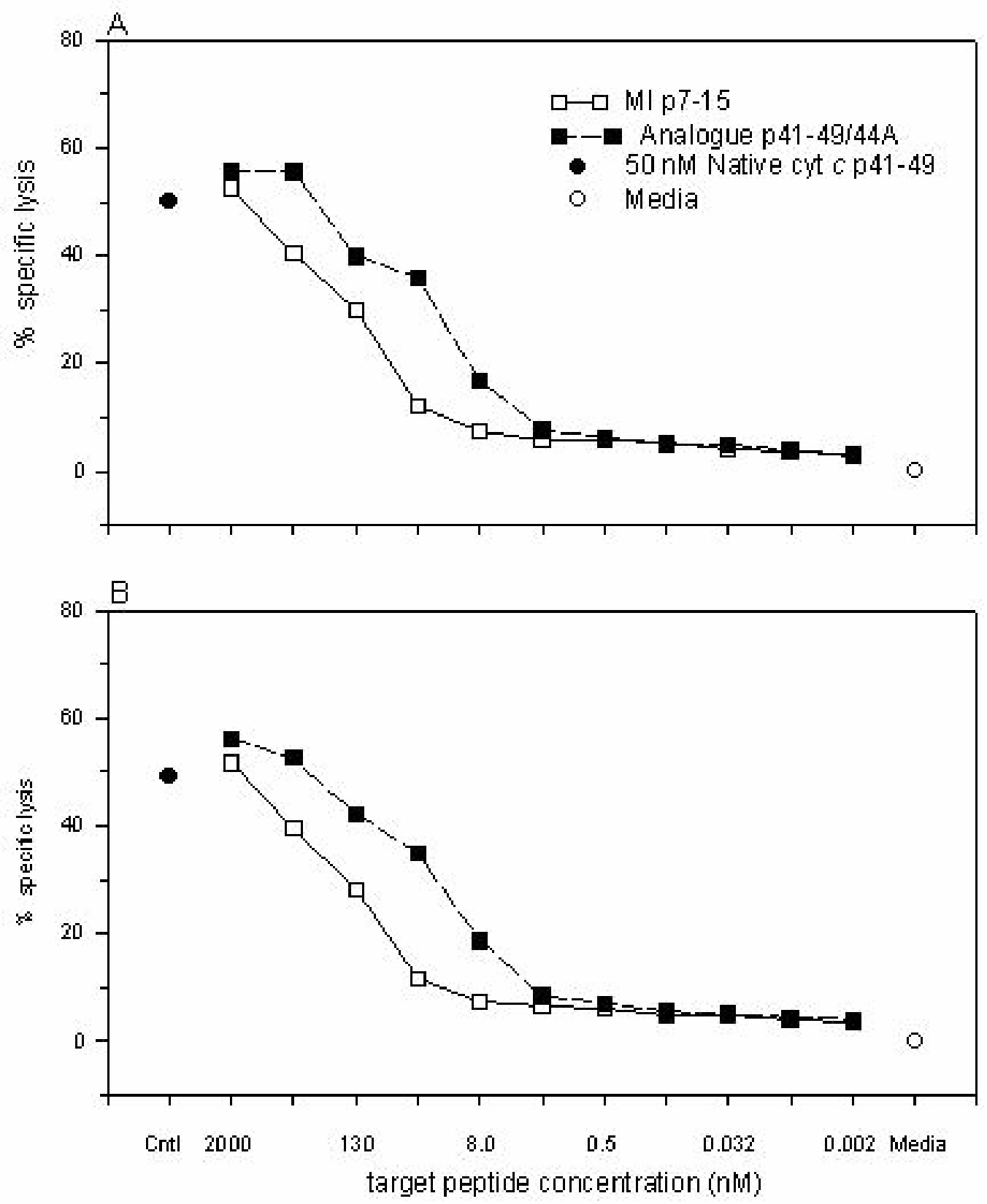
Fig. 5 Clone B6.H-4.1c responsiveness to analogue p41-49/45A is inhibited by the competitor peptides, MI B chain p7-15 and analogue p41-49/44A.

$\mathrm{L}+\mathrm{K}^{\mathrm{b}}(\mathrm{A})$ and $\mathrm{L}+\mathrm{D}^{\mathrm{b}}$ (B) cells were incubated for $20 \mathrm{~min}$ in the presence of varying concentrations ( $2 \mathrm{pM}$ to $2 \mu \mathrm{M}$ ) of target peptide, analogue $\mathrm{p} 41-49 / 45 \mathrm{~A}$, plus the competitor peptides, MI B chain p7-15 ( $\square$ ) and the analogue p41-49/44A (ם), at a constant concentration of $100 \mathrm{nM}$. Additionally, ${ }^{51} \mathrm{Cr}$-labeled $\mathrm{L}+\mathrm{K}^{\mathrm{b}}$ and $\mathrm{L}+\mathrm{D}^{\mathrm{b}}$ target cells were incubated with $50 \mathrm{nM}$ of target peptide, analogue p41-49/45A ( $\mathbf{\Delta})$, or media (O) alone as positive and negative controls for these experiments. After peptide incubation, Clone B6.H-4.1c was added at an effector-to-target ratio of $3: 1$ for $4 \mathrm{~h}$. Supernatants $(100 \mu \mathrm{l})$ were collected and cytolytic activity was represented by the "percent specific lysis". Spontaneous release of targets in the absence of CTL effectors was $<10 \%$ of maximum lysis by detergent in all experiments. A single representative of three separate experiments is shown. 

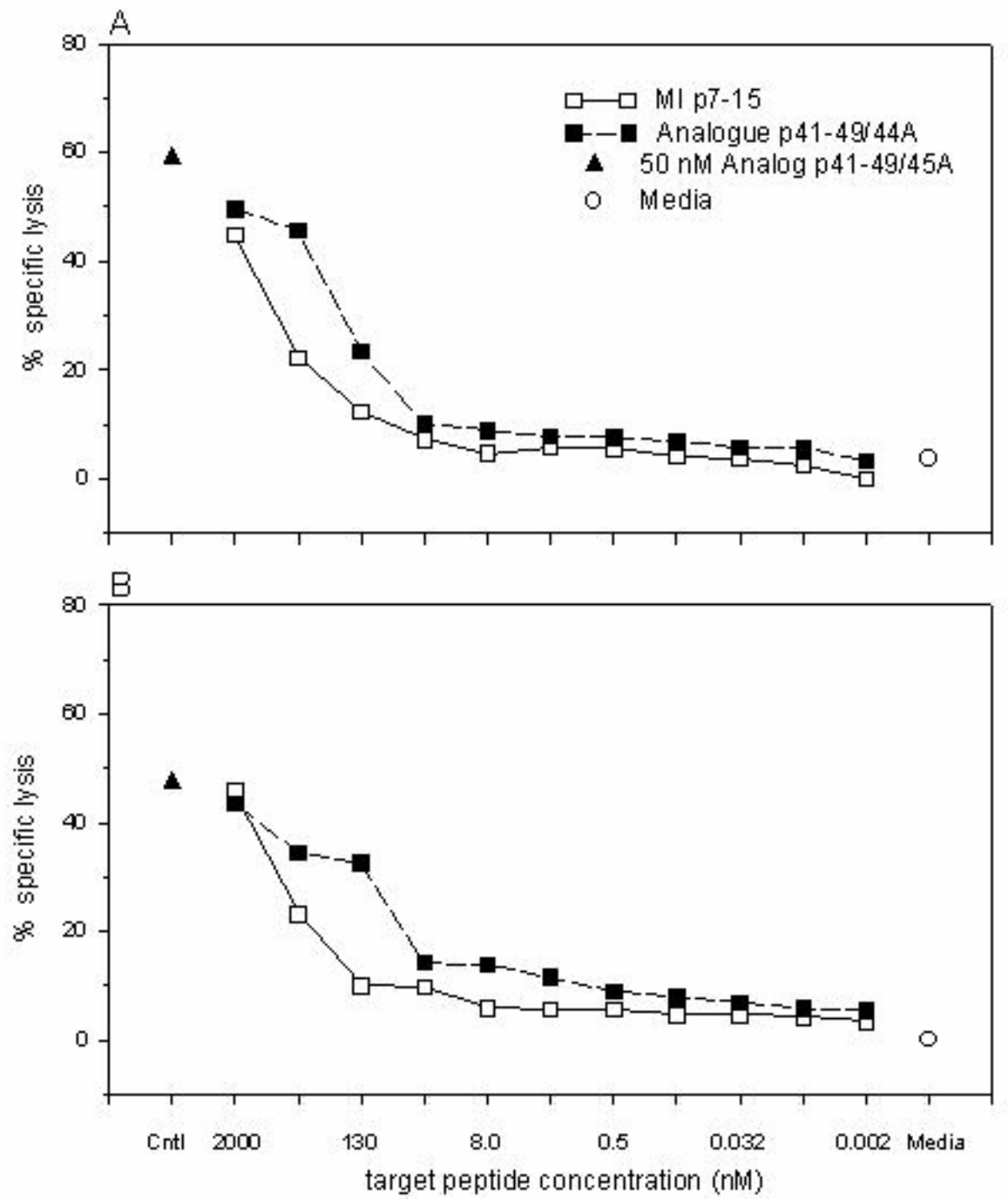
Fig. 6 Essential TCR contacts with horse cyt $c$ p41-49 are disrupted by the single amino substitution (Pro ${ }^{44} \rightarrow$ Ala), thus abrogating Clone B6.H-4.1c recognition.

The target peptides, horse cyt $c$ p41-49 (blue), analogue p41-49/44A (green) and analogue p41-49/45A (red), were introduced into the antigen-binding site of $\mathrm{H}-2 \mathrm{~K}^{\mathrm{b}}$ (A) and $\mathrm{H}-2 \mathrm{D}^{\mathrm{b}}$ (B) by single step substitution using $\mathrm{x}$-ray crystal structure coordinates determined for $\mathrm{H}-2 \mathrm{~K}^{\mathrm{b}}$ complexed with SEV-9 (PDB 1vab) and H-2D ${ }^{\mathrm{b}}$ complexed with influenza A p366-374 (PDB 1hoc). Each molecular model was represented as viewed from above the peptide-binding cleft $(\mathrm{A}$ and $\mathrm{B})$ and as a side view $(\mathrm{C}$ and $\mathrm{D})$. The peptides are represented as stick figures and individually colored. Molecular models were generated using a UNIX-based computer with QUANTA/CHARMm software packaging designed by Molecular Simulations, Inc. 

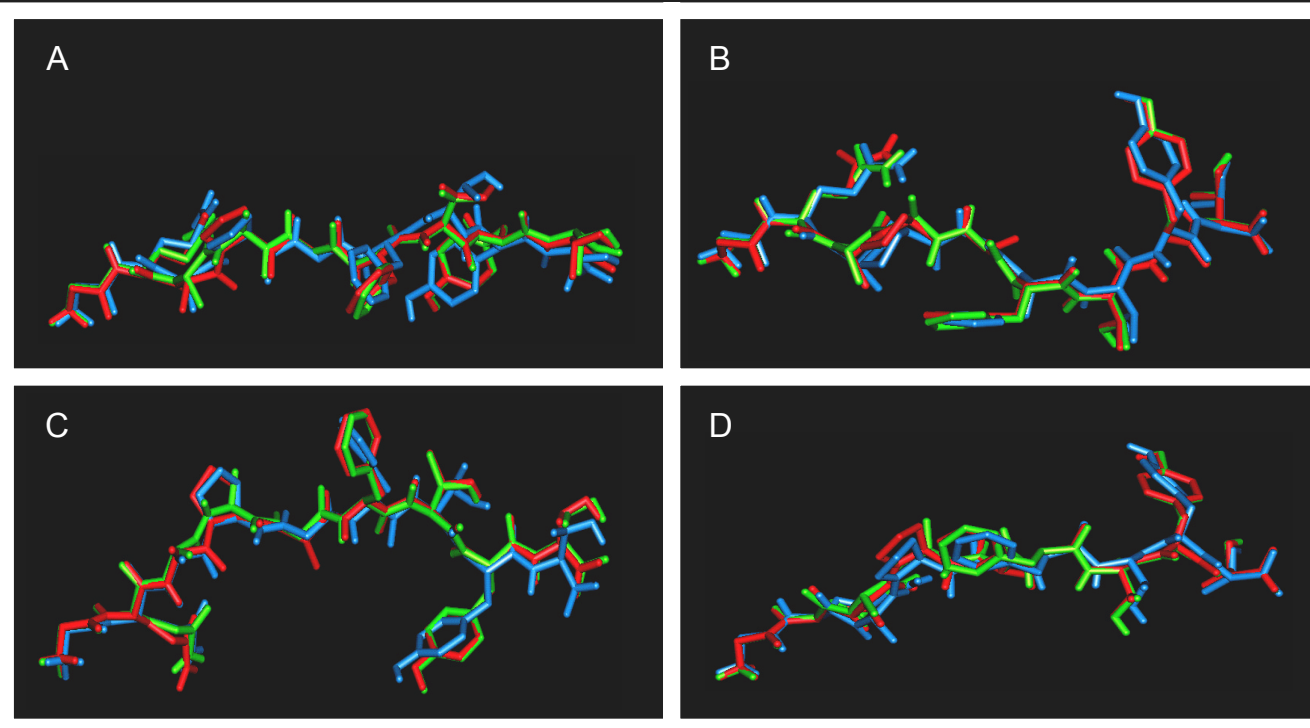

Horse cyt $c$ p41-49

Analog cyt $c$ p41-49/44A

Analog cyt $c$ p41-49/45A 


\section{REFERENCES}

1. Bevan, M. J. 1975. The major histocompatibility complex determines susceptibility to cytotoxic $\mathrm{T}$ cells directed against minor histocompatibility antigens. J Exp.Med. $142: 1349-1364$.

2. Bevan, M. J. 1977. Killer cells reactive to altered-self antigens can also be alloreactive. Proc.Natl.Acad.Sci.U.S.A 74:2094-2098.

3. Doherty, P. C. and R. M. Zinernagel. 1975. Capacity of sensitized thymus-derived lymphocytes to induce fatal lymphocytic choriomeningitis is restricted by the H-2 gene complex. J Immunol. 114:30-33.

4. Doherty, P. C. and R. M. Zinkernagel. 1975. Enhanced immunological surveillance in mice heterozygous at the H-2 gene complex. Nature 256:50-52.

5. Zinkernagel, R. M. and P. C. Doherty. 1997. The discovery of MHC restriction. Immunol.Today 18:14-17.

6. Paradela, A., M. Garcia-Peydro, J. Vazquez, D. Rognan, and J. A. Lopez de Castro. 1998. The same natural ligand is involved in allorecognition of multiple HLA-B27 subtypes by a single $\mathrm{T}$ cell clone: role of peptide and the MHC molecule in alloreactivity. J Immunol. 161:5481-5490.

7. Rivoltini, L., D. J. Loftus, K. Barracchini, F. Arienti, A. Mazzocchi, W. E. Biddison, M. L. Salgaller, E. Appella, G. Parmiani, and F. M. Marincola. 1996. Binding and presentation of peptides derived from melanoma antigens MART-1 and glycoprotein- 
100 by HLA-A2 subtypes. Implications for peptide-based immunotherapy. $J$ Immunol. 156:3882-3891.

8. Sheil, J. M., S. E. Shepherd, G. F. Klimo, and Y. Paterson. 1992. Identification of an autologous insulin $\mathrm{B}$ chain peptide as a target antigen for $\mathrm{H}-2 \mathrm{~K}^{\mathrm{b}}$-restricted cytotoxic T lymphocytes. J Exp.Med. 175:545-552.

9. Sheil, J. M., T. D. Schell, S. E. Shepherd, G. F. Klimo, J. M. Kioschos, and Y. Paterson. 1994. Presentation of a horse cytochrome c peptide by multiple $\mathrm{H}-2^{\mathrm{b}}$ class I major histocompatibility complex (MHC) molecules to C57BL/6- and bm1-derived cytotoxic T lymphocytes: presence of a single MHC anchor residue may confer efficient peptide-specific CTL recognition. Eur.J Immunol. 24:2141-2149.

10. Tallquist, M. D., T. J. Yun, and L. R. Pease. 1996. A single T cell receptor recognizes structurally distinct $\mathrm{MHC} /$ peptide complexes with high specificity. $J$ Exp.Med. 184:1017-1026.

11. Tallquist, M. D., A. J. Weaver, and L. R. Pease. 1998. Degenerate recognition of alloantigenic peptides on a positive-selecting class I molecule. J Immunol. 160:802809.

12. Threlkeld, S. C., P. A. Wentworth, S. A. Kalams, B. M. Wilkes, D. J. Ruhl, E. Keogh, J. Sidney, S. Southwood, B. D. Walker, and A. Sette. 1997. Degenerate and promiscuous recognition by CTL of peptides presented by the MHC class I A3-like superfamily: implications for vaccine development. J Immunol. 159:1648-1657. 
13. Calbo, S., G. Guichard, P. Bousso, S. Muller, P. Kourilsky, J. P. Briand, and J. P. Abastado. 1999. Role of peptide backbone in $\mathrm{T}$ cell recognition. J Immunol. $162: 4657-4662$.

14. Hemmer, B., M. Vergelli, C. Pinilla, R. Houghten, and R. Martin. 1998. Probing degeneracy in T-cell recognition using peptide combinatorial libraries. Immunol.Today 19:163-168.

15. Jameson, S. C., K. A. Hogquist, and M. J. Bevan. 1995. Positive selection of thymocytes. Annu.Rev.Immunol. 13:93-126.

16. Sant'Angelo, D. B., P. G. Waterbury, B. E. Cohen, W. D. Martin, L. Van Kaer, A. C. Hayday, and C. A. Janeway, Jr. 1997. The imprint of intrathymic self-peptides on the mature T cell receptor repertoire. Immunity. 7:517-524.

17. von Boehmer, H. 1994. Positive selection of lymphocytes. Cell 76:219-228.

18. Ignatowicz, L., J. Kappler, and P. Marrack. 1996. The repertoire of T cells shaped by a single MHC/peptide ligand. Cell 84:521-529.

19. Pawlowski, T. J., M. D. Singleton, D. Y. Loh, R. Berg, and U. D. Staerz. 1996. Permissive recognition during positive selection. Eur.J Immunol. 26:851-857.

20. Garcia, K. C., M. Degano, L. R. Pease, M. Huang, P. A. Peterson, L. Teyton, and I. A. Wilson. 1998. Structural basis of plasticity in T cell receptor recognition of a self peptide-MHC antigen. Science 279:1166-1172. 
21. Sun, R., S. E. Shepherd, S. S. Geier, C. T. Thomson, J. M. Sheil, and S. G. Nathenson. 1995. Evidence that the antigen receptors of cytotoxic T lymphocytes interact with a common recognition pattern on the $\mathrm{H}-2 \mathrm{~K}^{\mathrm{b}}$ molecule. Immunity. 3:573582.

22. Sant'Angelo, D. B., G. Waterbury, P. Preston-Hurlburt, S. T. Yoon, R. Medzhitov, S. C. Hong, and C. A. Janeway, Jr. 1996. The specificity and orientation of a TCR to its peptide-MHC class II ligands. Immunity. 4:367-376.

23. Ding, Y. H., K. J. Smith, D. N. Garboczi, U. Utz, W. E. Biddison, and D. C. Wiley. 1998. Two human $\mathrm{T}$ cell receptors bind in a similar diagonal mode to the HLA-A2/Tax peptide complex using different TCR amino acids. Immunity. 8:403411.

24. Garboczi, D. N., P. Ghosh, U. Utz, Q. R. Fan, W. E. Biddison, and D. C. Wiley. 1996. Structure of the complex between human T-cell receptor, viral peptide and HLA-A2. Nature 384:134-141.

25. Speir, J. A., K. C. Garcia, A. Brunmark, M. Degano, P. A. Peterson, L. Teyton, and I. A. Wilson. 1998. Structural basis of $2 \mathrm{C}$ TCR allorecognition of $\mathrm{H}-2 \mathrm{~L}^{\mathrm{d}}$ peptide complexes. Immunity. 8:553-562.

26. Boesteanu, A., M. Brehm, L. M. Mylin, G. J. Christianson, S. S. Tevethia, D. C. Roopenian, and S. Joyce. 1998. A molecular basis for how a single TCR interfaces multiple ligands. J Immunol. 161:4719-4727. 
27. Deres, K., T. N. Schumacher, K. H. Wiesmuller, S. Stevanovic, G. Greiner, G. Jung, and H. L. Ploegh. 1992. Preferred size of peptides that bind to $H-2 K^{b}$ is sequence dependent. Eur.J Immunol. 22:1603-1608.

28. Neefjes, J. J., J. Dierx, and H. L. Ploegh. 1993. The effect of anchor residue modifications on the stability of major histocompatibility complex class I-peptide interactions. Eur.J Immunol. 23:840-845.

29. Saito, N. G. and Y. Paterson. 1997. Contribution of peptide backbone atoms to binding of an antigenic peptide to class I major histocompatibility complex molecule. Mol.Immunol. 34:1133-1145.

30. Deng, Y., J. W. Yewdell, L. C. Eisenlohr, and J. R. Bennink. 1997. MHC affinity, peptide liberation, $\mathrm{T}$ cell repertoire, and immunodominance all contribute to the paucity of MHC class I-restricted peptides recognized by antiviral CTL. J Immunol. $158: 1507-1515$.

31. Schumacher, T. N., M. T. Heemels, J. J. Neefjes, W. M. Kast, C. J. Melief, and H. L. Ploegh. 1990. Direct binding of peptide to empty MHC class I molecules on intact cells and in vitro. Cell 62:563-567.

32. Franksson, L., M. Petersson, R. Kiessling, and K. Karre. 1993. Immunization against tumor and minor histocompatibility antigens by eluted cellular peptides loaded on antigen processing defective cells. Eur.J Immunol. 23:2606-2613. 
33. Ljunggren, H. G., N. J. Stam, C. Ohlen, J. J. Neefjes, P. Hoglund, M. T. Heemels, J. Bastin, T. N. Schumacher, A. Townsend, K. Karre, and . 1990. Empty MHC class I molecules come out in the cold. Nature 346:476-480.

34. Hammerling, G. J., E. Rusch, N. Tada, S. Kimura, and U. Hammerling. 1982. Localization of allodeterminants on $\mathrm{H}-2 \mathrm{~K}^{\mathrm{b}}$ antigens determined with monoclonal antibodies and H-2 mutant mice. Proc.Natl.Acad.Sci.U.S.A 79:4737-4741.

35. Hasenkrug, K. J., J. M. Cory, and J. H. Stimpfling. 1987. Monoclonal antibodies defining mouse tissue antigens encoded by the H-2 region. Immunogenetics 25:136139.

36. Feltkamp, M. C., M. P. Vierboom, R. E. Toes, F. Ossendorp, J. ter Schegget, C. J. Melief, and W. M. Kast. 1995. Competition inhibition of cytotoxic T-lymphocyte (CTL) lysis, a more sensitive method to identify candidate CTL epitopes than induction of antibody-detected MHC class I stabilization. Immunol.Lett. 47:1-8.

37. Fremont, D. H., M. Matsumura, E. A. Stura, P. A. Peterson, and I. A. Wilson. 1992. Crystal structures of two viral peptides in complex with murine MHC class I H-2 $\mathrm{K}^{\mathrm{b}}$. Science 257:919-927.

38. Stura, E. A., M. Matsumura, D. H. Fremont, Y. Saito, P. A. Peterson, and I. A. Wilson. 1992. Crystallization of murine major histocompatibility complex class I H-2K ${ }^{\mathrm{b}}$ with single peptides. $J$ Mol.Biol. 228:975-982. 
39. Young, A. C., W. Zhang, J. C. Sacchettini, and S. G. Nathenson. 1994. The threedimensional structure of $\mathrm{H}-2 \mathrm{D}^{\mathrm{b}}$ at $2.4 \AA$ resolution: implications for antigendeterminant selection. Cell 76:39-50.

40. Falk, K., O. Rotzschke, S. Stevanovic, G. Jung, and H. G. Rammensee. 1991. Allelespecific motifs revealed by sequencing of self-peptides eluted from MHC molecules. Nature 351:290-296.

41. Chandrasekhar, K., A. T. Profy, and H. J. Dyson. 1991. Solution conformational preferences of immunogenic peptides derived from the principal neutralizing determinant of the HIV-1 envelope glycoprotein gp120. Biochemistry 30:9187-9194.

42. Motoshima, H., T. Ueda, Y. Hashimoto, M. Tsutsumi, and T. Imoto. 1995. Correlation between the differences in the free energy change and conformational energy in the folded state of hen lysozymes with Gly-Pro and Pro-Gly sequences introduced to the same site. J Biochem.(Tokyo) 118:1138-1144.

43. Fetrow, J. S., J. S. Spitzer, B. M. Gilden, S. J. Mellender, T. J. Begley, B. J. Haas, and T. L. Boose. 1998. Structure, function, and temperature sensitivity of directed, random mutants at proline 76 and glycine 77 in omega-loop D of yeast iso-1cytochrome c. Biochemistry 37:2477-2487.

44. Brett, S. J., D. McKean, J. York-Jolley, and J. A. Berzofsky. 1989. Antigen presentation to specific $\mathrm{T}$ cells by Ia molecules selectively altered by site-directed mutagenesis. Int.Immunol. 1:130-140. 
45. Krieger, J. I., R. W. Karr, H. M. Grey, W. Y. Yu, D. O'Sullivan, L. Batovsky, Z. L. Zheng, S. M. Colon, F. C. Gaeta, J. Sidney, and . 1991. Single amino acid changes in DR and antigen define residues critical for peptide-MHC binding and $\mathrm{T}$ cell recognition. J Immunol. 146:2331-2340.

46. McMichael, A. J., F. M. Gotch, J. Santos-Aguado, and J. L. Strominger. 1988. Effect of mutations and variations of HLA-A2 on recognition of a virus peptide epitope by cytotoxic T lymphocytes. Proc.Natl.Acad.Sci.U.S.A 85:9194-9198.

47. Peccoud, J., P. Dellabona, P. Allen, C. Benoist, and D. Mathis. 1990. Delineation of antigen contact residues on an MHC class II molecule. EMBO J 9:4215-4223.

48. Engelhard, V. H. 1994. Structure of peptides associated with MHC class I molecules. Curr.Opin.Immunol. 6:13-23.

49. Momburg, F., J. Roelse, G. J. Hammerling, and J. J. Neefjes. 1994. Peptide size selection by the major histocompatibility complex-encoded peptide transporter. $J$ Exp.Med. 179:1613-1623.

50. Schumacher, T. N., D. V. Kantesaria, M. T. Heemels, P. G. Ashton-Rickardt, J. C. Shepherd, K. Fruh, Y. Yang, P. A. Peterson, S. Tonegawa, and H. L. Ploegh. 1994. Peptide length and sequence specificity of the mouse TAP1/TAP2 translocator. $J$ Exp.Med. 179:533-540. 


\title{
CHAPTER 4
}

Depletion of $\mathrm{V}_{\beta} 9^{+}$and $\mathrm{V}_{\beta} 12^{+} \mathrm{CTLs}$ in vitro abrogates the bm19 anti-C57BL/6 alloreactive response without impairing antigen-specific CTL reactivity

\author{
Marc A. Frankenberry ${ }^{1}$, William Tarry ${ }^{2}$, and James M. Sheil ${ }^{1}$
}

Department of Microbiology, Immunology \& Cell Biology ${ }^{1}$, Department of Surgery ${ }^{2}$, West Virginia University School of Medicine, Morgantown, WV 26506-9177 


\begin{abstract}
The success of clinical transplantation is largely dependent upon the development of immunosuppressive treatment regimens using prednisone, cyclosporine $\mathrm{A}$ and tacrolimus (also called FK506). One concern with such therapeutic interventions is their adverse impact on the recipient's overall immune status due to a generalized inhibition of $\mathrm{T}$ cell responsiveness. To circumvent this problem, we proposed to distinguish and remove allospecific CTLs from the $\mathrm{T}$ cell repertoire, based on TCR $\mathrm{V}_{\beta}$ family usage. Using a panel of mAbs specific for 14 distinct TCR $V_{\beta}$ families, accounting for $>95 \%$ of splenic $\mathrm{T}$ cells, we show the expansion of $\mathrm{CD}^{+} \mathrm{V}_{\beta}$ families - 8.1/8.2, 9, 10, 12, and 14 in bm19 anti-C57BL/6 cultures. Analysis of the functional reactivity of $\mathrm{CD}^{+} \mathrm{T}$ cells from these families, however, implicates only bm19 $\mathrm{V}_{\beta} 9^{+}$and $\mathrm{V}_{\beta} 12^{+} \mathrm{CTLs}$ as effective alloreactive responders against $\mathrm{H}-2 \mathrm{~K}^{\mathrm{b}}$-expressing targets. Thus, for bm19 CTLs stimulated in vitro with B6 spleen cells, $\mathrm{K}^{\mathrm{b}}$-specific alloreactivity resides largely, if not completely, within both $\mathrm{V}_{\beta} 9$ and $\mathrm{V}_{\beta} 12$ families. Importantly, after removing both $\mathrm{V}_{\beta} 9$ and $\mathrm{V}_{\beta} 12$ alloreactive CTLs, the remaining CTLs are still fully responsive to other $\mathrm{K}^{\mathrm{b}}$-restricted antigens, as shown by their reactivity to VSV-8 and insulin B chain $\mathrm{p} 7-15$ peptides, and to unrelated $\mathrm{H}-2^{\mathrm{d}}$ alloantigens. This study constitutes the first demonstration of the synergistic effects of two CTL $V_{\beta}$ families on alloreactivity. Furthermore, these findings suggest that removal of transplant-specific, alloreactive CTLs in vivo may be an effective means to diminish the reliance on nonspecific immunosuppressive drugs in the post-transplantation setting.
\end{abstract}




\section{INTRODUCTION}

The clinical use of immunosuppressive drugs as a successful therapy to prevent graft rejection in transplantation is accompanied by adverse side effects on the overall immune status of transplant patients, with the long-term use of these drugs leading to a diminished overall quality of life. Owing in part to a generalized suppression of $\mathrm{T}$ cell responsiveness in these patients, cell-mediated immunity is compromised by the very drugs administered to overcome the $\mathrm{T}$ cell mediated rejection of transplanted tissues and organs (1-4). In this study, we first asked whether a single $T$ cell receptor (TCR) $V_{\beta}$ family is responsible for the alloreactive cytotoxic $\mathrm{T}$ lymphocyte (CTL) response in a class I major histocompatibility complex (MHC) disparate mouse model. Secondly, we addressed whether removing this $\mathrm{V}_{\beta}$ family could lead to abrogation of the in vitro alloreactive CTL response, without compromising the cell-mediated immune response to other foreign antigens.

Acute allograft rejection and graft-versus-host disease (GVHD) are mediated by alloreactive $\mathrm{T}$ lymphocytes, including $\mathrm{CD} 8^{+} \mathrm{CTLs}$ that respond to foreign class I MHC molecules on engrafted donor tissue (5-9). Alloreactive CTLs express a membrane bound TCR that interacts with the complex of a small peptide bound to the antigen binding cleft on the distal surface of a class I MHC molecule $(10,11)$. The TCR is a disulfide-linked heterodimeric glycoprotein formed by the somatic recombination of $\alpha$ and $\beta$ chain $\mathrm{V}-(\mathrm{D})-\mathrm{J}$ segments $(11,12)$ and is able to recognize potential foreign MHC/peptide complexes (13).

The myriad of possible TCR $\alpha$ and $\beta$ chain combinations can theoretically

generate a highly diverse CTL population comprised of a wide range of TCR 
specificities. Despite the findings of some studies describing the random use of TCR $V_{\beta}$ regions for $\mathrm{T}$ cells involved in alloreactive responses $(14,15)$, considerable evidence indicates there is a preference for the biased usage of certain TCR $V_{\beta}$ families in both human (16-19) and murine (20-23) alloreactive T cell responses.

Studies by Grandea III and Bevan (24) using the MHC class I H-2K ${ }^{\mathrm{b}}$ transgenic mouse mutant, $\mathrm{H}-2 \mathrm{~K}^{\mathrm{b}, \mathrm{E} 65}$, suggest that even a single amino acid disparity in the $\mathrm{H}-2 \mathrm{~K}^{\mathrm{b}}$ molecule can generate a strong alloreactive CTL response. This transgenic mouse has a solitary amino acid substitution at position $65\left(\mathrm{Gln}^{65} \rightarrow \mathrm{Glu}\right)$ located on the outward face of the $\alpha$-helix of the $\alpha 1$ domain that interacts with the TCR but does not affect the peptide-binding groove (24). Strong $\mathrm{H}-2 \mathrm{~K}^{\mathrm{b}, \mathrm{E} 65}$ alloreactive $\mathrm{CTL}$ responses are generated against the wild-type $\mathrm{K}^{\mathrm{b}}$-expressing target cell line and against several mutant target cells, including $\mathrm{H}-2 \mathrm{~K}^{\mathrm{b}, \mathrm{D} 65}\left(\mathrm{Gln}^{65} \rightarrow \mathrm{Asp}\right), \mathrm{H}-2 \mathrm{~K}^{\mathrm{b}, \mathrm{R} 65}\left(\mathrm{Gln}^{65} \rightarrow \mathrm{Arg}\right)$ and $\mathrm{H}-2 \mathrm{~K}^{\mathrm{b}, \mathrm{V} 65}$ $\left(\mathrm{Gln}^{65} \rightarrow \mathrm{Val}\right)$. These findings suggest that cross-reactive $\mathrm{T}$ cells may have a higher TCR affinity for nonconserved amino acid changes (24). In the present study, designed to assess the extent of TCR $V_{\beta}$ family usage among alloreactive CTLs, we selected the B6derived mutant mouse model, designated bm19 $(25,26)$, that has only a single amino acid substitution at position $80\left(\mathrm{Thr}^{80} \rightarrow\right.$ Asn) of the $\mathrm{H}-2 \mathrm{~K}^{\mathrm{b}}$ molecule to evaluate specific bm19 CD8 ${ }^{+}$TCR $V_{\beta}$ families involved in the CTL response to $\mathrm{H}-2 \mathrm{~K}^{\mathrm{b}}$.

Using a similar approach, Connolly and coworkers (27) evaluated the primary $\mathrm{L}^{\mathrm{d}}-$ specific CTL response of the $\mathrm{L}^{\mathrm{d}}$-loss mutant, $\mathrm{dm} 2$, when stimulated with irradiated wildtype BALB/c spleen cells. Their results implicated $\mathrm{V}_{\beta} 8^{+}$alloreactive CTLs as effectors of the $L^{d}$-specific response. The addition of the anti- $V_{\beta} 8$ monoclonal antibody (mAb), 
F23.1, to a standard $4-\mathrm{h}{ }^{51} \mathrm{Cr}$-release assay diminished the $\mathrm{H}-2 \mathrm{~L}^{\mathrm{d}}$-specific CTL response by approximately $80 \%(27)$.

We established one-way mixed lymphocyte cultures (MLC) using spleen cells from the mutant mouse strain B6.H-2 ${ }^{\mathrm{bm} 19}$ (bm19) (26) and the parental strain, C57BL/6 (B6). Mice from the bm19 mutant strain differ from the B6 parental strain by a single amino acid substitution (Thr ${ }^{80} \rightarrow$ Asn) located on the distal surface of the $\mathrm{H}-2 \mathrm{~K}^{\mathrm{b}} \alpha 1$ helix (28). In this study, we employed a panel of 14 different TCR $V_{\beta}$-specific mAbs from Pharmingen $($ (Becton-Dickinson, Mountain View, CA) to distinguish alloreactive CTLs based on their expression of distinct $V_{\beta}$ regions. We utilized flow cytometry to identify five distinct $\mathrm{CD}^{+} \mathrm{V}_{\beta}$ families that are expanded in both short- and long-term bm19 antiB6 MLC. Selective removal of preferentially expanded bm19 anti-B6 CTLs, by indirect panning in vitro, abrogates alloreactivity against $\mathrm{H}-2 \mathrm{~K}^{\mathrm{b}}$-bearing target cells. Furthermore, depletion of these bm19 anti-B6 CTLs did not impair the antigen-specific response of bm19 CTLs to the immunogenic peptides, vesicular stomatitis virus nucleoprotein p52-59 (VSV-8) $(29,30)$ and mouse insulin I (MI) B chain p7-15 (31), nor to unrelated $\mathrm{H}-2^{\mathrm{d}}$ alloantigens. Thus, the removal of $\mathrm{V}_{\beta}$ families in vivo should significantly prolong allograft survival. An important advantage of this approach over conventional immunosuppressive drug regimens lies in its preservation of normal cell mediated immune mechanisms. 


\section{MATERIAL AND METHODS}

\section{Animals}

Female B6 and bm19 mice (26) used in this study were obtained from this laboratory's breeding colony at West Virginia University Health Sciences Center Vivarium. The B6 and bm19 breeding colonies were established in 1987 and have been maintained since then at the West Virginia University Health Sciences Center Vivarium. All female mice used in this study were 8-12 wks of age.

\section{Target cell lines}

The hybridoma cell line, SP2/0 AG.14 (SP2/0) (H-2 $\left.{ }^{\mathrm{d}}\right)(32,33)$, was used as a fusion partner for generating S.B6 and S.bm19 T cell hybridoma targets. These hybridomas were generated in our laboratory, and appropriate $\mathrm{H}-2^{\mathrm{b}}$ class I expression was verified by flow cytometric analysis (data not shown). The murine T lymphoma cell line, EL-4 $\left(H-2^{b}\right)(34,35)$ and mastocytoma cell line, P815 $\left(H-2^{d}\right)(35,36)$ were used as targets for ${ }^{51} \mathrm{Cr}$-release assays to measure CTL-mediated lysis. These cell lines were grown as suspension cultures in RP-10 (RPMI-1640 media supplemented with 10\% FCS, 100 mM HEPES, $100 \mathrm{U} / \mathrm{ml}$ penicillin, $100 \mu \mathrm{g} / \mathrm{ml}$ streptomycin and $2 \mathrm{mM}$ L-glutamine), as previously described (37). 


\section{Synthesis of peptides}

Peptides, VSV-8 [R-G-Y-V-Y-Q-G-L] and MI B chain p7-15 [C-G-S-H-L-V-E-A-L], synthesized by fMoc chemistry using an automated peptide synthesizer (9050 MilliGen PepSynthesizer) as previously described (30), were generously provided by Drs. J. W. Yewdell and J. R. Bennink. Amino acid composition and purity was determined by HPLC tracing (Waters 600E) and the Pico Tag Amino Acid Analysis System (Waters) (J. W. Yewdell and J. R. Bennink, personal communication). Lyophilized peptides were solubilized in sterile 1X PBS at appropriate stock concentrations.

Antibodies and flow cytometric analysis

Phycoerythin (PE)-conjugated anti-CD8 $\alpha$ mAb [designated 53-6.7] (38) and fluorescein isothiocyanate (FITC)-conjugated anti- $\mathrm{V}_{\beta} 2 \mathrm{mAb}[\mathrm{B} 20.6]$ (39), anti- $\mathrm{V}_{\beta} 4 \mathrm{mAb}$ [KT4] (40), anti- $\mathrm{V}_{\beta} 5.1 / 2 \mathrm{mAb}$ [MR9-4] (41), anti- $\mathrm{V}_{\beta} 6 \mathrm{mAb}$ [RR4-7] (42), anti- $\mathrm{V}_{\beta} 7 \mathrm{mAb}$ [TR310] (43), anti- $\mathrm{V}_{\beta} 8.1 / 8.2 \mathrm{mAb}[\mathrm{F} 23.1](44)$, anti- $\mathrm{V}_{\beta} 8.3 \mathrm{mAb}$ [1B3.3] (45), anti- $\mathrm{V}_{\beta} 9 \mathrm{mAb}$ [MR10-2] (45), anti- $\mathrm{V}_{\beta} 10^{\mathrm{b}} \mathrm{mAb}$ [B21.5] (39), anti- $\mathrm{V}_{\beta} 11 \mathrm{mAb}$ [RR3-15] (46), anti- $\mathrm{V}_{\beta} 12$ $\mathrm{mAb}$ [MR11-1] (45), anti- $\mathrm{V}_{\beta} 13 \mathrm{mAb}$ [MR12-3] (45), anti- $\mathrm{V}_{\beta} 14 \mathrm{mAb}$ [14-2] (47), and anti- $\mathrm{V}_{\beta} 17^{\mathrm{a}} \mathrm{mAb}[\mathrm{KJ} 23]$ (48) were purchased from Pharmingen $\odot$ (Becton Dickinson, Mountain View, CA). Effector cells $\left(5 \times 10^{5}\right)$ were incubated for 45 min on ice with 20 $\mu \mathrm{l}(1: 100)$ of each of the 14 FITC-conjugated anti-TCR $V_{\beta}$-specific mAb and $20 \mu \mathrm{l}(1: 96)$ of PE-conjugated anti-CD8 $\alpha$ mAb, washed twice with 1X PBS and fixed in $500 \mu 1 \%$ formalin. Fixed cells were analyzed for fluorescence intensity using a FACScan ${ }^{\circledR}$ flow cytometer (Becton Dickinson, Mountain View, CA). Percent $V_{\beta}$ expression of 
alloreactive CTLs was defined as $100 \mathrm{X}\left(\mathrm{V}_{\beta \mathrm{n}}\right.$ value/sum of $\mathrm{V}_{\beta}$ values), as described previously (49).

Short- and long-term alloreactive $M L C$

Alloreactive CTL lines were generated as previously described $(31,50)$ with the following modifications: The initial priming $\left(1^{\circ}\right)$ of bm19 anti-B6 MLC was accomplished by culturing $2.5 \times 10^{7}$ female bm19 spleen cells with $2.5 \times 10^{7}$ irradiated (3000 rads) stimulator splenocytes from female B6 mice. $1^{\circ}$ bm19 anti-B6 MLCs were maintained in $10 \mathrm{ml} \mathrm{RP}-10$ per flask for 7 days at $37^{\circ} \mathrm{C}$ with $7 \% \mathrm{CO}_{2}$ and $95 \%$ humidity in upright $25-\mathrm{cm}^{2}$ tissue culture treated (T-25) flasks (Costar $\left.\complement\right)$. Short-term $\left(2^{\circ}\right)$ alloreactive MLC were established by culturing $5 \times 10^{6}$ effector splenocytes from $1^{\circ}$ bm19 anti-B6 MLC with $2.5 \times 10^{7}$ irradiated splenocytes from female B6 mice on day 7 . Secondary $\left(2^{\circ}\right)$ bm19 anti-B6 MLC were maintained under the same conditions as described for the $1^{\circ}$ bm19 anti-B6 MLCs. Subsequent long-term alloreactive MLCs were established by culturing $4 \times 10^{5}$ effector splenocytes from previous bm19 anti-B6 MLC with $5 \times 10^{6}$ irradiated female B6 splenocytes on day 7. Each long-term MLC was supplemented with 5\% interleukin-2 (IL-2)-enriched rat concanavalin A supernatant (ConA SN) and 5\% 1M $\alpha$-methyl mannoside ( $\alpha-M M)$. Long-term bm19 anti-B6 MLCs were maintained in a 24well cell culture cluster plate $(\operatorname{Costar} \odot)$ at $37^{\circ} \mathrm{C}$ with $7 \% \mathrm{CO}_{2}$ and $95 \%$ humidity.

Analysis of in vitro T cell proliferation

The proliferative capacities of $1^{\circ}$ bm19 anti-BALB/c, bm19 anti-VSV-8 and bm19 anti-MI B chain p7-15 CTLs, were determined on day 4 by measuring the incorporation 
of ${ }^{3} \mathrm{H}-\mathrm{TdR}(51)$. Briefly, $5 \times 10^{5} \mathrm{bm} 19$ anti-BALB/c, bm19 anti-VSV-8 $(29,30)$ and bm19 anti-MI B chain p7-15 (37) effector cells were incubated in $100 \mu 1$ volume of RP10 plus $2 \mu \mathrm{Ci}$ tritiated thymidine $\left[{ }^{3} \mathrm{H}-\mathrm{TdR}\right]$ in a 96 -well U-bottom plate for $18 \mathrm{~h}$. All assays were performed in triplicate. After incubation, cells were harvested using a Cambridge Technology, Inc. PHD Cell Harvester (Cambridge, MA), and ${ }^{3} \mathrm{H}-\mathrm{TdR}$ incorporation was measured on a Wallac 1410 Liquid Scintillation Counter (Wallac, Gaithersburg, MD).

\section{Analysis of in vitro CTL lytic activity}

The lytic activity of bm19 anti-B6 MLC-derived CTLs was assayed in vitro on day 5 using a standard $4-\mathrm{h}{ }^{51} \mathrm{Cr}$-release assay, as described previously (52). Briefly, 1 X $10^{6}$ SP2/0, S.B6 or S.bm19 target cells were incubated in $50 \mu 1 \mathrm{RP}-10$ media $+100 \mu \mathrm{Ci}$ sodium chromate $51\left({ }^{51} \mathrm{Cr}\right.$; New England Nuclear, Boston, MA) / $10^{6}$ cells for $60 \mathrm{~min}$ at $37^{\circ} \mathrm{C} 7 \% \mathrm{CO}_{2}$, washed in $1 \mathrm{X}$ HBSS and resuspended in $10 \mathrm{ml} \mathrm{RP}-10$. Following a 30 min incubation at $37^{\circ} \mathrm{C}$, target cells were washed in $1 \mathrm{X}$ HBSS and resuspended in RP-10 media at a final concentration of $2 \times 10^{5}$ cells $/ \mathrm{ml}$. Target cells were added in $50 \mu \mathrm{l} /$ well RP-10 to 96-well round-bottom microtiter plates. Exogenous peptides to be tested were added in $50 \mu \mathrm{l} /$ well RP-10, with a final concentration of $2 \mu \mathrm{M}$, and incubated for $20 \mathrm{~min}$ at $37^{\circ} \mathrm{C}, 7 \% \mathrm{CO}_{2}$. In the absence of exogenous peptides, target cells were added to each well at a final concentration of $1 \times 10^{4}$ cells/200 $\mu$ l. Effector cells from bm19 anti-B6 MLCs were added at effector-to-target ratios of 100:1, 50:1, 25:1 12.5:1, 6.3:1 and 3.1:1. Assay plates were incubated for $4 \mathrm{~h}$ at $37^{\circ} \mathrm{C}, 7 \% \mathrm{CO}_{2}$ and centrifuged for 7 min at 1200 rpm. Supernatants $(100 \mu \mathrm{l})$ were collected from each well and transferred to 6 X $50 \mathrm{~mm}$ 
tubes for determination of total ${ }^{51} \mathrm{Cr}$ counts on an LKB Clinigamma Model 1272 counter (LKB Instruments, Finland).

The "percent specific lysis" value for ${ }^{51} \mathrm{Cr}$-release assay results was determined as follows:

experimental cpm - spontaneous cpm

maximum - spontaneous cpm

Spontaneous release values of targets in the absence of CTL effectors were $<10 \%$ of maximum lysis by detergent in all experiments. Cytolytic activity is represented as lytic units (LU), where one LU is equal to the number of alloreactive CTLs (X 10 ${ }^{4}$ ) required to generate $30 \%$ lysis of a given target cell (53).

\section{Indirect T cell panning}

Falcon 1005 OPTILUX petri dishes were pre-coated with $10 \mu \mathrm{g} / \mathrm{ml}$ goat anti-mouse IgG, goat anti-rat IgG, or goat anti-rat IgM in $50 \mathrm{mM}$ Tris buffer, $\mathrm{pH} 9.5$ at a final volume of $10 \mathrm{ml}$. Plates were incubated overnight at $4^{\circ} \mathrm{C}$, washed $3 \mathrm{X}$ with cold $1 \mathrm{X}$ PBS supplemented with $1 \%$ FCS (1\% PBS) and stored at $4^{\circ} \mathrm{C}$ in $15 \mathrm{ml} \mathrm{1 \%}$ PBS. Spleen cells from female bm19 mice were depleted of red blood cells with $0.17 \mathrm{M}$ Tris-buffered $0.16 \mathrm{M} \mathrm{NH}_{4} \mathrm{Cl}$ at $\mathrm{pH} 7.2$, washed $2 \mathrm{X}$ with HBSS and enriched for $\mathrm{T}$ cells by nylon wool column exclusion $(54,55)$. After $\mathrm{T}$ cell enrichment, cells were resuspended at $1 \times 10^{6}$ cells $/ \mathrm{ml}$ in $1 \mathrm{X}$ PBS and incubated with $1 \mu \mathrm{g} / \mathrm{ml}$ unconjugated mouse $\operatorname{IgG}_{2 \mathrm{a}}$ anti- $\mathrm{V}_{\beta} 8.1 / 8.2$ [F23.1], mouse $\operatorname{IgG}_{1}$ anti- $\mathrm{V}_{\beta} 9$ [MR10-2], rat $\operatorname{IgG}_{2 \mathrm{a}}$ anti- $\mathrm{V}_{\beta} 10^{\mathrm{b}}$ [B21.5], mouse $\mathrm{IgG}_{1}$ anti$\mathrm{V}_{\beta} 12$ [MR11-1], rat IgM anti- $\mathrm{V}_{\beta} 14$ [14-2] and/or mouse $\operatorname{IgG}_{2 \mathrm{a}}$ anti- $\mathrm{V}_{\beta} 17$ [KJ23] mAb for $30 \mathrm{~min}$ at $4^{\circ} \mathrm{C}$. Cells were washed $3 \mathrm{X}$ and resuspended in $1 \% \mathrm{PBS}$, and incubated on 
appropriate pre-coated petri dishes at $4^{\circ} \mathrm{C}$ for 60 min with gentle shaking every $15 \mathrm{~min}$. Non-adherent cells $\left(\mathrm{V}_{\beta}{ }^{-}\right)$were collected, plates were washed with $5 \mathrm{ml}$ cold $1 \%$ PBS and adherent cells $\left(\mathrm{V}_{\beta}{ }^{+}\right)$were dislodged by gentle scraping with a rubber policeman. Recovered cells $\left(\mathrm{V}_{\beta}\right.$-enriched and $\mathrm{V}_{\beta}$-depleted) were washed twice in $5 \mathrm{ml} 1 \% \mathrm{PBS}$, and $5 \times 10^{5}$ cells were analyzed by flow cytometry as described above, for each $V_{\beta}$ family examined. After the cells were collected, $4 \times 10^{5} \mathrm{~V}_{\beta}$-enriched or $\mathrm{V}_{\beta}$-depleted cells were cultured with $5 \times 10^{6}$ irradiated B6 splenocytes and maintained for three wks in a 24-well cell culture cluster plate $(\operatorname{Costar} \odot)$. Cultures of $\mathrm{V}_{\beta}$-enriched and $\mathrm{V}_{\beta}$-depleted $3^{\circ}$ anti-B6 effectors were supplemented with 5\% IL-2-enriched rat Con A and 5\% 1M $\alpha-\mathrm{MM}$ and evaluated on day 5 for B6-specific alloreactivity in a $4-\mathrm{h}{ }^{51} \mathrm{Cr}$-release assay.

\section{Statistical analysis}

All statistics in this study were performed by one-way analysis of variance (ANOVA). Statistical significance, where indicated, is determined as $p<0.05$. 


\section{RESULTS}

Short-and long-term bm19 anti-B6 MLCs exhibit strong alloreactivity for $\mathrm{H}-2 \mathrm{~K}^{b}$-bearing target cells.

We first addressed whether a single amino acid difference in the $\mathrm{H}-2 \mathrm{~K}^{\mathrm{b}}$ molecules expressed by B6 and bm19 mice is sufficient to induce a strong alloreactive CTL response by assessing the lytic capacity of bm19 splenocytes stimulated with allogeneic B6 splenocytes. To determine the lytic capacity of short- and long-term MLCs generated against this single amino acid difference between the $\mathrm{K}^{\mathrm{b}}$ and $\mathrm{K}^{\mathrm{bm} 19}$ molecules $\left(\mathrm{Thr}^{80} \rightarrow\right.$ Asn) expressed on the $\alpha 1$ helix region by B6 and bm19 mutant strains, respectively, bm19 mutant $\left(\mathrm{K}^{\mathrm{bm} 19} ; \mathrm{Ass}^{80}\right)$ splenocytes were stimulated weekly with irradiated B6 $\left(\mathrm{K}^{\mathrm{b}} ; \mathrm{Thr}^{80}\right)$ splenocytes for a period of seven weeks. As shown in Figure 1, bm19 anti-B6 CTL effectors display strong $\mathrm{H}-2 \mathrm{~K}^{\mathrm{b}}$-specific alloreactivity when tested at week 1 (Fig 1A), 5 (Fig 1B) and 7 (Fig 1C) after weekly stimulation.

In vitro expansion of bm19 anti-B6 CTL effectors occurs among five TCR $V_{\beta}$ families.

To determine whether bm19 anti-B6 CTLs exhibit preferential expansion of distinct $\mathrm{CD} 8^{+} \mathrm{V}_{\beta}$ families under short- and long-term culture conditions, effector cells were stained with 14 FITC-conjugated $\mathrm{V}_{\beta}$-specific $\mathrm{mAbs}$ and counter-stained with a PEconjugated anti-CD8 $\alpha \mathrm{mAb}$ and analyzed by flow cytometry. As shown in Figure 2, five $\mathrm{CD} 8^{+} \mathrm{V}_{\beta}$ families $-\mathrm{V}_{\beta} 8.1 / 8.2,9,10,12$ and 14 - are significantly expanded when compared to naïve bm19 spleen cells. CTL effectors from the $1^{\circ}$ bm19 anti-B6 MLC display preferential expansion of $\mathrm{V}_{\beta} 8.1 / 8.2$ and $\mathrm{V}_{\beta} 12$ families, but $3^{\circ} \mathrm{bm} 19$ anti-B6 CTLs 
show increased expression of the $\mathrm{V}_{\beta} 8.1 / 8.2, \mathrm{~V}_{\beta} 9$ and $\mathrm{V}_{\beta} 12$. Interestingly, only the $\mathrm{V}_{\beta} 8.1 / 8.2$ and $\mathrm{V}_{\beta} 9$ families are preferentially expanded in $5^{\circ}$ bm19 anti-B6 MLCs. All five $C D 8^{+} V_{\beta}$ families - 8.1/8.2, 9, 10, 12 and 14 - are preferentially expressed in $7^{\circ} \mathrm{bm} 19$ anti-B6 MLC (Figure 2). The percentage of $\mathrm{V}_{\beta}{ }^{+}$cells for any given family of $\mathrm{CD} 8^{+} \mathrm{V}_{\beta}$ alloreactive CTLs is defined as follows: $100 \mathrm{X}\left(\mathrm{V}_{\beta} \mathrm{n}\right.$ value/sum of $\mathrm{V}_{\beta}$ values $)(49)$. These findings indicate that multiple bm19 anti-B6 $\mathrm{CD}^{+} \mathrm{TCR} \mathrm{V}_{\beta}$ families underwent preferential expansion during short- and long-term culture conditions and may be involved in the $\mathrm{K}^{\mathrm{b}}$-specific bm19 alloreactive CTL response.

Depletion of $V_{\beta} 8, V_{\beta} 10, V_{\beta} 14$ or $V_{\beta} 17$ families from naïve bm19 splenic $T$ cells yield fully alloreactive $3^{\circ}$ bm 19 anti-B6 CTL effectors.

To determine the lytic activity of different bm19 anti-B6 TCR $\mathrm{V}_{\beta}$ populations, naïve bm19 spleen cells were first separated into $\mathrm{V}_{\beta}$-depleted and $\mathrm{V}_{\beta}$-enriched fractions by indirect panning in vitro on mAb-coated petri dishes, using one of the $\mathrm{V}_{\beta}$-specific mAbs described above. $C D 8^{+} \mathrm{T}$ cells from each $\mathrm{V}_{\beta}$ family were then stimulated in MLCs with irradiated B6 spleen cells, as previously described. As shown in Figure 3, the selective removal or depletion of $\mathrm{V}_{\beta} 8.1 / 8.2, \mathrm{~V}_{\beta} 14$ or $\mathrm{V}_{\beta} 17 \mathrm{bm} 19 \mathrm{CD} 8^{+} \mathrm{T}$ cells has no discernible effect on the lytic response of $3^{\circ}$ bm19 anti-B6 CTLs against the allogeneic target, S.B6. Enrichment for $\mathrm{V}_{\beta} 8^{+}, \mathrm{V}_{\beta} 14^{+}$or $\mathrm{V}_{\beta} 17^{+}$bm19 $\mathrm{CD} 8^{+} \mathrm{T}$ cells, however, results in a dramatic reduction in the alloreactive response to S.B6 target cells. Thus, although the bm19 $\mathrm{V}_{\beta} 8^{+}$and $\mathrm{V}_{\beta} 14^{+} \mathrm{CTLs}$ are expanded during short- and long-term bm19 anti-B6 MLCs, they do not contribute to the alloreactive response against S.B6 target cells. 
In these experiments, we relied on the $V_{\beta} 17$ family as a suitable negative control, since $\mathrm{CD} 8^{+} \mathrm{T}$ cells of this $\mathrm{V}_{\beta}$ family are not expanded in $1^{\circ}, 3^{\circ}, 5^{\circ}$ or $7^{\circ}$ bm19 anti-B6 MLCs (data not shown). Results for the $\mathrm{V}_{\beta} 10$ depletion and enrichment are not shown here since this population of potential bm19 anti-B6 CTLs does not undergo statistically significant expansion until the seventh week of restimulation (Figure 2).

We compared the percentage of unpanned $3^{\circ} \mathrm{bm} 19$ anti-B6 CTL effectors to that of $V_{\beta}$-depleted and $V_{\beta}$-enriched $3^{\circ}$ bm19 anti-B6 $C D 8^{+} T$ cells from the $V_{\beta} 8.1 / 8.2, V_{\beta} 10$, $V_{\beta} 14$ or $V_{\beta} 17$ families to determine the extent of their expansion following $m A b$-specific panning. As shown in Table I, $3^{\circ}$ bm19 anti-B6 CTL effectors consist of $19.4 \%$ $\mathrm{V}_{\beta} 8.1 / 8.2^{+} \mathrm{T}$ cells in the absence of direct panning, while $\mathrm{mAb}$-specific depletion reduces this population 5-fold (3.7\%). The depletion of $\mathrm{CD} 8^{+} \mathrm{V}_{\beta} 8.1 / 8.2^{+}$cells also substantially reduces the lytic capacity to approximately $9 \mathrm{LU}$, compared to $\sim 20 \mathrm{LU}$ in unpanned $3^{\circ}$ bm19 anti-B6 MLCs (Table I, column D). Enrichment for $\mathrm{V}_{\beta} 8.1 / 8.2$ CTLs increases this population approximately 4 -fold (77.8\%) over that of unpanned $3^{\circ} \mathrm{bm} 19$ anti-B6 CTLs. Although the percentage of $\mathrm{CD} 8^{+} \mathrm{V}_{\beta} 8.1 / 8.2^{+} \mathrm{T}$ cells is increased significantly, its lytic capacity is dramatically reduced compared to that of unpanned $3^{\circ}$ bm19 anti-B6 MLCs (approximately $0 \mathrm{LU}$ versus $\sim 20 \mathrm{LU}$ ).

Also shown in Table $\mathrm{I}$, depletion by panning with the $\mathrm{V}_{\beta} 10$-specific $\mathrm{mAb}$ reduces the $\mathrm{CD} 8^{+} \mathrm{V}_{\beta} 10^{+}$population 5 -fold (1.4\%), compared to approximately $8 \%$ for unpanned CD8 ${ }^{+}$TCR $V_{\beta} 10^{+} \mathrm{T}$ cells in the $3^{\circ}$ bm19 anti-B6 MLC. This $\mathrm{V}_{\beta} 10$ depletion substantially reduces the lytic capacity to $\sim 6 \mathrm{LU}$, compared to $\sim 20 \mathrm{LU}$ in the unpanned $3^{\circ}$ bm19 anti-B6 MLCs. Enrichment for $\mathrm{V}_{\beta} 10^{+} \mathrm{CTLs}$ increases the $\mathrm{CD} 8^{+} \mathrm{V}_{\beta} 10^{+}$population approximately 11-fold (92.3\%) over unpanned $3^{\circ}$ bm19 anti-B6 MLCs. Following 
enrichment for $\mathrm{V}_{\beta} 10^{+} \mathrm{CTLs}$, however, the lytic capacity of $\mathrm{CD} 8^{+} \mathrm{V}_{\beta} 10^{+}$-enriched CTLs is reduced to $\sim 5 \mathrm{LU}$, compared to $\sim 20 \mathrm{LU}$ in unpanned $3^{\circ} \mathrm{bm} 19$ anti-B6 MLCs.

In the absence of panning, $3^{\circ} \mathrm{bm} 19$ anti-B6 MLC effectors consists of $3.7 \% \mathrm{CD} 8^{+}$ $\mathrm{V}_{\beta} 14^{+} \mathrm{T}$ cells (Table I), while depletion of $\mathrm{CD} 8^{+} \mathrm{TCR} \mathrm{V}_{\beta} 14^{+} \mathrm{T}$ cells by $\mathrm{mAb}$-specific panning only reduces the $\mathrm{CD} 8^{+} \mathrm{V}_{\beta} 14^{+}$population 1.5 -fold (2.4\%). The lytic capacity of $\mathrm{CD} 8^{+} \mathrm{V}_{\beta} 14^{+}$cells is moderately reduced ( $\left.\sim \mathrm{LU}\right)$ when compared to unpanned $3^{\circ}$ bm19 anti-B6 MLCs ( $20 \mathrm{LU})$. Enrichment for $\mathrm{V}_{\beta} 14$ cells dramatically increases the $\mathrm{CD} 8^{+}$ $\mathrm{V}_{\beta} 14^{+}$population 22-fold (83.6\%) over unpanned $3^{\circ} \mathrm{bm} 19$ anti-B6 MLCs and yet the alloreactive response for $\mathrm{H}-2 \mathrm{~K}^{\mathrm{b}}$ target cells is negligible (with a $\mathrm{LU}$ of $\sim 0$ ) compared to that of unpanned $3^{\circ} \mathrm{bm} 19$ anti-B6 MLCs $(\sim 20 \mathrm{LU})$. Collectively, these results indicate that although there is a preferential expansion of the $C D 8^{+} \mathrm{V}_{\beta} 8.1 / 8.2, \mathrm{~V}_{\beta} 10$, and $\mathrm{V}_{\beta} 14$ families in vitro, these $\mathrm{V}_{\beta}$ families are not involved in the $3^{\circ} \mathrm{bm} 19$ anti-B6 alloreactive response to $\mathrm{H}-2 \mathrm{~K}^{\mathrm{b}}$ target cells.

$T C R V_{\beta} 9$ and $V_{\beta} 12$ family depletion of naïve bm 19 spleen cells abrogates the alloreactive response of $3^{\circ}$ bm19 anti-B6 CTLs.

We also determined the lytic capacity of $3^{\circ}$ bm19 anti-B6 MLCs either depleted or enriched for TCR $V_{\beta} 9$ and $V_{\beta} 12$ families (Figure $4 A$ and $4 B$ ). The selective removal of $\mathrm{V}_{\beta} 9$ or $\mathrm{V}_{\beta} 12$ families reduces the alloreactive responsiveness of $3^{\circ} \mathrm{bm} 19$ anti-B6 effectors. However, after enriching for $V_{\beta} 9$ or $V_{\beta} 12$ families the lytic capacity of these $3^{\circ}$ bm19 anti-B6 CTLs is comparable ( $\sim 20 \mathrm{LU}$ and $\sim 15 \mathrm{LU}$, respectively), compared to unpanned $3^{\circ}$ bm19 anti-B6 MLC controls ( 20 LU) (Table II). To determine the effect of depleting multiple $V_{\beta}$ families on the alloreactivity of $3^{\circ}$ bm19 anti-B6 effectors, both 
$\mathrm{V}_{\beta} 9$ and $\mathrm{V}_{\beta} 12$ families $\left(\mathrm{V}_{\beta} 9 / 12\right)$ were removed by $\mathrm{mAb}$-specific panning and their lytic capacity was determined. As shown in Figure $4 \mathrm{C}, \mathrm{V}_{\beta} 9 / 12$ depletion completely abrogates the alloreactive CTL response, in a $4 \mathrm{~h}{ }^{51} \mathrm{Cr}$-release assay, and $\mathrm{V}_{\beta} 9 / 12$ enrichment enhances the lytic capacity of $3^{\circ} \mathrm{bm} 19$ anti-B6 CTLs ( 100 LU versus $\left.\sim 20\right)$ for the allogeneic target, S.B6. These findings demonstrate that both $\mathrm{V}_{\beta} 9^{+}$and $\mathrm{V}_{\beta} 12^{+}$ CTLs contribute synergistically to the alloreactive response of bm19 anti-B6 CD8 ${ }^{+}$ effectors for S.B6 targets.

To determine the relative contributions of $\mathrm{V}_{\beta} 9$ and $\mathrm{V}_{\beta} 12$ families to the bm19 anti-B6 alloreactive CTL response, we analyzed TCR $V_{\beta} 9-, V_{\beta} 12$ - and $V_{\beta} 9 / 12$-depleted and -enriched $3^{\circ}$ bm 19 anti-B6 cultures by two-color flow cytometry. As shown in Table II, $3^{\circ}$ bm19 anti-B6 $\mathrm{CD}^{+}$effectors contain approximately $7.2 \% \mathrm{~V}_{\beta} 9^{+}$cells before panning, but after $\mathrm{V}_{\beta} 9$-specific depletion this population is reduced six-fold (1.2\%). This depletion of $\mathrm{V}_{\beta} 9^{+}$CTLs substantially reduces the lytic capacity of $\mathrm{V}_{\beta} 9^{-} \mathrm{CD} 8^{+}$cells to $\sim 2$ $\mathrm{LU}$, compared to $\sim 20 \mathrm{LU}$ in unpanned $3^{\circ}$ bm19 anti-B6 MLCs. By enriching for $\mathrm{V}_{\beta} 9$ expressing $\mathrm{T}$ cells, the $\mathrm{CD} 8^{+} \mathrm{V}_{\beta} 9^{+}$population is increased 11 -fold (85.1\%) over unpanned $3^{\circ}$ bm19 anti-B6 MLCs. Although the percentage of the $\mathrm{CD} 8^{+}, \mathrm{TCR} \mathrm{V}_{\beta} 9^{+}$population is increased significantly by indirect panning, its lytic capacity is comparable to that of unpanned $3^{\circ}$ bm19 anti-B6 cultures ( $\sim 20 \mathrm{LU}$ versus $\left.\sim 20 \mathrm{LU}\right)$. Thus, although $3^{\circ}$ bm19 anti-B6 $\mathrm{CD} 8^{+} \mathrm{V}_{\beta} 9^{+} \mathrm{T}$ cells contribute to bm19 anti-B6 alloreactivity, they are most likely not the only $\mathrm{V}_{\beta}{ }^{+}$CTLs involved.

$\mathrm{CD}^{+} \mathrm{T}$ cells from the $\mathrm{V}_{\beta} 12$ family constitute approximately $6.4 \%$ of unpanned $3^{\circ}$ bm19 anti-B6 CTLs (Table II). Depletion and enrichment for $\mathrm{V}_{\beta} 12^{+} \mathrm{T}$ cells by panning 
results in a 4 -fold decrease (3.4\%) and a 4 -fold increase (78\%), respectively, in the $\mathrm{CD} 8^{+}$ $\mathrm{V}_{\beta} 12^{+}$population, compared to unpanned $3^{\circ} \mathrm{bm} 19$ anti-B6 CTLs (16.5\%). The selective removal of $\mathrm{CD}^{+} \mathrm{V}_{\beta} 12^{+} \mathrm{T}$ cells causes a $74 \%$ reduction $(\sim 7 \mathrm{LU}$ versus $\sim 20 \mathrm{LU})$ in the lytic capacity of $3^{\circ}$ bm19 anti-B6 effectors, which mirrors the decrease in $\mathrm{V}_{\beta} 12^{+}$CTLs following depletion by panning. In addition, a 4-fold enrichment of $\mathrm{CD}^{+} \mathrm{V}_{\beta} 12^{+}$cells not only fails to enhance the lytic capacity of $3^{\circ}$ bm19 anti-B6 effectors, it reduces the LU value ( $\sim 15 \mathrm{LU}$ versus $\sim 20 \mathrm{LU})$. These findings indicate that $3^{\circ} \mathrm{bm} 19$ anti-B6 CD8 ${ }^{+}$ TCR $\mathrm{V}_{\beta} 12^{+}$population contributed to B6-specific allorecognition, as demonstrated by the reduction in lytic capacity following TCR $\mathrm{V}_{\beta} 12^{+}$depletion, but presumably require additional CTLs from other $\mathrm{V}_{\beta}$ families for maximum lytic activity.

Taken together, the data indicate that both $\mathrm{V}_{\beta} 9^{+}$and $\mathrm{V}_{\beta} 12^{+}$bm19 CTLs are necessary to achieve optimal $\mathrm{K}^{\mathrm{b}}$-specific alloreactivity in vitro. Furthermore, under these conditions other $\mathrm{CD}^{+} \mathrm{V}_{\beta}$ families are not involved in mediating this alloreactivity. To confirm this conclusion, we examined $V_{\beta} 9 / 12$-enriched and -depleted CTLs for their alloreactivity against B6. Panning to remove both $\mathrm{V}_{\beta} 9$ and $\mathrm{V}_{\beta} 12$ (Table II) reduces the $\mathrm{CD}^{+} \mathrm{V}_{\beta} 9 / 12^{+}$fraction from $23.1 \%$ in unpanned $3^{\circ} \mathrm{bm} 19$ anti-B6 MLC to approximately $1.7 \%$ and completely abrogates the alloreactivity of $3^{\circ} \mathrm{bm} 19$ anti-B6 CTLs. Conversely, enrichment for $\mathrm{CD}^{+} \mathrm{V}_{\beta} 9 / 12^{+}$CTLs results in a 3.5 -fold (85.8\%) increase in the percentage of $\mathrm{CD}^{+} \mathrm{V}_{\beta} 9 / 12^{+} \mathrm{CTLs}$ compared to unpanned $3^{\circ} \mathrm{bm} 19$ anti-B6 MLC CD8 ${ }^{+}$ $\mathrm{V}_{\beta} 9 / 12^{+} \mathrm{T}$ cells $(23.1 \%)$. The lytic capacity of TCR $\mathrm{V}_{\beta} 9 / 12^{+}$-enriched CTLs from the $3^{\circ}$ bm19 anti-B6 MLC is enhanced approximately 5-fold ( 100 LU) compared to that of unpanned cultures. Thus, these results confirm that the selective removal of both $\mathrm{V}_{\beta} 9^{+}$ 
and $\mathrm{V}_{\beta} 12^{+}$families from the $3^{\circ}$ bm19 anti-B6 MLCs completely abrogates the B6directed alloreactivity of $3^{\circ} \mathrm{bm} 19$ anti-B6 CTLs.

Antigen-specific and unrelated allospecific proliferation and function remain intact following the selective removal of TCR $V_{\beta} 9 / 12^{+} C D 8^{+}$T cells.

Having shown that $\mathrm{V}_{\beta} 9 / 12^{+} \mathrm{T}$ cell depletion from $3^{\circ}$ bm19 anti-B6 cultures completely remove $\mathrm{K}^{\mathrm{b}}$-specific in vitro alloreactivity, it is equally important that the remaining $\mathrm{CD}^{+} \mathrm{T}$ cells are undiminished in their functional capacity to recognize and respond to antigens unrelated to the $\mathrm{H}-2 \mathrm{~K}^{\mathrm{b}}$ alloantigen. To address this concern, we selectively removed $\mathrm{CD}^{+} \mathrm{V}_{\beta} 9 / 12^{+} \mathrm{T}$ cells from naïve bm19 spleens by panning and stimulated the remaining $\mathrm{CD}^{+} \mathrm{V}_{\beta} 9 / 12^{-} \mathrm{T}$ cells with either irradiated BALB/c splenocytes (unrelated alloantigen) or irradiated bm19 splenocytes pulsed with VSV-8 peptide (foreign peptide) or the MI B chain p7-15 (self-peptide). The proliferative capacity of $\mathrm{V}_{\beta} 9 / 12^{-} 1^{\circ}$ bm19 anti-BALB/c, bm19 anti-VSV-8, and bm19 anti-MI B chain p7-15 CTLs was determined on day four by measuring the 18 -h incorporation of $2 \mu \mathrm{Ci}{ }^{3} \mathrm{H}-\mathrm{TdR}$. As shown in Figure 5A, the selective removal of $\mathrm{CD}^{+} \mathrm{V}_{\beta} 9 / 12 \mathrm{~T}$ cells does not interfere with alloreactive or antigen-specific proliferation.

To assess the alloreactive cytolytic activity of $\mathrm{V}_{\beta} 9 / 12$-depleted bm19 spleen cells stimulated with the unrelated $\mathrm{H}-2^{\mathrm{d}}$ alloantigen, we compared the in vitro functional reactivity of $\mathrm{V}_{\beta} 9 / 12^{-}$and normal $1^{\circ}$ bm19 anti-BALB/c CTLs by ${ }^{51} \mathrm{Cr}$-release assay. As shown in Figure 5B, $\mathrm{V}_{\beta} 9 / 12^{-} 1^{\circ}$ bm19 anti-BALB/c CTLs lyse P815 (H-2 $\left.{ }^{\mathrm{d}}\right)$, but not EL-4 $\left(\mathrm{H}-2^{b}\right)$, target cells as efficiently as the normal bm19 anti-BALB/c CTLs. This confirms that the cytolytic activity against unrelated $\mathrm{H}-2^{\mathrm{d}}$ alloantigen is unaffected by removing 
$\mathrm{V}_{\beta} 9 / 12^{+} \mathrm{T}$ cells from bm19 anti-B6 MLCs. We also examine whether the antigenspecific cytolytic response of bm19 spleen cells depleted of $\mathrm{V}_{\beta} 9 / 12^{+} \mathrm{T}$ cells for the viral peptide, VSV-8, or the MI B chain p7-15 self-peptide is altered. Target cells expressing $\mathrm{K}^{\mathrm{bm} 19}$ were labeled with ${ }^{51} \mathrm{Cr}$ and pulsed with $2 \mu \mathrm{M}$ VSV-8, MI B chain $\mathrm{p} 7-15$ or media alone and were incubated for $4 \mathrm{~h}$ with $\mathrm{V}_{\beta} 9 / 12^{-}$or normal $1^{\circ}$ bm19 anti-VSV-8 or bm19 anti-MI B chain p7-15 CTLs. As shown in Figure 5C, $\mathrm{V}_{\beta} 9 / 12^{-} 1^{\circ}$ bm19 anti-VSV-8 CTLs respond as efficiently as normal bm19 anti-VSV CTLs to VSV-8 in a $\mathrm{K}^{\mathrm{bm} 19}$ restricted manner. This is also the case for the $\mathrm{V}_{\beta} 9 / 12^{-} 1^{\mathrm{o}}$ bm19 anti-MI $\mathrm{B}$ chain $\mathrm{p} 7-15$ response, as shown in Figure 5D. Thus, these findings confirm that under these in vitro conditions, the $\mathrm{V}_{\beta} 9 / 12^{-} \mathrm{CD} 8^{+} \mathrm{T}$ cells are unimpaired in their capacity to respond efficiently to other foreign antigens. 


\section{DISCUSSION}

Despite continuing advances and refinements in immunosuppressive drug therapies, the inherent $\mathrm{T}$ cell inhibitory properties of these treatment modalities predispose the transplant recipient to an increased risk for various infections $(56,57)$. In

a study by Walker and coworkers (2) it was noted that, depending upon the extent of immunosuppressive treatment, $52-86 \%$ of renal transplant patients experienced one or more episodes of infection during the first 6 months post transplantation. Approximately 65 percent of renal transplant patients develop infection during the first 6 months post transplantation, leading to death in 3.8 percent of those individuals (1).

Transplant recipients are also predisposed to higher rates of malignancy compared to the general population (56). Vital organ transplants, such as cardiac, liver and lung allografts, require intense immunosuppression and have a higher incidence of malignancies compared to renal allograft recipients $(3,4,58)$. The most common types of cancer noted after organ transplantation include skin carcinomas (particularly squamouscell, basal-cell, Kaposi's sarcoma and melanoma), but the occurrence of lymphomas, meningiomas, bronchogenic carcinomas and carcinomas of the breast, esophagus, colon and cervix have also been demonstrated $(2,59)$.

To alleviate these immunosuppression-associated problems in transplant patients, a number of investigators (18 - 20) have sought to distinguish transplant-specific, alloreactive $\mathrm{T}$ cells in the $\mathrm{T}$ cell repertoire. In so doing, it may be possible to devise a feasible approach to selectively eliminate these $\mathrm{T}$ cells, without disturbing the intricate balance of antigen-specific $\mathrm{T}$ cell reactivity required for controlling the immune response to various pathogens and tumors. In this study we address the in vitro requirements for 
identifying and eliminating allograft-specific CTLs without compromising the in vitro CTL response to other foreign antigens.

As noted in the introduction, a recent study by Grandea and Bevan (24) involving the $\mathrm{MHC}$ class I $\mathrm{H}-2 \mathrm{~K}^{\mathrm{b}}$ transgenic mouse mutant, $\mathrm{H}-2 \mathrm{~K}^{\mathrm{b}, \mathrm{E} 65}$, demonstrate that activation of an alloreactive CTL response can be initiated by as little as a single amino acid disparity in the $\mathrm{H}-2 \mathrm{~K}^{\mathrm{b}}$ molecule. The transgenic mouse mutant, $\mathrm{H}-2 \mathrm{~K}^{\mathrm{b}, \mathrm{E} 65}$, has a single $\mathrm{H}-2 \mathrm{~K}^{\mathrm{b}}$ amino acid substitution at position $65\left(\mathrm{Gln}^{65} \rightarrow \mathrm{Glu}\right)$, located on the outward face of the $\alpha$-helix of the $\alpha 1$ domain and interacts with the TCR but does not affect the peptide-binding groove. This study supports the earlier finding by Bevan and Hunig (60) that distinct allogeneic differences, involving only a few amino acid changes in the class I MHC molecule, elicite a stronger alloreactivity than those that are more disparate. Their work also suggests that alloreactive CTLs may have higher TCR avidities for nonconservative amino acid changes within a closely related class I MHC-peptide complex (24).

The bm19 mutant mouse strain, the model used in the current study, differs by a single amino acid change at position $80\left(\mathrm{Thr}^{80} \rightarrow\right.$ Asn) in the $\mathrm{H}-2 \mathrm{~K}^{\mathrm{b}}$ molecule of the $\mathrm{B} 6$ parental strain (25). It is unclear whether the basis for the bm19 anti-B6 alloreactive CTL response is due to direct or indirect allorecognition, or both. But in either case, we clearly demonstrate that CTLs from both the $V_{\beta} 9$ and $V_{\beta} 12$ TCR families are key participants in the immune effector response. Interestingly, it is possible that one of these TCR $V_{\beta}$ families $\left(V_{\beta} 9\right.$ or $\left.V_{\beta} 12\right)$ recognizes the distinct amino acid change $\left(\mathrm{Thr}^{80}\right)$ on the $\alpha$-helix, via direct allorecognition, while the second TCR $V_{\beta}$ family may respond through indirect allorecognition, reacting to a change in $\mathrm{MHC} /$ peptide three-dimensional 
structure, due to either: (1) the altered binding configuration of a self-peptide that differs between $\mathrm{K}^{\mathrm{b}}$ and $\mathrm{K}^{\mathrm{bm} 19}$, or (2) a $\mathrm{K}^{\mathrm{bm} 19}$-bound peptide derived from the allogeneic $\mathrm{H}-2 \mathrm{~K}^{\mathrm{b}}$ molecule.

Studies are presently being planned to determine whether one or both of the bm19 anti-B6 $V_{\beta} 9$ and $V_{\beta} 12$ families, identified as alloreactive CTL effectors in this paper, might utilize indirect recognition to respond to allogeneic $\mathrm{K}^{\mathrm{b}}$ differences. In these studies, peptides from $\mathrm{H}-2 \mathrm{~K}^{\mathrm{bm} 19}$ molecules stimulated with $\mathrm{B} 6$ spleen cells will be eluted from the $\mathrm{H}-2 \mathrm{~K}^{\mathrm{bm} 19} /$ peptide complex and sequenced by reverse-phase HPLC and tandem mass spectrometry to determine peptide composition. This process has been documented in the identification of peptides associated with human bladder tumor cell lines (61), insulin-dependent diabetes mellitus (62) and GVHD in allogeneic bone marrow transplantation in mice (63). The peptide sequence analysis will be used to determine whether the $\mathrm{K}^{\mathrm{bm} 19}$-bound peptide contains the native $\mathrm{Thr}^{80}$ residue found in the wild-type $\mathrm{K}^{\mathrm{b}}$ sequence. If so, subsequent in vitro $\mathrm{CTL}$ analysis, using peptide-pulsed $\mathrm{H}-2 \mathrm{~K}^{\mathrm{bm} 19}$ expressing target cells, will be performed to evaluate the cytolytic responsiveness of alloreactive $\mathrm{V}_{\beta} 9^{+}$and $\mathrm{V}_{\beta} 12^{+}$CTLs. In addition to traditional CTL analysis with these peptide-pulsed target cells, MHC/peptide tetramers $(64,65)$ will be employed to determine whether CTLs of either or both $V_{\beta} 9$ and $V_{\beta} 12$ families respond via indirect allorecognition; and, if so, what proportion of these CTLs respond accordingly. One advantage to using $\mathrm{K}^{\mathrm{bm} 19}$ /peptide tetramers is that the three-dimensional structure can be discerned with the aid of X-ray crystal structure analysis and computer-generated modeling approaches. In this case, the orientation and interaction of CTLs from a given 
$\mathrm{V}_{\beta}$ family $\left(\mathrm{V}_{\beta} 9\right.$ or $\left.\mathrm{V}_{\beta} 12\right)$ with the $\mathrm{K}^{\mathrm{bm} 19} /$ peptide complex could also be examined in greater detail.

As previously noted, Connolly and co-workers implicate TCR $\mathrm{V}_{\beta} 8^{+}$CTLs in the $\mathrm{L}^{\mathrm{d}}$-specific response of the $\mathrm{L}^{\mathrm{d}}$-loss mutant $\mathrm{dm} 2$ when stimulated with irradiated wild-type BALB/c spleen cells. Removal of $\mathrm{V}_{\beta} 8^{+} \mathrm{CTLs}$, using the anti- $\mathrm{V}_{\beta} 8$ monoclonal antibody, F23.1, diminishes the $\mathrm{H}-2 \mathrm{~L}^{\mathrm{d}}$-specific CTL response by approximately $80 \%$ (27). Although in vivo depletion of $\mathrm{V}_{\beta} 8^{+} \mathrm{T}$ cells prolongs the mean survival of $\mathrm{L}^{\mathrm{d}}$-disparate skin grafts by two-fold it has no effect on rejection of $\mathrm{H}-2 \mathrm{D}^{\mathrm{k}}$-disparate skin grafts $(27,66)$; thus indicating the allospecific effect of $\mathrm{V}_{\beta} 8^{+} \mathrm{T}$ cell depletion on allograft rejection.

In the current study, we show that two distinct $\mathrm{V}_{\beta}$ families work synergistically in the in vitro alloreactive response of bm19 anti-B6 CTL effectors. In a companion paper (Frankenberry et al., submitted) we extend these studies to examine the effect of in vivo $\mathrm{V}_{\beta} 9 / 12^{+} \mathrm{T}$ cell depletion in bm19 mice on their ability to reject B6 skin allografts. Furthermore, we compare these $\mathrm{V}_{\beta} 9 / 12^{+} \mathrm{T}$ cell-depleted bm19 mice with normal bm19 mice in their ability to mount an antigen-specific response leading to the clearance of a Listeria monocytogenes infection.

In summary, we identify $\mathrm{CD}^{+} \mathrm{T}$ cells from both $\mathrm{V}_{\beta} 9$ and $\mathrm{V}_{\beta} 12$ families as the critical alloreactive CTL effectors in the in vitro response of long- and short-term bm19 anti-B6 CTLs against allogeneic $\mathrm{K}^{\mathrm{b}}$-expressing targets. Furthermore, depletion of both CTL $V_{\beta}$ families completely abrogates the $\mathrm{K}^{\mathrm{b}}$-directed allospecific response, without inhibiting to other unrelated allogeneic molecules or peptide antigens. This is the first study, to our knowledge, to identify the synergistic effect of multiple $\mathrm{CD}^{+} \mathrm{V}_{\beta}$ families as 
critical effectors in the response against an allogeneic target. In addition, we show that although the $\mathrm{CD}^{+} \mathrm{V}_{\beta}$ families, $\mathrm{V}_{\beta} 8.1 / 8.2,10$ and 14 , underwent significantly expansion upon in vitro stimulation with B6 spleen cells, they are not actively involved in the bm19 anti-B6 alloreactive CTL response. We also show that the selective removal of both TCR $\mathrm{V}_{\beta} 9 / 12$ families abrogates the in vitro response of bm19 anti-B6 effectors toward B6specific target cells, but does not inhibit unrelated allo- or antigen-specific host responses.

The removal of select CTL populations that mediate one specific alloreactive response without compromising unrelated allospecific or antigen-specific responses is a novel and exciting discovery. It suggests a unique approach to confronting the daunting complications of transplant immunology. Rather than broadly depressing the responsiveness of the entire $\mathrm{T}$ cell compartment with non-selective immunosuppressive agents or immunomodulating mAbs, it should be possible to remove only those $\mathrm{T}$ cells with $\mathrm{V}_{\beta}$-specific TCRs that are responsive to the MHC-peptide complexes expressed on the allograft. 


\begin{tabular}{|c|c|c|c|c|}
\hline $\begin{array}{l}\text { Table I } \\
\text { Percent } \mathrm{CD8}^{+} \mathrm{T}\end{array}$ & $\mathrm{V}_{\beta}^{+}$cells an & c unit value & ${ }^{\circ}$ bm19 ant & TLs \\
\hline TCR $V_{\beta}$ family & Naïve bm19 1 & Untreated $^{2}$ & $\mathrm{~V}_{\beta}$-panned ${ }^{3}$ & LU values $^{4}$ \\
\hline $\mathrm{V}_{\beta} 8.1 / 8.2^{+}$ & $10.8 \pm 1.5$ & $19.4 \pm 1.6$ & $77.8 \pm 7.3$ & 0 \\
\hline $\mathrm{V}_{\beta} 8.1 / 8.2^{-}$ & & & $3.7 \pm 2.5$ & $\sim 9$ \\
\hline $\mathrm{V}_{\beta} 10^{+}$ & $4.6 \pm 2.0$ & $8.1 \pm 0.8$ & $92.3 \pm 4.2$ & $\sim 5$ \\
\hline $\mathrm{V}_{\beta} 10^{-}$ & & & $1.4 \pm 0.1$ & $\sim 6$ \\
\hline $\mathrm{V}_{\beta} 14^{+}$ & $7.2 \pm 2.1$ & $3.7 \pm 0.5$ & $83.6 \pm 5.3$ & 0 \\
\hline $\mathrm{V}_{\beta} 14^{-}$ & & & $2.4 \pm 1.5$ & $\sim 8$ \\
\hline $\mathrm{V}_{\beta} 17^{+}$ & $20.4 \pm 3.3$ & $9.0 \pm 4.4$ & $78.7 \pm 3.0$ & 0 \\
\hline $\mathrm{V}_{\beta} 17^{-}$ & & & $6.0 \pm 1.7$ & $\sim 7$ \\
\hline $3^{\circ}$ bm19 anti-B6 & - & - & - & $\sim 20$ \\
\hline $\begin{array}{l}{ }^{1} \text { Percentage } \pm \mathrm{SI} \\
\text { cytometry. } \\
{ }^{2} \text { Percentage } \pm \mathrm{S} \\
{ }^{3} \text { Percentage } \pm \mathrm{S} \\
\mathrm{V}_{\beta} 8.1 / 8.2, \mathrm{~V}_{\beta} 10 \\
{ }^{4} \text { Values are repr } \\
\text { separate experin } \\
\text { Methods. }\end{array}$ & $\begin{array}{l}\mathrm{D} 8^{+} \mathrm{TCR}_{\beta} \\
\mathrm{V}_{\beta} \text { bm19 anti-B } \\
{ }^{\circ} \text { bm19 anti-B } \\
{ }^{3} 14 \text { or } \mathrm{V}_{\beta} 17 \text { o } \\
\text { ntative of the } \\
\text { ts. Calculatio }\end{array}$ & $\begin{array}{l}\text { lies detected } \\
8^{+} \mathrm{TCR} \mathrm{V}_{\beta}^{+} \\
8^{+} \mathrm{TCR} \mathrm{V}_{\beta}^{+} \\
0 . \\
\text { tic capacity } \\
\text { "lytic unit }\end{array}$ & $\begin{array}{l}\text { ve bm19 sp } \\
\text { es in the abs } \\
\text { es following } \\
\text { m19 anti-B } \\
\text { are defined }\end{array}$ & $\begin{array}{l}\text { y flow } \\
\text { f panning. } \\
\text { ng for TCR } \\
\text { of three } \\
\text { terials and }\end{array}$ \\
\hline
\end{tabular}




\section{Table II}

Percent $\mathrm{CD8}^{+} \mathrm{TCR} \mathrm{V}_{\boldsymbol{\beta}}^{+}$cells and lytic unit values for $3^{\circ} \mathrm{bm19}$ anti-B6 CTLs

\begin{tabular}{|c|c|c|c|c|}
\hline TCR $V_{\beta}$ family & Naïve bm19 $19^{1}$ & Untreated $^{2}$ & $\mathrm{~V}_{\beta}$-panned ${ }^{3}$ & LU values ${ }^{4}$ \\
\hline $\begin{array}{l}\mathrm{V}_{\beta} 9^{+} \\
\mathrm{V}_{\beta} 9^{-}\end{array}$ & $5.3 \pm 0.6$ & $7.2 \pm 1.8$ & $\begin{array}{c}85.1 \pm 1.8 \\
1.2 \pm 0.1\end{array}$ & $\begin{array}{l}\sim 20 \\
\sim 2\end{array}$ \\
\hline $\begin{array}{l}\mathrm{V}_{\beta} 12^{+} \\
\mathrm{V}_{\beta} 12^{-}\end{array}$ & $6.4 \pm 0.5$ & $16.5 \pm 2.5$ & $\begin{array}{c}78.2 \pm 7.8 \\
3.4 \pm 2.6\end{array}$ & $\begin{array}{l}\sim 15 \\
\sim 7\end{array}$ \\
\hline $\begin{array}{l}\mathrm{V}_{\beta} 9 / 12^{+} \\
\mathrm{V}_{\beta} 9 / 12^{-}\end{array}$ & $11.7 \pm 0.7$ & $23.1 \pm 1.4$ & $\begin{array}{c}85.8 \pm 0.5 \\
1.7 \pm 0.4\end{array}$ & $\begin{array}{c}\sim 100 \\
0\end{array}$ \\
\hline $3^{\circ} \mathrm{bm} 19$ anti-B6 & - & - & - & $\sim 20$ \\
\hline \multicolumn{5}{|c|}{$\begin{array}{l}{ }^{1} \text { Percentage } \pm \mathrm{SD} \text { naïve } \mathrm{CD} 8^{+} \mathrm{TCR} \mathrm{V}_{\beta}{ }^{+} \text {families detected in naïve bm19 spleens by flow } \\
\text { cytometry. } \\
{ }^{2} \text { Percentage } \pm \mathrm{SD} 3^{\circ} \mathrm{bm} 19 \text { anti-B } 6 \mathrm{CD}^{+} \mathrm{TCR} \mathrm{V}_{\beta}^{+} \text {families in the absence of panning. } \\
{ }^{3} \text { Percentage } \pm \mathrm{SD} 3^{\circ} \mathrm{bm} 19 \text { anti-B } 6 \mathrm{CD} 8^{+} \mathrm{TCR}_{\beta}{ }^{+} \text {families following panning for TCR } \\
\mathrm{V}_{\beta} 9, \mathrm{~V}_{\beta} 12 \text { and } \mathrm{V}_{\beta} 9 / 12 \text { on day } 0 . \\
{ }^{4} \text { Values are representative of the cytolytic capacity of } 3^{\circ} \mathrm{bm} 19 \text { anti-B } 6 \mathrm{MLC} \text { of three } \\
\text { separate experiments. Calculations for "lytic unit values" are defined in Materials and } \\
\text { Methods. }\end{array}$} \\
\hline
\end{tabular}


FIGURES AND FIGURE LEGENDS

Fig. 1 Short- and long-term bm19 anti-B6 MLCs exhibit strong alloreactivity for H-2K $K^{b}$-bearing target cells.

$1^{\circ}(\mathrm{A}), 5^{\circ}(\mathrm{B})$, and $7^{\circ}(\mathrm{C})$ bm19 anti-B6 CTL effectors were incubated with $1 \mathrm{X} 10^{4}{ }^{51} \mathrm{Cr}-$ labeled SP2/0 (•), S.B6 $(\square)$ and S.bm19 ( $\nabla)$ target cells for $4 \mathrm{~h}$ in order to determine their lytic reactivity. Following this incubation, $100 \mu$ samples of supernatants were collected and the number of radioactive counts was determined; cytolytic activity was represented as "percent specific lysis". Spontaneous ${ }^{51} \mathrm{Cr}$ release values from targets in the absence of CTL effectors were $<10 \%$ of maximum in all experiments. The results from a single representative of five separate experiments are shown. 





Fig. 2 In vitro expansion ${ }^{1}$ of bm19 anti-B6 CTL effectors occurs among five $V_{\beta}$ families.

Naïve bm19 spleen cells (solid bars), $1^{\circ}$ (horizontal bars), $3^{\circ}$ (hatched bars) $5^{\circ}$ (open bars), and $7^{\circ}$ (diagonal bars) bm19 anti-B6 CTLs were evaluated for the expression of distinct TCR $V_{\beta}$ families by flow cytometric analysis. Samples of $5 \times 10^{5}$ cells were incubated for 45 min on ice with $20 \mu \mathrm{l}$ (1:100) of one of 14 FITC-conjugated $V_{\beta}$-specific mAbs and counter-stained with $20 \mu \mathrm{l}$ (1:96) of PE-conjugated anti-CD8 $\alpha$ mAb, washed twice with PBS and fixed in $500 \mu \mathrm{l} 1 \%$ formalin. Fixed cells were analyzed by flow cytometry for $C D 8^{+}, V_{\beta}{ }^{+} T$ cell populations and were expressed as $\left(V_{\beta n}\right.$ value/sum of $V_{\beta}$ values) X 100. Asterisks represent statistically significant expansion of bm19 anti-B6 TCR $\mathrm{V}_{\beta}{ }^{+}$families, as compared to naïve spleen cell populations, and were determined by one-way analysis of variance (ANOVA) performed in five separate experiments. ${ }^{1}$ Only those $V_{\beta}$ families that exhibit preferential expansion are shown. 


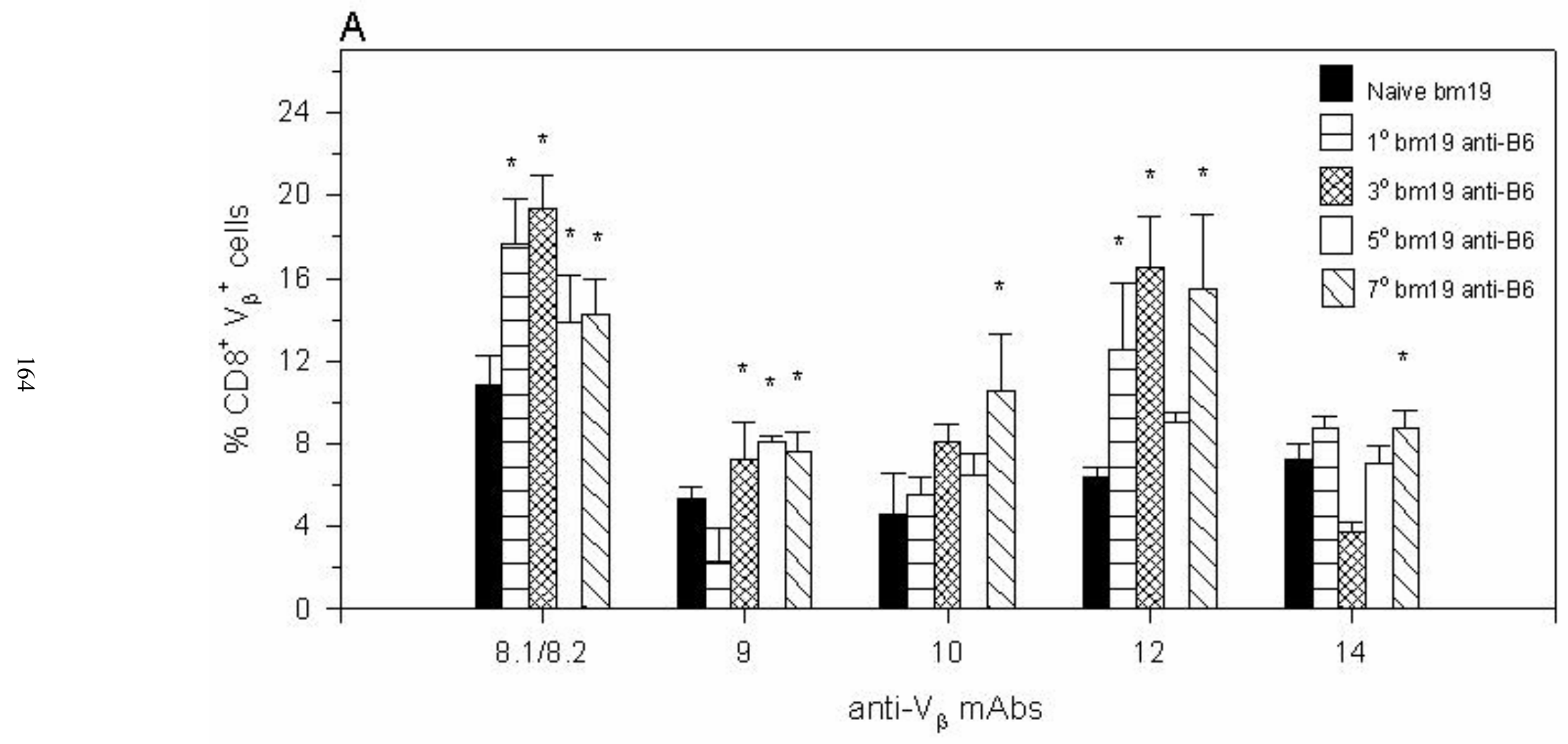


Fig. 3 Depletion of $V_{\beta} 8, V_{\beta} 14$ or $V_{\beta} 17$ families from naïve bm19 splenic $T$ cells yields fully alloreactive $3^{\circ} \mathrm{bm} 19$ anti-B6 CTL effectors.

TCR $\mathrm{V}_{\beta} 8^{+}(\mathrm{A}), \mathrm{V}_{\beta} 14^{+}(\mathrm{B})$, and $\mathrm{V}_{\beta} 17^{+}(\mathrm{C}) \mathrm{T}$ cells from naïve bm19 spleens were depleted and/or enriched by indirect panning, stimulated with irradiated B6 splenocytes and maintained for three wk, as described in the Materials and Methods section. $3^{\circ} \mathrm{bm} 19$ anti-B6 CTL from depleted and/or enriched cultures were incubated with 1 X $10^{4} \mathrm{SP} 2 / 0$ (•), S.B6 ( $\square)$ and S.bm19 $(\nabla){ }^{51}$ Cr-labeled target cells for 4 h. Supernatants $(100 \mu l)$ were collected and cytolytic activity was represented as the "percent specific lysis". Spontaneous release of targets in the absence of CTL effectors was $<10 \%$ of maximum lysis by detergent in all experiments. A single representative of three separate experiments is shown. 

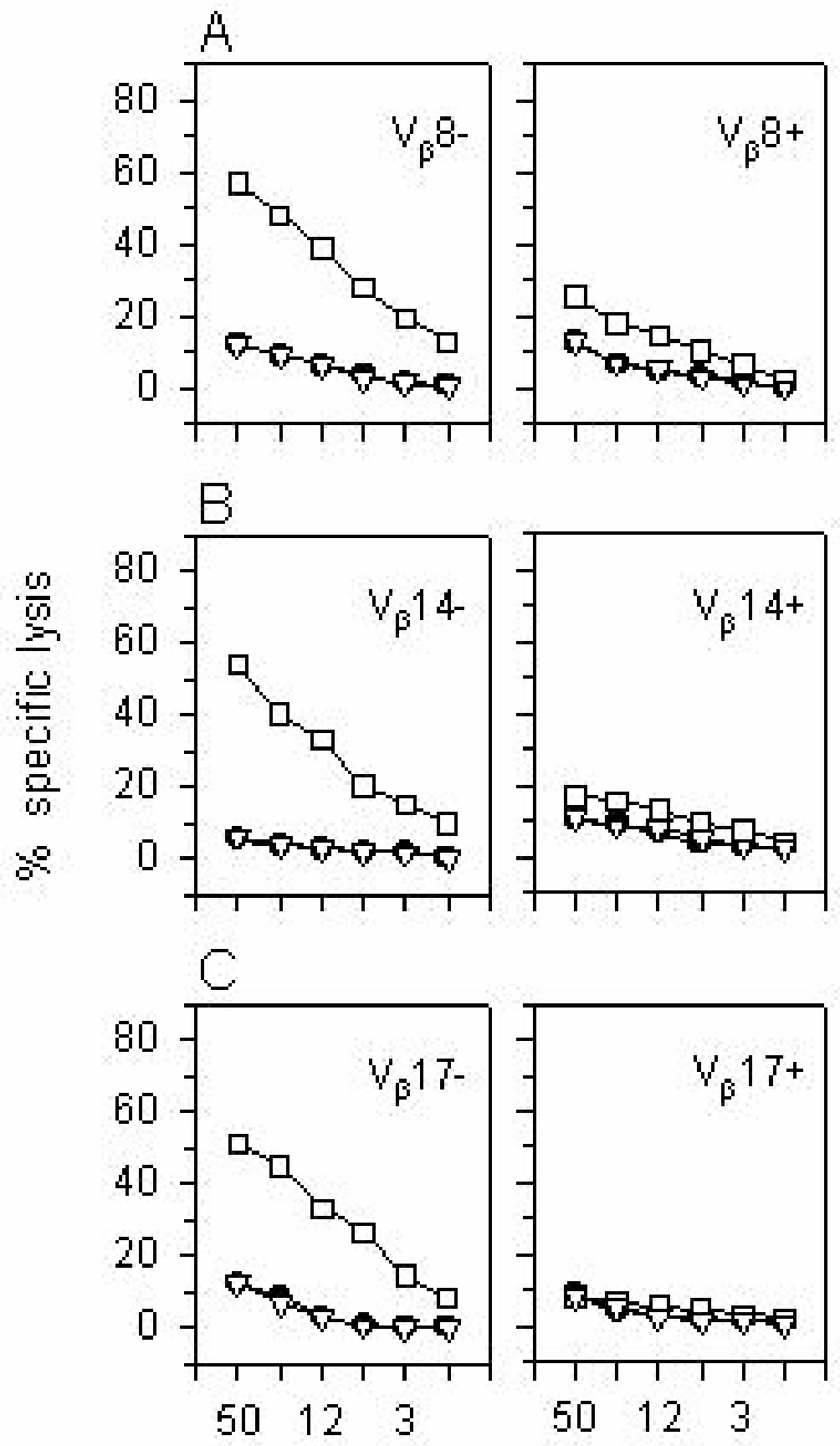

effector-to-target ratio

$-5 \mathrm{~s} 20$
$\square-5.86$
$\nabla \rightarrow \operatorname{s.m} 19$


Fig. 4 TCR $V_{\beta} 9$ and $V_{\beta} 12$ family depletion of naïve bm19 spleen cells abrogates the alloreactive response of $3^{\circ}$ bm19 anti-B6 CTLs.

TCR $\mathrm{V}_{\beta} 9^{+}(\mathrm{A}), \mathrm{V}_{\beta} 12^{+}(\mathrm{B})$, and $\mathrm{V}_{\beta} 9 / 12^{+}$(C) $\mathrm{T}$ cells from naïve bm19 spleens were depleted and/or enriched by indirect panning, stimulated with irradiated B6 splenocytes and maintained for three wk, as described in the Materials and Methods section. $3^{\circ} \mathrm{bm} 19$ anti-B6 CTL from depleted and/or enriched cultures were incubated with 1 X $10^{4} \mathrm{SP} 2 / 0$ (•), S.B6 ( $\square)$ and S.bm19 $(\nabla){ }^{51}$ Cr-labeled target cells for 4 h. Supernatants $(100 \mu l)$ were collected and cytolytic activity was represented as the "percent specific lysis". Spontaneous release of targets in the absence of CTL effectors was $<10 \%$ of maximum lysis by detergent in all experiments. A single representative of three separate experiments is shown. 

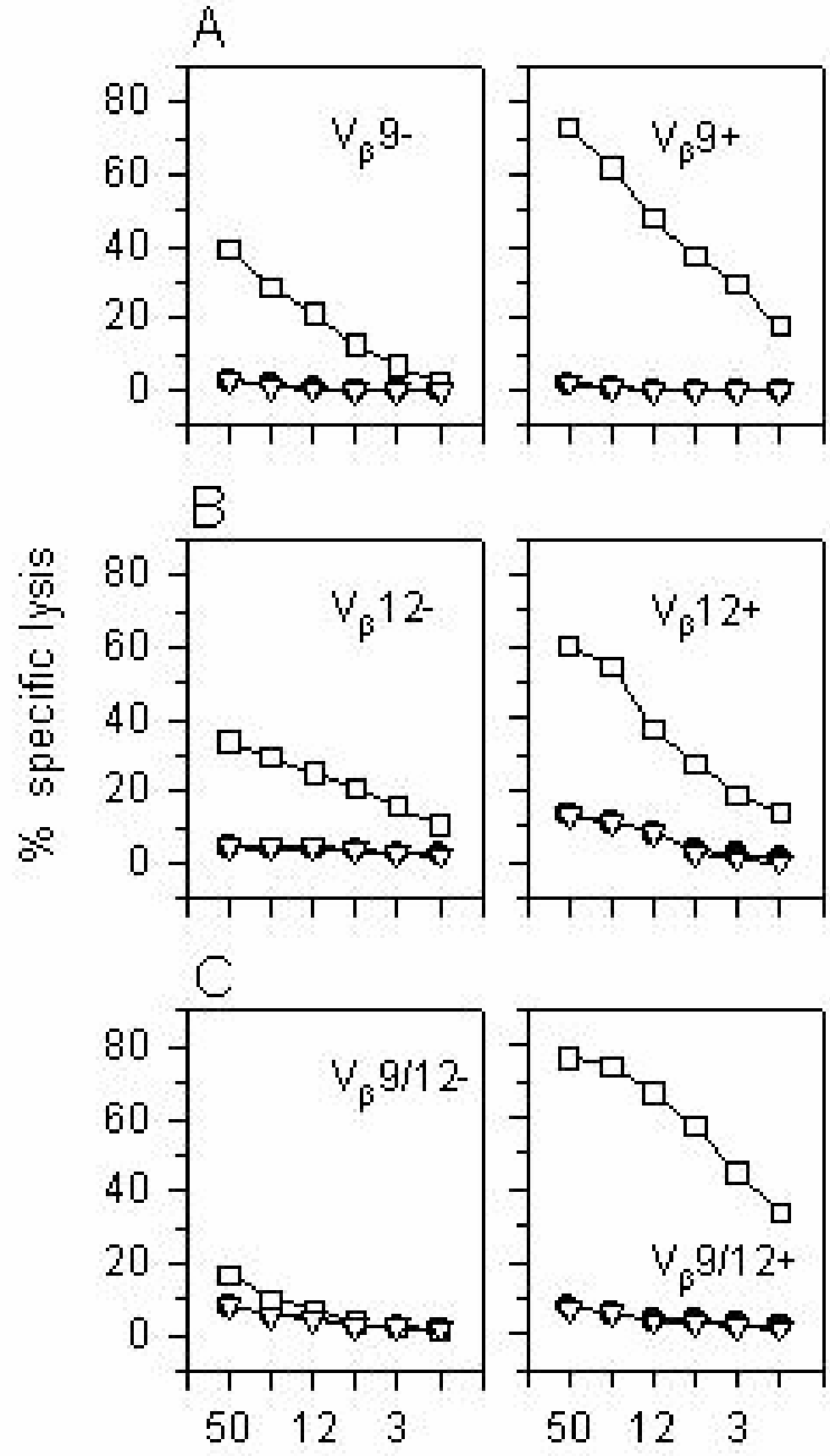

effector-to- target ratio

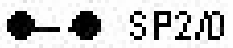

口- 5.66

$\nabla \rightarrow 5.6 m 19$ 
Fig. 5 Antigen-specific and unrelated allospecific proliferation and function remain intact following the selective removal of $T C R \mathrm{~V}_{\beta} 9 / 12^{+} \mathrm{T}$ cells.

A. TCR $\mathrm{V}_{\beta} 9 / 12^{+} \mathrm{T}$ cells from naïve bm19 spleen cells were depleted by indirect panning. The remaining $\mathrm{T}$ cell fractions were stimulated with irradiated BALB/c splenocytes (open bars), irradiated bm19 splenocytes pulsed with $2 \mu \mathrm{M}$ VSV-8 (solid bars), or irradiated bm19 splenocytes pulsed with $2 \mu \mathrm{M}$ MI B chain p7-15 (hashed bars). To determine the proliferative capacity of TCR $\mathrm{V}_{\beta} 9 / 12^{-} \mathrm{bm} 19$ anti-BALB/c, bm19 anti-VSV-8, and bm19 anti-MI B chain p7-15 CTL, 1 X $10^{5}$ cells from each culture were transferred on day four to a 96-well plate and incubated for $18 \mathrm{~h}$ with 2 $\mu \mathrm{Ci}$ of ${ }^{3} \mathrm{H}-\mathrm{TdR}$.

B. $1^{\circ} \mathrm{bm} 19$ anti-BALB/c CTL (filled symbols) and TCR $\mathrm{V}_{\beta} 9 / 12^{-} 1^{\circ} \mathrm{bm} 19$ anti-BALB/c CTL (open symbols) were incubated with P815 (O) or EL-4 $(\triangle){ }^{51}$ Cr-labeled target cells for $4 \mathrm{~h}$. Supernatants $(100 \mu \mathrm{l})$ were collected and cytolytic activity was represented as the "percent specific lysis". A single representative of three separate experiments is shown.

C. $1^{\circ}$ bm19 anti-VSV-8 CTL (filled symbols) and TCR V ${ }_{\beta} 9 / 12^{-} 1^{\circ}$ bm19 anti-VSV-8 CTL (open symbols) were incubated with ${ }^{51}$ Cr-labeled S.bm19 target cells in the presence $(\mathrm{O})$ or absence $(\triangle)$ of $2 \mu \mathrm{M}$ VSV-8 for $4 \mathrm{~h}$. Supernatants $(100 \mu \mathrm{l})$ were collected and cytolytic activity was represented as the "percent specific lysis". A single representative of three separate experiments is shown.

D. $1^{\circ}$ bm19 anti-MI B chain p7-15 CTL (filled symbols) and TCR V $\mathrm{V}_{\beta} 9 / 12^{-} 1^{\circ} \mathrm{bm} 19$ antiMI B chain p7-15 CTL (open symbols) were incubated with ${ }^{51}$ Cr-labeled S.bm19 target cells in the presence $(\mathrm{O})$ or absence $(\triangle)$ of $2 \mu \mathrm{M}$ MI B chain p7-15 for $4 \mathrm{~h}$. 
Supernatants $(100 \mu \mathrm{l})$ were collected and cytolytic activity was represented as the "percent specific lysis". A single representative of three separate experiments is shown. 

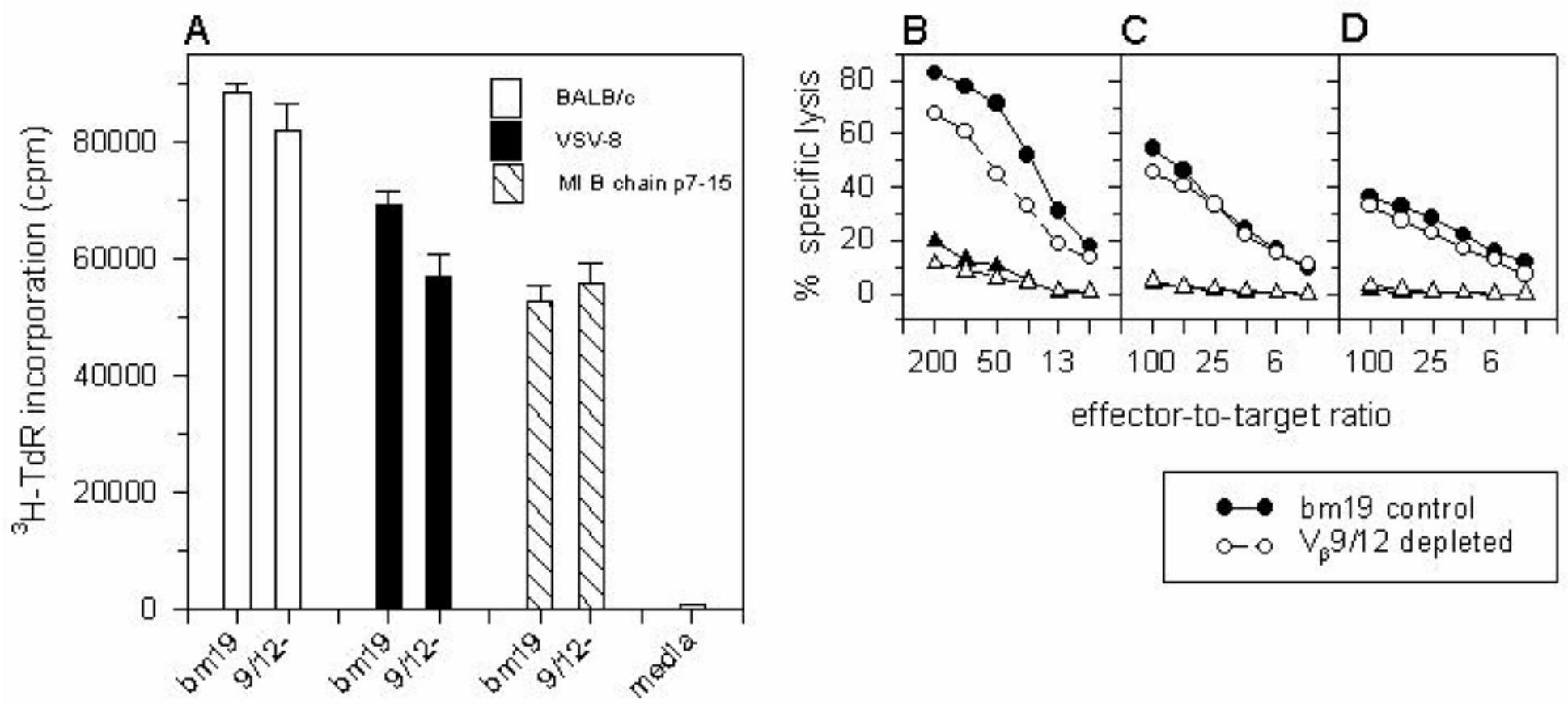

- bm19 control o- $\vee_{\beta} 9 / 12$ depleted 


\section{REFERENCES}

1. d'Ivernois, C., M. Dupon, J. F. Dartigues, L. Potaux, M. Aparicio, and J. Y. Lacut. 1991. Decreased incidence of infection after renal transplantation with the use of cyclosporine. Eur.J Clin.Microbiol.Infect.Dis. 10:911-916.

2. Jamil, B., K. Nicholls, G. J. Becker, and R. G. Walker. 1999. Impact of acute rejection therapy on infections and malignancies in renal transplant recipients. Transplantation 68:1597-1603.

3. Penn, I. 1991. The changing pattern of posttransplant malignancies. Transplant.Proc. 23:1101-1103.

4. Sheil, A. G., A. P. Disney, T. H. Mathew, B. E. Livingston, and A. M. Keogh. 1997. Lymphoma incidence, cyclosporine, and the evolution and major impact of malignancy following organ transplantation. Transplant.Proc. 29:825-827.

5. Baker, M. S., X. Chen, A. R. Rotramel, J. J. Nelson, B. Lu, C. Gerard, Y. Kanwar, and D. B. Kaufman. 2003. Genetic deletion of chemokine receptor CXCR3 or antibody blockade of its ligand IP-10 modulates posttransplantation graft-site lymphocytic infiltrates and prolongs functional graft survival in pancreatic islet allograft recipients. Surgery 134:126-133.

6. Hancock, W. W., N. M. Thomson, and R. C. Atkins. 1983. Composition of interstitial cellular infiltrate identified by monoclonal antibodies in renal biopsies of rejecting human renal allografts. Transplantation 35:458-463. 
7. Kalwak, K., D. Turkiewicz, M. Ussowicz, E. Gorczynska, J. Toporski, R. Ryczan, B. Rybka, D. Noworolska-Sauren, and A. Chybicka. 2003. Clinical value of the flow cytometric method for measuring lymphocyte subset activation: spontaneous activation of T-cell subpopulations is associated with acute GvHD. Transplant.Proc. $35: 1559-1562$.

8. Pefaur, J., R. Trivino, C. Navarrete, E. Oberhauser, M. Melys, I. Morales, P. Salinas, and A. Mocarquer. 2003. Clinical graft evolution of lymphocytes, polymorphonuclear cells, and antigen expression in tubular renal cells in the urine sediment of 20 renal allograft recipients. Transplant.Proc. 35:2500-2505.

9. Posselt, A. M., F. Vincenti, M. Bedolli, M. Lantz, J. P. Roberts, and R. Hirose. 2003. CD69 expression on peripheral CD8 $\mathrm{T}$ cells correlates with acute rejection in renal transplant recipients. Transplantation 76:190-195.

10. Bjorkman, P. J., M. A. Saper, B. Samraoui, W. S. Bennett, J. L. Strominger, and D. C. Wiley. 1987. The foreign antigen binding site and $\mathrm{T}$ cell recognition regions of class I histocompatibility antigens. Nature 329:512-518.

11. Dembic, Z., W. Haas, S. Weiss, J. McCubrey, H. Kiefer, H. von Boehmer, and M. Steinmetz. 1986. Transfer of specificity by murine $\alpha$ and $\beta$ T-cell receptor genes. Nature 320:232-238.

12. Gascoigne, N. R., Y. Chien, D. M. Becker, J. Kavaler, and M. M. Davis. 1984. Genomic organization and sequence of T-cell receptor $\beta$-chain constant- and joiningregion genes. Nature 310:387-391. 
13. van der Merwe, P. A. and S. J. Davis. 2003. Molecular interactions mediating T cell antigen recognition. Annu.Rev.Immunol. 21:659-684.

14. Bonneville, M., J. P. Moisan, J. F. Moreau, I. Bouyge, M. M. Hallet, M. P. Lefranc, and J. P. Soulillou. 1988. TCR $\alpha, \beta$, and $\gamma$ gene rearrangements in human alloreactive T cell clones extracted from a rejected kidney. Transplant.Proc. 20:196-198.

15. Ota, M., M. J. Geiger, S. Rosen-Bronson, C. K. Hurley, and D. D. Eckels. 1996. Diverse usage of human T-cell receptor gene segments in HLA-DR1 allospecific T cell clones. Hum.Immunol. 49:122-129.

16. Garboczi, D. N., P. Ghosh, U. Utz, Q. R. Fan, W. E. Biddison, and D. C. Wiley. 1996. Structure of the complex between human T-cell receptor, viral peptide and HLA-A2. Nature 384:134-141.

17. Henderson, R. A., A. L. Cox, K. Sakaguchi, E. Appella, J. Shabanowitz, D. F. Hunt, and V. H. Engelhard. 1993. Direct identification of an endogenous peptide recognized by multiple HLA-A2.1-specific cytotoxic $\mathrm{T}$ cells. Proc.Natl.Acad.Sci.U.S.A 90:10275-10279.

18. Lauzurica, P., R. Bragado, D. Lopez, B. Galocha, and J. A. Lopez de Castro. 1992. Asymmetric selection of $\mathrm{T}$ cell antigen receptor $\alpha$ - and $\beta$-chains in HLA-B27 alloreactivity. J Immunol. 148:3624-3630.

19. Li, Y. Y., K. D. Smith, Y. Shi, and C. T. Lutz. 1996. Alloreactive anti-HLA-B7 cytolytic $\mathrm{T}$ cell clones use restricted $\mathrm{T}$ cell receptor genes. Transplantation 62:954961. 
20. Heath, W. R. and L. A. Sherman. 1991. Cell-type-specific recognition of allogeneic cells by alloreactive cytotoxic $\mathrm{T}$ cells: a consequence of peptide-dependent allorecognition. Eur.J Immunol. 21:153-159.

21. Kappler, J. W., U. Staerz, J. White, and P. C. Marrack. 1988. Self-tolerance eliminates T cells specific for Mls-modified products of the major histocompatibility complex. Nature 332:35-40.

22. Mannon, R. B., B. L. Kotzin, E. Roper, C. Nataraj, R. J. Kurlander, and T. M. Coffman. 1996. The intragraft $\mathrm{CD} 8^{+} \mathrm{T}$ cell response in renal allograft rejection in the mouse. Transplantation 62:96-104.

23. Udaka, K., T. J. Tsomides, and H. N. Eisen. 1992. A naturally occurring peptide recognized by alloreactive $\mathrm{CD} 8^{+}$cytotoxic $\mathrm{T}$ lymphocytes in association with a class I MHC protein. Cell 69:989-998.

24. Grandea, A. G., III and M. J. Bevan. 1993. A conservative mutation in a class I MHC molecule outside the peptide binding groove stimulates responses to self peptides. $J$ Immunol. 151:3981-3987.

25. Lewis, J., M. Foo, S. S. Geier, P. A. Kumar, S. G. Nathenson, and J. A. Bluestone. 1988. Cytotoxic T lymphocyte recognition of novel allodeterminants expressed on in vitro selected $\mathrm{H}-2 \mathrm{~K}^{\mathrm{b}}$ mutants. J Immunol. 141:728-735.

26. Melvold, R. W., H. I. Kohn, and G. R. Dunn. 1982. History and genealogy of the $\mathrm{H}-2 \mathrm{~K}^{\mathrm{b}}$ mutants from the C57BL/6Kh colony. Immunogenetics 15:177-185. 
27. Goss, J. A., R. Pyo, M. W. Flye, J. M. Connolly, and T. H. Hansen. 1993. Major histocompatibility complex-specific prolongation of murine skin and cardiac allograft survival after in vivo depletion of $\mathrm{V}_{\beta}{ }^{+} \mathrm{T}$ cells. $J$ Exp.Med. 177:35-44.

28. Lewis, J., M. Foo, S. S. Geier, P. A. Kumar, S. G. Nathenson, and J. A. Bluestone. 1988. Cytotoxic T lymphocyte recognition of novel allodeterminants expressed on in vitro selected $\mathrm{H}-2 \mathrm{~K}^{\mathrm{b}}$ mutants. J Immunol. 141:728-735.

29. Horig, H., A. C. Young, N. J. Papadopoulos, T. P. DiLorenzo, and S. G. Nathenson. 1999. Binding of longer peptides to the $\mathrm{H}-2 \mathrm{~K}^{\mathrm{b}}$ heterodimer is restricted to peptides extended at their $\mathrm{C}$ terminus: refinement of the inherent MHC class I peptide binding criteria. J Immunol. 163:4434-4441.

30. Saito, N. G., H. C. Chang, and Y. Paterson. 1999. Recognition of an MHC class Irestricted antigenic peptide can be modulated by para-substitution of its buried tyrosine residues in a TCR-specific manner. J Immunol. 162:5998-6008.

31. Sheil, J. M., S. E. Shepherd, G. F. Klimo, and Y. Paterson. 1992. Identification of an autologous insulin $\mathrm{B}$ chain peptide as a target antigen for $\mathrm{H}-2 \mathrm{~K}^{\mathrm{b}}$-restricted cytotoxic T lymphocytes. $J$ Exp.Med. 175:545-552.

32. Kohler, G. and C. Milstein. 1976. Derivation of specific antibody-producing tissue culture and tumor lines by cell fusion. Eur.J Immunol. 6:511-519.

33. Ozato, K. and D. H. Sachs. 1981. Monoclonal antibodies to mouse MHC antigens. III. Hybridoma antibodies reacting to antigens of the $\mathrm{H}-2^{\mathrm{b}}$ haplotype reveal genetic control of isotype expression. J Immunol. 126:317-321. 
34. Ralph, P. 1973. Retention of lymphocyte characteristics by myelomas and $\theta_{+}^{+}-$ lymphomas: sensitivity to cortisol and phytohemagglutinin. J Immunol. 110:14701475.

35. Ralph, P. and I. Nakoinz. 1974. Lipopolysaccharides inhibit lymphosarcoma cells of bone marrow orgin. Nature 249:49-51.

36. Plaut, M., L. M. Lichtenstein, E. Gillespie, and C. S. Henney. 1973. Studies on the mechanism of lymphocyte-mediated cytolysis. IV. Specificity of the histamine receptor on effector T cells. J Immunol. 111:389-394.

37. Sheil, J. M., T. D. Schell, S. E. Shepherd, G. F. Klimo, J. M. Kioschos, and Y. Paterson. 1994. Presentation of a horse cytochrome $c$ peptide by multiple $\mathrm{H}-2^{\mathrm{b}}$ class I major histocompatibility complex (MHC) molecules to C57BL/6- and bm1-derived cytotoxic T lymphocytes: presence of a single MHC anchor residue may confer efficient peptide-specific CTL recognition. Eur.J Immunol. 24:2141-2149.

38. Ledbetter, J. A., R. V. Rouse, H. S. Micklem, and L. A. Herzenberg. 1980. T cell subsets defined by expression of Lyt-1,2,3 and Thy-1 antigens. Two-parameter immunofluorescence and cytotoxicity analysis with monoclonal antibodies modifies current views. J Exp.Med. 152:280-295.

39. Necker, A., N. Rebai, M. Matthes, E. Jouvin-Marche, P. A. Cazenave, P. Swarnworawong, E. Palmer, H. R. MacDonald, and B. Malissen. 1991. Monoclonal antibodies raised against engineered soluble mouse $\mathrm{T}$ cell receptors and specific for $\mathrm{V}_{\alpha}$ 8-, $\mathrm{V}_{\beta}$ 2- or $\mathrm{V}_{\beta}$ 10-bearing $\mathrm{T}$ cells. Eur.J Immunol. 21:3035-3040. 
40. Tomonari, K., E. Lovering, and S. Spencer. 1990. Correlation between the $\mathrm{V}_{\beta} 4^{+}$ $\mathrm{CD} 8^{+} \mathrm{T}$-cell population and the $\mathrm{H}-2^{\mathrm{d}}$ haplotype. Immunogenetics 31:333-339.

41. Bill, J., O. Kanagawa, J. Linten, Y. Utsunomiya, and E. Palmer. 1990. Class I and class II MHC gene products differentially affect the fate of $\mathrm{V}_{\beta} 5$ bearing thymocytes. J Mol.Cell Immunol. 4:269-279.

42. Haqqi, T. M., S. Banerjee, G. D. Anderson, and C. S. David. 1989. RIII S/J (H-2r). An inbred mouse strain with a massive deletion of $\mathrm{T}$ cell receptor $\mathrm{V}_{\beta}$ genes. $J$ Exp.Med. 169:1903-1909.

43. Okada, C. Y., B. Holzmann, C. Guidos, E. Palmer, and I. L. Weissman. 1990. Characterization of a rat monoclonal antibody specific for a determinant encoded by the $\mathrm{V}_{\beta} 7$ gene segment. Depletion of $\mathrm{V}_{\beta} 7^{+} \mathrm{T}$ cells in mice with Mls-1a haplotype. $J$ Immunol. 144:3473-3477.

44. Kanagawa, O. 1988. Antibody-mediated activation of T cell clones as a method for screening hybridomas producing antibodies to the T cell receptor. J Immunol.Methods 110:169-178.

45. Behlke, M. A., H. S. Chou, K. Huppi, and D. Y. Loh. 1986. Murine T-cell receptor mutants with deletions of $\beta$-chain variable region genes. Proc.Natl.Acad.Sci.U.S.A $83: 767-771$.

46. Bill, J., O. Kanagawa, D. L. Woodland, and E. Palmer. 1989. The MHC molecule I-E is necessary but not sufficient for the clonal deletion of $\mathrm{V}_{\beta}$ 11-bearing $\mathrm{T}$ cells. $J$ Exp.Med. 169:1405-1419. 
47. Liao, N. S., J. Maltzman, and D. H. Raulet. 1989. Positive selection determines T cell receptor $\mathrm{V}_{\beta} 14$ gene usage by $\mathrm{CD} 8^{+} \mathrm{T}$ cells. $J$ Exp.Med. 170:135-143.

48. Cazenave, P. A., P. N. Marche, E. Jouvin-Marche, D. Voegtle, F. Bonhomme, A. Bandeira, and A. Coutinho. 1990. $\mathrm{V}_{\beta} 17$ gene polymorphism in wild-derived mouse strains: two amino acid substitutions in the $\mathrm{V}_{\beta} 17$ region greatly alter $\mathrm{T}$ cell receptor specificity. Cell 63:717-728.

49. Watanabe-Ohnishi, R., D. E. Low, A. McGeer, D. L. Stevens, P. M. Schlievert, D. Newton, B. Schwartz, B. Kreiswirth, and M. Kotb. 1995. Selective depletion of $\mathrm{V}_{\beta^{-}}$ bearing $\mathrm{T}$ cells in patients with severe invasive group A streptococcal infections and streptococcal toxic shock syndrome. Ontario Streptococcal Study Project. $J$ Infect.Dis. 171:74-84.

50. Grandea, A. G., III and M. J. Bevan. 1992. Single-residue changes in class I major histocompatibility complex molecules stimulate responses to self peptides. Proc.Natl.Acad.Sci.U.S.A 89:2794-2798.

51. Doherty, D. G., J. E. Penzotti, D. M. Koelle, W. W. Kwok, T. P. Lybrand, S. Masewicz, and G. T. Nepom. 1998. Structural basis of specificity and degeneracy of $\mathrm{T}$ cell recognition: pluriallelic restriction of $\mathrm{T}$ cell responses to a peptide antigen involves both specific and promiscuous interactions between the $\mathrm{T}$ cell receptor, peptide, and HLA-DR. J Immunol. 161:3527-3535. 
52. Shepherd, S. E., R. Sun, S. G. Nathenson, and J. M. Sheil. 1992. Selective reactivity of CD8-independent $\mathrm{T}$ lymphocytes to a cytotoxic $\mathrm{T}$ lymphocyte-selected $\mathrm{H}-2 \mathrm{~K}^{\mathrm{b}}$ mutant altered at position 222 in the $\alpha 3$ domain. Eur.J Immunol. 22:647-653.

53. Sheil, J. M., M. J. Bevan, and L. Lefrancois. 1987. Characterization of dual-reactive $\mathrm{H}-2 \mathrm{~K}^{\mathrm{b}}$-restricted anti-vesicular stomatitus virus and alloreactive cytotoxic T cells. $J$ Immunol. 138:3654-3660.

54. Goronzy, J., U. Schaefer, K. Eichmann, and M. M. Simon. 1981. Quantitative studies on T cell diversity. II. Determination of the frequencies and Lyt phenotypes of two types of precursor cells for alloreactive cytotoxic $\mathrm{T}$ cells in polyclonally and specifically activated splenic T cells. J Exp.Med. 153:857-870.

55. Trizio, D. and G. Cudkowicz. 1974. Separation of T and B lymphocytes by nylon wool columns: evaluation of efficacy by functional assays in vivo. J Immunol. 113:1093-1097.

56. Penn, I. 1996. Cancers in cyclosporine-treated versus azathioprine-treated patients. Transplant.Proc. 28:876-878.

57. Rubin, R. H., J. S. Wolfson, A. B. Cosimi, and N. E. Tolkoff-Rubin. 1981. Infection in the renal transplant recipient. Am.J Med. 70:405-411.

58. Swinnen, L. J., M. R. Costanzo-Nordin, S. G. Fisher, E. J. O'Sullivan, M. R. Johnson, A. L. Heroux, G. J. Dizikes, R. Pifarre, and R. I. Fisher. 1990. Increased incidence of lymphoproliferative disorder after immunosuppression with the 
monoclonal antibody OKT3 in cardiac-transplant recipients. N.Engl.J Med. 323:17231728.

59. Euvrard, S., J. Kanitakis, and A. Claudy. 2003. Skin cancers after organ transplantation. N.Engl.J Med. 348:1681-1691.

60. Bevan, M. J. and T. Hunig. 1981. T cells respond preferentially to antigens that are similar to self H-2. Proc.Natl.Acad.Sci.U.S.A 78:1843-1847.

61. Torabi-Pour, N., W. J. Morrow, R. Saffie, P. G. Gowda, D. Perrett, and T. R. Oliver. 2003. Identification and quantification of antigens associated with HLA class I molecules on a bladder tumour cell line. Implications for vaccine design. Urol.Int. 70:154-160.

62. Sanjeevi, C. B., T. P. Lybrand, S. Stevanovic, and H. G. Rammensee. 2002. Molecular modeling of eluted peptides from DQ6 molecules (DQB1*0602 and DQB1*0604) negatively and positively associated with type 1 diabetes. Ann.N.Y.Acad.Sci. 958:317-320.

63. Rosset, M. B., V. Tieng, D. Charron, and A. Toubert. 2003. Differences in MHCclass I presented minor histocompatibility antigens extracted from normal and graftversus-host disease (GVHD) mice. Clin.Exp.Immunol. 132:46-52.

64. Altman, J. D., P. A. Moss, P. J. Goulder, D. H. Barouch, M. G. McHeyzer-Williams, J. I. Bell, A. J. McMichael, and M. M. Davis. 1996. Phenotypic analysis of antigenspecific T lymphocytes. Science 274:94-96. 
65. McMichael, A. J. and C. A. O'Callaghan. 1998. A new look at T cells. $J$ Exp.Med. 187:1367-1371.

66. Goss, J. A., M. A. Alexander-Miller, J. Gorka, M. W. Flye, J. M. Connolly, and T. H. Hansen. 1993. Specific prolongation of allograft survival by a T-cell-receptor-derived peptide. Proc.Natl.Acad.Sci.U.S.A 90:9872-9876. 


\section{CHAPTER 5}

Depletion of $\mathrm{V}_{\beta} 9^{+}$and $\mathrm{V}_{\beta} 12^{+} \mathrm{T}$ cells in bm19 mutant mice enhances the survival of C57BL/6 skin allografts without disrupting antigen-specific cell-mediated immunity

Marc A. Frankenberry ${ }^{1}$, Rosana Schafer $^{1}$, William Tarry ${ }^{2}$, and James M. Sheil ${ }^{1}$

Department of Microbiology, Immunology \& Cell Biology ${ }^{1}$, Department of Surgery ${ }^{2}$, West Virginia University School of Medicine, Morgantown, WV 26506-9177 


\begin{abstract}
The clinical application of immunosuppressive drug therapy in transplantation medicine has resulted in the progressive development of successful allograft survival for a highly diverse set of organ and tissue transplants. These agents, however, are nonspecific and affect the overall immune status of transplant recipients, causing generalized inhibition of $\mathrm{T}$ cell responsiveness, thus leaving these patients susceptible to higher rates of opportunistic infection and malignancy. Since $\mathrm{CD}^{+} \mathrm{T}$ cells play an integral role in transplant rejection, we propose that the identification and elimination of TCR $\mathrm{V}_{\beta}{ }^{+}$CTLs actively involved in the alloreactive response will result in the maintenance of the graft recipients immune system. We have previously identified two distinct TCR $V_{\beta}$ families $-V_{\beta} 9$ and $V_{\beta} 12$ - as critical effectors in the alloreactive response of bm19 anti-B6 MLCs that act synergistically in the recognition of $\mathrm{H}-2 \mathrm{~K}^{\mathrm{b}}$ bearing targets. Interestingly, the in vitro depletion of $\mathrm{V}_{\beta} 9^{+}$and $\mathrm{V}_{\beta} 12^{+} \mathrm{T}$ cells from the bm19 $\mathrm{T}$ cell repertoire does not impair antigen-specific responsiveness to the immunogenic peptides, VSV-8 and MI p7-15. In the present study, we show that the in vivo depletion of both $\mathrm{TCR} \mathrm{V}_{\beta}$ families significantly prolong B6 skin allograft survival when transplanted onto bm19 mice. We also demonstrate that bm19 mice are capable of mounting a cell-mediated immune response against L. monocytogenes after the in vivo removal of TCR $\mathrm{V}_{\beta} 9 / 12^{+}$CTLs. These findings suggest that the selective depletion of allograft-specific $\mathrm{V}_{\beta}{ }^{+}$CTLs can prolong graft survival without disrupting the host immune response and without the use of nonspecific immunosuppressive agents.
\end{abstract}




\section{INTRODUCTION}

The administration of immunosuppressive drugs is the major therapeutic option for the prevention of allograft rejection and is largely responsible for the success of clinical transplantation. These agents, however, also adversely affect the overall immune status of transplant patients, leaving these patients susceptible to opportunistic infections and malignancies (1-4). Despite current advances in immunosuppressive therapies, these treatment modalities predispose the transplant recipient to infection $(5,6)$. It has been noted that, depending upon the intensity of immunosuppression, 52 to 86 percent of renal transplant patients experienced one or more episodes of infection during the first 6 months post transplantation (2). The rates of infection, mortality and overall morbidity remain comparable in hepatic, cardiac, lung and pancreatic islet transplant recipients despite the therapeutic use of immunosuppressive agents (7-10).

The number of patients with end-stage renal disease has increased by 7 to 8 percent per year in the United States (11). The limited number of kidneys available for transplantation, reported as between 6200 living and 8500 cadaveric donors $(11,12)$, precludes the only currently available treatment modality for these patients (13). With the use of immunosuppressive agents, such as cyclosporine A, tacrolimus, corticosteroids, and more recently muromonab-CD3 (OKT3) and mycophenolate mofetil, the one-year survival rate of renal grafts has increased from 88.8 to 93.9 percent with living donors and 75.7 to 87.7 percent with cadaveric donors from 1988 to 1996 (11).

In addition to traditional immunosuppressive medications, extensive research has been focused on developing immunomodulatory agents aimed at blocking interleukin-2

receptor (IL-2R) engagement. Daclizumab (Zenapax), basiliximab, Simulect, anti-Tac 
and BT563 are humanized mAb specific for cluster of differentiation 25 (CD25), the IL-2R $\alpha$ chain induced by antigenic stimulation $(14,15)$. These agents have been shown to reduce allograft rejection in renal transplantation recipients by 49 percent at six months post transplantation when added to cyclosporine A, prednisolone and mycophenolate mofetil or azathioprine regimen (14). This treatment modality, however, did not reduce the incidence of malignancies or risk of infection for renal transplant recipients. Likewise, daclizumab, in conjunction with cyclosporine A, corticosteroids and mycophenolate mofetil, was effective in preventing alloreactivity and acute rejection in cardiac transplantation during a 3 month trial (15). Unfortunately, IL-2R mAb diminish the total number of all activated T-cells regardless of whether these cells have been activated by antigen-specific or allogeneic stimulation, thus predisposing the transplant recipient to higher rates of infectious and malignant illnesses.

Several other immunomodulatory agents have been studied as adjuvants to traditional immunosuppresion. Alemtuzumab (Campath-1H) when combined with tacrolimus is reported to prevent acute rejection in human intestinal transplantation (16). Campath- $1 \mathrm{H}$ is a humanized mAb directed against the CD52 antigen, a pan T, B, NK cell and monocyte marker. Likewise, FTY720 has been shown to reduce intestinal allograft rejection in rats (17). FTY720 reduces the total number of circulating lymphocytes and increases lymphocyte homing to lymphoid tissues, including mesenteric lymph nodes and Peyer's patches (18), and reduces the total $\mathrm{CD}^{+}$cell number in skin allografts (19). Koppi and collaborators (20) investigated the effects of blocking CMRF-44, a dendritic cell (DC)-associated differentiation-activation antigen, on allogeneic bone marrow transplantation (BMT) and solid organ transplantation. They determined that 89 percent 
of activated DCs are depleted by CMRF-44-dependent complement-mediated lysis and subsequently reduce $\mathrm{T}$ helper type 1 and type 2 responses (20).

Unfortunately, all of the immunosuppressive agents mentioned above act in a nonselective manner and therefore reduce the overall immune status of the patient. We employ a unique in vitro murine model system to distinguish allospecific CTL effectors from the remaining splenic $\mathrm{T}$ cell repertoire in bm19 mutant mice stimulated with allogeneic B6 spleen cells, based on their $\mathrm{V}_{\beta}$ expression (Frankenberry et al., submitted). Thus, by identifying and eliminating only those $\mathrm{V}_{\beta}{ }^{+}$CTLs actively involved in the alloreactive response, we can maintain the majority of the patient's immune system.

The bm19 mutant differs from the parental B6 strain by a single amino acid change in the class $\mathrm{I} H-2 \mathrm{~K}^{\mathrm{b}}$, resulting in a $\mathrm{Thr}^{80} \rightarrow$ Asn substitution. As previously demonstrated in vitro (Frankenberry et al, submitted), although five distinct $\mathrm{V}_{\beta}$ families $\left(\mathrm{V}_{\beta} 8.1 / 8.2, \mathrm{~V}_{\beta} 9, \mathrm{~V}_{\beta} 10, \mathrm{~V}_{\beta} 12\right.$ and $\left.\mathrm{V}_{\beta} 14\right)$ show increased expansion when bm19 splenocytes are stimulated with irradiated splenocytes from the parental B6 strain, only $\mathrm{V}_{\beta} 9^{+}$and $\mathrm{V}_{\beta} 12^{+} \mathrm{CTL}$ effectors show cytolytic activity against allogeneic $\mathrm{K}^{\mathrm{b}}$-expressing target cells. Furthermore, depletion of both $\mathrm{V}_{\beta} 9^{+}$and $\mathrm{V}_{\beta} 12^{+} \mathrm{CD} 8^{+} \mathrm{T}$ cells results in a dramatic reduction in the lytic responsiveness of bm19 anti-B6 alloreactive CTL effectors. Similarly, enrichment for $\mathrm{V}_{\beta} 9^{+}$and $\mathrm{V}_{\beta} 12^{+}$CTLs significantly increases their lytic activity against $\mathrm{H}-2 \mathrm{~K}^{\mathrm{b}}$-expressing targets (Frankenberry et al, submitted). Thus these experiments strongly implicate $C D 8^{+} T$ cells from both $V_{\beta} 9$ and $V_{\beta} 12$ families as critical alloreactive effectors in this bm19 anti-B6 model. Importantly, we also find that depletion of $\mathrm{V}_{\beta} 9^{+}$and $\mathrm{V}_{\beta} 12^{+} \mathrm{CD} 8^{+} \mathrm{T}$ cells from the bm19 $\mathrm{T}$ cell repertoire does not impair the antigen-specific responsiveness of bm19 CTLs to the immunogenic peptides, 
vesicular stomatitis virus nucleoprotein p52-59 (VSV-8) $(21,22)$ and mouse insulin I (MI) B chain $\mathrm{p} 7-15$ (23). These findings suggest that removal of both TCR $\mathrm{V}_{\beta}$ families in vivo should significantly prolong B6 skin allograft survival when transplanted onto bm19 mice.

To address whether $C D 8^{+} T$ cells from the $\mathrm{V}_{\beta} 9$ and $\mathrm{V}_{\beta} 12$ families are the primary alloreactive CTL effectors involved in the rejection of B6 skin allografts, we administer intraperitoneal (i.p.) monoclonal antibody (mAb) injections of $500 \mu \mathrm{g}$ antiHemagglutinin A (HemA) isotype control (24), $500 \mu \mathrm{g}$ anti-TCR $\mathrm{V}_{\beta} 9$ [MR10-2] (25) or $750 \mu \mathrm{g}$ anti-TCR $\mathrm{V}_{\beta} 12$ [MR11-1] (25) $\mathrm{mAb}$ in $200 \mu \mathrm{L}$ sterile PBS on days $-3,0,+3$ and +21 of skin graft placement and determine B6 skin allograft survival. In this paper, we show that in vivo depletion of either $\mathrm{V}_{\beta} 9^{+}$or $\mathrm{V}_{\beta} 12^{+} \mathrm{T}$ cell populations from naïve bm19 mice prolongs the survival of B6 skin allografts, and the simultaneous depletion of both $\mathrm{V}_{\beta} 9$ and $\mathrm{V}_{\beta} 12^{+} \mathrm{T}$ cells further enhances $\mathrm{B} 6$ skin allograft survival, when compared to saline and isotype controls. Furthermore, although depletion of the $V_{\beta} 9$ and $V_{\beta} 12$ families removes more than $10 \%$ of the $\mathrm{CD} 8^{+} \mathrm{T}$ lymphocyte repertoire, these bm19 mice are unimpaired in their ability to efficiently clear a Listeria monocytogenes infection. 


\section{MATERIALS AND METHODS}

\section{Animals}

Female C57BL/6 (B6) and B6.C-H-2 ${ }^{\mathrm{bm} 19}$ (bm19) (26) mice used in this study were obtained from this laboratory's breeding colony at West Virginia University Health Sciences Center Vivarium. The B6 breeding colony was established in 1987 and has been maintained since then at West Virginia University Health Sciences Center Vivarium. All female mice used in this study were 8-12 weeks of age.

Antibodies and flow cytometry

Phycoerythin (PE)-conjugated anti-CD8 $\alpha$ [53-6.7] (27) and fluorescein isothiocyanate (FITC)-conjugated anti- $\mathrm{V}_{\beta} 9$ [MR10-2] (25), and $\mathrm{V}_{\beta} 12$ [MR11-1] (25) mAbs were purchased from Pharmingen (C) (Becton Dickinson, Mountain View, CA). Harvested splenocytes, $5 \times 10^{5}$, were incubated for $45 \mathrm{~min}$ on ice with $20 \mu$ l $(1: 100)$ FITCconjugated anti-TCR $\mathrm{V}_{\beta}$-specific $\mathrm{mAb}$ and $20 \mu \mathrm{l}$ (1:96) of PE-conjugated anti-CD8 $\alpha$ mAb. The cells were then washed twice with $1 \mathrm{X}$ PBS and fixed in $500 \mu 11 \%$ formalin. Fixed cells were analyzed for fluorescence intensity using a FACScan ${ }^{\circledR}$ flow cytometer (Becton Dickinson, Mountain View, CA). The percentage expression of cells of a given $\mathrm{V}_{\beta}$ family among $\mathrm{CD}^{+}$alloreactive CTLs is defined as $100 \mathrm{X}\left(\mathrm{V}_{\beta \mathrm{n}}\right.$ value/sum of $\mathrm{V}_{\beta}$ values) X 100, as described previously (28). 
In vivo depletion of $V_{\beta}$-specific TCR families

$\mathrm{T}$ cells from the $\mathrm{V}_{\beta} 9$ and/or $\mathrm{V}_{\beta} 12$ families were depleted in vivo as previously described by Connolly and coworkers (29) with the following modifications: Female bm19 mice were injected i.p. with $500 \mu \mathrm{g}$ anti-HemA isotype control (24), $500 \mu \mathrm{g}$ anti- $\mathrm{V}_{\beta} 9$ [MR10-2] (25) or $750 \mu \mathrm{g}$ anti- $\mathrm{V}_{\beta} 12$ [MR11-1] (25) mAb in $200 \mu \mathrm{L}$ sterile PBS on days $3,0,+3$ and +21 of skin graft placement. The isotype control, anti-HemA, was kindly provided by Dr. Elliott (24). Five bm19 mice from each experimental or control group were sacrificed on days $+3,+7,+14,+21,+24,+28$ and +35 , and spleens were removed, processed and evaluated by flow cytometry to determine the percentage of $\mathrm{V}_{\beta} 9^{+}$and $\mathrm{V}_{\beta} 12^{+} \mathrm{CD} 8^{+} \mathrm{T}$ lymphocytes.

\section{Skin allograft transplantation}

Preparation of skin allografts and recipient mice was performed as described by Billingham and Steinmuller $(30,31)$ with the following modifications: On day 0 , recipient female bm19 mice were weighed and anesthetized by i.m. injection with a combination of xylazine $(5 \mathrm{mg} / \mathrm{kg})$ and ketamine $(95 \mathrm{mg} / \mathrm{kg})$. Anesthetized mice were shaved on the dorsal surface from the shoulder blades to the hind limbs using mouse sheers; the surface was moistened with sterilized water and allowed to air dry. The shaved area was then treated with a depilatory agent to remove any remaining hair and subsequently removed with sterilized water and gauze padding. The graft area was cleaned with betadine and allowed to air dry.

Skin sections $(8 \mathrm{~mm})$ from the right and left flank were isolated using a circular biopsy punch; tissues were placed in sterile PBS and any remaining connective tissue was 
removed using forceps. Donor grafts $(8 \mathrm{~mm})$ obtained from female B6 or bm19 mice were placed directly on the graft area at an $180^{\circ}$ orientation opposite to normal hair growth. Each bm19 recipient received an allograft (B6) and a control graft (bm19). Graft sites were secured using a 3/4-inch double surgical tape bandage wrap. Engrafted mice were placed in a micro-isolator cage on a slide warmer set at $37^{\circ} \mathrm{C}$ until their recovery from the anesthetic (approximately 15-30 minutes). Protective bandage wraps were removed on day +7 , and triple antibiotic cream was applied to the graft sites to prevent potential infection. Grafts were visually monitored daily for signs of rejection, and caliper measurements were used to quantitate the extent of viability for each skin graft.

\section{Listeria monocytogenes infection}

Female bm19 mice (n=8 per group) were injected (i.p.) with 1 X PBS, $500 \mu$ g anti-HemA $\mathrm{mAb}$, or $500 \mu \mathrm{g}$ of anti- $\mathrm{V}_{\beta} 9 \mathrm{mAb}$ [MR10-2] and $750 \mu \mathrm{g}$ of anti- $\mathrm{V}_{\beta} 12$ [MR11-1] on days 3, 0 , and +3 of skin engraftment. L. monocytogenes $\left(1 \times 10^{6} \mathrm{CFU}\right)$ was injected i.p. on day +3 . Livers and spleens were harvested on day +6 and +10 of infection, homogenized on a Brinkmann homogenizer and plated in triplicate on brain-heart infusion (BHI) media with an Autoplate 4000 (Spiral Biotech, Norwood, MA). Cultures were incubated for 18 $\mathrm{h}$ and counted using a CASBA 4 (Spiral Biotech, Norwood, MA) colony counter.

\section{Statistical analysis}

All statistics in this study were performed using the paired two-tailed student's T-test, with statistical significance set at $\mathrm{p}<0.05$. 


\section{RESULTS}

Depletion of $V_{\beta} 9^{+} T$ cells in vivo significantly enhances the survival of B6 skin allografts transplanted onto bm19 mice.

To determine the effect of $\mathrm{bm} 19 \mathrm{~V}_{\beta} 9^{+} \mathrm{CTLs}$ on the rejection of B6 skin allografts, we selectively depleted $\mathrm{V}_{\beta} 9^{+} \mathrm{T}$ lymphocytes from the bm19 T repertoire by administering three successive i.p. injections of $500 \mu \mathrm{g} \mathrm{V}_{\beta} 9$-specific mAb [MR10-2] on day -3, 0 and +3 of B6 skin allograft placement. As shown in Table $\mathrm{I}$, the $\mathrm{V}_{\beta} 9^{+} \mathrm{T}$ cell population is significantly reduced from $5.5 \%$ to $0.09 \%$ on day +3 . Although the bm19 $\mathrm{V}_{\beta} 9^{+}$ population remains below $1 \%$ throughout the duration of these studies, we noted a slight trend toward the recovery of $\mathrm{V}_{\beta} 9^{+}$CTLs by day +21 , expanding from $0.35 \%$ to $0.6 \%$ of total $\mathrm{CD} 8^{+} \mathrm{T}$ cells. Thus, we administered an additional i.p. injection of $500 \mu \mathrm{g}$ anti- $\mathrm{V}_{\beta} 9$ $\mathrm{mAb}$ [MR10-2] on day +21 , and the $\mathrm{CD} 8^{+} \mathrm{V}_{\beta} 9^{+} \mathrm{T}$ cell pool is subsequently reduced to $0.3 \%$ by day +24 . Conversely, treatment with an IgG1 isotype control, the anti-HemA mAb, has no significant effect on $\mathrm{V}_{\beta} 9^{+}$CTLs in bm19 mice. All bm19 control mice reject the B6 skin allograft by day +13 and thus do not require a fourth injection on day +21 .

All experimental bm19 mice that receive $\mathrm{B} 6$ allografts without $\mathrm{V}_{\beta} \mathrm{mAb}$ treatment completely reject the B6 skin allograft within 13 days post transplantation, and control bm19 mice that receive syngeneic bm19 skin grafts fully accept the transplanted tissue (Figure 1). All bm19 mice treated with the $\mathrm{V}_{\beta} 9$-specific mAb [MR 10-2] on days $-3,0$, +3 and +21 displays a significant delay in graft rejection. Although the B6 skin allograft exhibits a steady declined in size after 15 days it is maintained for 31 days $(\mathrm{p}<0.05)$. 
Similar to the saline control group, bm19 mice injected with the IgG1 isotype control, anti-HemA mAb, reject their B6 skin allografts by day +13 .

Depletion of $V_{\beta} 12^{+}$CTLs in vivo significantly enhances the survival of B6 skin allografts transplanted onto bm19 mice.

Having observed that $\mathrm{V}_{\beta} 9^{+} \mathrm{T}$ cell-depleted bm19 mice show a $>2$-fold increase in B6 skin allograft survival, we addressed whether depletion of $\mathrm{V}_{\beta} 12^{+} \mathrm{T}$ cells might have a similar effect on the ability of bm19 mice to reject B6 skin allografts. Thus, bm19 $\mathrm{V}_{\beta} 12^{+}$ $\mathrm{T}$ cells were selectively depleted in vivo by administering four $500 \mu \mathrm{g}$ i.p. injections of the $V_{\beta} 12$-specific mAb [MR11-1] on days $-3,0,+3$ and +21 of engraftment. As shown in Table I, the untreated and anti-HemA mAb treated $\mathrm{V}_{\beta} 12^{+}$populations in bm19 mice contribute between $6.0 \%$ and $6.5 \%$ of the total $\mathrm{CD} 8^{+}$cell repertoire. The $\mathrm{V}_{\beta} 12^{+} \mathrm{T}$ cells are significantly depleted following anti- $\mathrm{V}_{\beta} 12 \mathrm{mAb}$ treatment, with an initial decrease to $0.03 \%$. As described above for the $\mathrm{V}_{\beta} 9$-depleted bm19 mice, we recognized that the TCR $V_{\beta} 12$ family could potentially recover during the experiment and administered a fourth injection (i.p.) of anti- $\mathrm{V}_{\beta} 12 \mathrm{mAb}$ on day +21 to circumvent this possible complication. The TCR $\mathrm{V}_{\beta} 12^{+} \mathrm{T}$ cell population remains below $1 \%$ throughout the duration of these experiments and peaks on day +35 , well after the B6 graft is completely rejected. As noted previously, the IgG1 isotype control, anti-HemA-specific mAb, has no significant effect on the $\mathrm{CD} 8^{+} \mathrm{TCR} \mathrm{V}_{\beta} 12$ effectors in bm19 mice. Again, all bm19 mice treated with anti-HemA-specific mAb reject the B6 skin allograft by day +13 and thus does not require a fourth injection on day +21 . 
Saline control bm19 mice that received bm19 skin grafts accept the newly transplanted tissue, but those that received B6 allografts promptly reject them within 13 days (Figure 1). Likewise, isotype control bm19 mice reject the B6 allografts by day +13. The experimental group of bm19 mice, treated with four $500 \mu \mathrm{g}$ i.p. injections of the $\mathrm{V}_{\beta} 12$-specific $\mathrm{mAb}$ [11-1], show significantly increased B6 allograft survival compared those in the saline control group $(\mathrm{p}<0.05)$. Thus, $\mathrm{V}_{\beta} 12$-depleted bm19 mice do not completely reject their B6 skin allografts until day +22 , thereby prolonging graft survival $>1.5$-fold. Similar to the $\mathrm{V}_{\beta} 9$-depleted bm19 mice, the B6 skin allografts in $\mathrm{V}_{\beta} 12$-depleted bm19 mice gradually diminish in size throughout the rejection process.

The depletion of $T$ cells from both $V_{\beta} 9$ and $V_{\beta} 12$ families in vivo further increases the survival of B6 allografts in bm19 mice.

Given that in vivo depletion of $\mathrm{T}$ cells from either the $\mathrm{V}_{\beta} 9$ or $\mathrm{V}_{\beta} 12$ family results in significant enhancement of B6 allograft survival in bm19 mice, we addressed whether the combined depletion of $\mathrm{T}$ cells from both families would further enhance B6 allograft survival. To achieve depletion of both $\mathrm{V}_{\beta} 9^{+}$and $\mathrm{V}_{\beta} 12^{+} \mathrm{T}$ cells, bm19 mice were given four (i.p.) injections with the combination of $500 \mu \mathrm{g} \mathrm{V}_{\beta} 9$-specific $\mathrm{mAb}[10-2]+750 \mu \mathrm{g}$ $\mathrm{V}_{\beta} 12$-specific $\mathrm{mAb}$ [11-1], on days $-3,0,+3$ and +21 . Interestingly, we found that the volume of anti- $\mathrm{V}_{\beta} 12 \mathrm{mAb}$ required to deplete the $\mathrm{V}_{\beta} 12^{+} \mathrm{T}$ cell population, to levels comparable to previous experiments, had to be increased to $750 \mu \mathrm{g}$. As shown in Table I, the initial $\mathrm{V}_{\beta} 9 / 12$ population in untreated bm19 mice contribute approximately $11.7 \%$ of the total $C D 8^{+}$TCR $V_{\beta}$ CTL available. The number of TCR $V_{\beta} 9 / 12^{+} T$ cells is significantly decreased following treatment with anti- $\mathrm{V}_{\beta} 9 / 12 \mathrm{mAb}(0.12 \%)$, and remains 
below $1 \%$ throughout the duration of these experiments. As noted above, the IgG1 isotype control, anti-HemA-specific $m A b$, has no effect on the TCR $V_{\beta} 9 / 12$ populations in bm19 mice (data not shown).

Saline treated bm19 mice that received B6 allografts promptly reject the skin graft within 13 days, while the saline treated bm19 mice that received bm19 skin grafts accept the newly transplanted tissue (Figure 1). As noted previously, the isotype control (anti-HemA treated) bm19 mice reject the B6 allograft on day +13 . Treating bm19 mice with both anti- $\mathrm{V}_{\beta} 9$ and anti- $\mathrm{V}_{\beta} 12 \mathrm{mAb}$ significantly prolongs B6 skin graft survival as compared to saline and anti-HemA treated bm19 mice $(\mathrm{p}<0.001)$. The B6 allograft on TCR $V_{\beta} 9 / 12$ depleted mice gradually decreases in size and is completely rejected by day +36 post transplantation. Thus, the selective depletion of both TCR $V_{\beta} 9$ and $V_{\beta} 12$ CTLs acts in a synergistic manner, prolonging B6 skin allograft survival by $>2.5$-fold.

The selective removal of TCR $V_{\beta} 9 / 12^{+}$T cells in vivo does not affect the cell-mediated immune response.

Having determined that the in vivo depletion of both TCR $\mathrm{V}_{\beta} 9$ and $\mathrm{V}_{\beta} 12$ significantly prolonged the B6 skin allograft survival, we sought to determine whether the absence of these $\mathrm{T}$ cell families would substantially alter the immunological function of these bm19 mice. TCR $V_{\beta} 9 / 12$ depleted bm19 mice were evaluated for their ability to clear a systemic L. monocytogenes infection. Female bm19 mice were injected (i.p.) with $1 \mathrm{x}$ PBS, $500 \mu \mathrm{g}$ of anti-HemA mAb, or $500 \mu \mathrm{g}$ of anti- $\mathrm{V}_{\beta} 9 \mathrm{mAb}$ and $750 \mu \mathrm{g}$ of anti$\mathrm{V}_{\beta} 12 \mathrm{mAb}$ on days $-3,0$ and +3 . On day $+3,4 \mathrm{~h}$ after the third $\mathrm{mAb}$ injection, $1 \times 10^{6}$ CFU of L. monocytogenes was injected (i.p.). The spleens and livers of $L$. 
monocytogenes infected bm19 mice were harvested on day +6 and +10 . The organs were homogenized and plated in triplicate on BHI media petri dishes. Cultures were incubated for $18 \mathrm{~h}$ and colony counts were determined to evaluate organ clearance. As shown in Figure 2, TCR $V_{\beta} 9 / 12$ depleted bm19 mice are capable of mounting a cell-mediated immune response against $L$. monocytogenes in a manner that is comparable to both saline and isotype treated controls. These findings indicate that despite removing two distinct TCR $V_{\beta}$ families from these bm19 mice, which account for approximately $12 \%$ of the $\mathrm{T}$ cell repertoire, the overall cell-mediated immune system is still intact and fully functional. 


\section{DISCUSSION}

In this paper, we clearly show that the in vivo depletion of either $\mathrm{TCR} \mathrm{V}_{\beta} 9^{+}$or $\mathrm{V}_{\beta} 12^{+} \mathrm{T}$ cell populations from naïve bm19 mice prolongs the survival of $\mathrm{B} 6$ skin allografts. We report that B6 skin allografts transplanted onto bm19 mice remain intact for 31 days, 18 days longer than saline or isotype controls, when TCR $\mathrm{V}_{\beta} 9^{+}$cells have been removed. Likewise, depletion of $\mathrm{TCR} \mathrm{V}_{\beta} 12^{+}$cells prolongs $\mathrm{B} 6$ skin allograft survival to 22 days, 9 days beyond saline or isotype controls. When TCR $\mathrm{V}_{\beta} 9^{+}$and $\mathrm{V}_{\beta} 12^{+}$families are removed simultaneously there is a dramatic increase in B6 skin allograft survival, extending graft viability to 36 days post transplantation, a $>2.5$-fold increase in B6 allograft survival. These results demonstrate that both $\mathrm{TCR} \mathrm{V}_{\beta}$ families $\left(\mathrm{V}_{\beta} 9 / 12\right)$ are not only key players in the B6 allograft recognition and rejection by bm19 CTLs, but most interestingly, $\mathrm{V}_{\beta} 9 / 12$ act in a synergistic manner.

Our initial study (Frankenberry et al, submitted for publication) demonstrates that although five distinct TCR $\mathrm{V}_{\beta}$ families, $\mathrm{V}_{\beta} 8.1 / 8.2, \mathrm{~V}_{\beta} 9, \mathrm{~V}_{\beta} 10, \mathrm{~V}_{\beta} 12$ and $\mathrm{V}_{\beta} 14$, exhibit preferential expansion when bm19 splenocytes were stimulated in vitro with the irradiated splenocytes from the parental B6 strain, only CD8 ${ }^{+} \mathrm{TCR}_{\beta} 9$ and $\mathrm{V}_{\beta} 12 \mathrm{CTL}$ effectors showed cytolytic activity against $\mathrm{H}-2 \mathrm{~K}^{\mathrm{b}}$-bearing target cells. It is possible that the remaining TCR $\mathrm{V}_{\beta}$ families, $\mathrm{V}_{\beta} 8.1 / 8.2, \mathrm{~V}_{\beta} 10$, and $\mathrm{V}_{\beta} 14$, are directly responsible for the B6 skin allograft rejection seen in this study, despite minimal cytolytic activity in vitro. To address this possibility, future studies of B6 skin allograft survival, when transplanted onto female bm19 mice, will include two-color flow cytometry analysis of both $\mathrm{CD}^{+}$and $\mathrm{CD}^{+} \mathrm{TCR}_{\beta}$ splenocytes at specific time points (days $+10,+15,+20$, 
+25 and +30 ) to evaluate the in vivo expansion of $\mathrm{TCR}_{\beta}{ }^{+}$cells that may be actively involved in transplant rejection. In addition, B6 skin allografts, at time points throughout the acute rejection phase, will be removed, encased in paraffin wax, sectioned and analyzed by two-color flow cytometric staining. Thus allowing for direct identification of those $\mathrm{CD}^{+}$or $\mathrm{CD} 8^{+} \mathrm{T}$ cells infiltrating the allograft.

An alternative explanation for the delayed rejection of the B6 skin allografts can be explained by indirect allorecognition of the $\mathrm{H}-2 \mathrm{~K}^{\mathrm{b}}$ single amino acid difference $\left(\mathrm{Ass}^{80}\right.$ $\rightarrow$ Thr) when presented in the context of recipient-derived antigen-presenting cells (APCs). It has been documented that donor-derived extracellular antigens are internalized by recipient APCs and subsequently processed and presented in the antigenbinding cleft of both major histocompatibility complex (MHC) class I and class II molecules, thus allowing for presentation to either $\mathrm{CD} 4^{+}$or $\mathrm{CD} 8^{+} \mathrm{T}$ cells $(32,33)$. Unlike the direct pathway, which employs a high proportion of $\mathrm{T}$ cells recognizing the allogeneic MHC molecule (1 out of 200), the proportion of T cells involved in the indirect pathway is comparable to the recognition of nominal antigens (1 out of 100,000) (34). That indirect allorecognition plays a role in the rejection of B6 skin allografts is possible, owing to the observation that the allogeneic peptides presented via the indirect pathway can be derived from donor MHC class I, MHC class II or minor histocompatibility antigens (34). Indirect allorecognition in our bm19 mouse model would be further restricted to peptides derived from the donor class $\mathrm{I} H-2 \mathrm{~K}^{\mathrm{b}}$ single amino acid difference $\left(\mathrm{Asn}^{80} \rightarrow \mathrm{Thr}\right.$ ); since this is the only disparity between the bm19 mouse and the parental strain B6. Thus the combination of these observations, lower numbers of $\mathrm{T}$ cells 
involved in the indirect pathway and the restriction of peptide sequences derived from the donor $\mathrm{H}-2 \mathrm{~K}^{\mathrm{b}}$ molecule, could explain the delay in $\mathrm{B} 6$ skin allograft rejection.

The role of direct versus indirect allorecognition in transplant immunology has been extensively studied and is dependent on several factors; the tissue/organ being transplanted, the experimental model and the phase of rejection (35). For example, donor MHC class I is necessary for pancreatic islet cell rejection, but not heart rejection $(36,37)$. The acute rejection phase in murine skin allograft experiments is dominated by direct allorecognition, with $90 \%$ of the recipient $\mathrm{T}$ cells recognizing the donor MHC molecule and $10 \%$ of recipient $\mathrm{T}$ cells responding to donor-derived $\mathrm{MHC}$ peptide presented by donor APCs (38). However, studies involving MHC class I-deficient mice that reject skin allografts from MHC class II-deficient mice have demonstrated that $\mathrm{CD}^{+} \mathrm{T}$ cells were capable of recognizing donor-derived antigens presented in the context of recipient MHC class II on APCs through indirect allorecognition (39). Both of these observations occur in the early phase of acute rejection and it has been speculated that the blockade of the dominant mechanism of allograft rejection, the direct pathway, may allow the indirect pathway to contribute more prominently in the activation of allospecific T cells (40).

In our bm19 anti-B6 skin allograft survival model, we selectively depleted the TCR $V_{\beta} 9^{+}$and $V_{\beta} 12^{+} T$ cell populations by successive injections (i.p.) of mAbs specific for each TCR $V_{\beta}$ family. One drawback to this model is that we deplete both $C D 8^{+}$and $\mathrm{CD}^{+} \mathrm{T}$ cells bearing the $\mathrm{V}_{\beta} 9$ and $\mathrm{V}_{\beta} 12$ TCR. It is possible that engagement of the TCRspecific $\mathrm{mAb}$ without complimentary engagement of the CD4 co-receptor inactivated $\mathrm{CD}^{+}$TCR $\mathrm{V}_{\beta} 9^{+}$and $\mathrm{V}_{\beta} 12^{+} \mathrm{T}$ cells and influence the activation of less dominant alloreactive $\mathrm{CD} 8^{+} \mathrm{CTLs}, \mathrm{CD} 4^{+} \mathrm{T}_{\mathrm{H}}$ cells or APCs. It has been shown that patients treated 
with $\mathrm{T}$ cell depleting therapy exhibited decreased $\mathrm{CD}^{+} \mathrm{T}$ cell lymphoproliferative responses and reduced induction of early activation markers, CD69, CD25 and HLA-DR, after in vitro stimulation (41). This group also demonstrates that $\mathrm{CD} 4^{+} \mathrm{T}$ cell depleted populations have decreased IL-2 production and that attempts to increase $\mathrm{T}$ cell proliferation and CD69 cell surface expression by adding exogenous IL-2 fail (41). Therefore, depletion of $\mathrm{CD}^{+}$TCR $\mathrm{V}_{\beta} 9^{+}$and $\mathrm{V}_{\beta} 12^{+}$cells in vivo may result in defective/decreased $\mathrm{T}_{\mathrm{H}}$ cell IL-2 production for activated $\mathrm{CD} 8^{+} \mathrm{T}$ cells.

Likewise, the interaction between CD28 on T cells and B7.1 and B7.2 on APCs provides co-stimulatory signaling to $\mathrm{T}$ cells that initiate cytokine production and cell proliferation (42). Resting APCs express low levels of B7.1 and B7.2 on the cell surface and require stimulation via IL-2, interleukin-4 (IL-4), lipopolysaccaride or signaling through the MHC class II molecule for up-regulation $(43,44)$. IL-4-depleted mice challenged with allogeneic skin grafts demonstrated prolonged graft survival and a reduction in IL-2, IL-4 and interferon- $\gamma$ (IFN- $\gamma$ ) production (45). The authors suggest that the lack of IL-4 leaves T cells unactivated but functional, a phenomenon seen when B7 molecule interactions are prevented (46). Thus, depleting $\mathrm{CD}^{+}\left(\mathrm{T}_{\mathrm{H}} 2\right)$ cells in vivo could have disrupted the production of IL-4 and IL-2, both important stimuli for APC upregulation of B7.1 and B7.2, and consequently caused a reduction in CTL activation and function.

An important finding in this paper is that the selective in vivo depletion of two distinct TCR $\mathrm{V}_{\beta}$ families, which account for approximately $12 \%$ of the available $\mathrm{T}$ cell repertoire, does not inhibit L. monocytogenes organ clearance in these bm19 mice, suggesting that the cell-mediated immune system is still intact and functional. Although 
it has been established that TCR $\gamma \delta$-bearing T cells contribute to the host defense during the early stage of L. monocytogenes infection $(47,48)$, recent studies implicate perforindependent cytolysis and IFN- $\gamma$ production from $\mathrm{CD} 8^{+} \mathrm{T}$ cells as active components of the protective immunity against L. monocytogenes $(49,50)$. Interestingly, Harty and coworkers (50) demonstrate that in perforin-deficient mice there is a 5 -fold reduction in the per-cell protective capacity of $L$. monocytogenes antigen specific memory $\mathrm{CD} 8^{+} \mathrm{T}$ cells and that this deficiency in antilisterial immunity can be overcome by increasing the number of memory $\mathrm{CD} 8^{+} \mathrm{T}$ cells through repeated vaccinations. Although the $\mathrm{V}_{\beta} 9 / 12^{+} \mathrm{T}$ cell populations are depleted in this study, the remaining $\mathrm{CD}^{+} \mathrm{T}$ cells are capable of mounting an immunological response that is comparable to that of controls.

This is the first paper, to our knowledge, that addresses 1) the synergistic involvement of two distinct TCR $V_{\beta}$ families in transplant immunology, 2) the enhanced survival of allogeneic B6 skin grafts following the in vivo depletion of multiple TCR $\mathrm{V}_{\beta}$ families and 3) the ability of bm19 mice to mount a cell-mediated immune response against $L$. monocytogenes after the selective in vivo removal of $\mathrm{V}_{\beta} 9 / 12^{+}$CTLs. These observations are important to our understanding of transplant immunology and further our knowledge in devising methods by which we can alleviate the use of nonspecific immunosuppressive agents in the post transplantation setting. Theoretically, we can decrease patient morbidity, increase patient quality of life and decrease hospitalization time, secondary to opportunistic infections and carcinoma development, by selectively removing only those $\mathrm{T}$ cell populations actively participating in allograft rejection. 


\section{Table I}

Selective in vivo depletion of TCR $V_{\beta} 9^{+}, V_{\beta} 12^{+}$and $V_{\beta} 9 / 12^{+}$lymphocytes

\begin{tabular}{ccccccc} 
Day & $\begin{array}{c}\text { anti-HemA } \\
\mathrm{V}_{\beta} 9\end{array}$ & $\mathrm{~V}_{\beta} 9$ & $\begin{array}{c}\text { anti-HemA } \\
\mathrm{V}_{\beta} 12\end{array}$ & $\mathrm{~V}_{\beta} 12$ & $\begin{array}{c}\text { Anti-HemA } \\
\mathrm{V}_{\beta} 9 / 12\end{array}$ & $\mathrm{~V}_{\beta} 9 / 12$ \\
\hline Untreated & $5.3 \pm 0.62$ & $5.5 \pm 0.57$ & $6.4 \pm 0.46$ & $6.2 \pm 0.66$ & $11.5 \pm 0.52$ & $11.7 \pm 0.71$ \\
+3 & $5.4 \pm 0.57$ & $0.09 \pm 0.02$ & $6.0 \pm 0.08$ & $0.03 \pm 0.02$ & $11.3 \pm 0.26$ & $0.12 \pm 0.08$ \\
+7 & $5.7 \pm 0.45$ & $0.38 \pm 0.06$ & $6.5 \pm 0.79$ & $0.29 \pm 0.04$ & $12.2 \pm 0.51$ & $0.65 \pm 0.01$ \\
+14 & $5.4 \pm 0.62$ & $0.35 \pm 0.10$ & $6.5 \pm 0.48$ & $0.20 \pm 0.06$ & $11.8 \pm 0.91$ & $0.73 \pm 0.13$ \\
+21 & N.D. & $0.60 \pm 0.14$ & N.D. & $0.10 \pm 0.03$ & N.D. & $0.40 \pm 0.10$ \\
+24 & N.D. & $0.30 \pm 0.15$ & N.D. & $0.12 \pm 0.04$ & N.D. & $0.46 \pm 0.18$ \\
+28 & N.D. & $0.41 \pm 0.12$ & N.D. & $0.24 \pm 0.14$ & N.D. & $0.61 \pm 0.15$ \\
+35 & N.D. & $0.51 \pm 0.12$ & N.D. & $0.46 \pm 0.29$ & N.D. & $0.88 \pm 0.10$ \\
\hline
\end{tabular}

Individual bm19 female mice were given three i.p. injections (day $-3,0$ and +3 ) of $500 \mu \mathrm{g}$

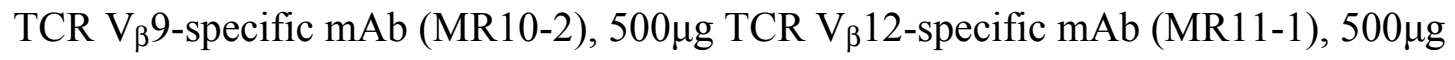
TCR $V_{\beta} 9$ - and $750 \mu$ g TCR $V_{\beta} 12$-specific $m A b$ or $500 \mu$ g anti-HemA mAb. All mAb are $\operatorname{IgG1}$, thus the anti-HemA mAb serves as the isotype control for TCR $\mathrm{V}_{\beta} 12$-specific $\mathrm{mAb}$.

Values are represented as the percent $\mathrm{CD} 8^{+} \mathrm{TCR} \mathrm{V}_{\beta}{ }^{+}$lymphocytes $\pm \mathrm{SD}$ from five separate bm19 female mice.

N.D. $=$ not determined 
FIGURES AND FIGURE LEGENDS

Fig. 1 Depletion of $V_{\beta} 9^{+}, V_{\beta} 12^{+}$and $V_{\beta} 9 / 12^{+} T$ cells in vivo significantly enhances the survival of B6 skin allografts transplanted onto bm19 mice.

Female bm19 mice (n=8 per group) were injected (i.p.) with $500 \mu$ g of anti-TCR $V_{\beta} 9$ $\mathrm{mAb}[\mathrm{MR} 10-2](\mathrm{O}), 500 \mu \mathrm{g}$ of anti-TCR $\mathrm{V}_{\beta} 12 \mathrm{mAb}$ [MR11-1] ( $\left.\square\right), 500 \mu \mathrm{g}$ of anti-TCR $\mathrm{V}_{\beta} 9 \mathrm{mAb}[\mathrm{MR} 10-2]$ and $750 \mu \mathrm{g}$ of anti-TCR $\mathrm{V}_{\beta} 12$ [MR11-1] $(\nabla)$ or $500 \mu \mathrm{g}$ anti-HemA $\mathrm{mAb}(\boldsymbol{\square})$ on days $-3,0,+3$, and +21 . 8mm skin samples from B6 and bm19 donors were transferred to bm19 recipients on day 0 as described in the Materials and Methods section. Saline treated female bm19 mice receiving only B6 grafts $(\boldsymbol{\nabla})$ acted as our positive control while saline treated female bm19 mice receiving only bm19 grafts $(\bullet)$ acted as our negative control. Graft survival was determined by visual inspection and caliper measurements on day 7 and reassessed every two days. 


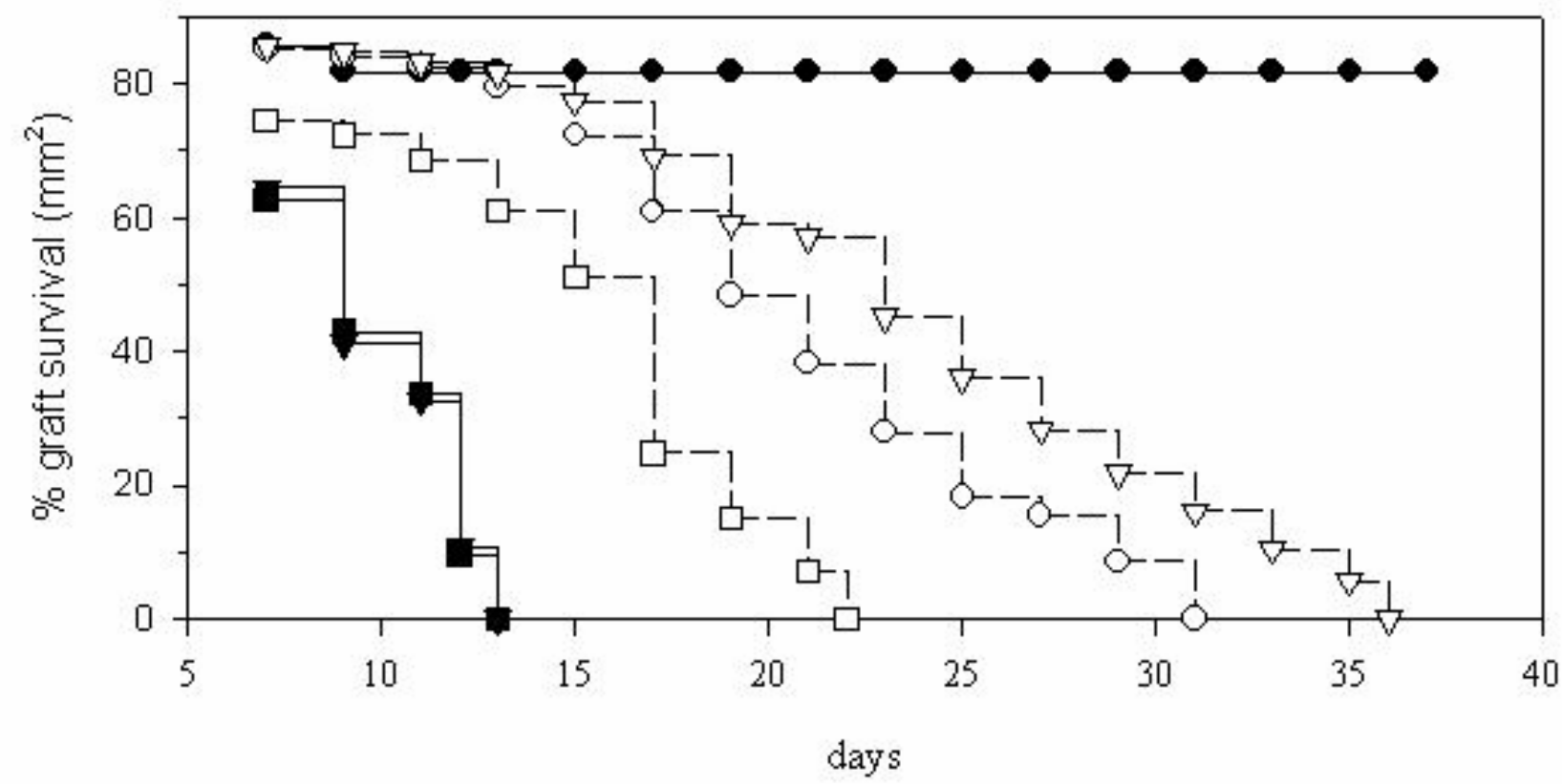

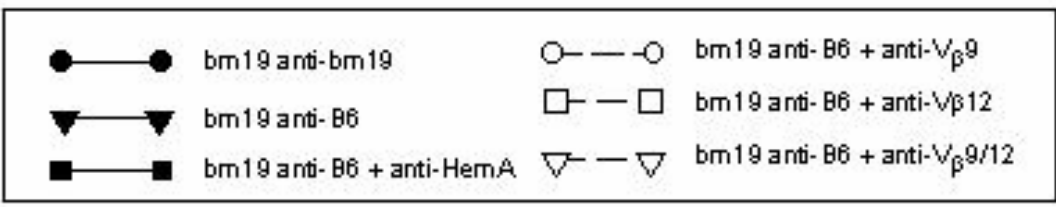


Fig. 2 The selective removal of $T C R \mathrm{~V}_{\beta} 9 / 12^{+} \mathrm{T}$ cells in vivo does not affect the cellmediated immune response.

Female bm19 mice (n=8 per group) were injected (i.p.) with 1 X PBS (A), $500 \mu \mathrm{g}$ anti-HemA mAb (B), or $500 \mu \mathrm{g}$ of anti-TCR $\mathrm{V}_{\beta} 9 \mathrm{mAb}$ [MR10-2] and $750 \mu \mathrm{g}$ of anti-TCR $\mathrm{V}_{\beta} 12$ [MR11-1] (C) on days $-3,0$, and +3 . L. monocytogenes $\left(1 \mathrm{X} 10^{6} \mathrm{CFU}\right)$ was injected (i.p.) on day +3 . Livers $(\Delta)$ and spleens $(\mathrm{O})$ were harvested on day +6 (filled symbols) and +10 (open symbols), homogenized on a Brinkmann Homogenizer and plated in triplicate on BHI media petri dishes by an Autoplate 4000 (Spiral Biotech, Norwood, MA). Cultures were incubated for $18 \mathrm{~h}$ and counted using a CASBA 4 (Spiral Biotech, Norwood, MA) colony counter. 


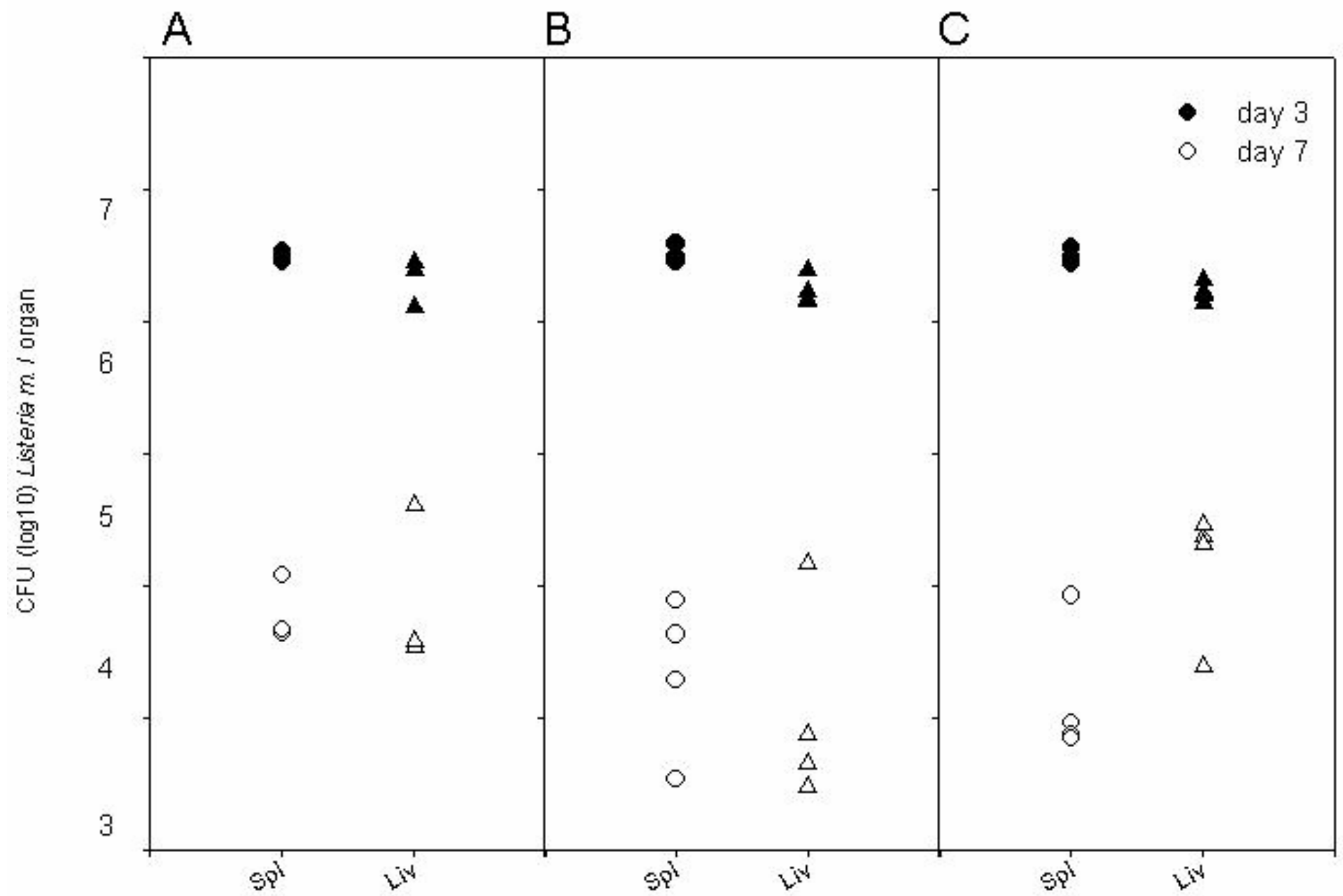




\section{REFERENCES}

1. d'Ivernois, C., M. Dupon, J. F. Dartigues, L. Potaux, M. Aparicio, and J. Y. Lacut. 1991. Decreased incidence of infection after renal transplantation with the use of cyclosporine. Eur.J Clin.Microbiol.Infect.Dis. 10:911-916.

2. Jamil, B., K. Nicholls, G. J. Becker, and R. G. Walker. 1999. Impact of acute rejection therapy on infections and malignancies in renal transplant recipients. Transplantation 68:1597-1603.

3. Penn, I. 1991. The changing pattern of posttransplant malignancies. Transplant.Proc. 23:1101-1103.

4. Sheil, A. G., A. P. Disney, T. H. Mathew, B. E. Livingston, and A. M. Keogh. 1997. Lymphoma incidence, cyclosporine, and the evolution and major impact of malignancy following organ transplantation. Transplant.Proc. 29:825-827.

5. Penn, I. 1996. Cancers in cyclosporine-treated vs azathioprine-treated patients. Transplant.Proc. 28:876-878.

6. Rubin, R. H., J. S. Wolfson, A. B. Cosimi, and N. E. Tolkoff-Rubin. 1981. Infection in the renal transplant recipient. Am.J Med. 70:405-411.

7. Hagerty, J. A., J. Ortiz, D. Reich, and C. Manzarbeitia. 2003. Fungal infections in solid organ transplant patients. Surg.Infect.(Larchmt.) 4:263-271. 
8. Hirose, R. and F. Vincenti. 1999. Review of transplantation--1999. Clin.Transpl.295315.

9. Oberholzer, J., F. Triponez, R. Mage, E. Andereggen, L. Buhler, N. Cretin, B. Fournier, C. Goumaz, J. Lou, J. Philippe, and P. Morel. 2000. Human islet transplantation: lessons from 13 autologous and 13 allogeneic transplantations. Transplantation 69:1115-1123.

10. Tachopoulou, O. A., D. P. Vogt, J. M. Henderson, M. Baker, and T. F. Keys. 2003. Hepatic abscess after liver transplantation: 1990-2000. Transplantation 75:79-83.

11. Hariharan, S., C. P. Johnson, B. A. Bresnahan, S. E. Taranto, M. J. McIntosh, and D. Stablein. 2000. Improved graft survival after renal transplantation in the United States, 1988 to 1996. N.Engl.J Med. 342:605-612.

12. U.S.Depatment of Health and Human Resources. 2003 Annual Report: The U.S. Organ Procurement and Transplantation Network and The Scientific Registry of Transplant Recipients. 2003.

13. Hariharan, S., M. A. McBride, L. E. Bennett, and E. P. Cohen. 1997. Risk factors for renal allograft survival from older cadaver donors. Transplantation 64:1748-1754.

14. Adu, D., P. Cockwell, N. J. Ives, J. Shaw, and K. Wheatley. 2003. Interleukin-2 receptor monoclonal antibodies in renal transplantation: meta-analysis of randomised trials. BMJ 326:789. 
15. Lietz, K., R. John, A. Beniaminovitz, E. M. Burke, N. Suciu-Foca, D. M. Mancini, N. M. Edwards, and S. Itescu. 2003. Interleukin-2 receptor blockade in cardiac transplantation: influence of HLA-DR locus incompatibility on treatment efficacy. Transplantation 75:781-787.

16. Tzakis, A. G., T. Kato, S. Nishida, D. M. Levi, P. Tryphonopoulos, J. R. Madariaga, W. De Faria, J. R. Nery, A. Regev, R. Vianna, J. Miller, V. Esquenazi, D. Weppler, and P. Ruiz. 2003. Alemtuzumab (Campath-1H) combined with tacrolimus in intestinal and multivisceral transplantation. Transplantation 75:1512-1517.

17. Kimura, T., T. Hasegawa, H. Nakai, T. Azuma, N. Usui, T. Sasaki, and A. Okada. 2003. FTY720 reduces T-cell recruitment into murine intestinal allograft and prevents activation of graft-infiltrating cells. Transplantation 75:1469-1474.

18. Chiba, K., Y. Yanagawa, H. Kataoka, T. Kawaguchi, M. Ohtsuki, and Y. Hoshino. 1999. FTY720, a novel immunosuppressant, induces sequestration of circulating lymphocytes by acceleration of lymphocyte homing. Transplant.Proc. 31:1230-1233.

19. Yanagawa, Y., K. Sugahara, H. Kataoka, T. Kawaguchi, Y. Masubuchi, and K. Chiba. 1998. FTY720, a novel immunosuppressant, induces sequestration of circulating mature lymphocytes by acceleration of lymphocyte homing in rats. II. FTY720 prolongs skin allograft survival by decreasing $\mathrm{T}$ cell infiltration into grafts but not cytokine production in vivo. J Immunol. 160:5493-5499. 
20. Koppi, T., D. J. Munster, L. Brown, K. P. MacDonald, and D. N. Hart. 2003. CMRF44 antibody-mediated depletion of activated human dendridic cells: a potential means for improving allograft survival. Transplantation 75:1723-1730.

21. Horig, H., A. C. Young, N. J. Papadopoulos, T. P. DiLorenzo, and S. G. Nathenson. 1999. Binding of longer peptides to the $\mathrm{H}-2 \mathrm{~K}^{\mathrm{b}}$ heterodimer is restricted to peptides extended at their $\mathrm{C}$ terminus: refinement of the inherent $\mathrm{MHC}$ class I peptide binding criteria. J Immunol. 163:4434-4441.

22. Saito, N. G., H. C. Chang, and Y. Paterson. 1999. Recognition of an MHC class Irestricted antigenic peptide can be modulated by para-substitution of its buried tyrosine residues in a TCR-specific manner. J Immunol. 162:5998-6008.

23. Sheil, J. M., S. E. Shepherd, G. F. Klimo, and Y. Paterson. 1992. Identification of an autologous insulin $\mathrm{B}$ chain peptide as a target antigen for $\mathrm{H}-2 \mathrm{~K}^{\mathrm{b}}$-restricted cytotoxic T lymphocytes. J Exp.Med. 175:545-552.

24. Wang, L., M. Elliott, and T. Elliott. 1999. Conditional stability of the HemA protein (glutamyl-tRNA reductase) regulates heme biosynthesis in Salmonella typhimurium. J.Bacteriol. 181:1211-1219.

25. Behlke, M. A., H. S. Chou, K. Huppi, and D. Y. Loh. 1986. Murine T-cell receptor mutants with deletions of $\beta$-chain variable region genes. Proc.Natl.Acad.Sci.U.S.A $83: 767-771$.

26. Melvold, R. W., H. I. Kohn, and G. R. Dunn. 1982. History and genealogy of the $\mathrm{H}-2 \mathrm{~K}^{\mathrm{b}}$ mutants from the C57BL/6Kh colony. Immunogenetics 15:177-185. 
27. Ledbetter, J. A., R. V. Rouse, H. S. Micklem, and L. A. Herzenberg. 1980. T cell subsets defined by expression of Lyt-1,2,3 and Thy-1 antigens. Two-parameter immunofluorescence and cytotoxicity analysis with monoclonal antibodies modifies current views. J Exp.Med. 152:280-295.

28. Watanabe-Ohnishi, R., D. E. Low, A. McGeer, D. L. Stevens, P. M. Schlievert, D. Newton, B. Schwartz, B. Kreiswirth, and M. Kotb. 1995. Selective depletion of $V_{\beta^{-}}$ bearing $\mathrm{T}$ cells in patients with severe invasive group A streptococcal infections and streptococcal toxic shock syndrome. Ontario Streptococcal Study Project. J Infect.Dis. 171:74-84.

29. Goss, J. A., M. A. Alexander-Miller, J. Gorka, M. W. Flye, J. M. Connolly, and T. H. Hansen. 1993. Specific prolongation of allograft survival by a T-cell-receptor-derived peptide. Proc.Natl.Acad.Sci.U.S.A 90:9872-9876.

30. Billingham, R. E. 2004. Free Skin Grafting in Mammals. In Transplantation of Tissues and Cells. R. E. Billingham and W. K. Silvers, eds. Wistar Institute Press, Philadelphia, pp. 1-29.

31. Steinmuller, D. 2004. Skin Grafting. In Methods in Enzymology. G. Di Sabato, J. J. Langone, and H. Van Vunakis, eds. Academic Press, San Diego, p. 20.

32. Lechler, R., W. F. Ng, and R. M. Steinman. 2001. Dendritic cells in transplantation-friend or foe? Immunity. 14:357-368. 
33. Rodriguez, A., A. Regnault, M. Kleijmeer, P. Ricciardi-Castagnoli, and S. Amigorena. 1999. Selective transport of internalized antigens to the cytosol for MHC class I presentation in dendritic cells. Nat.Cell Biol. 1:362-368.

34. Liu, Z., A. I. Colovai, S. Tugulea, E. F. Reed, P. E. Harris, A. Maffei, E. R. Molajoni, F. Gargano, R. Cortesini, M. A. Hardy, and N. Suciu-Foca. 1997. Mapping of dominant HLA-DR determinants recognized via the indirect pathway. Transplant.Proc. 29:1014-1015.

35. Illigens, B. M., A. Yamada, E. V. Fedoseyeva, N. Anosova, F. Boisgerault, A. Valujskikh, P. S. Heeger, M. H. Sayegh, B. Boehm, and G. Benichou. 2002. The relative contribution of direct and indirect antigen recognition pathways to the alloresponse and graft rejection depends upon the nature of the transplant. Hum.Immunol. 63:912-925.

36. Campos, L., A. Naji, B. C. Deli, J. H. Kern, J. I. Kim, C. F. Barker, and J. F. Markmann. 1995. Survival of MHC-deficient mouse heterotopic cardiac allografts. Transplantation 59:187-191.

37. Markmann, J. F., H. Bassiri, N. M. Desai, J. S. Odorico, J. I. Kim, B. H. Koller, O. Smithies, and C. F. Barker. 1992. Indefinite survival of MHC class I-deficient murine pancreatic islet allografts. Transplantation 54:1085-1089.

38. Benichou, G., A. Valujskikh, and P. S. Heeger. 1999. Contributions of direct and indirect $\mathrm{T}$ cell alloreactivity during allograft rejection in mice. J Immunol. 162:352358. 
39. Auchincloss, H., Jr., R. Lee, S. Shea, J. S. Markowitz, M. J. Grusby, and L. H. Glimcher. 1993. The role of "indirect" recognition in initiating rejection of skin grafts from major histocompatibility complex class II-deficient mice. Proc.Natl.Acad.Sci.U.S.A 90:3373-3377.

40. Morelli, A. E. and A. W. Thomson. 2003. Dendritic cells: regulators of alloimmunity and opportunities for tolerance induction. Immunol.Rev. 196:125-146.

41. Heitger, A., P. Winklehner, P. Obexer, J. Eder, C. Zelle-Rieser, G. Kropshofer, M. Thurnher, and W. Holter. 2002. Defective T-helper cell function after T-celldepleting therapy affecting naive and memory populations. Blood 99:4053-4062.

42. Turka, L. A., P. S. Linsley, H. Lin, W. Brady, J. M. Leiden, R. Q. Wei, M. L. Gibson, X. G. Zheng, S. Myrdal, D. Gordon, and . 1992. T-cell activation by the $\mathrm{CD} 28$ ligand $\mathrm{B} 7$ is required for cardiac allograft rejection in vivo. Proc.Natl.Acad.Sci.U.S.A 89:11102-11105.

43. Nabavi, N., G. J. Freeman, A. Gault, D. Godfrey, L. M. Nadler, and L. H. Glimcher. 1992. Signalling through the MHC class II cytoplasmic domain is required for antigen presentation and induces B7 expression. Nature 360:266-268.

44. Valle, A., J. P. Aubry, I. Durand, and J. Banchereau. 1991. IL-4 and IL-2 upregulate the expression of antigen $\mathrm{B} 7$, the $\mathrm{B}$ cell counterstructure to $\mathrm{T}$ cell CD28: an amplification mechanism for T-B cell interactions. Int.Immunol. 3:229-235.

45. Bagley, J., T. Sawada, Y. Wu, and J. Iacomini. 2000. A critical role for IL-4 in activating alloreactive CD4 T cells. Nat.Immunol. 1:257-261. 
46. Perez, V. L., L. Van Parijs, A. Biuckians, X. X. Zheng, T. B. Strom, and A. K. Abbas. 1997. Induction of peripheral $\mathrm{T}$ cell tolerance in vivo requires CTLA-4 engagement. Immunity. 6:411-417.

47. Eto, M., Y. Yoshikai, Y. Nishimura, K. Hiromatsu, T. Maeda, K. Nomoto, Y. Y. Kong, R. T. Kubo, J. Kumazawa, and K. Nomoto. 1994. Inhibition of allograft rejection by anti-T-cell receptor- $\alpha \beta$ monoclonal antibodies preserving resistance to bacterial infection. Immunology 81:198-204.

48. Matsuzaki, G., H. Yamada, K. Kishihara, Y. Yoshikai, and K. Nomoto. 2002. Mechanism of murine ${\mathrm{V} \gamma 1^{+}}_{\gamma} \delta \mathrm{T}$ cell-mediated innate immune response against Listeria monocytogenes infection. Eur.J Immunol. 32:928-935.

49. Berg, R. E., C. J. Cordes, and J. Forman. 2002. Contribution of CD8+ T cells to innate immunity: IFN- $\gamma$ secretion induced by IL-12 and IL-18. Eur.J Immunol. $32: 2807-2816$.

50. Messingham, K. A., V. P. Badovinac, and J. T. Harty. 2003. Deficient anti-listerial immunity in the absence of perforin can be restored by increasing memory $\mathrm{CD}^{+} \mathrm{T}$ cell numbers. J Immunol. 171:4254-4262. 
CHAPTER 6

GENERAL DISCUSSION 


\section{DISCUSSION}

This dissertation has been divided into two sections, Part I includes the antigenspecific response of Clone B6.H-4.1c to the horse cyt $c$ peptide sequence, p41-49, in the context of two separate class I MHC molecules, $\mathrm{H}-2 \mathrm{~K}^{\mathrm{b}}$ and $\mathrm{H}-2 \mathrm{D}^{\mathrm{b}}$, and Part II involves the allospecific recognition of the parental strain, B6, class I MHC/peptide complex by the $\mathrm{H}-2 \mathrm{~K}^{\mathrm{bm} 19}$ mutant mouse.

\section{Part I - Chapters 2 and 3}

The concept of "self $\mathrm{MHC}$ restriction" requires that a $\mathrm{CD}^{+} \mathrm{CTL}$ respond to a short peptide of 8-10 AA residues, presented in the context of a single self class I MHC molecule (1-5). More recently, this tenet of immunology has been reevaluated by the discovery of several peptides that not only bind to multiple class I MHC molecules, but are recognized by CTL clones (6-14).

To further characterize the dual-restricted recognition of CTL clones, we analyzed the ability of horse cyt $c$ p41-49 [G-Q-A-P-G-F-T-Y-T] to bind and stabilize both H-2K and $\mathrm{H}-2 \mathrm{D}^{\mathrm{b}}$ molecules and assessed the cytolytic reactivity of Clone B6.H-4.1c for $\mathrm{H}-2 \mathrm{~K}^{\mathrm{b}} / \mathrm{cyt} c \mathrm{p} 41-49$ and $\mathrm{H}-2 \mathrm{D}^{\mathrm{b}} / \mathrm{cyt} c \mathrm{p} 41-49$ complexes. In Chapter 2, we show that horse cyt $c$ p41-49 is recognized by Clone B6.H-4.1c when presented in the context of both $\mathrm{K}^{\mathrm{b}}$ and $\mathrm{D}^{\mathrm{b}}$ and requires comparable peptide concentrations, $\sim 4 \mathrm{nM}$ and $\sim 2 \mathrm{nM}$ respectively, to elicit cytolysis. Although horse cyt $c$ p41-49 lacks the complete peptide-

binding motif for either $\mathrm{H}-2 \mathrm{~K}^{\mathrm{b}}$ or $\mathrm{H}-2 \mathrm{D}^{\mathrm{b}}$, this peptide does contain a dominant anchor residue plus two weak anchor residues for $\mathrm{K}^{\mathrm{b}}$-binding and a single strong anchor residue 
plus three weak anchor residues for $\mathrm{D}^{\mathrm{b}}$-binding, and stabilizes both class I MHC molecules (15). Furthermore, H-2K $/$ cyt $c$ p 41-49 and H-2D $/$ cyt $c$ p41-49 complexes reach a steady state at 60 min when RMA-S cells were incubated at $37^{\circ} \mathrm{C}$, demonstrating that horse cyt $c$ p41-49 is presented in the context of both class I molecules. We also show that the introduction of a competitor peptide, MI B chain p7-15, cause significant increases $\left(>30\right.$-fold for $\mathrm{H}-2 \mathrm{~K}^{\mathrm{b}}$ and $>100$-fold for $\left.\mathrm{H}-2 \mathrm{D}^{\mathrm{b}}\right)$ in the horse cyt $c$ p41-49 peptide concentration required for Clone B6.H-4.1c recognition.

Computer-generated molecular models for horse cyt $c$ p41-49 bound to the H-K and $\mathrm{H}-2 \mathrm{D}^{\mathrm{b}}$ were constructed to determine peptide configuration and reveal that the central peptide region bulged distally, away from the peptide-binding groove, for both MHC/peptide complexes. These models also demonstrate that the combination of Pro $^{44}$-Gly ${ }^{45}$ confer a type II $\beta$ bend in the peptide configuration that may be required not only for $\mathrm{K}^{\mathrm{b}}$ - and $\mathrm{D}^{\mathrm{b}}$-binding, as previously predicted (16-18), but also Clone B6.H-4.1c recognition. Our molecular models facilitate the examination of MHC-peptide interactions and show that cyt $c$ p41-49 utilizes peptide residues $\mathrm{Gln}^{42}$, $\mathrm{Pro}^{44}$, Tyr ${ }^{48}$ and $\mathrm{Thr}^{49}$ bind to $\mathrm{H}-2 \mathrm{~K}^{\mathrm{b}}\left(\mathrm{Pro}^{42}, \mathrm{Phe}^{46}\right.$ and $\mathrm{Thr}^{47}$ are predicted anchor residues for $\mathrm{H}-2 \mathrm{~K}^{\mathrm{b}}$ ) and $\mathrm{Gly}^{41}, \mathrm{Gln}^{42}, \mathrm{Tyr}^{48}$ and $\mathrm{Thr}^{49}$ bind to $\mathrm{H}-2 \mathrm{D}^{\mathrm{b}}\left(\mathrm{Gln}^{42}, \mathrm{Phe}^{46}, \mathrm{Thr}^{47}\right.$ and $\mathrm{Tyr}^{48}$ are predicted anchor residues for $\mathrm{H}-2 \mathrm{D}^{\mathrm{b}}$ ). To evaluate potential $\mathrm{H}-2 \mathrm{~K}^{\mathrm{b}} / \mathrm{cyt} c \mathrm{p} 41-49$ and $\mathrm{H}-2 \mathrm{D}^{\mathrm{b}} / \mathrm{cyt} c$ p41-49 residues that interact with the TCR of Clone B6.H-4.1c, our models were analyzed for solvent-accessible residues using a $1.4 \AA$ probe (19). The solvent exposed R-groups of Pro ${ }^{44}$ and $\mathrm{Phe}^{46}$ contribute the majority of $\mathrm{H}-2 \mathrm{~K} / \mathrm{cyt} c \mathrm{p} 41-49$ surfaceaccessible contact residues. Similarly, the solvent exposed R-groups of Pro ${ }^{44}$ and Phe ${ }^{46}$, with minor contributions by the R-group of $\mathrm{Tyr}^{48}$ contribute the potential $\mathrm{H}-2 \mathrm{D}^{\mathrm{b}} / \mathrm{cyt} c$ 
p41-49 surface-accessible contact residues. Based on these observations, we hypothesize that the Pro ${ }^{44}-\mathrm{Gly}^{45}$ peptide sequence is critical for both horse cyt $c$ p41-49 stabilization of both $\mathrm{H}-2 \mathrm{~K}^{\mathrm{b}}$ and $\mathrm{H}-2 \mathrm{D}^{\mathrm{b}}$ and the dual-restricted recognition of Clone B6.H-4.1c.

To address the above proposal, we synthesized peptide analogues of horse cyt $c$ p41-49 that contain single Ala substitutions at $\mathrm{Pro}^{44}$ or Gly ${ }^{45}$, designated p41-49/44A and p41-49/45A, and determined $\mathrm{K}^{\mathrm{b}}$ - and $\mathrm{D}^{\mathrm{b}}$-stabilization and assessed the cytolytic activity of Clone B6.H-4.1c for both analogues. In Chapter 3, we show that Clone B6.H-4.1c CTLs recognizes analogue $\mathrm{p} 41-49 / 45 \mathrm{~A}$, but not analogue $\mathrm{p} 41-49 / 44 \mathrm{~A}$, when presented by $\mathrm{K}^{\mathrm{b}}$ - and $\mathrm{D}^{\mathrm{b}}$-expressing target cells. RMA-S stabilization analysis reveals that both analogues $\mathrm{p} 41-49 / 44 \mathrm{~A}$ and $\mathrm{p} 41-49 / 45 \mathrm{~A}$ stabilize $\mathrm{H}-2 \mathrm{~K}^{\mathrm{b}}$ and $\mathrm{H}-2 \mathrm{D}^{\mathrm{b}}$ molecules, but p41-49/45A exhibits increased $H-2 K^{b}$ steady states and rapidly dissociates from $H-2 D^{b}$ when compared to native horse cyt $c$ peptide. We demonstrate that Clone B6.H-4.1c recognition of $\mathrm{H}-2 \mathrm{~K}^{\mathrm{b}} / \mathrm{p} 41-49 / 45 \mathrm{~A}$ and $\mathrm{H}-2 \mathrm{D}^{\mathrm{b}} / \mathrm{p} 41-49 / 45 \mathrm{~A}$ requires significantly higher concentrations, $>30$-fold and $>30$-fold, respectively. We also show that the introduction of a competitor peptide, MI B chain p7-15 or analogue p41-49/44A, causes significant increases in the native horse cyt $c$ p41-49 and analogue p41-49/45A peptide concentration required for optimal target cell lysis. These peptide competition assays clearly reveal that the TCR of Clone B6.H-4.1c is capable of distinguishing minute changes in the MHC/peptide conformation caused by the G45A and P44A substitution. To better define peptide configuration changes that disrupt Clone B6.H-4.1c recognition, we constructed $\mathrm{H}-2 \mathrm{~K}^{\mathrm{b}}$ and $\mathrm{H}-2 \mathrm{D}^{\mathrm{b}}$ molecular models with native horse cyt $c$ p41-49, analogue $\mathrm{p} 41-49 / 44 \mathrm{~A}$ and analogue $\mathrm{p} 41-49 / 45 \mathrm{~A}$ presented in the peptide-binding groove. These models for $\mathrm{H}-2 \mathrm{~K}^{\mathrm{b}}$ demonstrate $\mathrm{C}$-terminus carbon backbone shifts at $\mathrm{Thr}^{49}$ and 
rotation of the aromatic ring of $\mathrm{Phe}^{46}$ for both analogue $\mathrm{p} 41-49 / 44 \mathrm{~A}$ and analogue $\mathrm{p} 41$ 49/45A. The H-2 $\mathrm{D}^{\mathrm{b}}$ molecular models show only minor carbon backbone shifts and small but distinguishable rotation of the $\mathrm{Phe}^{46}$ aromatic ring compared to native horse cyt $c$ p41-49. These observations indicate that the absence of $\operatorname{Pro}^{44}$ and the rotation of the aromatic ring of Phe ${ }^{46}$ directly affects the cytolytic response of Clone B6.H-4.1c for $\mathrm{H}-2^{\mathrm{b}} / \mathrm{cyt} c \mathrm{p} 41-49$ and $\mathrm{H}-2^{\mathrm{b}} / \mathrm{p} 41-49 / 45 \mathrm{~A}$ complexes. In addition, the rapid dissociation of p41-49/45A may also decrease the responsiveness of Clone B6.H-4.1c. Our conclusions from the studies outlined in Chapters 2 and 3, are that the solvent-exposed R groups of both $\mathrm{Pro}^{44}$ and $\mathrm{Phe}^{46}$ are important for Clone B6.H-4.1c recognition of $\mathrm{H}-2 \mathrm{~K}^{\mathrm{b}} / \mathrm{cyt} c$ p41-49 and $\mathrm{H}-2 \mathrm{D}^{\mathrm{b}} / \mathrm{cyt} c \mathrm{p} 41-49$ complexes. We propose that the imino group of $\mathrm{Pro}^{44}$ is necessary for recognition by Clone B6.H-4.1c and the orientation of the $\mathrm{Phe}^{46}$ aromatic ring, caused by $\mathrm{Gly}^{45}$, is essential for full CTL responsiveness.

To address this hypothesis, future studies are directed at single Ala substitution of $\mathrm{Phe}^{46}$ at peptide position, p6. Although our molecular models show that cyt $c$ p41-49 utilizes peptide residues $\mathrm{Gln}^{42}, \mathrm{Pro}^{44}, \mathrm{Tyr}^{48}$ and $\mathrm{Thr}^{49}$ to bind to $\mathrm{H}-2 \mathrm{~K}^{\mathrm{b}}$ and $\mathrm{Gly}^{41}, \mathrm{Gln}^{42}$, $\mathrm{Tyr}^{48}$ and $\mathrm{Thr}^{49}$ to bind to $\mathrm{H}-2 \mathrm{D}^{\mathrm{b}}$, although $\mathrm{Phe}^{46}$ is predicted to be an anchor residue for both class I H-2 ${ }^{\mathrm{b}}$ molecules. The loss of the aromatic side chain, contributed by $\mathrm{Phe}^{46}$, may prohibit both $\mathrm{K}^{\mathrm{b}}$ - and $\mathrm{D}^{\mathrm{b}}$-binding or may disrupt Clone B6.H-4.1c recognition of these MHC/peptide complexes, as seen with the p41-49/44A analogue. As noted in Chapter 3, several other investigators have reported that the substitution of a single AA in the peptide sequence alter the MHC/peptide conformation, without affecting the number of complexes available to the TCR, and influence CTL recognition (20-23). 
In addition to standard RMA-S stabilization analysis, combinatorial peptide libraries, peptide competition assays and computer-generated molecular models that examine native peptides and their analogues, the crystal structures of the trimolecular complexes, $\mathrm{H}-2 \mathrm{~K}^{\mathrm{b}} / \mathrm{cyt} c \mathrm{p} 41-49$ and $\mathrm{H}-2 \mathrm{D}^{\mathrm{b}} / \mathrm{cyt} c \mathrm{p} 41-49$, with the TCR of Clone B6.H-4.1 c, would provide invaluable insight into the TCR/MHC/peptide interaction. The generation of these crystal structures would provide direct analysis of the interactions between the native cyt $c$ p41-49 peptide and the TCR. In this manner we could identify, and prove or disprove our hypothesis, the peptide residues essential for Clone B6.H-4.1c recognition. Likewise, crystal structures of the $\mathrm{H}-2 \mathrm{~K}^{\mathrm{b}} / \mathrm{p} 41-49 / 45 \mathrm{~A}$ and $\mathrm{H}-2 \mathrm{D}^{\mathrm{b}} / \mathrm{p} 41-49 / 45 \mathrm{~A}$ with the TCR of Clone B6.H-4.1c would provide comparative analysis and insight into the flexibility of TCR interactions.

The demonstration that the horse cyt $c$ peptide is presented efficiently to cloned CTLs by the $\mathrm{H}-2 \mathrm{~K}^{\mathrm{b}}, \mathrm{H}-2 \mathrm{D}^{\mathrm{b}}$ and $\mathrm{H}-2 \mathrm{~K}^{\mathrm{bm} 1}$ molecules (18) prompted the analysis of horse cyt $c$ p41-49 recognition by Clone B6.H-4.1c when presented in the context of the H-2 $\mathrm{K}^{\mathrm{b}}$ mutant strains, $\mathrm{H}-2 \mathrm{~K}^{\mathrm{bm} 19}$ and $\mathrm{H}-2 \mathrm{~K}^{\mathrm{bm} 11}(24,25)$. The $\mathrm{H}-2 \mathrm{~K}^{\mathrm{bm} 11}$ mutant strain varies from the parental strain, B6, by an AA substitution on the $\alpha 1$ helix at position $77, \mathrm{Asp}^{77} \rightarrow \mathrm{Ser}$, and an AA substitution on the $\alpha 1$ helix at position $80, \operatorname{Thr}^{80} \rightarrow$ Asn $(24,25)$. Similarly, the $\mathrm{H}-2 \mathrm{~K}^{\mathrm{bm} 19}$ mutant strain varies from the parental strain, B6, by an AA substitution on the $\alpha 1$ helix at position $80, \mathrm{Thr}^{80} \rightarrow$ Asn $(24,25)$. Initial ${ }^{51} \mathrm{Cr}$-release analysis reveal that $\mathrm{H}-2 \mathrm{~K}^{\mathrm{bm} 19} / \mathrm{cyt} c \mathrm{p} 41-49$ and $\mathrm{H}-2 \mathrm{~K}^{\mathrm{bm} 11} / \mathrm{cyt} c \mathrm{p} 41-49$ complexes are recognized by Clone B6.H-4.1c (data not shown). Although we have not determined the stability of these MHC/peptide complexes or whether the minimal peptide concentrations required for lysis are comparable with $\mathrm{H}-2 \mathrm{~K} / \mathrm{cyt} c \mathrm{p} 41-49$, the demonstration that a cloned CTL can 
recognize the same peptide in the context of five disparate class I MHC molecules is indeed a novel finding.

\section{Part II - Chapters 4 and 5}

Acute allograft rejection and graft-versus-host disease (GVHD) are mediated by alloreactive $\mathrm{T}$ lymphocytes that respond to foreign class I MHC molecules on the engrafted donor tissue (26-30). Studies by Grandea II and Bevan (31) using the class I $\mathrm{H}-2 \mathrm{~K}^{\mathrm{b}}$ transgenic mouse mutant, $\mathrm{H}-2 \mathrm{~K}^{\mathrm{b}, \mathrm{E} 65}\left(\mathrm{Gln}^{65} \rightarrow \mathrm{Glu}\right)$, show that a single AA disparity in the $\mathrm{H}-2 \mathrm{~K}^{\mathrm{b}}$ molecule generated a strong CTL response. These $\mathrm{H}-2 \mathrm{~K}^{\mathrm{b}, \mathrm{E} 65}$ alloreactive CTLs exhibit cytolytic activity against the wild-type $\mathrm{K}^{\mathrm{b}}$-expressing target cell line and several mutant target cells, including $\mathrm{H}-2 \mathrm{~K}^{\mathrm{b}, \mathrm{D} 65}\left(\mathrm{Gln}^{65} \rightarrow \mathrm{Asp}\right), \mathrm{H}-2 \mathrm{~K}^{\mathrm{b}, \mathrm{R} 65}$ $\left(\mathrm{Gln}^{65} \rightarrow \mathrm{Arg}\right)$ and $\mathrm{H}-2 \mathrm{~K}^{\mathrm{b}, \mathrm{V} 65}\left(\mathrm{Gln}^{65} \rightarrow \mathrm{Val}\right)$. These findings suggest that cross-reactive CTLs may have a higher affinity for nonconserved AA changes (31). Connolly and coworkers $(32,33)$ evaluated the $L^{d}$-specific CTL response of the $L^{d}$-loss mutant, $d m 2$, and implicate the TCR $V_{\beta} 8^{+}$alloreactive CTLs as effectors of the $L^{d}$-specific response. They show that by adding the anti- $\mathrm{V}_{\beta} 8 \mathrm{mAb}, \mathrm{F} 23.1$, to ${ }^{51} \mathrm{Cr}$-release assays the $\mathrm{H}-2 \mathrm{~L}^{\mathrm{d}}$ specific CTL response is diminished by approximately $80 \%(32,33)$. They also demonstrate that the depletion of $\mathrm{V}_{\beta} 8^{+}$CTLs in vivo prolongs the survival of $\mathrm{L}^{\mathrm{d}}$-disparate skin grafts by two-fold, indicating that the $\mathrm{CD}^{+} \mathrm{V}_{\beta} 8^{+}$effectors contribute to the allospecific response $(32,33)$.

In this dissertation, we have selected the B6-derived mutant mouse strain, bm19 $(24,25)$, that has a single AA substitution at position $80\left(\mathrm{Thr}^{80} \rightarrow\right.$ Asn) of the $\mathrm{H}-2 \mathrm{~K}^{\mathrm{b}}$ molecule, and evaluated specific bm19 $\mathrm{CD}^{+} \mathrm{TCR} \mathrm{V}_{\beta}$ families involved in the 
alloreactive response to $\mathrm{H}-2 \mathrm{~K}^{\mathrm{b}}$. As shown in Chapter 4, we initially identify five distinct $\mathrm{CD}^{+} \mathrm{V}_{\beta}$ families $-\mathrm{V}_{\beta} 8.1 / 8.2,9,10,12$ and 14 - that preferentially expand in both shortand long-term bm19 anti-B6 MLCs. We show that although the $\mathrm{V}_{\beta} 8.1 / 8.2,10$ and 14 families exhibit preferential expansion in vitro, enrichment for these $\mathrm{CD}^{+} \mathrm{V}_{\beta}$ families fails to increase the cytolytic activity of $3^{\circ}$ bm19 anti-B6 CTLs, and reduces the lytic unit (LU) value dramatically ( $\sim 0 \mathrm{LU}, \sim 5 \mathrm{LU}$ and $\sim 0 \mathrm{LU}$ versus $\sim 20 \mathrm{LU}$ for untreated bm19 anti-B6 effectors). Depleting the $\mathrm{V}_{\beta} 8.1 / 8.2,10$ and 14 families also causes minimal reductions in the cytolytic activity of $3^{\circ}$ bm19 anti-B6 CTLs, but these tertiary MLCs retain $\mathrm{H}-2 \mathrm{~K}^{\mathrm{b}}$-specific alloreactivity comparable to untreated bm19 anti-B6 CTLs. The selective removal of $\mathrm{V}_{\beta} 9^{+}$or $\mathrm{V}_{\beta} 12^{+}$families reduces the alloreactive responsiveness of $3^{\circ}$ bm19 anti-B6 effectors ( $\sim 2$ and $\sim 7 \mathrm{LU}$, respectively), while enrichment for $\mathrm{V}_{\beta} 9^{+}$or $\mathrm{V}_{\beta} 12^{+}$ families causes a minimal reduction in the cytolytic activity of $3^{\circ}$ bm19 anti-B6 CTLs ( $\sim 20 \mathrm{LU}$ and $\sim 15 \mathrm{LU}$, respectively). By depleting both the $\mathrm{V}_{\beta} 9^{+}$and $\mathrm{V}_{\beta} 12^{+}\left(\mathrm{V}_{\beta} 9 / 12^{+}\right)$ $\mathrm{CTL}$ effectors we abrogate the alloreactive response to $\mathrm{H}-2 \mathrm{~K}^{\mathrm{b}}$ while enriching for both the $\mathrm{CD} 8^{+} \mathrm{V}_{\beta} 9 / 12^{+} \mathrm{T}$ cells enhances the lytic capacity of $3^{\circ} \mathrm{bm} 19$ anti-B6 CTLs ( $\sim 100 \mathrm{LU}$ versus $\sim 20 \mathrm{LU}$ ) for the allogeneic target, S.B6. These observations demonstrate that $\mathrm{V}_{\beta} 9^{+}$and $\mathrm{V}_{\beta} 12^{+}$effectors contribute synergistically to the alloreactive response against $\mathrm{K}^{\mathrm{b}}$-expressing target cells. Chapter 4 also documents the preservation of both antigenand allospecific recognition in vitro despite the selective depletion of $\mathrm{CD}^{+} \mathrm{V}_{\beta} 9 / 12^{+} \mathrm{T}$ cells, approximately $12 \%$ of the bm19 $\mathrm{T}$ cell repertoire. We show that the removal of the $\mathrm{V}_{\beta} 9 / 12^{+}$families has no effect on bm19 anti-B6 proliferation or recognition of the VSV-8 peptide (viral), the MI B chain p7-15 peptide (self) or to the unrelated $\mathrm{H}-2^{\mathrm{d}}$ alloantigen. Based on these findings, we hypothesize that the in vivo depletion of $\mathrm{V}_{\beta} 9 / 12^{+} \mathrm{T}$ cells 
would prevent B6 skin allograft rejection without compromising the entire immune system.

To address the above proposal, we selectively depleted the $\mathrm{V}_{\beta} 9^{+}, \mathrm{V}_{\beta} 12^{+}$, and $\mathrm{V}_{\beta} 9 / 12^{+} \mathrm{T}$ cells from female bm19 mice and evaluated the B6 skin allograft survival. In Chapter 5 , we demonstrate that selectively removing the $\mathrm{V}_{\beta} 9^{+} \mathrm{T}$ cell population prolongs B6 skin graft survival by 18 days when compared to the saline and isotype controls (31 days versus 13 days). Likewise, the in vivo depletion of $\mathrm{V}_{\beta} 12^{+} \mathrm{T}$ cells prolongs $\mathrm{B} 6$ skin allograft survival by 9 days beyond control mice (22 days versus 13 days). Most importantly, the depletion of both $\mathrm{TCR} \mathrm{V}_{\beta} 9 / 12^{+}$families simultaneously extends B6 skin graft survival to 36 days, a $>2.5$-fold increase in survival, thus supporting the in vitro evidence that both $\mathrm{TCR} \mathrm{V}_{\beta}$ families act synergistically in the alloreactive response to $\mathrm{H}-2 \mathrm{~K}^{\mathrm{b}}$. To show that the immune status of bm19 mice is intact, despite removing approximately $12 \%$ of the bm19 $\mathrm{T}$ cell repertoire, we infected $\mathrm{V}_{\beta} 9 / 12^{-}$bm19 mice with $L$. monocytogenes. Organ clearance is comparable in both saline control bm19 mice and those that are depleted of TCR $\mathrm{V}_{\beta} 9 / 12^{+} \mathrm{T}$ cells, thus indicating that the host immune system was functional. This dissertation is the first to demonstrate that alloreactive CTLs can act synergistically in their response to alloantigen and that selectively removing these CTLs can prolong allograft survival without compromising the host immune system. The findings in Chapters 4 and 5 suggest that although allograft survival is prolonged, other factors are involved in the final rejection of the B6 skin allograft. Therefore, we propose that those $\mathrm{TCR} \mathrm{V}_{\beta}$ families $\left(\mathrm{V}_{\beta} 8.1 / 8.2,10\right.$ and 14) that exhibit preferential in vitro expansion, but demonstrate minimal cytolytic activity, are responsible for the ultimate rejection of B6 skin allografts in our model system. 
To determine whether the $\mathrm{TCR} \mathrm{V}_{\beta} 8.1 / 8.2,10$ and 14 families are actively involved in bm19 anti-B6 rejection of B6 skin allografts, future studies will include twocolor flow cytometric analysis of both $\mathrm{CD}^{+}$and $\mathrm{CD} 8^{+} \mathrm{TCR} \mathrm{V}_{\beta}$ splenocytes, inguinal and brachial lymph nodes $(\mathrm{LN})$ at designated time points (i.e., days $+10,+15,+20,+25$ and +30 ) to evaluate the in vivo expansion of $\mathrm{V}_{\beta}^{+} \mathrm{T}$ cells following B6 skin transplantation. In addition, histological assessment of the B6 allograft with two-color staining will identify the $\mathrm{CD}^{+}$and $\mathrm{CD} 8^{+} \mathrm{T}$ cells infiltrating the transplant at the same time points as spleen and LN evaluations. This approach will allow both a direct and indirect characterization of the $\mathrm{T}$ cell populations active in the alloreactive response against $\mathrm{K}^{\mathrm{b}}$ expressing cells.

It is also possible that a $\mathrm{TCR} \mathrm{V}_{\beta}$ family, not detected by preferential in vitro expansion, is induced in vivo by the indirect allorecognition pathway. Although this would require that recipient APCs present a peptide, derived from the donor class I $\mathrm{H}-2 \mathrm{~K}^{\mathrm{b}}$, containing the single AA disparity $\left(\mathrm{Asn}^{80} \rightarrow \mathrm{Thr}\right)$, it has been reported that donor-derived extracellular antigens are internalized by recipient APCs, processed and presented in the context of both class I and class II MHCs $(34,35)$. Thus it is possible that the single AA disparity ( $\mathrm{Asn}^{80} \rightarrow \mathrm{Thr}$ ) of $\mathrm{H}-2 \mathrm{~K}^{\mathrm{b}}$ could be presented to either $\mathrm{CD} 4^{+}$ or $\mathrm{CD}^{+} \mathrm{T}$ cells. The proposed studies (above) would identify both $\mathrm{CD} 4^{+}$and $\mathrm{CD} 8^{+} \mathrm{T}$ cell expansion induced by either the direct or indirect allorecognition pathway, but would not differentiate between the two.

The demonstration, by Sheil and coworkers (36), that the $\mathrm{H}-2 \mathrm{~K}^{\mathrm{b}}$-restricted CTL response to VSV-infected $\mathrm{K}^{\mathrm{b}}$-expressing target cells is partially cross-reactive to the uninfected $\mathrm{H}-2 \mathrm{~K}^{\mathrm{bm} 8}$ mutant target cells and the observations described in Chapters 4 and 
5 prompted studies investigating the cross-reactive response of bm19 anti-B6 CTLs against the $\mathrm{H}-2 \mathrm{~K}^{\mathrm{b}}$ mutant strain, bm11. Preliminary analysis of the cytolytic activity of bm19 anti-B6 MLCs demonstrate that these bm19 CTLs exhibit cross-reactivity to the closely related $\mathrm{K}^{\mathrm{bm} 11}$-expressing target cells (data not shown). Although these studies are preliminary, it is tempting to speculate that the $\mathrm{TCR} \mathrm{V}_{\beta}$ families $\left(\mathrm{V}_{\beta} 8.1 / 8.2,10\right.$ and 14) that exhibited preferential in vitro expansion are involved in the cross-reactive response of bm19 anti-B6 effectors against S.bm11 targets. Future studies, involving $\mathrm{V}_{\beta} 8.1 / 8.2$, 10 and 14 depletion and enrichment for each $\mathrm{V}_{\beta}$ family both in vitro and in vivo, may reveal that while TCR $V_{\beta} 9 / 12^{+}$CTLs are critical for recognition of $H-2 K^{b}$, the remaining $\mathrm{V}_{\beta}$ families participate in cross-reactive recognition of $\mathrm{H}-2 \mathrm{~K}^{\mathrm{bm} 11}$.

\section{Leaps of Faith}

This dissertation is designed to bridge two seemingly different topics in immunology, antigen- and allospecific recognition. As described above, several CTL clones display dual-restricted recognition of a single peptide in the context of several class I MHC molecules. In the case of Clone B6.H-4.1c, recognition of horse cyt $c$ p41-49 occurs in the context of $\mathrm{H}-2 \mathrm{~K}^{\mathrm{b}}, \mathrm{H}-2 \mathrm{~K}^{\mathrm{bm} 1}, \mathrm{H}-2 \mathrm{~K}^{\mathrm{bm} 11}, \mathrm{H}-2 \mathrm{~K}^{\mathrm{bm} 19}$ and $\mathrm{H}-2 \mathrm{D}^{\mathrm{b}}$ and recognition of the analogue $\mathrm{p} 41-49 / 45 \mathrm{~A}$ occurs on $\mathrm{H}-2 \mathrm{~K}^{\mathrm{b}}$ - and $\mathrm{H}-2 \mathrm{D}^{\mathrm{b}}$-expressing targets. Likewise, although the peptide bound to $\mathrm{H}-2 \mathrm{~K}^{\mathrm{b}}$ is unknown, the alloreactive response of bm19 anti-B6 CTLs exhibit cross-reactivity against the closely related mutant, $\mathrm{K}^{\mathrm{bm} 11}$.

Wilson and coworkers $(37,38)$ reported that the CTL clone, Clone $2 \mathrm{C}$, recognizes the peptide dEV8 when presented by $\mathrm{H}-2 \mathrm{~K}^{\mathrm{b}}$ and $\mathrm{H}-2 \mathrm{~K}^{\mathrm{bm} 3}$ and also responds to SIYR when in the context of $\mathrm{H}-2 \mathrm{~K}^{\mathrm{b}}$. The primary basis for the dual-recognition observed for 
Clone B6.H-4.1c and Clone 2C may be that the MHC/peptide/TCR interaction has a high rate of degeneracy (or cross-reactivity). Studies analyzing the 2C, KB5-C20 and LC13 TCRs reveal conformational differences between unliganded and liganded TCRs (38-40). The CDR3 region demonstrates the main focus of conformational reorganization, with minimal change within the CDR1 and CDR2 loops. The variability of the $\mathrm{V} \alpha-\mathrm{V} \beta$ pairing and the flexibility of the CDR3 facilitates conformational changes in the TCR to accommodate the restrained MHC/peptide complex conformation $(41,42)$. Reiser and coworkers (40) demonstrate that some CDR3s can adopt at least two discrete conformational states, but only one of these states is able to bind to the $\mathrm{MHC} /$ peptide complex. Malissen and coworkers (43) performed a comparative analysis for CTL BM3.3 TCR in complex with two distinct peptides, pBMI and VSV-8, bound to $\mathrm{H}-2 \mathrm{~K}^{\mathrm{b}}$. Their results show that an Asn, at peptide position p6, of pBMI and a Gln, at peptide position p4, of VSV-8 constitute the critical contact positions for BM3.3 recognition. The cross-reactivity of the BM3.3 TCR is largely due to the flexibility of the CDR3, which facilitates contact with VSV-8 by the CDR3 $\alpha$ loop, thus compensating for the loss of CDR3 $\beta$ contacts (involved in the recognition of $\mathrm{pBMI}$ ). This study demonstrates how the flexibility of the CDR3 region may facilitate recognition despite variations in the available residue contacts. Likewise, Wilson and coworkers (44) demonstrate that in the alloreactive CTL Clone $2 \mathrm{C}$ the CDR3 $\beta$ interactions occur with the C-terminal half of the $H-2 L^{d}$ bound peptide, suggesting that the TCR contact with peptide strongly affects, in large part, the alloreactive response. Thus, the flexibility of the CDR3 region may account the cross-reactivity that is seen in both antigen-specific and allospecific CTLs and bridge the gap between these two fields of immunology. 


\section{REFERENCES}

1. Bevan, M. J. 1975. The major histocompatibility complex determines susceptibility to cytotoxic T cells directed against minor histocompatibility antigens. J Exp.Med. 142:1349-1364.

2. Bevan, M. J. 1977. Killer cells reactive to altered-self antigens can also be alloreactive. Proc.Natl.Acad.Sci.U.S.A 74:2094-2098.

3. Doherty, P. C. and R. M. Zinernagel. 1975. Capacity of sensitized thymus-derived lymphocytes to induce fatal lymphocytic choriomeningitis is restricted by the H-2 gene complex. J Immunol. 114:30-33.

4. Doherty, P. C. and R. M. Zinkernagel. 1975. Enhanced immunological surveillance in mice heterozygous at the H-2 gene complex. Nature 256:50-52.

5. Zinkernagel, R. M. and P. C. Doherty. 1997. The discovery of MHC restriction. Immunol.Today 18:14-17.

6. Fleischhauer, K., S. Tanzarella, H. J. Wallny, C. Bordignon, and C. Traversari. 1996. Multiple HLA-A alleles can present an immunodominant peptide of the human melanoma antigen Melan-A/MART-1 to a peptide-specific HLA-A*0201 ${ }^{+}$ cytotoxic T cell line. J Immunol. 157:787-797.

7. Johnson, R. P., A. Trocha, T. M. Buchanan, and B. D. Walker. 1992. Identification of overlapping HLA class I-restricted cytotoxic $\mathrm{T}$ cell epitopes in a conserved region of the human immunodeficiency virus type 1 envelope glycoprotein: 
definition of minimum epitopes and analysis of the effects of sequence variation. $J$ Exp.Med. 175:961-971.

8. Oldstone, M. B., A. Tishon, R. Geckeler, H. Lewicki, and J. L. Whitton. 1992. A common antiviral cytotoxic T-lymphocyte epitope for diverse major histocompatibility complex haplotypes: implications for vaccination. Proc.Natl.Acad.Sci.U.S.A 89:2752-2755.

9. Paradela, A., M. Garcia-Peydro, J. Vazquez, D. Rognan, and J. A. Lopez de Castro. 1998. The same natural ligand is involved in allorecognition of multiple HLA-B27 subtypes by a single $\mathrm{T}$ cell clone: role of peptide and the $\mathrm{MHC}$ molecule in alloreactivity. J Immunol. 161:5481-5490.

10. Rivoltini, L., D. J. Loftus, K. Barracchini, F. Arienti, A. Mazzocchi, W. E. Biddison, M. L. Salgaller, E. Appella, G. Parmiani, and F. M. Marincola. 1996. Binding and presentation of peptides derived from melanoma antigens MART-1 and glycoprotein-100 by HLA-A2 subtypes. Implications for peptide-based immunotherapy. J Immunol. 156:3882-3891.

11. Sheil, J. M., S. E. Shepherd, G. F. Klimo, and Y. Paterson. 1992. Identification of an autologous insulin $\mathrm{B}$ chain peptide as a target antigen for $\mathrm{H}-2 \mathrm{~K}^{\mathrm{b}}$-restricted cytotoxic T lymphocytes. J Exp.Med. 175:545-552.

12. Shirai, M., M. S. Vacchio, R. J. Hodes, and J. A. Berzofsky. 1993. Preferential V $\beta$ usage by cytotoxic T cells cross-reactive between two epitopes of HIV-1 gp160 and degenerate in class I MHC restriction. J Immunol. 151:2283-2295. 
13. Tallquist, M. D., A. J. Weaver, and L. R. Pease. 1998. Degenerate recognition of alloantigenic peptides on a positive-selecting class I molecule. J Immunol. 160:802809.

14. Threlkeld, S. C., P. A. Wentworth, S. A. Kalams, B. M. Wilkes, D. J. Ruhl, E. Keogh, J. Sidney, S. Southwood, B. D. Walker, and A. Sette. 1997. Degenerate and promiscuous recognition by CTL of peptides presented by the MHC class I A3-like superfamily: implications for vaccine development. J Immunol. 159:1648-1657.

15. Falk, K., O. Rotzschke, S. Stevanovic, G. Jung, and H. G. Rammensee. 1991. Allele-specific motifs revealed by sequencing of self-peptides eluted from MHC molecules. Nature 351:290-296.

16. Deres, K., T. N. Schumacher, K. H. Wiesmuller, S. Stevanovic, G. Greiner, G. Jung, and H. L. Ploegh. 1992. Preferred size of peptides that bind to H-2K $\mathrm{K}^{\mathrm{b}}$ is sequence dependent. Eur.J Immunol. 22:1603-1608.

17. Fremont, D. H., M. Matsumura, E. A. Stura, P. A. Peterson, and I. A. Wilson. 1992. Crystal structures of two viral peptides in complex with murine MHC class I H-2K . Science 257:919-927.

18. Sheil, J. M., T. D. Schell, S. E. Shepherd, G. F. Klimo, J. M. Kioschos, and Y. Paterson. 1994. Presentation of a horse cytochrome c peptide by multiple $\mathrm{H}-2^{\mathrm{b}}$ class I major histocompatibility complex (MHC) molecules to $\mathrm{C} 57 \mathrm{BL} / 6-$ and bm1derived cytotoxic T lymphocytes: presence of a single MHC anchor residue may confer efficient peptide-specific CTL recognition. Eur.J Immunol. 24:2141-2149. 
19. Ding, Y. H., K. J. Smith, D. N. Garboczi, U. Utz, W. E. Biddison, and D. C. Wiley. 1998. Two human $\mathrm{T}$ cell receptors bind in a similar diagonal mode to the HLA-A2/Tax peptide complex using different TCR amino acids. Immunity. 8:403411.

20. Brett, S. J., D. McKean, J. York-Jolley, and J. A. Berzofsky. 1989. Antigen presentation to specific $\mathrm{T}$ cells by Ia molecules selectively altered by site-directed mutagenesis. Int.Immunol. 1:130-140.

21. Krieger, J. I., R. W. Karr, H. M. Grey, W. Y. Yu, D. O'Sullivan, L. Batovsky, Z. L. Zheng, S. M. Colon, F. C. Gaeta, J. Sidney, and . 1991. Single amino acid changes in DR and antigen define residues critical for peptide-MHC binding and $\mathrm{T}$ cell recognition. J Immunol. 146:2331-2340.

22. McMichael, A. J., F. M. Gotch, J. Santos-Aguado, and J. L. Strominger. 1988. Effect of mutations and variations of HLA-A2 on recognition of a virus peptide epitope by cytotoxic T lymphocytes. Proc.Natl.Acad.Sci.U.S.A 85:9194-9198.

23. Peccoud, J., P. Dellabona, P. Allen, C. Benoist, and D. Mathis. 1990. Delineation of antigen contact residues on an MHC class II molecule. EMBO J 9:4215-4223.

24. Lewis, J., M. Foo, S. S. Geier, P. A. Kumar, S. G. Nathenson, and J. A. Bluestone. 1988. Cytotoxic T lymphocyte recognition of novel allodeterminants expressed on in vitro selected $\mathrm{H}-2 \mathrm{~K}^{\mathrm{b}}$ mutants. J Immunol. 141:728-735.

25. Melvold, R. W., H. I. Kohn, and G. R. Dunn. 1982. History and genealogy of the $\mathrm{H}-2 \mathrm{~K}^{\mathrm{b}}$ mutants from the $\mathrm{C} 57 \mathrm{BL} / 6 \mathrm{Kh}$ colony. Immunogenetics 15:177-185. 
26. Baker, M. S., X. Chen, A. R. Rotramel, J. J. Nelson, B. Lu, C. Gerard, Y. Kanwar, and D. B. Kaufman. 2003. Genetic deletion of chemokine receptor CXCR3 or antibody blockade of its ligand IP-10 modulates posttransplantation graft-site lymphocytic infiltrates and prolongs functional graft survival in pancreatic islet allograft recipients. Surgery 134:126-133.

27. Hancock, W. W., N. M. Thomson, and R. C. Atkins. 1983. Composition of interstitial cellular infiltrate identified by monoclonal antibodies in renal biopsies of rejecting human renal allografts. Transplantation 35:458-463.

28. Kalwak, K., D. Turkiewicz, M. Ussowicz, E. Gorczynska, J. Toporski, R. Ryczan, B. Rybka, D. Noworolska-Sauren, and A. Chybicka. 2003. Clinical value of the flow cytometric method for measuring lymphocyte subset activation: spontaneous activation of T-cell subpopulations is associated with acute GvHD. Transplant.Proc. 35:1559-1562.

29. Pefaur, J., R. Trivino, C. Navarrete, E. Oberhauser, M. Melys, I. Morales, P. Salinas, and A. Mocarquer. 2003. Clinical graft evolution of lymphocytes, polymorphonuclear cells, and antigen expression in tubular renal cells in the urine sediment of 20 renal allograft recipients. Transplant.Proc. 35:2500-2505.

30. Posselt, A. M., F. Vincenti, M. Bedolli, M. Lantz, J. P. Roberts, and R. Hirose. 2003. CD69 expression on peripheral CD8 T cells correlates with acute rejection in renal transplant recipients. Transplantation 76:190-195. 
31. Grandea, A. G., III and M. J. Bevan. 1993. A conservative mutation in a class I MHC molecule outside the peptide binding groove stimulates responses to self peptides. J Immunol. 151:3981-3987.

32. Goss, J. A., R. Pyo, M. W. Flye, J. M. Connolly, and T. H. Hansen. 1993. Major histocompatibility complex-specific prolongation of murine skin and cardiac allograft survival after in vivo depletion of $\mathrm{V}_{\beta}{ }^{+} \mathrm{T}$ cells. $J$ Exp.Med. 177:35-44.

33. Goss, J. A., M. A. Alexander-Miller, J. Gorka, M. W. Flye, J. M. Connolly, and T. H. Hansen. 1993. Specific prolongation of allograft survival by a T-cell-receptorderived peptide. Proc.Natl.Acad.Sci.U.S.A 90:9872-9876.

34. Lechler, R., W. F. Ng, and R. M. Steinman. 2001. Dendritic cells in transplantation-friend or foe? Immunity. 14:357-368.

35. Rodriguez, A., A. Regnault, M. Kleijmeer, P. Ricciardi-Castagnoli, and S. Amigorena. 1999. Selective transport of internalized antigens to the cytosol for MHC class I presentation in dendritic cells. Nat.Cell Biol. 1:362-368.

36. Sheil, J. M., M. J. Bevan, and L. Lefrancois. 1987. Characterization of dual-reactive $\mathrm{H}-2 \mathrm{~K}^{\mathrm{b}}$-restricted anti-vesicular stomatitus virus and alloreactive cytotoxic T cells. $J$ Immunol. 138:3654-3660.

37. Garcia, K. C., M. Degano, R. L. Stanfield, A. Brunmark, M. R. Jackson, P. A. Peterson, L. Teyton, and I. A. Wilson. 1996. An $\alpha \beta$ T cell receptor structure at 2.5 $\AA$ and its orientation in the TCR-MHC complex. Science 274:209-219. 
38. Garcia, K. C., M. Degano, L. R. Pease, M. Huang, P. A. Peterson, L. Teyton, and I. A. Wilson. 1998. Structural basis of plasticity in T cell receptor recognition of a self peptide-MHC antigen. Science 279:1166-1172.

39. Kjer-Nielsen, L., C. S. Clements, A. W. Purcell, A. G. Brooks, J. C. Whisstock, S. R. Burrows, J. McCluskey, and J. Rossjohn. 2003. A structural basis for the selection of dominant $\alpha \beta \mathrm{T}$ cell receptors in antiviral immunity. Immunity. 18:5364.

40. Reiser, J. B., C. Gregoire, C. Darnault, T. Mosser, A. Guimezanes, A. M. SchmittVerhulst, J. C. Fontecilla-Camps, G. Mazza, B. Malissen, and D. Housset. 2002. A $\mathrm{T}$ cell receptor CDR3 $\beta$ loop undergoes conformational changes of unprecedented magnitude upon binding to a peptide/MHC class I complex. Immunity. 16:345-354.

41. Boniface, J. J., Z. Reich, D. S. Lyons, and M. M. Davis. 1999. Thermodynamics of $\mathrm{T}$ cell receptor binding to peptide-MHC: evidence for a general mechanism of molecular scanning. Proc.Natl.Acad.Sci.U.S.A 96:11446-11451.

42. Willcox, B. E., G. F. Gao, J. R. Wyer, J. E. Ladbury, J. I. Bell, B. K. Jakobsen, and P. A. van der Merwe. 1999. TCR binding to peptide-MHC stabilizes a flexible recognition interface. Immunity. 10:357-365.

43. Reiser, J. B., C. Darnault, C. Gregoire, T. Mosser, G. Mazza, A. Kearney, P. A. van der Merwe, J. C. Fontecilla-Camps, D. Housset, and B. Malissen. 2003. CDR3 loop flexibility contributes to the degeneracy of TCR recognition. Nat.Immunol. 4:241247. 
44. Speir, J. A., J. Stevens, E. Joly, G. W. Butcher, and I. A. Wilson. 2001. Two different, highly exposed, bulged structures for an unusually long peptide bound to rat MHC class I RT1-Aa. Immunity. 14:81-92. 


\section{MARC ALAN FRANKENBERRY}

\section{MEDICAL EDUCATION:}

- MD (to be awarded May 2004)

West Virginia University School of Medicine

West Virginia University

Morgantown, WV 26506-9111

\section{GRADUATE EDUCATION:}

- PhD (to be awarded May 2004)

West Virginia University School of Medicine

Department of Microbiology, Immunology \& Cell Biology

West Virginia University

Morgantown, WV 26506-9111

\section{UNDERGRADUATE EDUCATION:}

- BS Biology major with a Biochemistry minor (May 1994)

Wheeling Jesuit College

Wheeling, WV 26003

Summa Cum Laude, 3.87 GPA

\section{WORK EXPERIENCE:}

- Area Coordinator, Wheeling Jesuit College (1992 - 1994)

$>$ My role as an Area Coordinator was to supervise the activities of six Resident Assistants (R.A.) within a co-ed dormitory consisting of 96 upper classmen full-time students. The R.A. staff and I provided extracurricular and wellness activities for each of the six halls. We were responsible for promoting a positive learning environment and assisting any individual needs that arose.

- Resident Assistant of International Students, Wheeling Jesuit College (Summer 1993)

$>$ A Resident Assistant (R.A.) of international students has the task of orienting foreign exchange students to the campus in general, campus rules and regulations and class scheduling. In addition, I was responsible for providing extracurricular activities for these students and organized several sessions devoted to improving their understanding and use of the English language.

- Upward Bound Program Resident Supervisor, Wheeling Jesuit College (Summer 1992)

> The Upward Bound Program is designed for high school juniors and seniors who excel in science and mathematics. This program encourages students to further their knowledge base in the basic 
sciences by providing honors classes at designated college campuses throughout the country. These students were selected based on high academic standing and low socioeconomic status. My role was to oversee the daily activities of these students and provide educational support as a tutor for many of their class assignments.

- Resident Assistant, Wheeling Jesuit College (1991 - 1992)

$>$ The role of a Resident Assistant (R.A.) is to provide a safe environment for extracurricular and scholastic achievements. As a R.A. of freshmen students I was responsible for conveying and enforcing the rules and regulations of Wheeling Jesuit College Campus Life. In addition, wellness activities were provided to meet the specific needs of the 22 students under my care.

\section{VOLUNTEER ACTIVITIES:}

- Student Health Volunteer, Shepherd College, WV (January, 2002)

$>$ A rural rotation in Family Medicine during the month of January placed me in the unique position of being a volunteer at the Student Health Care facilities at Shepherd College. As a medical student, I was introduced to the complex health issues of adolescent and young adult patients, including family planning, unplanned pregnancy, sexually transmitted diseases and date rape.

- MD/PhD Student Representative, WVU School of Medicine (1998 - 2001)

> The student representative for the MD/PhD program at WVU is responsible for scheduling formal presentations by fellow MD/PhD candidates, faculty members and guest lecturers. The student representative is also responsible for the transportation, lodging and evening entertainment of guest lecturers.

- Graduate Student Representative, Department of Microbiology \& Immunology, WVU School of Medicine (1997 - 2001)

> Similar to the role of MD/PhD student representative, the graduate student representative is responsible for the scheduling, transportation and lodging of guest lecturers. The Department of Microbiology \& Immunology permits the graduate student class to invite one lecturer per semester to visit the facilities and present research in their given field. In addition, the graduate student representative organizes and facilitates meetings with the departmental Chairperson in an open forum every semester (or privately if required) to address current graduate student concerns.

- Family Medicine Clinic, Shinnston, WV (Summer 1996)

$>$ The summer of 1996 was spent in a small rural Family Practice clinic in Shinnston, WV. While under the direct guidance of two physicians, I performed history and physical exams, formed a working assessment and plan and provided a formal presentation 
of their patients. This opportunity provided useful experience in patient care in the rural family health setting.

- Academic Resource Center, Wheeling Jesuit College (1992 - 1994)

$>$ The Academic Resource Center (ARC) provided freshmen and upper class students free tutorial services in multiple disciplines.

My role in the ARC was primarily as a biological sciences tutor, but also included biochemistry, physics and literature. Tutorial sessions were held for one hour with approximately $6-10$ students, with two sessions per week.

- Academic Life Committee, Wheeling Jesuit College (1992 - 1994)

$>$ The Academic Life Committee is dedicated to continuing the high academic standards of Wheeling Jesuit College. As part of this committee, I evaluated incoming student applications and assisted with defining student admission criteria. The committee was responsible for determining which students were granted admission to Wheeling Jesuit College. In addition, this committee served as the Academic Standards Committee, with emphasis on providing assistance to students with poor academic standing.

- Campus Ministry Retreat Leader, Wheeling Jesuit College (1991)

$>$ Wheeling Jesuit College provided spiritual outings through Campus Ministry. A Retreat Leader is responsible for organizing and presenting one topic of discussion that supports the general theme for each specific retreat. The Retreat Leader utilizes small group activities to further promote that topic within the allotted four hour time period.

\section{TEACHING APPOINTMENTS:}

- Problem-Based Learning Proctor for WVU School of Medicine and Dentistry (Fall and Spring semesters 2000 - 2001)

$>$ WVU School of Medicine and Dentistry participate in problembased learning activities involving $8-12$ students and one proctor. The proctor is responsible for establishing a clear, meaningful discussion on the topic at hand. For example, the sessions pertaining to HIV and AIDS deal with not only the route of infection, infectious agent, method of treatment and serious medical outcomes, but also the medical expense and psychosocial aspects of this devastating disease process.

- Undergraduate Research Mentorship (1995 - 2001)

$>$ As a graduate student in the Department of Microbiology \& Immunology, I was given the task of educating undergraduate and graduate students that rotated through my particular laboratory. This involved proper handling of potentially harmful radioactive and caustic materials, animal husbandry, sterile laboratory techniques, equipment use and maintenance and computer programming necessary for completing their rotation. 
- Graduate Laboratory Assistant (Fall semester 2000)

$>$ The Department of Microbiology \& Immunology requires each graduate student to participate as Laboratory Assistants for the School of Medicine and the School of Dentistry. This position entailed preparing the laboratory equipment, specimens and handouts, giving a formal presentation of the objectives, providing essential background information and grading all assignments for each specific laboratory session.

\section{SOCIETY MEMBERSHIPS:}

- American Medical Association

- Alpha Sigma Nu (National Jesuit Honor Society)

- PADI SCUBA Divers Association

\section{RESEARCH SUBMITTED AND IN PREPARATION:}

- "A Cloned CD8+ Cytotoxic T Cell Displays both $\mathrm{K}^{\mathrm{b}}$ - and $\mathrm{D}^{\mathrm{b}}$-Restricted Recognition of the Horse Cytochrome c Peptide, p41-49"

- "Dual H-2K - and H-2D $\mathrm{D}^{\mathrm{b}}$-Restricted Clonal CTL Recognition of a Horse Cytochrome c Peptide is Dependent on a Critical Pro-Gly Sequence"

- "Depletion of $\mathrm{V}_{\beta} 9^{+}$and $\mathrm{V}_{\beta} 12^{+} \mathrm{CTLs}$ in vitro abrogates the bm19 antiC57BL/6 alloreactive response without impairing antigen-specific CTL reactivity“

- "Depletion of $\mathrm{V}_{\beta} 9^{+}$and $\mathrm{V}_{\beta} 12^{+} \mathrm{T}$ cells in bm19 mutant mice enhances the survival of $\mathrm{C} 57 \mathrm{BL} / 6$ skin allografts without disrupting antigen-specific cellmediated immunity"

\section{CONFERENCES AND PROFESSIONAL LECTURES:}

- E. J. Van Liere Memorial Research Convocation, WVU School of Medicine Research Day

$>$ Ongoing research presentations from $1997-2000$

- Annual Mid-Atlantic Conference

> "In Vitro T-Cell Receptor $\mathrm{V}_{\beta}$ Depletion Abrogates Alloreactivity but not Antigen-specific Responses" Ocean City, MD (2000)

$>$ "T-Cell Receptor $\mathrm{V}_{\beta}$ Analysis of Alloreactive Cytotoxic TLymphocytes Responding to H-2K ${ }^{b}$ Differences" Harpers Ferry, WV (1999)

> "Alloreactive Cytotoxic T-Cells Utilize a Distinct Subset of T-Cell Receptor $V_{\beta}$ Families for Allorecognition" Hershey, PA (1998)

- $25^{\text {th }}$ Annual MD/PhD Conference

> "Activation of Alloreactive Cytotoxic T-Lymphocytes in Response to Distinct MHC Differences" Boulder, CO (1997) 


\section{HOBBIES AND INTERESTS:}

- Scuba diving, classical literature, hiking, cross-country racing $(5 \mathrm{~K})$, theatre, wine and jazz festivals and white-water rafting.

\section{HONORS AND AWARDS:}

- MD/PhD Scholarship, WVU School of Medicine (1995 - present)

- Gloriam Award for Leadership and Excellence, Wheeling Jesuit College $(1993$ - 1994)

- Laut Scholar, Wheeling Jesuit College (1991 - 1994)

- Dean's List, Wheeling Jesuit College (1990 - 1994)

- Presidential Scholarship, Wheeling Jesuit College (1990 - 1994)

\section{REFERENCES:}

- Letters of Reference File available upon request from:

West Virginia University School of Medicine

Office of Student Services, Charleston Campus

Charleston, WV 25304-1299

(304) 347-1319 / (877) 988-2427 